Марина Радєва, Анатолій Ткач, Вікторія Коломієць, Іван Рекун, Тамара Ткач, Ольга Золкіна

\title{
ТРАНСФОРМАЦІЙНІ ПРОЦЕСИ В ЕКОНОМІЦІ: ІНСТИТУЦІОНАЛЬНИЙ КОНТЕКСТ
}

Монографія 
УДК 330.837-044.922(477)(02.064)

ББК 65.010.11я91

T 65

Трансформаційні процеси в економіці: інституціональний контекст: монографія / М. Радєва, А. Ткач, В. Коломієць та ін. / за ред. М.М. Радєвої. Мелітополь: ТОВ «Колор Принт», 2018. 364 с. ISBN 978-966-2489-64-4. DOI : https://doi.org/10.32901/978-966-2489-64-4/2018.

\title{
DOI: https://doi.org/10.32901/978-966-2489-64-4/2018
}

\section{Рецензенти:}

ОстАШ Гжегож, проф., доктор хаб., проректор Жешувської політехніки ім. І. Лукасєвича

ГЕНДЕК Станіслав, доктор хаб. інж., проф. Жешувської політехніки, декан фракультету управління Жешувської політехніки ім. І. Лукасєвича

\author{
Рекомендовано до друку Вченою радою МІДМУ «КПУ» \\ (Протокол № 11 від 28 червня 2018 р.)
}

В монографрії аналізуються методологія інституціональних змін в економічних системах, сучасні напрями і перспективи інституціональних трансформацій економіки, корпоративної діяльності, людського капіталу та умови зміцнення економічної безпеки підприємств. Досліджуються психолого-педагогічні передумови формування інституціональної моделі освітнього простору особистості.

Книга розрахована на аспірантів, науковців, викладачів і усіх, хто цікавиться інституціоналізмом. 


\section{MICT}

\section{Передмова}

\section{РАЗДЕЛ 1. ИНСТИТУЦИОНАЛЬНАЯ ОСНОВА РАЗВИТИЯ ЭКОНОМИКИ (Радева М. Н.)}

1.1. Методология институционального анализа развития экономики 7

1.2. Институциональная динамика базовых институтов экономики... 28

1.3. Институционное обеспечение развития экономики............... 38

1.4. Институциональные изменения конкурентной среды трансформационной экономики............................ 47

1.5. Глобальная институционализация экономики.................... 62

РАЗДЕЛ $2 . \quad$ ИНСТИТУЦИОНАЛЬНЫЕ ЭКОНОМИЧЕСКИХ СИСТЕМ (ТКач А. А.)

2.1. Теоретические основы институциональных изменений в экономике................................................ $\quad 71$

2.2. Развитие концепций институциональных изменений............ 80

2.3. Механизмы институциональных изменений..................... 86

2.4. Институциональное проектирование в экономике................ 96

2.5. Институционализация прав собственности...................... 104

2.6. Изменение прав собственности............................. 117

2.7. Трансформация прав собственности в условиях 128

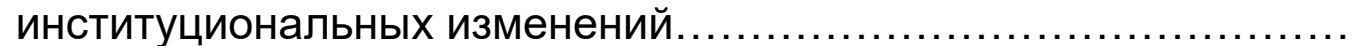

2.8. Изменения внешних эфффектов.............................. 136

РОЗДІЛ 3. ПРОЦЕСИ СТАНОВЛЕННЯ ЛЮДСЬКОГО КАПІТАЛУ В УМОВАХ ПЕРЕБУДОВИ ІНСТИТУЦІОНАЛЬНОГО СЕРЕДОВИЩА (Коломієць В. М. - п/p. 3.1 - 3.6; Золкіна О. В. - п/p. 3.7)

3.1. Інституціональна природа людського капіталу................... 141

3.2. Розвиток інституціональної системи людського капіталу.......... 148

3.3. Інституціональна структура людського капіталу.................. 158

3.4. Інвестиції в людський капітал як основа розвитку національної економіки................................................. 183

3.5. Формування інституту людського капіталу в Україні............... 199

3.6. Людський капітал як чинник конкурентоспроможності національної економіки..................................... 208

3.7. Вкладення в людський капітал - дієвий засіб підвищення його конкурентоспроможності..................................... 215

РОЗДІЛ 4. ІНСТИТУЦІОНАЛЬНА ТРАНСФОРМАЦІЯ ЕКОНОМІЧНОЇ БЕЗПЕКИ (Рекун І. І.)

4.1. Зміна інституціональної парадигми економічної безпеки......... 218

4.2. Розвиток форм економічної безпеки........................... 225

4.3. Формування нових моделей економічної безпеки підприємств.. 238

4.4. Інституціонально-економічні моделі поведінки підприємств...... 246

4.5. Розробка економіко-інформаційної системи економічної

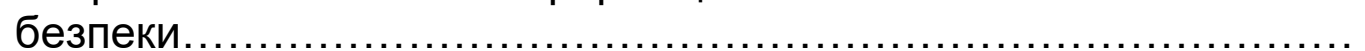


РОЗДІЛ 5. ФОРМУВАННЯ ІНСТИТУЦІОНАЛЬНОЇ МОДЕЛІ ОСВІТНЬОГО ПРОСТОРУ ОСОБИСТОСТІ (Ткач Т. В.)

5.1. Умови формування інституціональної моделі освітнього простору особистості..........................................

5.2. Процес становлення інституціональної моделі освітнього простору особистості.

5.3. Психологічні підходи до проектування в соціальних системах...

5.4. Компонентна структура проектування в соціальних системах....

5.5. Проектування освітнього простору особистістю (самопроектування).

ВИСНОВКИ

ЛІТЕРАТУРА

АННОТАЦИЯ.

SUMMARY...

АНОТАЦІЯ

ІМЕННИЙ ПОКАЗЧИК

\section{AUTHORS}

\section{Maryna Radieva}

Rector, Melitopol Institute of Public and Municipal Administration of the «Classic Private University» Classic Private University, Ukraine E-mail: ra_va@ukr.net ORCID: https://orcid.org/0000-0003-2288-3388

\section{Anatoliy Tkach}

Department of Economic Theory, Rzeszow University of Technology, Poland E-mail: tkach_aa@prz.edu.pl ORCID: https://orcid.org/0000-0002-7207-117X

\section{Viktoriia Kolomiiets}

Department of Finance and Economic Security, Dnipropetrovsk National University of Railway Transport named after Academician V. Lazaryan, Ukraine

E-mail: vik2005vik@meta.ua ORCID: https://orcid.org/0000-0003-3427-8986

\section{Ivan Rekun}

Department of Finance and Economic Security, Dnipropetrovsk National University of Railway Transport named after Academician V. Lazaryan, Ukraine

E-mail: docrekun@gmail.com

ORCID: https://orcid.org/0000-0002-3536-7369

\section{Tamara Tkach}

Department of psychology, Pereyaslav-Khmelnytskyi State Pedagogical University named after Hryhoriy Skovoroda, Ukraine

E-mail: tkachtam@gmail.com

ORCID: https://orcid.org/0000-0001-5290-5395

\section{Olga Zolkina}

E-mail:vik2005vik@meta.ua 


\section{ПЕРЕДМОВА}

Трансформаційні процеси в економіиі України можуть бути успішними лише за умови побудови циивілізованих інститутів. Нові інститути і інституиії створюють середовище, що сприяє розвитку бізнесу і праиі. До головних складових необхідних перетворень відносяться, пери за все, механізми інституиіональних змін в економіці на підставі специфікації прав власності, інституціональна трансформація корпоративного сектору економіки, розвиток людського капіталу, інституціональний розвиток економічної безпеки, формування інституціональної моделі освітнього простору.

Процес інституціональних перетворень досліджується як процес безперервних неформальних змін, що закріпляються в формальній інституціональній системі суспільства у вигляді відповідних норм поведінки і створення організацій, щуо контролюють їх дотримання. Інституціональні зміни - це перехід до нових економічних відносин, на основі розвитку прав власності.

Транснаціональний капітал, щзо домінує на світовому ринку, стирає економічні, політичні та культурні національні відмінності, формує сприятливу глобальну інфраструктуру, забезпечує розвиток краӥн, щчо утворюють «ядро» світової корпоративної економіки.

Створення інституиіональних передумов розвитку людського капіталу для примноження багатства $i$ потенціалу країни стає пріоритетом економічного розвитку. Людський капітал вважається найціннішим ресурсом краӥни, який створюе пери за все інтелектуальний потениіал держави, щьо визначає ї̈ позиції на світовому полі. Наявність зрілого людського капіталу обумовлює економічний потенціал краӥни та ї̈ стратегічне зростання.

Інституціональна трансформачія економічної безпеки розглядається як перелом сприйняття ролі і значення соціальних, політичних, економічних, 
військових чи релігійних інститутів, зміна способу мислення $і$ дї, заснованої на раціональності, що об'єднує безпеку з механізмами наказів і контролю. У сучасному плюралістичному і різноманітному світі потрібне мислення, яке здатне формулювати та усувати причини використання засобів сили, а на їх місие мають прийти політичні і моральні ресурси.

Сучасний стан освіти висвітлюється як прочес ї̈ перетворення $у$ подовжену протягом усього життя сферу діяльності людини, а здобутки людства у галузі освіти стали основою для формування складної соџіальної структури у вигляді освітнього простору. Провідною функціональною тенденцією освітнього простору є його розвиток у напрямі неперервності та всеосяжності, а його проектування зумовлене психологічними детермінантами, що супроводжують формування нового змісту, форм $i$ характеру освіти. Нові знання перетворюються у генератор розширення простору розвитку особистості, стимулюють активність ї̈ самовизначення та самореалізації, сприяють більш успішному входженню в нові сфери творчої практики.

\section{Радєва М. М.}

доктор економічних наук, професор 


\section{РАЗДЕЛ 1}

\section{ИНСТИТУЦИОНАЛЬНАЯ ОСНОВА РАЗВИТИЯ ЭКОНОМИКИ}

Эфрфективное развитие экономики тесно связано с институциональными трансформациями, направленными на создание эфффективного собственника, макроэкономическую стабилизацию, результативное функционирование предприятий, повышение конкурентоспособности производства, создание условий для инноваций и социального развития страны. Процесс трансформации экономики при отсутствии необходимых институциональных предпосылок и организационного обеспечения приносит кроме положительных нежелательные последствия. Трудности трансформационных процессов стимулируют разработку более эффрективных методологических инструментов экономического реформирования.

\section{1. Методология институционального анализа развития} экономики

С 70-х гг. XX в. наблюдается всплеск интереса к институциональному анализу экономических процессов, связанный с попытками преодолеть ограниченность положений классической экономической теории - полной рациональности, абсолютной информированности, совершенной конкуренции, равновесного действия ценового механизма - путем использования методов права, социологии, политологии.

Каждая экономическая теория разрабатывает основные принципы функционирования экономики. Классическая политэкономия и неоклассика используют функциональный подход, объектом которого становятся гипотетические наборы альтернатив производства, а единицей анализа является индивид как упорядоченный набор преимуществ. Единица анализа институциональной парадигмы - институт. Эволюционная экономическая теория исследует экономическое поведение в процессе 
производства, а теория трансакционных издержек - экономическое поведение в процессе обмена. Новая институциональная экономическая теория (далее - НИЭТ) использует метод сравнительного анализа эффрективности различных фрорм собственности, выбор возможных вариантов интернационализации внешних эффректов и структур.

Институциональная экономика возникла как ответ на недостатки рынка, снижающие его эффрективность. Рынок представляет собой лишь относительную форму организации экономических отношений, которая была эффрективна в XIX - начале XX в. Институты заполняют рыночные провалы и повышают совершенство рынка, а современная экономика должна использовать эффективные механизмы и рыночной, и институциональной экономик. Корпоративная экономика вытесняет остатки рыночной конкуренции в классическом понимании и требует замены методологической основы управления корпорациями. Ограниченность неоклассической теории в объяснении взаимодействия экономических агентов, рост неудовлетворенности результатами неоклассического синтеза, неспособность прогнозировать социально-экономические явления и объяснять их последствия способствовали повышению интереса к институциональным методам анализа.

Можно выделить два концептуальных подхода современных институционалистов к определению термина «институт».

В соответствие с первым подходом, институт - это фрормальные и неформальные нормы и правила, ограничения и указания. Родоначальником американского классического институционализма Т. Вебленом впервые введено понятие институтов «как устойчивых привычек мышления, присущих большому сообществу людей» [31].

Термин «институционализм» ввел в научный оборот В. Гамильтон, который определял институт как пучок социальных обычаев. Толкование Т. Вебленом, Д. Нортом, Е. Фуруботном, Р. Рихтером института как «правил игры» предусматривает установление формальных норм (конституции, законов, правового поля, административной регламентации) и неформальных ограничений взаимодействия людей (привычки, традиции, 
условности, этические правила, табу). Институт является обычным способом реагирования на стимулы, господствующей духовной позицией или распространенным представлением об образе жизни в обществе [4, с. 201-202]. Институты - это созданные человеком, прописанные формальные ограничительные рамки, правила, дополнительные неписаные кодексы поведения, регламентирующие взаимоотношения между людьми, определяющие структуру побудительных мотивов человеческого взаимодействия в политике, социальной сфере и экономике [39, с. 17]. Институты представляют собой правила и механизмы, обеспечивающие выполнение правил, нормы поведения, структурирующие повторяющиеся взаимодействия между людьми [40, с. 73]. Институт рассматривается как механизм управления контрактными отношениями, вследствие чего центр институционального анализа перемещается на уровень косвенных или отдельных трансакций [5].

Институты определяют нормы, правила, стандарты и побудительные мотивы человеческого поведения, они связаны с экономическими интересами и отражают результат системы ценностей, сложившейся в обществе. Институты соединяют непосредственно правила и внешний механизм принуждения индивидов к выполнению устоявшихся правил [64, с. 7, 26]. Институт как совокупность формальных и неформальных правил упорядочивают взаимодействие между людьми и решают распределительные конфликты в условиях ограниченности ресурсов. Институты нуждаются в механизмах обеспечения их соблюдения и санкционирования и выполняют ограничительную функцию [74, с. 15, 90].

Общепринято в экономической науке распределение институтов на формальные и неформальные. Формальными являются политические, юридические, экономические правила и контракты, иерархически делятся по объему ограничений на общие (например, конституции, законы) и конкретные (индивидуальные контракты). Политические правила в форме ограничения или расширения свободы определяют иерархическую структуру общества, обеспечивает процедуру принятия политических решений и контроля за ней. Экономические правила в денежной форме 
выгод и затрат регулируют права собственности, а контракты - конкретные соглашения по обмену. Развитие общества «от простого к сложному», возрастание сложности общества, способствуют созданию фрормальных юридических систем, обеспечивающих решение более сложных конфрликтов и споров [39, с. 67-68].

Формальные правила - это правовые нормы. Они создаются централизованно, вербально / письменно фриксируются и обеспечиваются легальной и специализированой защитой со стороны государства. Однако формальные нормы не всегда согласованные, логически последовательные, защищённые, широко известные и комплексные. Сегментарность правил, то есть ограниченность сферы действия и возможности обеспечить их выполнение, позволяет манипулировать ими, примером чего является нелегальная экономика $[40$, с. $73 ; 74$, с. $107,115-$ 116]. Именно поэтому формальные правила не становятся единственным и основным источником выбора модели взаимодействия агента с окружающими. Обязательным компонентом упорядочения сотрудничества между людьми является неформальные правила, не зафиксированные вербально и не защищённые легальными механизмами [39, с. 56-59].

Неформальные правила - обычаи, традиции, привычки, наборы стандартов человеческого поведения - возникают на основе информации, передаваемой через социальные механизмы, и становится частью культурного наследия. Система социального контроля предполагает разработку правил, которые содержат стандарты для оценки действий и сопоставления, и дополняется способами наказания. Неформальные ограничения возникают для координации устойчивых повторяющихся форм человеческого взаимодействия и становятся: 1) продолжением развития и модификацией формальных правил; 2) социально санкционированными нормами поведения; внутренне обязательными стандартами поведения [39, с. 61]; 3) канвой общественной жизни, определяющей набор доступных альтернатив; 4) источником формирования и изменения формальных правил; 5) заменителем формальных правил; 6) источником их противоречия [74, с. 117-120]. 
Существует и другой подход, согласно которому институт рассматривается как учреждение и организация. В соответствие с этой позицией, организация - обособленный институт [2, с. 12]; социальный институт, выполняющий определенные функции [50]; единица координации с формальной структурой властных отношений [33]; самостоятельный институт, имеющий внутреннюю организацию и состоящий из совокупности отдельных микроинститутов [31, с. 22-23; 71, с. 52]. А. Шаститко указывает на тождество понятий «институт» и «организация». Организацию он определяет как целостное множество экономических агентов, обеспечивающих трансформацию ресурсов в продукт; как сеть контрактов между собственниками ресурсов для обеспечения обмена между ними; как пучок контрактов между участниками процесса воспроизводства ценностей $[74$, c. 91].

Чаще всего понятие института соотносится с правилами и механизмами санкционирования. Правила, общепризнанные и защищенные нормы, ограничивают набор доступных стратегий, запрещая или разрешая определенные виды действий при взаимодействии. Обеспечение действенности правила нуждается в поддержке соответствующими механизмами санкционирования (поощрения или наказания), влияющими на выбор экономических агентов. Санкции можно классифицировать по критериям мотивации (стимулирующие и дестимулирующие), субъектности (субъекты-гаранты, объекты-гаранты) и формы (экономические, политические, нравственные - по Дж. Коммонсу) [19;70; 74, с. $106-107$, с. $114-116]$.

Институты с помощью формальных и неформальных «правил игры» устанавливают равновесие между отдельными элементами институциональной среды, а институциональное развитие каждого элемента направлено на самосохранение структуры среды. Институты имеют повторяющийся характер и обеспечивают оформление стабильных образцов и методов воздействия экономических агентов, облегчают взаимодействие и обмен между элементами институциональной среды. Структура и характеристика каждого из элементов институциональной 
среды обусловливают выбор и использование специфических организационно-экономических механизмов функционирования и развития каждой отдельной корпораций. Действие системных законов самоорганизации, обеспечивает взаимодействие институтов и институциональных форм, позволяет прогнозировать способность приживания трансформированных элементов.

Появление институционализма обусловила необходимость объяснения особенностей функционирования экономических институтов и институций, которые не полностью вписывались в модель совершенной конкуренции.

Отказ от использования формализованных методов исследования, логических процедур и абстракции способствовала максимальному приближению выдвинутых гипотез и теорем к реалиям исследуемой проблемы. Из-за отсутствия универсальных методов институционального анализа произошло разветвление институциональных течений, выделились классический институционализм, новый институционализм, неоинституционализм, институционализм-регуляционизм (фрранцузский институционализм), эволюционизм, НИЭТ.

Ранний институционализм (20-е гг. XXв.) отверг основной постулат неоклассики об индивидуалистической конкуренции. Институционалистыклассики считали, что анализ поведения организации (фирмы) должен включать как экономические, так и неэкономические фракторы, отрицая идею гедонизма (человека экономического, которая стремится только максимизации выгоды). Развитие предприятий классический институционализм объясняет эволюционным принципом естественного отбора как результата эволюционных трансформаций экономических институтов.

Послевоенный институционализм 50-х гг. XX В. использовал концепцию «независимого индивида» для исследования влияния крупной организации на научно-технический прогресс и политические процессы.

Послевоенные институциональные концепции середины прошлого столетия признали крупное предприятие основной движущей силой 
экономического прогресса. Ведущие подходы к развитию крупного предприятия определили разновидности теории индустриального общества. Это индустриально-технократический подход Дж. Гилберта (1967 г., 1973 г.); теория стадий общественного развития У. Ростоу (1960) институционально-социальное направление А. Берли (1955), Г. Минса (1962) и Ф. Перри (1961) теория «государства всеобщего благоденствия» П. Самуэльсона. Дальнейшее теоретическое обоснование развития предприятий нашло отражение в концепции постиндустриального (информационного) общества Д. Белла (1973) и Ж. Фурастье (1957 - 1961).

Дальнейшие исследования современных институционалистов, в том числе теория фрирмы, развивались по двум направлениям: новая институциональная экономическая теория и неоинституционализм. Несмотря на сходство названий, основу этих подходов составляют различные научные парадигмы. Отличие между ними заключается в глубине модификации неоклассического подхода в соответствии с концепцией Т. Еггертсона, предложенной в 1990 г. [27].

Устранить разногласия между прорыночной предвзятостью неоклассики и пренебрежением экономическими факторами в новом институционализме пытается неоинституционализм путем синтеза этих двух парадигм. Методологию исследования предприятий эта теория дополняет методами анализа институциональных факторов, таких как право собственности, политическая власть, трансакционные издержки, риски, возможности оппортунизма контрагентов, влияние социальных, моральных и политических факторов и тому подобное. Неоинституционализм сочетает неоклассическую концепцию выбора стимулов с институциональной концепцией развития институтов как важнейшего условия эффрективного функционирования экономической системы. Неоинституциональный подход считает необходимым согласовывать использование неоклассических методологических принципов индивидуализма, максимизации полезности, ограниченной рациональности экономических объектов, оппортунистического поведения с социально приемлемыми инструментами и методами развития 
институтов.

Новая институциональная экономическая теория разрабатывает концепции постиндустриального и постэкономического общества, концепции конвергенции, глобальной экономики, отвергая неоклассические принципы рационального выбора, методы маржинального и равновесного анализа. Важнейшим инструментом нового институционализма становится сравнительный анализ дискретных институциональных альтернатив. Основу ново-институциональных концепций составляют знания и человеческий капитал как приоритетный объект инвестирования, а сферы анализа выходят за пределы рыночного хозяйства. Адаптивная индустриальная фрирма (корпорация) Э. Тоффрлера трансформируется в креативную, которая, приспосабливаясь к творческому потенциалу работников, формирует новые ценностные ориентиры (саморазвитие, доверие и сотрудничество).

Процессы возникновения и развития организаций, по мнению ученых-институционалистов, обусловлены эволюционным принципом естественного отбора вследствие изменения экономических институтов и разнообразия их форм. При этом экономическая система рассматривается учеными как «кумулятивный процесс» с причинами и последствиями, а не «самоуравновешивающийся механизм».

Основные теоретические направления институционального анализа внутренних и внешних механизмов функционирования экономических отношений определены в трудах зарубежных ученых:

- эволюционной теории Д. Норта;

- новой теории прав собственности Л. Аллеса, Д. Бромли, Г. Демсеца, С. Пейовича, Е. Фуруботна;

- новой теории принятия решений Г. Саймона;

- теории трансакций Д. Бромли, Дж. Коммонса, А. Уильямсона;

- теории трансакционных издержек А. Алчияна, И. Барцеля, Р. Коуза, С. Мастена, Д. Норта, О. Уильямсона;

- теории контрактов, агентских отношений М. Аюки, Б. Клейна, Я. Макнейла, В. Меклинга, А. Уильямсона, Е. Фамы; 
- новой теории фрирмы А. Алчияна, М. Аюки, Х. Демсетц, Г. Миллера;

- теории экономической истории Л. Дэвиса, Д. Ная, Д. Норта, Р. Познера, Д. Умбека;

- теории идеологии А. Денцау;

- концепции знаний Ф. Хайека.

Развитие фрирмы эти ученые рассматривают с позиций формирования структуры и поведения самой фрирм и родственных организаций вместо анализа норм концентрации, норм прибыли, измерения эфффекта от увеличения масштабов производства и межотраслевой регрессии.

Проблемы институциональных изменений, сопровождающих трансформационные процессы, занимают ведущее место в современной теории институционализма. Новые ограничения и новые возможности становятся причиной несоответствия институциональной оболочки запросам экономики и одновременно позволяют системе отобрать элементы, пригодные для строительства новой институциональной системы.

Создание мощного корпоративного сектора экономики путем слияния и поглощения в течение 1930-1980-х годов объясняется институциональным сдвигом. Решение проблем вертикальной интеграции осуществляется с использованием теории трансакционных издержек и теории неполных контрактов в условиях ограниченной рациональности, соглашательства, специализации активов в работах Р. Коуза, Дж. Гэлбрейта, А. Алчияна, Б. Кляйна, А. Уильямсона, Г. Гроссмана, В . Харта. Ученые исследуют границы между фрирмами и рынками, структуру фрирмы, природу контрактных взаимоотношений между экономическими агентами на разных уровнях производственной цепочки. Разработку теории, в первую очередь, связывают с именами двух экономистов - Р. Коуза и О. Уильямсона [53, с. 22-26].

Исследование Р. Коуза, опубликованное еще в 1937 г., дало теоретического обоснования процессам вертикальной интеграции, пик 
которых пришелся на последнюю четверть XXв. Первоначальные взгляды ученого, связывали процессы интеграции с попыткой мелких предприятий получить преимущества крупномасштабного производства [25, с. 57], постепенно трансформировались в теорию трансакционных издержек. Термин «транзакция», под которым понимают акт экономического взаимодействия и операцию, широко используется для определения обмена товарами, юридическими обязанностями, краткосрочными и долгосрочными действиями. Первоначальное толкование Р. Коуза трансакционных издержек как «расходов на пользование рыночным механизмом» был расширен до признания трансакционными любых видов расходов, сопровождающих взаимодействие экономических агентов на рынке или внутри иерархии [21, с. 1].

Теория трансакционных издержек, впервые изложенная в работе P. Коуза «Природа фрирмы» (1937 г.) отрицает неоклассическую рациональность выбора рыночными субъектами на основе полной информации. Ученый указывает на наличие, по крайней мере, двух координационных механизмов распределения ресурсов предприятия: ценового и иерархического. Автор «теории трансакционных издержек» доказывал, что рынок, как сфера обмена правами собственности, требует производственных и трансакционных издержек, связанных с координацией, взаимодействием, обменом и защитой прав собственности. К трансакционным относятся расходы на сбор и обработку информации, проведение переговоров, принятия решений, контроль и юридическую защиту выполнения контрактов [24, с. 30-45].

Работы по проблемам трансакционных издержек и прав собственности $[24 ; 25 ; 77 ; 78 ; 85 ; 86]$ стали источником новой теории интеграции, согласно которой увеличение размеров корпорации происходит на основе анализа экономической целесообразности замещения рыночных трансакций корпоративными при предельно возможной прибыли. Р. Коуз очертил научный подход к изменению размеров фрирмы: фирма увеличивается, если предприниматель организует дополнительные трансакции, а уменьшается, когда он 
прекращает такую организацию.

Стратегические решения в области кооперации составляют основу трансформации предприятия, а механизмом установления оптимальных размеров корпорации становятся трансакционные издержки. Мотивом создания и развития корпораций является экономия трансакционных издержек за счет интеграции в рамках одной корпоративной структуры. Одновременно осложнения организационных структур затрудняет координацию и стремительно повышает трансакционные издержки. Увеличение корпорации происходит до черты, за которой трансакционные издержки корпорации начинают превышать трансакционные издержки свободного рынка. Фирма расширяется до тех пор, пока расходы на организацию дополнительной трансакции в корпорации ниже затрат на проведение такой же сделки на рынке. «Результат всего этого институциональная структура производства, которая минимизирует общие затраты на производство продукции» [25, с. 91].

Р. Коуз считал, что «... работа рынка чего-то стоит и определенные рыночные затраты можно сократить, создав организацию ... с меньшими затратами, которая может получать факторы производства по меньшей цене, чем при рыночных трансакций, которые она замещает» [24, с. 35]. Ученый доказывал, что фрирма и рынок - альтернативные способы организации одинаковых сделок, а корпорация решает дилемму: сделать самой или купить на рынке. Рыночные трансакции обмена заменяются трансакциями координации на предприятии. Именно трансакционные издержки обусловливают существование определенных организационных структур вообще, но все производство не осуществляет одна крупная фрирма $[24$, с. 32 , с. $36 ; 51$, с. 12]. Минимизация трансакционных издержек в пределах институционального образования как решающий критерий становятся основой для выбора организационной формы и оптимального размера фрирмы, принятия решения о создании новых структур для изготовления ресурсов. Решения принимаются на основе предельных издержек, связанных с созданием корпоративных структур и рыночными сделками. Теория обеспечивает методологическую базу для изучения 
организационной динамики в корпоративных структурах как отражение реализованных контрактов и позволяет выявить критерии и механизмы создания корпоративных структур.

Таким образом, фрирмы возникают как результат дороговизны рыночной координации вследствие рыночных трансакционных издержек, однако трансакционные издержки административного механизма также растут с увеличением размеров фрирмы, из-за чего фрирмам не выгодно увеличивать свои размеры.

Классический пример значительных трансакционных издержек демонстрирует переходная экономика, в которой отсутствует и / или недоступна асимметрично распределенная информации, что провоцирует оппортунистическое поведение. Невозможность обеспечения исполнения контрактов легальными способами и потребность использования нелегальных средств связана с огромными затратами - денежными и не только. Желание уменьшить трансакционные издержки за счет корпоративной интеграции предопределяет создание относительно замкнутых промышленно-фринансовых империй, которые объединяют промышленные предприятия, банки, страховые компании, предприятия добывающей отрасли, телеканалы, газеты и т.д. [26, с. 22].

Сравнительно-институциональный подход А. Уильямсона [84; 374] признал наличие широкого диапазона институциональных структур, используемых для минимизации общей стоимости осуществления трансакций между экономическими агентами. Фирмы могут выбирать множество различных управленческих структур, которые представляют собой специфический набор избранных институциональных структур для управления трансакциями.

А. Уильямсон к оценке корпоративных процессов (интеграция, приобретение / поглощение, олигархия, ффинансиализации) с институциональной точки зрения использует два подхода: стимулирующая оценка и процессуальный анализ. Ученый считает, что интеграция передает тому, кто приобрел активы, фактические права решения о вмешательстве, что приводит к различным искажениям. Достижения 
интеграции (прежде всего, большая приспосабливаемость) вызывают расходы, в частности, искажение операционных решений при переносе к фирме мощных стимулов рынка. В то же время корпорация способна эффрективнее использовать инструменты контроля, чем рынки, в результате чего привлекательным становится использование организационных стимулов вместе с инструментами контроля. Институциональный выбор (принятие решения об интеграции) может варьироваться в диапазоне от вполне отрицательного (рынок) до вполне положительного (иерархия) и отличается степенью углубления специализации активов. Распространение процессов приобретения / поглощения связано с необходимостью внедрения организационной инновации. Появление многопрофильного предприятия становится ответом на необходимость устранения недостатков унитарного предприятия. Такая организационная форма способна обеспечивать экономию за счет ограниченной рациональности и обезопасить сделки от угроз, создаваемых соглашательством [5, с. 113-145].

Работа А. Уильямсона [84] изменила взгляд, традиционно подозрительный, на антитрестовского политику, вокруг которой развивалась современная промышленная организация. Ученым было обосновано институциональные предпосылки создания таких корпоративных структур, как вертикальная организация, контрактные вертикальные ограничения, совместные предприятия, горизонтальные соглашения, которые не попадали под категорию «естественные последствия действия совершенной конкуренции», независимо от положений классической экономической теории [15, с. 163].

Дж. Гилберт развитие фирм и увеличение их размеров связывал с необходимостью получения бюрократических преимуществ за счет эффрективных размеров предприятия, что позволяет использовать преимущества монопольного положения компании. Гигантские размеры корпорации обеспечивают достижение целей техноструктуры: защита, рост, престиж, доход и другие блага. Преимущества монополии (или олигополии, действующей как монополия) при установлении цены, 
увеличении объемов капиталовложений, специализации, управлении затратами, внедрении новых технологий направлено увеличение объемов продаж и рост корпорации [12, с. 43, 51].

Между трансакционными характеристиками и институциональными структурами существуют причинные связи. Задача фрирмы найти способы измерения вариаций в выборе управленческой структуры и согласовании этих выборов с мерами ассоциированного уровня специфичности активов. Какой способ организации сделки выберут ее участники - вертикальную интеграцию, долгосрочный контракт или наличную рыночную торговлю определяет каркасная теория [12, с. 163-171].

Фундаментальная дилемма институционального развития заключается в поисках компромисса между трансакционными и трансформационными издержками с целью обеспечения минимизации издержек производства. Институциональные соглашения, которые определяют способы кооперации и конкуренции, ограничивают набор возможностей для экономического агента, изменяя преимущества. Корпоративный разделение труда увеличивает риск оппортунизма, что приводит к повышению неявных трансакционных издержек. Ограничение разделения труда при низких явных трансакционных издержках увеличивает трансформационные затраты и, соответственно, неявные трансакционные издержки. Распределение трансакционных издержек определяет направления институциональных сдвигов в структуре экономики, стимулируя или препятствуя развитию отдельных видов деятельности и сорер.

Специфичность активов в зависимости от количества заинтересованных пользователей влияет на отказ от управления средствами простых наличных рыночных трансакций в пользу вертикальной интеграции.

Выбор между долгосрочными контрактами и средствами вертикальной интеграции исследуют А. Алчиян, Б. Кляйн, Р. Кроуфорд [82], опираясь на положения о специализации активов и, как следствие, фундаментальную трансформацию. Инвестиции в специфические активы 
«замыкают» количество равноценных контрагентов на одном и превращают начальную конкурентную ситуацию в конечную монопольную, которую А. Уильямсон назвал фундаментальной трансформацией главным препятствием на пути рыночного обмена. Ученые доказывают, что привлекательной альтернативой наличным рынкам могут стать долгосрочные контракты, однако их выполнение может быть связано с координационными проблемами, вызванных спецификой инвестиций (активов).

Специализированность активов характеризуется степенью переназначения конкретного актива другому пользователю или альтернативного использования без потери продуктивной ценности актива. Интернационализация трансакций облегчает решение этих проблем, увеличивает вероятность вертикальной интеграции. Вероятность вертикальной интеграции увеличивается с ростом специализации активов и образованием большей суммы присвоенных квазирента. Рост квазиренты и специализации активов провоцирует соглашательское поведение, в результате чего расходы на контракты целом будут расти быстрее, чем затраты на вертикальную интеграцию. Преимущества интеграции связаны с усилением контроля над активами, способностью решать спорные вопросы средствами принуждения со стороны собственника, уменьшением уровня асимметрии информации.

$$
\text { Характерный для теории эволюции Й. Шумпетера }
$$
эволюционирующий микроподход признает правила и способы поведения как специфические активы предприятия. Отказ от старых правил (за Нельсоном и Уинтером - «рутин») целесообразен только при условии возмещения потерь на замену старых правил и получения выгод от введения новых. Эволюционисты достаточно скептически оценивают перспективы приватизации, считают невозможной эффективную замену старых рутин на предприятиях, обосновывают целесообразность вложения государственных средств в поддержку развития новых предприятий, не обремененных старыми рутины [26, с. 21].

В работе Г. Гроссмана и А. Харта [81] исследуется влияние 
остаточных прав контроля над фризическими активами на предыдущие решения о специфических инвестиции. Теория основывается на специфичности активов, квазиренте и проблемах неполных контрактов, однако сосредотачивается исключительно на физических активах [69, с. 195]. Адаптивные выгоды вертикальной интеграции иногда больше чем компенсируются инвестиционными искажениями, возникающими вследствие этого. Ученые определяют три альтернативные виды собственности по признаку интеграции: 1) первая стадия приобретет вторую, 2) вторая стадия приобретет первую, 3) отсутствие интеграции (стадии независимые. Выбор между интеграцией и независимостью связан С проблемой уменьшения стимулов при распределении прав собственности. Решение стимулирующих проблем требует не только эфффективной передачи контроля над различными частями денежного обращения различным управленцам, но и деления права собственности и контроля для обеспечения этой передачи, которую эффективно организует корпорация. Общий вывод ученых: вертикальная интеграция более вероятна, когда активы специфические $[14$, с. 230]. Процесс замещения одной альтернативной формы институциональной сделки другой (рынок, гибрид, иерархия) определяется параметрическими сдвигами институциональной среды [74, с. 50; 83, с. 543].

Вертикальная интеграция является не просто вопросом трансакционных издержек, а, следовательно, сказать: «фирмы производят собственные ресурсы, когда это дешевле» - не то же самое, что сказать: «фирмы покупают у других, если трансакционные издержки меньше управленческих» [79]. Процессы увеличения размеров фирмы обосновываются увеличением трансакционных издержек, что приводит к замещению организационной координации.

Организационная координация связана с тремя фракторами: специализацией, продолжительностью (сроком) связи, зависимости от управления. Из теории трансакционных издержек следует, что фрирмы способны производить товары / услуги одинаково хорошо, независимо от различий между фрирмами [14, с. 223-225]. 
Теории трансакционных издержек используется для выбора инструментов фринансирования корпоративных инвестиционных проектов. Финансовые инструменты (собственный капитал, заемный капитал, другие источники фондов) становятся альтернативными структурами управления и получают контроль над корпорацией. Такой подход к формированию корпоративных фринансов предопределяет дифференцированное использование заемного и собственного капитала как функции свойств инвестиционных проектов. Акционерный капитал - громоздкая фрорма управления, последний фринансовый инструмент, который задействуют на поздней стадии. Диффреренцированное использование финансовых инструментов становится еще одной разновидностью минимизации трансакционных издержек, преимуществом интеграции является способность контролировать учетные процедуры [5, с. 133; 69, с. 208].

Теория трансакционных издержек обмена представляет собой симбиоз теории человеческого поведения и теории издержек трансакций. Расходы на информацию, одна часть которых расходуется на оценку нужных свойств объекта обмена, а другая - на обеспечение прав, становятся источником социальных, политических и экономических институтов. Трансакции потребляют значительную часть издержек производства (45\% национального дохода США) и имеют тенденцию к увеличению (на 25\% за последнее столетие). Попытки каждой стороны, участвующей в обмене, установить в объекте ценные для нее свойства, вызывают трансакционные издержки [39, с. 45-48]. Теория трансакционных издержек обмена противостоит стандартной неоклассической модели Вальраса, описывающей мгновенный процесс обмена идентичными товарами, каждый из участников которого располагает полной информацией о товаре и условия сделки [80].

Соответствие уровня развития производственных отношений (отношений собственности) уровню развития производительных сил (закон единства производительных сил и производственных отношений) интенсивно проявляется в пределах интеграционных образований, порождая потребность в постоянном расширении таких группировок и 
присоединении новых членов [35, с. 10].

Дальнейшее методологическое обоснование процессы развития экономики нашли в институциональной теории прав собственности, которая выработала основу для анализа структуры отношений собственности.

Р. Коуз, А. Алчиян, Г. Демзетц, А. Харт, Г. Гроссман, Дж. Мур исследователи экономической теории прав собственности - трактуют права собственности как совокупность формальных и неформальных норм, упорядочивающих отношения между участниками экономического процесса и влияющих на принятия ими экономических решений. Институциональная теория, не признавая абсолютности права собственности, внедряет понятие «остаточные права контроля». В условиях неполного контракта остаточные права контроля порождают определенный механизм со средствами восполнение недостатков контракта [69, с. 194]. Взаимосвязь права собственности с остаточными правами контроля составляет основу теории интеграции Г. Гроссмана и А. Харта [81], которая связывает права собственности на активы с владением остаточными правами контроля над этими активами. Процессы корпоратизации превращают обычные контрактные отношения на такие, в которых наемный работник признает в определенных пределах власть работодателя. Создание корпоративных структур за счет интеграции меняет контроль над фризическими активами. Остаточные права контроля над человеческим капиталом возникают вследствие трудовых отношений между фирмой и наемным работником [69, с. 195, 207].

Развитие фрирмы является результатом специализации в использовании набора прав, осуществляется на основе сравнительных преимуществ экономических агентов. Открытая корпорация демонстрирует классический пример распределения правомочий: право на получение дохода имеют акционеры вместе с готовностью нести риск и ответственность за действия наемных руководителей, а право на распределение ресурсов и координационные действия в форме управления - менеджмент. Конфликт интересов является результатом 
соблюдения собственных интересов индивидом в условиях ограниченности ресурсов и неопределенности [74, с. 110, 139]. Можно предположить, что процесс корпоративного распыление прав собственности снижает ценность объектов корпоративной собственности.

Под влиянием внешних эффректов конкуренции возникает конфлликт прав собственности. Расширение прав одного индивида (менеджмента) ограничивает права другого (владельца), в том числе на получение дохода. Угроза неудовлетворительных распределительных последствий обладания правами-правилами способствует возникновению координационных институтов как механизмов страхования институциональных новаторов в условиях рациональной неосведомленности [22; 74, с. 113-114].

Теория агентских отношений «принципал - агент» М. Дженсена и В. Меклинга, расширенная в трудах Дж. Стиглица, А. Уильямсона, Т. Еггертсона, Ф. Фама, А. Харта, является научным основанием экономического анализа для нахождения механизмов эффрективного контроля поведения наемных менеджеров владельцами компании.

Исследование проблемы «принципал-агент» основывается на предположении, что принципал имеет достаточную власть для подчинения себе агента, который, в свою очередь, имеет возможность наблюдать за соблюдением принципалом своих обязательств. Эти два фрактора становятся основой для выполнения соглашения. Определение прав собственности и контроль за их соблюдением связаны с трансакционными издержками. Создание формальных юридических систем и развитие отношений иерархии в сложных организациях вызывает появление формальных структур, призванных регулировать отношения «принципал агент» [39, с. 52, 67-68].

Различия в построении институциональной структуры определяют пропорции между формальными и неформальными средствами защиты прав собственности. В корпоративных отношениях в условиях асимметрии информации дилемма принципала (владельца компании) заключается в выборе между необходимостью контролировать агента (менеджера), 
который может демонстрировать оппортунизм, и нежеланием принципала осуществлять этот контроль, сопровождаемый значительными затратами. Отношения «принципал - агент» сосредоточены на мотивах и условиях обеспечения исполнения контрактов. Такими мотивами могут стать убеждения и кодексы поведения, опасения последствий действий другой стороны в ответ, угроза привлечения экономических и социальных санкций и принуждения со стороны третьих лиц (например, государства и общественных организаций). Отсутствие институциональных ограничений и асимметрия информации, помноженные на заинтересованность в обеспечении только собственных интересов, мешают развитию контрактных отношений и повышают трансакционные издержки, в том числе и премии за риск.

В теории трансакционных издержек значительное внимание уделяется проблеме оппортунистического поведения менеджмента, выраженом во лжи, обмане, пренебрежении обязанностями, бездействии менеджеров. Отсутствие эффрективного контроля дает возможность агенту действовать в соответствии с собственными интересами, не совпадающие с интересами фрирмы [21, с. 1-2]. Н. Калдор и Е. Робинсон считали уменьшение отдачи управленческого ресурса при увеличении корпорации основным ограничивающим фактором размера последней [25, с. 12].

В 70-е гг. XX в. проблема отделения собственности от управления, которую рассматривали А. Берли и Г. Минз, трансформировалась в задачу достижения стимулирующего выравнивания несовместимости в корпорации [14, с. 227]. А. Алчиян и Г. Демзетц [75] развитие вертикальных корпоративных структур объясняют с помощью различий в потребностях контроля. Обосновывая преимущества кооперации и командного взаимодействия, ученые обращают внимание на трудности оценки вклада каждого участника, порождающие стимулы к «уклонение». Ограничивающим фактором дальнейшего роста корпорации становится увеличение расходов на надзор для предотвращения уклонения, при котором издержки начинают преобладать над выгодами от увеличения размеров фрирмы. 
К. Лен и Г. Демзетц [80] поднимают проблему стимулирующей несовместимости вследствие морального риска, халатности и соглашательства, решение которой должно сочетать задачи эффективной внутренней организации фрирмы и учета трансакционных издержек путем достижения оптимальной структуры собственности. Учеными предложено альтернативу анализа трансакционных издержек в виде подхода «стимулирующего выравнивания», который объясняет организацию фрирмы вариациями в системах контроля, направленных на разработку и функционирование стимулов для смягчения несовместимости [14, с. 228].

Наличие проблемы несовместимости стимулов вызвано разногласиями интересов экономических агентов из-за разницы их положения в системе экономических отношений, которую порождает специализация. Решение проблемы заключается в разработке стимулирующих контрактов, призванных обеспечить приемлемый уровень соответствия интересов управленцев и собственников. В основном невозможно приблизиться к «идеальному», полному, всеобъемлющему стимулирующему контракту, а соответственно, и решить эту проблему [74, c. $139,45,46]$.

Институционалисты - эволюционисты Д. Крепс и А. Чандлер исследуют внутрифирменные отношения с эволюционной точки зрения как производную от предшествующего развития предприятия в направлении социализации. Повышение социальной роли корпорации, уподобление корпорации к обществу, естественная неполнота контрактов повышают значение корпоративной культуры как своеобразного компенсирующего средства - инструмента адаптации агентов к предполагаемым изменениям.

Корпоративная культура определяется как ресурс, который идентифицирует корпорацию и увеличивает ее рыночную ценность. Корпоративная культура, обеспечивая честную репутацию в течение длительного функционирования корпорации, заставляет работника соглашаться на властные полномочия фрирмы. Фирму можно считать депозитарием репутации в преодолении неожиданных, непредвиденных обстоятельств. Репутационные активы могут замещать фризические, и 
возможен вариант, когда фрирма состоит исключительно из репутационного капитала. Остаются непонятными средства получения фрирмой хорошей репутации даже при наличии приличной репутации отдельного руководителя [69, с. 209-210].

А. А. Ткач определяет ведущую роль корпораций и потребность в новой корпоративной модели экономики, подчеркивает необходимость предоставления приоритета в формировании инфраструктуры корпоративной экономики. Корпорация представлена ученым как совокупность базисных институтов: собственности, организации, управления, распределения дохода. Корпоратизация рыночной инфраструктуры происходит по двум направлениям: во-первых, развитие внешнего (рыночного) и внутреннего (иерархического) обеспечение деятельности корпораций; во-вторых, распространение корпоративных форм хозяйствования на всю систему экономической и социальной инфраструктуры [65, с. 266]. Классическая корпоративная иерархия трансформируется в рыночные отношения купли-продажи: с одной стороны, покупка акций, с другой - вознаграждение в виде дивидендов без попечения проблемами корпорации.

\section{2. Институциональная динамика базовых институтов} экономики

Процессы развития экономики с позиций институционализма объясняются эволюционным принципом естественного отбора за счет изменения экономических институтов и разнообразия их фоорм. Институциональная методология исследования развития экономики использует специфические инструменты институционализма: трансакционные издержки и специфичность активов как условия принятия интеграционных решений; координационные институты как средства преодоления неудовлетворительных распределительных последствий обладания правами-правилами; остаточные права контроля как инструмент управления человеческими активами; стимулирующие 
выравнивания как способ преодоления оппортунистического поведения; стимулирующие контракты, призванные обеспечить приемлемый уровень соответствия интересов управленцев и собственников; неформальные (кодексы поведения) и фрормальные (законодательные ограничения) институты как мотивы и условия обеспечения исполнения контрактов; корпоративная культура как инструмент адаптации агентов к предполагаемым изменениям. Институциональная основа трансформационной экономики переходного общества находится в стадии формирования. Дальнейшие исследования должны обосновать факторы и закономерности выработки механизмов реагирования в условиях институциональных структурных сдвигов экономики.

Основой экономического роста является эффрективная структура экономики, базовые институты которой сформировались в результате институциональных преобразований как результата исторических изменений индивидуального поведения на основе неформальных норм. Такие изменения происходят медленно, но создают легитимную основу для установления законов, роль которых заключается в снижении уровня неопределенности путем установления устойчивой структуры взаимодействия людей [39, с. 21]. Существует механизм отбора и сохранения таких норм, обеспечивающие большую адаптационную эфффективность систем взаимодействия между людьми. Неформальные правила становятся продолжением формальных, уменьшают потребности В функционировании специализированного механизма принуждения. Однако действие «Х-фракторов» может приводить к непредсказуемым последствиям, то есть норма создается для одной цели, а фрактически выполняет другие фрункции [74, с. 110, 120].

Общество упорно хранит старые составляющие институциональной системы даже тогда, когда дискретные (революционные) институциональные изменения порождают новые фрормальные элементы и вызывают полное изменение формальных правил. Быстрые революционные преобразования часто приводят к результатам, противоположным ожидаемым. Противоречия мгновенной трансформации 
неформальных институтов как реакции на изменение формальных правил вызывает напряженность между ними, что значительно влияет на процесс экономических изменений [39 с. 21-66]. Быстрые революционные преобразования часто приводят к результатам, противоположным ожидаемым.

Неодинаковые темпы развития формальных и неформальных институтов порождают различные трансформации экономики. Прогрессивность эффрективных нефрормальных институтов на фоне консерватизма фрормальных отражает эволюционный характер изменений и обеспечивает сбалансированное развитие системы. Революционное изменение формальных институтов при неизменных нефрормальных приводит к нормативному разрыву и несбалансированному развитию экономики. Формальные и неформальные институты, которые остаются неизменными при изменении фракторов макросреды, вызывают экономическую отсталость и отсутствие динамики развития институциональной среды [47, с. 32-34; 71, с. 78].

Д. Норт выделил два уровня динамики экономики: уровень организационных структур и их отношений, на котором функционируют организации и рынки, и уровень институциональных правил, который обеспечивает действие институтов права, труда, управления, собственности. Различные уровни динамики вызывают два типа эволюции: эволюцию организационных структур и эволюцию институциональных правил. Организационные преобразования формируют новые хозяйственные отношения при неизменных «правилах игры». Институциональные преобразования изменяют эти правила, обеспечивая основу для организационных реформ. Направление институциональных изменений формируется на основе двух составляющих. Во-первых, зависимость организаций от институциональных рамок, в которых они возникли, порождает «эффрект блокировки», проявляющийся в дальнейшем создании конкретных организационных структур, отвечающих формальным и неформальным ограничениям. Во-вторых, может наблюдаться обратное влияние организации в результате изменения 
восприятия и реакции со стороны индивидов. Именно такая динамика вызывает глубокое различие в экономическом развитии систем и объясняет существование неэфрфективных институтов [39, с. 22-24].

Специфика структурных преобразований в условиях системной трансформации заключается в очевидной подчиненности организационных изменений институциональным преобразованиям, институциональной эволюции или институциональной революции.

Выделим подходы к типизации фракторов институциональных трансформаций:

1. В зависимости от уровня институциональной динамики: институциональные и институциональные.

2. В зависимости от типа воздействия: эволюционные (постепенные) и революционные (дискретные). Институциональные изменения воспринимаем как обязательный эволюционный элемент любой трансформации общества.

3. В зависимости от субъекта-инициатора: формальные, которые внедряются государством, и неформальные, складывающиеся под воздействием историко-национальных особенностей.

4. В зависимости от объекта применения: экономические и политические. Политические фракторы формируют правила экономические, определяющие права собственности и контракты, хотя наблюдается и обратное влияние структуры экономических интересов на политическую структуру.

Уточним фракторы институциональной динамики общества в направлении корпоратизации экономики:

- историко-национальные особенности;

- идея, трансформированная в приоритетные цели общества, проецируемого на установление общественно-этических норм и направленности общества, давление различных социально-экономических групп;

- культурные нормы, обеспечивающие приоритет индивидуального или коллективного, в том числе корпоративные; 
- нравственно-моральные принципы,

- силовое воздействие государства, реализованное путем политических и экономических реформ (разгосударствление, приватизация, корпоратизация)

- технологическое развитие, фрормирующее уровень развития производительных сил;

- законодательно-правовое поле.

Выделим фракторы институциональных изменений, результатом которых становится создание корпоративных структур:

- процессы слияния и поглощения;

- мировая конъюнктура;

- экономическая нестабильность;

- глобализация;

- интернационализация финансовых рынков;

- технологическое развитие и инновации;

- фринансовые ресурсы.

Специфика структурных преобразований в условиях системной трансформации заключается в очевидной подчиненности организационных изменений институциональным преобразованиям. Институциональная эволюционная теория выделяет два уровня динамики экономики - уровень институтов и уровень институций, определяющих два типа эволюции: эволюцию институциональных правил и эволюцию организационных (институционных) структур. Институциональную корпоративную динамику в развитых странах можно представить в виде последовательной смены неформальных правил, которая влечет за собой изменение фрормальных правил. Уникальность проблем трансформации украинской экономики связана с обратными процессами. Направление развития украинского общества определили институциональные изменения, реализуемые через принудительное реформирования отношений собственности путем приватизации и корпоратизации, ставших катализатором институциональных трансформаций.

Институциональные трансформации влияют на выбор структурно- 
институционной формы организации с учетом трансформационных и трансакционных издержек. Действие конкретных институциональных ограничений образует среду, закладывает рамки функционирования организации. Институциональные ограничения образуют структуру стимулов поощрения деятельности - плодотворной или неэффективной. Совокупное влияние институтов формирует институциональную среду.

Институциональная среда экономики - это совокупность социальноэкономических институтов различных уровней, соответствующих национальным особенностям и специфике практики хозяйствования и системы координации хозяйственной деятельности и образуют институциональные рамки взаимодействия через эволюцию фрормальных институтов (за счет развития законодательно-правовой базы ) и эволюцию неформальных институтов (за счет социального, экономического, культурного развития общества) и обеспечивают реализацию механизмов регулирования взаимоотношений в экономике, направленных на содействие достижению цели организации как институционального образования (функциональной единицы) и института (совокупности формальных и неформальных правил, связанных с реализацией права собственности).

Институциональная среда экономики представляет собой наложенную формальными и неформальными институтами совокупность ограничений и возможностей для развития предприятий данного сектора экономики, сознательно или спонтанно возникают в результате контрактных отношений и имеют динамический характер. Организация и / или государство осознанно устанавливает часть ограничений и возможностей для обеспечения индивидуальных, групповых и общественных интересов с минимальными трансформационными и трансакционными издержками. Вместе с тем динамичность институтов и их противоречивость оставляют в стороне непредсказуемую спонтанную составляющую функционирования институциональной среды.

Схематически институциональная среда экономики представляет собой совокупность взаимосвязанных элементов, каждый из которых 
образует поле своего влияния и испытывает на себе влияние других элементов. Институциональная среда экономики состоит из системных элементов-институтов, каждый из которых динамично развивается, имеет собственные цели, функции и внутреннюю структуру, активно взаимодействует с другими компонентами:

- институт менеджмента / труда, на который возложена ответственность за выживание и рост организации через механизмы координации и корпоративного контроля;

- институт владельцев компании через механизмы реализации корпоративных прав;

- нерыночные институты (социальные институты), в том числе институт государства как особый вид социального института;

- институт рынка, ответственный за конкурентное окружение корпорации;

- глобальные институты, включающие рыночные и нерыночные институты на глобальном уровне.

Элементы среды, которые могут иметь противоречивые цели, сосуществуют и взаимодействуют между собой как проблема.

Институт собственности фрормируют владельцы вместе с инвесторами. Он действует через внутренние механизмы корпоративного контроля за фрункционированием организации, к которым отнесем: наблюдательный совет, ревизионную комиссию, внутренние комитеты, общее собрание, корпоративную культуру и кодексы корпоративного управления. Институциональные смещение в экономике определяются изменениями в системе собственности. Институциональной основой создания и развития корпоративной экономики стала замена индивидуальной собственности на коллективную.

Трансформации частнособственнической экономической системы в корпоративную обусловленные потребностями инвестирования в развитие индустриального производства, необходимостью преодоления противоречий между ограниченностью индивидуальных средств отдельных предпринимателей и ростом стоимости индустриального 
производства (производственной инфраструктуры, технологий, техники, сырья, материалов). Именно акционерная форма обеспечила возможность наращивать капитал путем организационного объединения индивидуальных капиталов, удовлетворяя основной интерес владельца к возмещению и увеличения капитала [59, с. 33; 60].

Концентрация капитала способствовала быстрому развитию массового производства и объектов инфраструктуры. Одновременно акционерная форма капитала обеспечила возможность постоянного гибкого перераспределения финансовых средств между предприятиями, регионами, отраслями и странами в соответствии с изменениями эффрективности объектов [65, с. 195]. Капитал взял на себя системообразующие функции в обществе, стал важным институтом рыночного общества, одновременно избавляясь от институциональных ограничений собственного роста - неформальных (морально-этических) и даже формальных (законодательно-правовых). Постепенное накопление и концентрация капитала в качестве базисного, системообразующего элемента рыночной экономики повлекло трансформацию других основных элементов институциональной структуры общественной системы: собственности, власти, управления и труда [59, с. 37]. Происходит взаимодействие, взаимовлияние и постепенная эволюция стадий капитализма в соответствии с процессом концентрации капитала. Накопление капитала превращает рыночное хозяйство с персонифицированным капиталом и мелкотоварным производством в систему с высоким уровнем концентрации капитала и производства, изменяя организационно-правовую форму функционирования предприятия.

Институт менеджмента / труда образуют менеджмент, работники, органы управления и механизмы корпоративного управления, основанные на законодательстве и корпоративных кодексах отдельных организаций. Все множество нерыночных институтов, составляющих часть внешней среды компании, условно делится на политические (система государственного регулирования, государственные организации, 
налоговая, нормативно-правовая, судебная, исполнительная системы) и социальные институты (СМИ, институт общественного мнения, кодексы корпоративного управления, бизнес-культура). Нерыночные институты развиваются под влиянием идеологии и менталитета общества.

Рынок формируется как совокупность рыночных институтов макро- и микроуровня, в которых находится компания. На макроуровне на деятельность организации влияют инвестиционный климат, структура отношений собственности, наличие и значимость предпринимательских объединений; развитие рыночной инфраструктуры, развитость финансовой системы и ее важнейших составляющих - фондового рынка и банковской системы, действенность институтов санации и банкротства, активность процессов слияния и поглощения. Условия функционирования организации на микроуровне устанавливают конкуренты, поставщики, спрос, предложение, потребители, цена. Взаимное влияние рыночных институтов на организацию и ее обратное влияние на рынок обуславливают рыночную конкуренцию, определяющую специфику рыночной деятельности и особый способ функционирования организации на рынке.

Рынок представляет собой механизм спонтанной конкуренции. Рынок, как и централизованная структура, является информационным устройством, образующим инструменты выявления, передачи и взаимосвязи рассеянных в обществе знаний. Рынок способен эти знания эффрективно координировать и использовать. Фундаментом функционирования рынка как системы является конкурентоспособный субъект. Специфику рыночной деятельности и особый способ функционирования организации на рынке определяет, прежде всего, рыночная конкуренция. Но так называемые «провалы рынка» не всегда обеспечивают оптимальное развитие отдельной организации и экономики в целом. Эффрективность развития определяется совокупным влиянием двух координационных сил - инструментов саморегулирования рыночной экономики и механизмов государственного регулирования институциональной экономики. Задачей государства является 
формирование и развитие институтов и институций для компенсации регуляторных провалов рынка. Поэтому институциональная экономика обеспечивает поиск оптимального соотношения базисных институтов, за счет чего происходит отбор и развитие форм экономической интеграции.

Глобализационные процессы даже усиливают роль государства в экономической жизни, повышая необходимость создания новых государственных институтов [47, с. 263]. Институциональная структура корпоративной экономики является результатом действия метаконкуренции. Важным фрактором эффрективности функционирования организаций становятся контракты и средства обеспечения их выполнения. Контракты - механизмы стандартизации и декларирование действий по приобретению и распоряжения правами собственности. Контракты осуществляются, когда фрактор производства за определенное вознаграждение соглашается подчиняться указаниям корпорации в определенных пределах. Контракты обусловливают институциональные границы власти организации, в которых последняя может управлять факторами производства.

Глобальные институты, к которым отнесем глобальные корпорации, мировую финансовую систему, экономические интеграционные союзы, транснациональный капитал, глобальный спрос и предложение, глобальную конкуренцию, слияния и поглощения, корпоративные принципы, распространяют действие рыночных и нерыночных институтов в глобальную экономику. Глобальная экономика стала последовательным этапом развития мировой экономики. Глобализация, как важный элемент институциональной среды организации, выступает одним из источников новых возможностей и одновременно становится причиной многих конфрликтов и проблем на государственном и международном уровнях. Институты глобальной экономики развиваются согласно логике развертывания процессов глобализации [48, с. 37].

Традиционное утверждение, что в конкурентной экономике «внешние институты не попадают под влияние организации, меняется в глобальной экономике. Корпорация - глобальный институт, концентрирует ресурсы и 
обладает инструментами взаимодействия с национальными экономиками и правительствами - не только влияет на институциональные изменения, но и частично устанавливает векторы этих изменений. Зрелая корпорация самостоятельно продуцирует / модифицирует элементы внешней среды, которые становятся специфическим продолжением самой корпорации и инструментами приспособления корпорации к обществу. Корпорация производит средства адаптации для изменения рамок институциональных ограничений.

\section{3. Институционное обеспечение развития экономики}

Государство фрормирует внешний ограничительный институт, регулирующий деятельность организации и других общественных объединений данного общества. Государство обеспечивает создание и выполнение норм осуществления хозяйственной деятельности. Задача национальной политики связана с достижением высоких стандартов и безопасности жизни населения страны, созданием достойного уровня жизни и достойных условий для труда и отдыха, устранением и смягчением социальных противоречий, обеспечением личной безопасности. Реализация этих задач требует создания эффективных механизмов защиты национальной безопасности Украины и ее независимости; интегрирования украинской экономики в мировое хозяйство; обеспечение внутренних потребностей страны на основе развития корпоративного сектора экономики. Решение этих задач требует понимания механизма принятия правительственных решений.

Экономическая теория предлагает разнообразные и даже противоположные методологические подходы к формированию государством системы институтов регулирования. Кейнсианцы исповедуют принципы максимальной выгоды, в рамках государственного регулирования правительства принимают решения, исходя из прогнозных результатов влияния кредитно-денежных и финансовых мер на экономику.

Неоклассическая теория, представлявшей рынок через 
множественность мелких равносильных предприятий, не имеющих экономической и политической власти, отводит государству вспомогательную роль в сферах, в которых нельзя полностью полагаться на рынок: национальная оборона, образование, защита населения и собственности, экология. Используя модель общего равновесия, неоклассическая теория считает функцией государства снятие искусственных препятствий, сдерживающих экономическую свободу для обеспечения достаточной трансформационной динамики. По мнению неоклассиков, свободные цены ликвидируют денежный избыток, образованный диспропорциями цен и дефицитом, и устанавливают относительные цены, отражающие реальную меру редкости благ. Сопротивление трансформационным процессам и реструктуризации преодолевается силой государства и уменьшается при увеличении динамики трансформации [26, с. 19].

Либеральная теория предполагает

минимальное участие государства в рыночной экономике, для уравновешивания несогласованных спонтанных действий.

Сторонники классического институционализма, в соответствие с принципами индивидуализма и согласно теории общественного выбора, считают, что выбор правительственного решения основывается на оценке ожидаемого влияния последствий принятого решения на престиж чиновника.

Новый институционализм определяет механизмы государственного управления как рамки возможностей и ограничений выбора альтернатив человеческих отношений. Адекватность подхода нового институционализма в современных условиях можно объяснить действием правила «выборочной социальной справедливости», которая отличается для отдельных членов общества и социальных групп. Удовлетворение социальных потребностей требует вмешательства государства через создание соответствующих институтов. Согласно теории нового институционализма, выбор программ развития страны базируется на выполненные норм - обязательных правил поведения. Несправедливость 
требует применения государством норм, но удовлетворить всех без исключения невозможно. Правительственное решение основывается на определенных стандартных ограничениях и возможностях, с учетом приоритетной части населения, и может быть приемлемым только для части общества, большей или меньшей.

Ограничения, которые накладывает на себя экономический агент, помогают структурировать отношения с окружающими. Незначительная часть таких ограничений носит формальный характер. В идеале, основой создания формальных институтов становятся неформальные нормы, функционирующие в хозяйственной практике, которые постепенно распространяются и приобретают легитимность. Вместе с тем институты как результат прошлых процессов являются факторами социальной инерции, они не способны обеспечить дальнейшее развитие только через функционирование неформальных норм. Это требует легализации неформальных норм силой закона и превращения их в фрормальные. Особенно этот процесс касается государственной власти и создания политических (конституционных) правил. Налаживание взаимосвязи между формальными и неформальными институтами становится обязательным условием принятия фрормальных норм общественностью, что обеспечивает эффективное воздействие фрормальных институтов. Корпорации, представляющие собой масштабные социальные группировки и обладающие значительными ресурсами, имеют исключительные возможности лоббировать собственные интересы.

Выполнение формальных правил обеспечивается действием традиций, обычаев, социальных условностей (неформальных ограничений), а при их недостаточности включаются механизмы принуждения, обеспечивающие выполнение правил. Политические правила устанавливают иерархическую структуру государства, определяют порядок принятия решений, фиксируют подходы к контролю за их соблюдением. Совокупность политических правил позволяет идентифицировать общество как целое. Конституционные правила существуют на всех организационных уровнях от государства к 
организации. Именно они обеспечивают формирование каркаса институциональной среды, в котором создаются мотивационные предпосылки и общие ограничения обмена. Экономические правила более низкого порядка структурируют процесс обмена между экономическими агентами. Например, такие правила определяют оптимальную фрорму организации хозяйственной деятельности, регламентирующие установление предельной цены на продукты и ресурсы, внедряют ограничения на импорт из-за квотирования и повышение таможенных платежей, усиливают экологические требования, меняют сроки действия патентов, определяют действенность мер антимонопольного регулирования, повышают требования к лицензированию [74, с. 128-131].

Независимо от подходов к оценке мотивов правительственных служащих разных уровней при принятии решений, выбор будет ориентирован на решение наиболее острых проблем общества. Задачей государства является создание системы институциональных структур различных уровней, которая должна обеспечить обоснованное вмешательство государства в рыночные механизмы для выполнения социальной функции.

Государство является наиболее универсальным гарантом выполнения контрактов, оно действует вместе с профессиональными, региональными и международными организациями. Государство - это организация, на эффективность функции которой влияют проблемы управления поведением исполнителя. В рамках «агентской проблемы» государственный служащий может использовать асимметрично распределенную информацию в свою пользу для обеспечения собственных интересов, не совпадающих с интересами поручителя. Рост размеров государства позволяет экономить на затратах при создании угрозы или совершении насилия. Одновременно это связано с дополнительным риском злоупотреблений, преимуществами выполнения функций гаранта обменов. Поведение гаранта зависит от стимулов: краткосрочные выгоды повышают вероятность злоупотребления гарантом своими преимуществами [74, с. 177-179]. 
Неэффрективное выполнение гарантом своих функций, прежде всего, неадекватность и неопределенность в применении санкций, может приводить к выбору субъектами хозяйствования другой формы гарантий (теневой арбитр, другое государство), сокращение экономической активности на данной территории, изменения фрормы деятельности (бездействие или имитация деятельности). Гарантом выполнения контракта может выступать другое государство, что приводит к частичной потери монополии государства на принуждение на своей территории. Международные организации также могут выступать гарантом государства, которое является членом организации. Другой институциональной альтернативой обеспечения выполнения правил является использование ценности репутации - бренд, внешний публичный аудит, бюро бизнеса будущего, рейтинговые агентства [74, с. 180-183].

Большая часть правил создается для обеспечения скорее частных, чем общественных интересов. Увеличение разнообразия интересов уменьшает вероятность обеспечения любого интереса за счет большинства, способствует возникновению сложных форм обмена, созданию коалиций [39, с. 69]. Производство определенных благ финансируется всем обществом, а через принятие различных программ потребляется лишь частью населения. Это приводит к появлению альтернативных программ с благоприятными последствиями для «потерпевшей» части населения и увеличению общественных расходов $[74$, c. 129$]$.

Государство начинает и поддерживает фрункционирование формальных институтов, необходимых для создания и функционирования национальной системы управления. Государственные фрормальные институты - Конституция, кодексы, законы, постановления, распоряжения имеют статус обязательных правил для части субъектов хозяйствования. Информирование субъектов хозяйствования происходит через создание нормативной базы законодательных актов - института права.

Контроль за соблюдением организациями государственных норм возложена на институты судебной и налоговой систем, институт 
аудиторов. Государственное воздействие на субъектов хозяйствования осуществляется также через дополнительные инструменты: лицензирование, квотирование, ассортиментное регулирования, ценообразования, антимонопольные ограничения, налоговые, кредитные и другие льготы. Структура налогов, акты государственного регулирования, судебные решения, законы и другие формальные ограничения определяют стратегические направления формирования политики корпораций и конкретные проявления экономического поведения [39, с. 142].

Государственное регулирование выходит за пределы непосредственно управления государственными корпорациями, создавая целостную организационно-правовую базу функционирования всех корпоративных предприятий. Государство устанавливает правила игры нормы, законы, определяющие возможности развития организаций. Выступая регулятором отношений между собственниками, менеджментом, наемными работниками, контактными группами, государство превращается в элемент корпоративной среды. Регулирующее влияние государства происходит непосредственно через систему общехозяйственных норм и нормативов, так и опосредованно через реализацию стратегий социальной ответственности организаций, регулирования деятельности других образований в пределах данного общества [18, с. 58].

Анализ особенностей функционирования национальных регулирующих систем позволил определить характер влияния государства на структуру собственности: сильная защита прав собственников приводит к распылению собственности; слабая - к концентрации корпоративной собственности и создания сложных систем контроля [59, с. 110]. Инсайдерская структура собственности, сложившаяся в Украине, свидетельствует о недостаточности институционального обеспечения процессов корпоративного развития.

Украинская экономика считается одной из самых открытых, что объясняется значительно меньшим, чем в развитых странах, вмешательством государства в управление экономикой. Открытость национальной экономики обеспечивает усвоение достижений мирового 
научно-технического прогресса, осуществления коренных изменений качественных характеристик национальной экономики, вхождения в мировую экономику. Одновременное усиление конкуренции со стороны конкурентоспособных зарубежных товаропроизводителей заставляет вводить ограничения принципов свободной торговли в те секторами экономики, которые имеют ощутимое преимущество. Правительства развитых стран за долгие годы функционирования рыночной экономики сумели создать действенную систему защиты и поддержки национального рынка.

Рыночная самоорганизация не в состоянии преодолеть институциональные, инвестиционные, финансовые кризисы и нуждается в государственном регулировании. Создание государственных институтов обеспечивается структуризацией неинституционализированной среды и легализацией неформальных институциональных норм [62, с. 11]. Несовершенство и фррагментарность существующего законодательства приводит к медленному формированию инфрраструктуры, неудовлетворительному выполнению принятых законов. В Украине отсутствуют государственные институты, способные аккумулировать все достижения нации на благо общества [16, с. 28].

Интенсификация экономического развития, переход к экономике знаний невозможны без участия государства. Уровень конкуренции в экономике тесно связан с деятельностью государства, зависит от того, насколько провозглашенная фрорма государства соответствует экономической основе власти, а конкурентная политика государства определяется взаимодействием двух факторов - конкуренции в бизнесе и политической конкуренции [8, с. 3]. Значительные негативные синергетические эффректы взаимодействия бюрократии и корпоративного бизнеса создали деформированную вертикаль власти для обеспечения интересов олигархии [62, с. 11].

Задачей государства является обеспечение государственной защиты конкуренции в предпринимательской деятельности, охрана прав и интересов предпринимателей от проявлений монополизма для решения 
проблем на рынках товаров и услуг. Эти задачи, основы которых составляет кейнсианская доктрина, выставляются украинским законодательством как предмет первоочередного внимания органов власти, прежде всего Антимонопольного комитета Украины. Однако, по мнению Дж. Гилберта, задачей государства должно стать не преодоление монополии, а снижение стоимости и риска использования технологий и фринансирования развития современной науки.

Самым влиятельным фактором формирования всех составляющих государственной политики становится обязательство власти перед собственным электоратом с его интересами. Экономически господствующая страта создает государство как аппарат принуждения для охраны своих экономических интересов. Государство, в свою очередь, фактически устанавливает фрормальные и неформальные институты, правила игры на экономическом поле, среди которых важнейшими являются условия конкуренции.

Модели конкурентной политики государства можно разделить на «сбалансированные» и «несбалансированные» в зависимости от вариантов соотношения политической и экономической конкуренции и соответствия состояний экономической и политической конкуренции друг другу [8, с. 3]. Модель «сбалансированного соотношения» включает три варианта: 1) государство ограничивает доступ к политической конкуренции своих антагонистов; 2) государство расширяет свою социальную базу и переносит на нее правила добросовестной политической конкуренции ради сглаживания противоречий и повышения уровня жизни населения; 3) государство устанавливает правила недобросовестной политической конкуренции для обеспечения власти узкого круга лиц, в конкурентной среде под прикрытием антимонопольного законодательства действуют фактические правила недобросовестной конкуренции.

Модель «несбалансированного соотношения» характеризует фактический разрыв между условиями реализации политического плюрализма и экономическими интересами власти, включая два варианта: 1) государство противостоит интересам экономически господствующих 
кругов и мешает бизнесу, который, в свою очередь, использует «грязные» технологии для лоббирования своих интересов, захват лидирующих должностей в государстве; 2) бизнес мешает государству, вызывает недовольство у руководства страны, которое, в свою очередь, путем уголовного преследования отстраняет от власти олигархов, перераспределяя их собственность [8, с. 3-4].

Методологическую основу формирования конкурентной политики Украины и антимонопольного законодательства составила концепция идеальной конкуренции, в которой не отображались эволюционные изменения в обществе: научно-технический прогресс, глобализация рынков, интенсификация процессов слияния и поглощения, образование мощных корпораций [23, с. 23]. Формирование конкурентной среды базируется на потребности государства в здоровой экономической конкуренции, которая заставляет нормально работать механизмы политического плюрализма. Эффективное функционирование предприятий В конкурентной среде требует обеспечения набора гарантий в сфрере экономического регулирования: равные возможности по защите прав, равный доступ к механизмам государственной поддержки, четкие правила игры [8, с. 4-5].

Влияние государства направлено не только на создание благоприятных условий для наднационального бизнеса с целью вовлечения национальных предприятий в мировое экономическое пространство. Целью государства может быть торможение и блокировка вхождения нежелательных для национальной среды предприятий. С этой целью используются формальные и неформальные институты: механизмы входных требований, каналов прямого отсева, прямого пропуска [48, с. 25].

Приоритетом деятельности органов государственной власти должна стать реструктуризация и повышение конкурентоспособности хозяйственных комплексов и отдельных крупных предприятий, расширение их отраслевой принадлежности, экологизации производства, развитие производственной, транспортной и рыночной инфраструктуры [44, с. 8].

В процессе трансформации институтов государство выступает как 
законодатель и как гарант соблюдения законов. При обеспечении социальной справедливости достаточно четко отслеживается противоречие между формальным и неформальным институтами: государство не может реализовать социальные функции в соответствии с законодательно установленными требованиями. Государство, конституционно определив социальную направленность развития экономики, должно обеспечить создание соответствующих институтов для реализации социальной конверсии.

Необходимо признать, что политические решения критически влияют на функционирование экономики. Учет этого влияния требует создания модели политико-экономического процесса, составляющими которого становятся институты, связанные с этим процессом, и, опирающаяся на эти институты, структура политического и экономического взаимодействия.

\section{4. Институциональные изменения конкурентной среды} трансформационной экономики

В условиях глобализации чрезвычайно актуализируются проблемы разработки мероприятий по укреплению конкурентоспособности организаций как основы обеспечения устойчивых позиций Украины на мировом рынке. Глобальные особенности и проблемы развития организаций, приобретают системный характер, порождают принципиально новые тенденции в функционировании и регулировании конкурентной среды.

Методы управления конкурентоспособностью выбираются в зависимости от особенностей институционального развития составляющих конкурентной среды компании. Конкурентная среда определяет уровень и структуру конкуренции, условия рыночной конкуренции и устанавливает систему действий организации на рынке. Тенденции развития конкурентной среды формируются через совокупное действие и взаимодействие ее элементов. Самые значительные среди них - процессы глобализации и кризисные процессы - меняют все составляющие 
конкурентной среды, сопровождаются повышением конкурентного давления, прежде всего вследствие снижения эфрфективности хозяйственной деятельности и уменьшение объемов рынка. Рынок оставляют небольшие локальные товаропроизводители, а конкуренция переходит из регионального в национальный и межнациональный уровне.

На функционирование всех элементов конкурентной среды организаций в значительной степени влияет важнейший процесс современной экономики - глобализация. Глобализация экономики изменяет сущность конкурентоспособности, которую традиционно связывают с внутренними свойствами национальных экономических систем, и изменяет восприятие роли мирового хозяйства как надсистемы. В рамках международного экономического пространства как стратегического ресурса развития формируются глобальные доходы, собственность, рента и квазирента (сверхприбыли), которые распределяются по принципу уровня конкурентоспособности [48, с. 231].

Характеристики международной экономической конкуренции определяют направления и интенсивность изменений внутреннего рынка национальных государств. В условиях глобализации возникла сложная трехэлементная структура международного бизнеса, в рамках которой организация конкурирует на рынке страны с местными предприятиями; ведет борьбу с мультинациональными корпорациями; мультинациональные корпорации, в свою очередь, конкурируют между собой $[11 ; 17$, с. $85 ; 32$, с. 17].

Конкуренция, как и любой институт рыночной экономики, переживает трансформацию. Процессы транснационализации капитала меняют формы и методы конкурентной борьбы, заставляя предприятия усиливать конкурентоспособность товаров и фирм на национальном, так и на международном рынке. Дж. Гилберт вообще исключал корпорации из конкурентного процесса. Ученый считал, что законы рынка действуют в так называемом рыночном секторе малого бизнеса, а крупные корпорации планирующий сектор - подготавливают внешнюю среду в соответствии со своими потребностями [12]. 
Конкурентную среду организации целесообразно разделить на внутреннюю и внешнюю $[1,3 ; 13$, с. $84 ; 26$, с. 59-67; 46; 51] и можно представить в виде трехслойной структуры: внутренняя и внешняя функциональные среды и внешняя генеральная среда. Внутренняя среда включает внутрифирменные элементы предприятия: работников, менеджмент, корпоративную культуру. Элементы внешней среды находятся за пределами предприятия, однако влияют на результаты работы компании. Организация оперирует непосредственно в функциональной среде задач, с элементами которого - конкурентами, поставщиками, рынком труда, потребителями - связано большинство ее ежедневных фрункций. Общая генеральная среда охватывает технологическую, социокультурную, экономическую, законодательную, политическую, международную составляющие, опосредованно и примерно одинаково влияют на деятельность всех предприятий [13, с. 84].

Каждая из составляющих конкурентной среды компании, направление и сила воздействия которых определяют характер отраслевой, национальной и глобальной конкуренции, отражают специфический вид отношений, взаимосвязей и взаимодействия организации на рынке.

Организации на рынке отличаются уровнем способности удовлетворять потребности потребителей и участвовать в конкурентной борьбе - конкурентоспособностью. Конкурентоспособность организации системное свойство, структурирующее конкурентную позицию предприятия на внутренних и внешних рынках и обеспечивающее ее жизнеспособность как субъекта глобальной экономической деятельности. Это свойство связано с умением достигать конкурентных преимуществ. Экономические, технические, организационные, научные преимущества предприятия перед конкурентами, которые можно измерить количественно, - это конкурентные преимущества, проявляющиеся через дополнительные объемы, повышение рентабельности, рыночной доли объемов [58, с. 66].

Источником конкурентных преимуществ является ценность эксклюзивная характеристика, которой владеет система, и реализация 
которой дает системе преимущество над конкурентами [67, с. 120]. Ценности могут быть материальными, нематериальными, денежными, социальными, культурными, духовными, природными, политическими. Например, здоровье, талант, профессионализм, нововведения, торговая марка, низкая себестоимость, высокая квалификация персонала и тому подобное. Ценности могут касаться любой стороны деятельности предприятия и быть достаточно разнообразными по формам проявления (табл. 1).

Источником глобализации является стремление корпораций преодолеть конкуренцию законным созданием супергигантов, стремящихся к монопольному положению уже в рамках мировой экономики. Эволюционные изломы во взглядах ученых на методологические основы конкурентоспособности и формирования конкурентной политики кардинально изменили понимание роли монополии в развитии конкурентной среды. Ученые опротестовывают традиционные взгляды неоклассиков и марксистов на монополию как препятствие конкуренции в рамках национального хозяйства, что требует ограничения деятельности через антитрестовское законодательство. Монополия признана основным субъектом международной деятельности, что позволяет решать проблемы обеспечения конкурентоспособности и повышения эффрективности производства путем восстановления высокого уровня концентрации производства [54, с. 48].

Последние исследования ученых-экономистов показывают итоговую положительную динамику монопольного производства, обосновывают влияние монополии на повышение эффективности производства и обеспечения конкурентоспособности. Основным средством повышения конкурентоспособности и эффективности национального хозяйства при проведении структурных преобразований служит именно восстановление высокого уровня концентрации производства и отмены традиционного антитрестовского регулирования. Создание корпораций путем ускоренной концентрации капитала через слияния и поглощения способствовало усилению международных позиций западных экономик. 
Классификация ценностей корпорации

\begin{tabular}{|c|c|}
\hline Классифрикационный признак & Разновидность ценности \\
\hline форма учета & $\begin{array}{c}\text { материальные } \\
\text { нематериальные } \\
\text { денежные } \\
\text { культурные } \\
\text { духовные }\end{array}$ \\
\hline характер влияния & $\begin{array}{c}\text { социальные } \\
\text { экономические } \\
\text { организационно-структурные } \\
\text { технологичные } \\
\text { имеджевые } \\
\text { демографически } \\
\text { географические } \\
\text { нормативно-правовые } \\
\text { природноклиматические } \\
\text { политические }\end{array}$ \\
\hline источник происхождения & $\begin{array}{c}\text { внутренняя среда } \\
\text { внешняя среда }\end{array}$ \\
\hline степень влияния организации & $\begin{array}{c}\text { вне сферы влияния } \\
\text { организации } \\
\text { в сфрере влияния организации }\end{array}$ \\
\hline $\begin{array}{c}\text { субъект-инициатор возникновения ценностей } \\
\text { организации }\end{array}$ & $\begin{array}{c}\text { внешняя среда } \\
\text { внутренняя среда }\end{array}$ \\
\hline продолжительность действия & $\begin{array}{l}\text { долгосрочные } \\
\text { среднесрочные } \\
\text { краткосрочные } \\
\end{array}$ \\
\hline уровень иерархии & $\begin{array}{c}\text { товар } \\
\text { фирма } \\
\text { регион } \\
\text { отрасль } \\
\text { национальная экономика } \\
\text { глобальная экономика } \\
\end{array}$ \\
\hline сфрера проявления & $\begin{array}{c}\text { поставщики } \\
\text { потребители } \\
\text { рынок труда } \\
\text { конкуренты } \\
\text { проектирование } \\
\text { производство } \\
\text { реализация } \\
\text { сервис и эксплуатация }\end{array}$ \\
\hline возможность имитации & $\begin{array}{c}\text { уникальные } \\
\text { имитационные }\end{array}$ \\
\hline характер участия в производственном процессе & $\begin{array}{c}\text { ценовые } \\
\text { неценовые }\end{array}$ \\
\hline динамика & $\begin{array}{c}\text { стойкие } \\
\text { нестабильные }\end{array}$ \\
\hline
\end{tabular}


Правительства национальных государств и руководство ЕС считает повышение уровня концентрации положительным явлением, меняет форму конкуренции путем усовершенствования методов производства, качества и ассортимента продукции [23, с. 21-22].

В глобальной экономике происходят процессы, противоположные конкурентным. Прослеживаются две тенденции, которые исключают друг друга: усиление конкурентной борьбы за увеличение количества товаропроизводителей и рост кооперации между структурными подразделениями корпораций для выполнения отдельных видов работ (например, научные исследования, конструкторские работы, лоббирование интересов). Повышение трансакционных издержек международных операций требует достижения синергетического эффректа управления для их возмещения. Рост трансакционных издержек вследствие разукрупнения приводит к тенизации и бартеризации экономики как средствам снижения затрат [23, с. $25 ; 48$, с. 24].

В разных странах установлены различные значения доли рынка, по которым определяют доминирующее положение: в России для одного предприятия - 65\%, если оно не докажет свое недоминантное положение, и от 35\% до 65\%, если это установлено антимонопольным органом; в Германии для одного предприятия - 33\%, для двух - 50\%, для трех - 66\%; в Японии для одного предприятия - более 50\%, для двух - не более 75\%; в Великобритании и Франции - 25\% [30, с. 106].

Фактором повышения конкурентоспособности страны, организации и продукции становится инновационное развитие. Изменения структуры мировой торговли последней четверти XX в. привели к увеличению доли высокотехнологичной и наукоемкой продукции, значительному уменьшению доли товаров первичной обработки и сырья, что актуализирует внедрение инноваций в организационно-производственную политику корпорации [35, с. 164-165]. Значение научно-технического прогресса как основного фактора конкурентоспособности предприятия является общепризнанным. Внедрение нововведений становится ключевым фрактором рыночной конкуренции и позволяет передовым 
корпорациям получать сверхприбыли от интеллектуальной ренты за счет монопольного использования инноваций [10; 36].

Способность создавать новые технологии и высокотехнологичные продукты, обеспечивает технологический отрыв от конкурентов и становится основным конкурентным преимуществом [6, с. 68]. В начале XXI века акцент от конкурентной борьбы смещается на конкурентное сосуществование предприятий. Интенсивность изменений в конкурентной среде делает недолговечной любое конкурентное преимущество, то есть создание конкурентных преимуществ должно быть поставлено на поток, инновации должны сменять друг друга, что достигается путем интеграционных соглашений между субъектами экономики [8, с. $\left.{ }^{\circ} 4\right]$.

Сфрера корпоративного сектора интенсивно развивает и влияет на динамику технологического знания в соответствии с конкурентной средой, а сорера действия малого бизнеса адаптирует уже имеющиеся технологические знания в конкурентной среды и внедряет технологии. Технологические знания накапливаются и реализуются в виде новых технологий преимущественно крупными корпорациями, а их недостаточное развитие в Европе может объяснить феномен «европейского парадокса». Отсутствие национальных крупных корпораций приводит к выводу инновационных процессов за пределы страны, когда академические научные знания трансформируются В технологии иностранными корпорациями без всякой выгоды для национальных товаропроизводителей [34, с. 83-84].

Современные тенденции корпоративного развития меняют взгляды на роль организации в рыночном процессе. Сильная конкуренция формирует условия для еe ограничения, a конфликтное противопоставление рыночных субъектов, каждый из которых имеет собственную цель, порождает монополию. Корпорации сами создают потенциальный спрос на новую продукцию, разрабатываемую на предприятии, формируя потребность и даже традиции. Аргументацию неоклассики об общественной неэффективности размещения ресурсов при значительной рыночной власти отдельных фрирм, приемлемой для 
стационарной экономики, опровергает фрактор научно-технического прогресса в динамичной экономике [23, с. 20]. Ученые связывают конкурентоспособность и инновации, определяя конкурентоспособность страны как способность генерировать и быстро осваивать научные, технологические, промышленные, организационные инновации [44, с. 6; 72, c. 85].

Информационно-технологические изменения привели к появлению новых форм конкурентной борьбы путем объединения предприятий в крупные хозяйственные комплексы, деятельность которых охватывает национальное и наднациональное пространство. Одновременно происходит усиление конкуренции между мировыми экономическими центрами, государствами и транснациональными корпорациями и становится острее внешняя конкуренция за долю национального рынка [7, c. $28 ; 68$, c. 26$]$.

Глобальная конкуренция ведется между транснациональными системами, объединяющими национальные системы образования, накопленный капитал, организацию науки, предпринимательские и финансовые структуры. Несколько таких систем, плотно взаимосвязанных, формируют ядро мировой экономической системы, концентрируют интеллектуальный, технический, предпринимательский и фринансовый потенциал и определяют глобальное экономическое развитие [10].

Основную массу расходов на научно-исследовательские и проектноконструкторские разработки осуществляет корпорация. Технический прогресс соответствует двум основным целям корпорации: уменьшение расходов и установление конкурентоспособной цены увеличивает объемы продаж и, соответственно, рост доходов; укрепляет власть, обеспечивает и защищает менеджмент. Технический прогресс выполняет еще одну функцию - сопровождает вытеснение капиталом труда, единого производственного фактора, не полностью попавшего под контроль корпорации [12, с. 67-68].

Корпорации, обладая колоссальными производственными и финансовыми ресурсами, производят высокотехнологичные изделия и 
наукоемкую продукцию и, как следствие, контролируют более двух третей основных потоков научно-технологических знаний. По версии журнала Fortune, компании из Global Innovation 1000, в прошлом году инвестировали рекордные 647 миллиардов долларов. Самыми инновационно емкими отраслями являются: автомобильная (Volkswagen в 2013 году потратил на инновации 13,5 млн. дол, Toyota - 9,1 млн. дол), ИТиндустрия (Intel - 10,6 млн. дол, Microsoft - 10,4 млн. дол, Google - 8 млн. дол, Samsung - 13,4 млн. дол), медицина (Roche - 10 млн. дол, Novartis 9,9 млн. дол, Johnson\&Johnson - 8,2 млн. дол, Merck - 7,5 млн. дол).

Корпорации перешли к непрерывному инновационному процессу в практике управления, охватив весь производственный цикл от инвестирования до реализации инновационной продукции. Такая позиция обеспечивает лидерство развитых стран из-за роста роли индустриальноинфрормационных отраслей.

Прирост ВВП развитых стран на 70-85\% обеспечивается новыми знаниями, воплощенными в новых технологиях [10].

Передовые позиции развитых стран достигаются увеличением интенсивности НИОКР, на которые государства выделяют не менее 2,5\% ВВП. Страны - инновационные лидеры фрормируют контуры новых технологических укладов и используют все преимущества монопольного положения. Доступ других стран к новым технологиям происходит на основе неэквивалентного обмена.

Ведущие корпорации и страны навязывают удобные и выгодные им правила обмена инноваций на природные ресурсы или дешевый труд. Однако использование методов конкуренции достаточно диффреренцированное в зависимости от страны-товаропроизводителя.

Высокоразвитые страны используют технологические преимущества для создания все более сложных и высококачественных продуктов.

Слаборазвитые страны могут использовать как конкурентные преимущества только ценовую конкуренцию за дешевые природные ресурсы, предельное снижение оплаты труда и затрат на обработку сырья.

Отличаются и последствия. Корпорации развитых стран захватывают 
новые рынки, увеличивают доходы от экспорта и национальный ВВП, повышают качество жизни; снижают доходы от экспорта и доходы населения, теряют человеческий капитал. Опережающее создание инноваций требует колоссальных затрат на НИОКР, недоступных слаборазвитым странам [6, с. 68-69; 42, с. 50].

Происходящее в Украине резкое сокращение фундаментальных исследований, недофинансирование прикладных разработок, уменьшение объемов производства наукоемкой продукции составляет серьезную преграду на пути к конкурентоспособной национальной экономики. Страны, развивающиеся на инновационной основе, тратят на нужды науки не менее 2,5\% ВВП. Две страны мира - Южная Корея и Израиль - тратят на исследования и разработки более 4\% ВВП. По данным Евростата в 2003 и 2013 расходы на науку в процентах к ВВП составляют соответственно: в Южной Kopeе - 2,35\%, 4,15\%; EC - 3,14\%, 3,4\%; США - 2,55\%, 2,77\%; Япония - 1,8\%, 2,03; Китай - 1,13\%, 2,08\%; Украина - 1,06\%, 0,7\%. В 2015 году этот показатель в Украине снизился до 0,62\%.

Определяющей тенденцией развития конкурентной среды В корпоративной экономике становится «интеграционный экспансионизм» с выраженной доминантностью метрополий. Этот процесс обеспечивает эффрективный контроль за ресурсами и создание международнокооперационного пространства, на базе которого развивается массовое и специализированное производство [37; 38, с. 10]. В международных экономических цепочках с международным разделением труда на базе аутсорсинга, слаборазвитые страны занимают сектор массового производства стандартизированной продукции, тогда как в развитых странах располагаются НИОКР, наукоемкие производства, банки [6, с. 68]. Освоение корпорациями отдельных сегментов национального рынка затрагивает интересы различных стран, порождает противостояние и даже конфликты [48, с. 24].

Актуализация новых сфер социально-экономической деятельности приводит к «дематериализации» ресурсов. Конкурентная борьба переносится в ранее неконкурентные сферы, такие как информационное 
пространство, человеческие ресурсы. Научно- и информационно емкие воспроизводственные системы отражают современное представление о богатстве государства. Некоторые авторы связывают увеличение доли интеллектуально и информационно емкой продукции в структуре экспорта США со стремлением достижения мирового лидерства. Именно такие меры, а не максимизация экспорта, становятся элементами диверсифицированного инструментария в рамках стратегии развития международной торговли. Корпорации замыкают важные технологические циклы на своих предприятиях, контролируемых корпоративным капиталом, но могут быть расположены за пределами материнской страны [38, с. 5-9].

Корпорации, сохраняя традиционные мотивационные стимулы к инвестированию, такие как новые рынки, дешевая рабочая сила, национальная ресурсная база, лояльное законодательство, стремятся делать капиталовложения в динамические высокотехнологичные кластеры стран-лидеров или в национальные экономики отсталых стран, обладающих стратегическими нематериальными ресурсами экономического развития (инновационная и социальная инфраструктура, способность к продуцированию технологических новаций и непрерывному обучению сотрудников) [61, с. 126]. Предпочтительными и практически единственными направлениями инвестирования корпораций в экономику развивающихся стран, так называемую «глобальную периферию», становятся: а) производства, обслуживающие собственные нужды производственной деятельности корпорации; б) производства, не требующие значительных информационных и высококвалифицированных человеческих ресурсов («стратегически бесплодное производство»); в) экологически и технологически вредные производства, что позволяет сэкономить средства на мероприятия технологической и экологической безопасности и поддержание имиджа корпорации [61, с. 5-6].

Лучшим источником фринансирования инноваций считают прямые инвестиции, принцип максимизации которых на макроуровне ограничен двумя фракторами. Во-первых, превышение количества инвестиций над максимально допустимым к усвоению экономикой вызывает инфляционное 
давление. Во-вторых, предпочтительными, и практически единственными, направлениями инвестирования корпораций в экономики стран «глобальной периферии» является стратегически бесплодные и вредные производства [29; 38, с. 5-6; 43, с. 5].

«Иностранный капитал приносит устаревшее оборудование и технологии вчерашнего дня», не ликвидируя технологическую отсталость и не сокращая технологический разрыв между странами. Превышение оптимального предела прямых иностранных инвестиций ведет к установлению полного контроля корпорацией над странами [6, с. 72]. Эти факторы вместе с ограничением максимально возможного к усвоению количества инвестиций из-за роста инфляционного давления становятся препятствием для прямых инвестиций как лучшего источника финансирования [38, с. 5-6].

Важнейшим ресурсом и ограничительным фрактором развития предприятия сегодня являются знания и интеллект, а не природные ресурсы или капитал. Растет роль человеческого фрактора в организации корпоративного производства. Страны, не способные обеспечить необходимый уровень образования и квалификации, будут оставаться источником сырья и человеческого материала для корпораций развитых стран, концентрирующих глобальный интеллектуальный потенциал. Исследования Г. Беккера, Т. Шульца, Дж. Минкера доказывают необходимость и эфрфективность крупных инвестиций в человеческий капитал, что обеспечит значительные прибыли корпорациям и обществу [66, c. 15-20].

Именно Украина имеет фрактор конкурентных преимуществ человеческий капитал, то есть высококвалифицированных работников, которые обладают достаточными знаниями для использования сложных технологий и анализа информации, способны к созданию принципиально новых технологий, высокотехнологичных продуктов, новых форм производства и реализации этих продуктов. Использование снижения цены за счет уменьшения заработной платы, как единственного метода конкуренции на украинских корпорациях, ведет к прямому хищения 
человеческого капитала [6, с. 68-69].

Направления изменений характера отраслевой и глобальной конкурентной среды позволяют определить главные принципы, на которые должна опираться деятельность по достижению конкурентных преимуществ, и методы обеспечения конкурентоспособности предприятия (табл. 2).

Таблица 2

\section{Принципы и методы обеспечения конкурентоспособности, основанные на развитии институциональной среды}

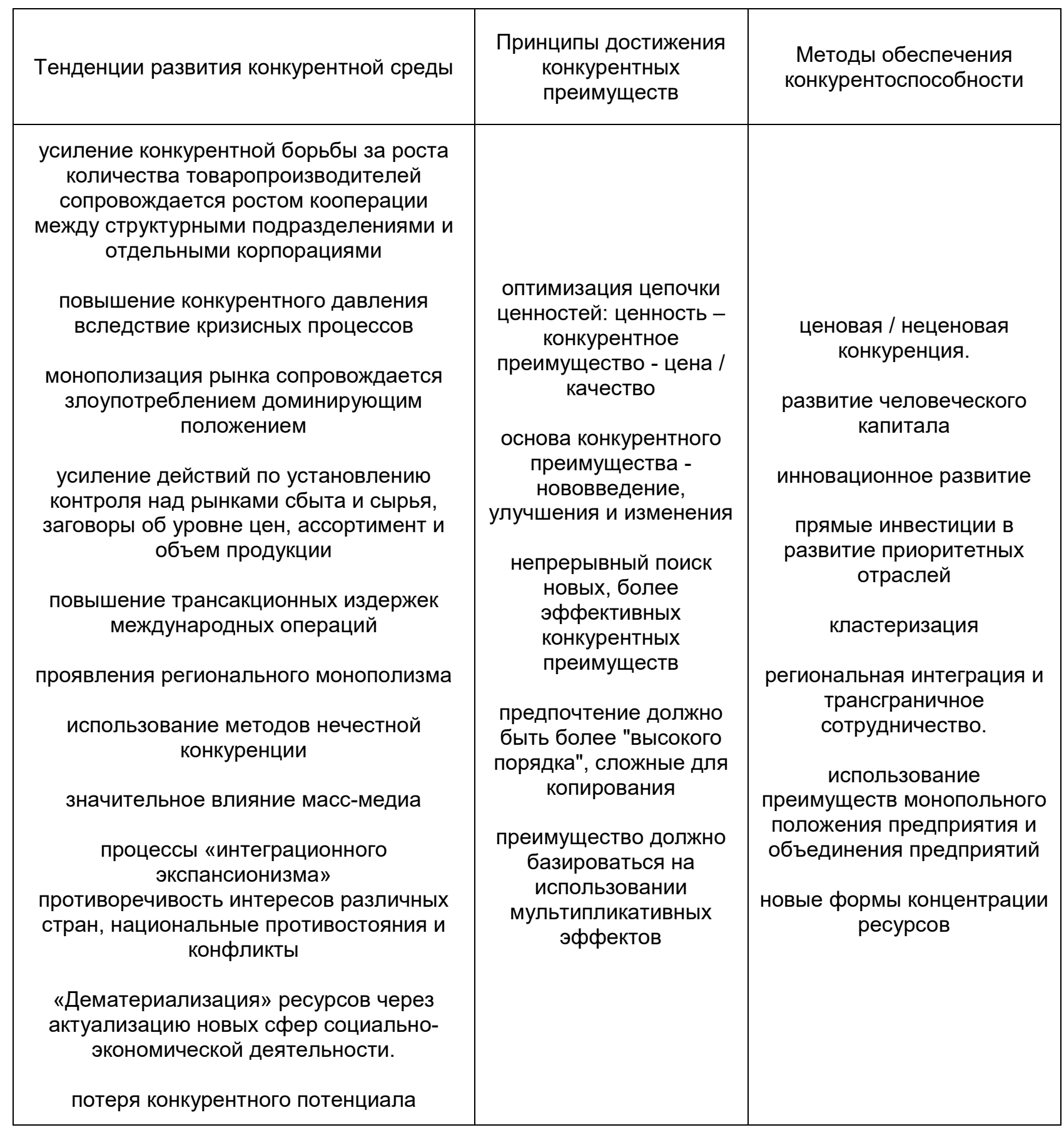


Основой противодействия конкурентам и выживания организации в долгосрочной перспективе становятся конкурентные преимущества, достижение которых должно базироваться на принципах, которые становятся основой для формирования методов конкурентной борьбы:

1. Конкурентное преимущество связано с оптимизацией цепочки ценностей, в начале которого находится ценность, а в конце конкурентоспособная цена или конкурентоспособное качество. Конкурентное преимущество имеет относительный характер, поскольку определяется через сопоставление одинаковых характеристик различных организаций. Конкурентные преимущества могут быть любого качества как объективные условия институциональной среды, так и условия деятельности отдельных компаний.

2. Основой конкурентного преимущества должны быть нововведения, улучшения и изменения. Внедрение инноваций не связано с отраслевой принадлежностью производителя.

3. Поддержка достигнутых преимуществ происходит путем непрерывного поиска других, более эффрективных. Конкурентное преимущество имеет относительный характер, поскольку оценивается путем сопоставления одинаковых характеристик товаров различных фрирм.

4. Конкурентное преимущество неуниверсальное, зависящее от конкретных условий, подвергается воздействию совокупности фракторов, которые могут ее усилить или ослаблять.

5. Преимущества должны быть «высокого порядка», то есть сложные для копирования, обеспечивающие долговременное действие (подготовленные человеческие ресурсы и внутренние технические возможности).

6. Конкурентное преимущество должно базироваться на использовании мультипликативных эффектов.

Важным направлением в этом контексте должна стать государственная политика в области управления инновациями на основе применения отраслевых принципов с обеспечением соответствия мер государственного регулирования национальной стратегии научно- 
технического и инновационного развития. Внешний контур регулирования должен производить адекватные состояниям внешней среды и национальной экономики методы и средства регулирования конкурентоспособности отраслей и предприятий; определять наиболее целесообразный способ горизонтального взаимодействия субъектов национальной экономики; формировать набор методов регулирования конкурентоспособности.

Основные векторы развития экономики заключаются в структурной перестройке экономики с переходом от сырьевого производства к производству конкурентоспособных товаров потребления; формировании отечественного сектора информационно-индустриальных отраслей, созданных объединениями корпоративных и малых предприятий. Необходимым условием стабильного и динамичного экономического роста является синтез систем управления конкурентоспособностью с механизмами активного противодействия влиянию негативных внешних факторов, реализуется через сочетание эффрективной конкурентной политики и системы антимонопольной защиты национальной экономики.

Существует взаимосвязь между процессами транснационализации корпоративного капитала и изменениями фрорм и методов конкуренции. Важнейшими факторами формирования институциональной среды являются глобализация, инновационные процессы и изменения в теоретических подходах и практических аспектах конкуренции. основным средством повышения конкурентоспособности и эфффективности национального хозяйства является восстановление высокого уровня концентрации производства при проведении структурных преобразований на основе взвешенного антимонопольного регулирования как результат итоговой положительной динамики монополии корпораций. Необходимым условием стабильного и динамичного экономического роста экономики Украины становится нахождение оптимального соотношения между высоким уровнем корпоратизации экономики и созданием конкурентной среды с обязательной законодательно-регуляторной поддержкой.

Принципы достижения конкурентных преимуществ основываются на 
определении направлений изменений характера отраслевой и глобальной конкурентной среды. Они становятся основой для формирования методов конкурентной борьбы, таких как использование ценовой и неценовой конкуренции, развитие человеческого капитала, инновационное развитие, прямые инвестиции в перспективные отрасли, кластеризация мировой экономики, региональная интеграция и трансграничное сотрудничество, ориентация корпорации на монополизацию рынка, потребность в новых формах концентрации ресурсов

\section{5. Глобальная институционализация экономики}

Активизация процессов глобализации определяет ключевую роль этого феномена, влияющего на внутреннюю жизнь любой страны. Глобализация стала неисчерпаемым источником социальных и экономических новаций, основанных на возможностях организаций. Результатом глобального взаимодействия корпораций становится международное сотрудничество, ускорение динамики движения международных потоков капитала, информации, ресурсов, товаров, людей; повышение скорости международного обмена наукоемкими технологиями и знаниями; развитие мировой инфраструктуры, позволяющие решать самые насущные проблемы национальных государств. Одновременно глобальные трансформации усиливают и углубляют противоречия мировой экономики. Рост корпоративного влияния определяет основные направления процесса институционализации глобальных экономических отношений.

Позиционирование Украины в глобальном пространстве заключается в нахождении «своего места», что позволит эфффективно использовать преимущества интеграции корпораций в мировую экономику и выравнивать межнациональные противоречия.

Глобальная интеграция приобретает различные институциональные формы: международные региональные торговые блоки, международные межправительственные

организации, международные 
неправительственные организации, международные фринансовые и денежно-кредитные организации, международные отраслевые организации, сырьевые картели, единую валюту. Современная глобализация экономики происходит по трем взаимосвязанным направлениям: интеграция отдельных предприятий, региональная межстрановых интеграция, создание глобальных институтов.

Участие в политических и экономических союзах способствует образованию новых корпораций или участия в международных корпоративных объединениях. Существенное влияние интеграционных объединений на состояние и развитие глобальной экономики предопределяет использование особых наднациональных институтов регулирования глобальных процессов и деятельности глобальных объединений. В глобальной экономике возникает потребность в наднациональных органах, способных принимать оперативные решения от имени группы в целом. Правительства согласовано отказываются от части своих функций и тем самым уступают часть государственного суверенитета в пользу негосударственных органов. Важнейшими глобальными институтами, с которыми взаимодействует Украина, стали OОН, ВБ, ЕБРP, CE, ОБСЕ, МВФ.

Несостоятельность собственного слабого финансового сектора к кредитной активности для обеспечения развития государства финансовыми ресурсами вынуждает обращаться за помощью к международным организациям. Сбалансированная трактовка сущности глобализации показывает как ее новые возможности, так и вызванные ею недостатки. Последствия глобализационных процессов неоднозначно оцениваются различными учеными и политиками. Интенсивность и направленность влияния глобализационного влияния и результаты глобализации существенно отличаются в разных странах, отраслях, компаниях $[16$, с. $28 ; 20$, с. $49 ; 56$, с. $28 ; 60$, с. $46 ; 63$, с. $199 ; 73$, с. 37$]$.

Процессы слияния промышленных предприятий и поглощения одних предприятий другими стали самыми распространенными явлениями глобальной экономики, наиболее характерными для периодов подъема как 
отдельных стран, так и мировой экономики. Начало процессов слияния и поглощения в 60-е гг. $\mathrm{XX}$ в. связывают с различными факторами: случайное стечение обстоятельств; изменения в относительных ценах; потребность в защите от оппортунистического поведения менеджеров; технологические фракторы. По оценке Дж. Гилберта в начале 1970-х гг. экономика США состояла из двух частей. Половину экономики составляла «кучка» гигантских корпораций, руководители которых количественно теряются в университетской аудитории. Другая половина - 12 млн. мелких фирм плюс неучтенное количество нелегальных предприятий частнопредпринимательской экономики [12]. Сто крупнейших американских корпораций обеспечивают $60 \%$ ВВП страны, $45 \%$ рабочей силы, $60 \%$ инвестиций [35, с. 91].

Зачисление страны к категории «развитая» осуществляется по критериям «производство ВВП» и «производство ВВП на душу населения» [20, с. 48; 49, с. 31]. «Глобализационная чувствительность» экономики страны определяется по трем критериям [47, с. 269]:

- уровень внешнеэкономической открытости (внешнеторговый оборот, объемы экспорта и импорта, отношение этих показателей к ВВП)

- степень зависимости национальной экономики от деятельности многонациональных корпораций (удельный вес продукции (капитала) таких корпораций в ВВП (структуре собственности) страны);

- степень интегрированности национальной экономики, государственных управленческих институтов в международные союзы, ассоциации, альянсов и т.д.

Процесс глобализации приводит к появлению международных производственных цепочек ТНК с новой системой международного разделения труда. В развитых странах сосредотачиваются научноисследовательские предприятия, органы маркетинга и управления, банки и финансовые учреждения; в развивающихся странах - предприятия с низким организационно-технологическим уровнем для обеспечения массового производства стандартизированной продукции [6, с. 68; 23, с. 25]. Международная специализация стран, усиленная процессами 
интеграции, становится еще одним фактором углубления диспропорций развития стран [41].

Глобализация корпоративной экономики, не предотвращая системные кризисы, меняет их сущность и распространяет негативные явления на все большее количество стран. Усиление кризисных процессов в глобальной экономике обусловлено характерными чертами и основными проявлениями глобализации:

- интернационализация;

- технологизация;

- расширение торговли, ее либерализация;

- монополизация рынка;

- диффреренциация развития стран;

- капитализация;

- повышение давления на экологию;

- финансализация, увеличение оборотов капитала;

- процессы слияния и поглощения;

- кризис института государства;

- нивелирование национально-государственных отличий страны;

- локализация положительного эффекта;

- хронические и усиливающиеся дисбалансы финансовой системы;

- появление глобального человека-работника;

- совместное решение глобальных проблем.

Трансформации глобальной экономики определяют специфические проявления, глубину и продолжительность кризисных явлений и причины, их порождающие. Проявлением глобализации является стремительное распространение кризисных явлений в мировой экономике [28]. Источник проблем заключается в циклическом характере и общих закономерностях развития глобальной капиталистической экономики как результата накопления и перераспределения корпоративного капитала [57].

Современные подходы рассматривают кризис не только как временное затруднение для хозяйствующих субъектов, но и как трамплин в будущее, в новый технологический уклад. Технологические уклады 
представляют группы технологических совокупностей, связанные однотипными технологическими цепями и образующие воспроизводственные целостности. Долгосрочное экономическое развитие представляет собой процесс последовательного замещения технологических укладов. Сигналами о начале замещения доминирующего технологического уклада служат резкое повышение цен на энергоносители и сырье, и высвобождение капитала. Снижение относительной эффрективности капитала заставляет владельцев сокращать вложения в доминирующий технологический уклад и обеспечивает аккумулирование капитала, который ищет сферу применения. Происходит постепенное переливание уволенного капитала в новые технологии нового технологического уклада. Истощение возможностей роста технологического уклада приводит к появлению избыточных капиталов на финансовом рынке. Эти капиталы становятся основой массового внедрения новых базовых технологий [9].

Последовательная смена организационных фрорм интеграции связана с изменениями технологических укладов и формами концентрации капиталов для обеспечения инвестиционно-инновационных потребностей. Дальнейшие организационные преобразования организаций в шестом технологическом укладе связанные с необходимостью поиска новых форм корпоративного взаимодействия.

Неопределенность траекторий развития новых технологий и конкуренция различных инноваций провоцирует высокую рискованность инвестиций и создает благоприятные условия для финансовых спекуляций и махинаций. Безжалостным инструментом концентрирования доступных капиталов в новых технологиях становится "фринансовый пузырь". Крах "финансового пузыря" вызывает обесценивание капитала, но постепенно способствует переориентации инвестиций на реальные активы, обеспечивает выход из депрессии за счет развития новых отраслей. Пионерами этих отраслей становятся корпорации, обладающие достаточным количеством ресурсов. Закономерностями долгосрочного развития является тенденция к снижению конкуренции в конце жизненного 
цикла и формирование глобальных монополий.

Взаимосвязь событий на мировом финансовом рынке провоцирует глубину влияния этого процесса на национальные экономики. Отказ от структурной, промышленной, инвестиционной политики и подражания принципов ультралиберализма привела к нарушению основных воспроизводственных контуров экономики. Не оправдались надежды на рыночное регулирование мировой финансовой системы, обеспечивающей круговорот капитала, функционирующего через валютные, фринансовые и кредитные рынки. По мнению теоретиков-неолибералов, мировая финансовая система должна была автоматически направлять фринансовые средства по месту наибольшей потребности. Зато глобальная фринансовая система усугубила диффреренциацию стран, привлекая основную часть финансовых средств в развитые страны, и лишила капитала периферийные страны в соответствии с собственными корпоративными интересами.

Анализ развития глобализационных процессов позволяет спрогнозировать дальнейшие тенденции глобализации [52, с. 105-109]:

- дальнейшая локализация положительных эффректов глобализации, перераспределение качества жизни в пользу отдельных стран и народов, массовая передача негативных последствий глобализации (социальных, культурных, морально-психологических) в страны «третьего мира»;

- рост роли стран «ядра», включающий США, Японию, страны Европы вследствие локализации инвестиций, ресурсов, технологий в ведущих странах;

- одновременное усиление глобального и локального характера социально-экономических процессов;

- изменение мировых стран-лидеров вследствие мирового кризиса;

- усиление процессов транснационализации и капитализации;

- интенсификация развития интеллектуальной собственности как основы роста национального богатства;

- усиление угрозы мировой стабильности со стороны стран «третьего» мира, которые «... не проявляют никакого экономического 
прогресса и не способны обеспечить даже на своей территории ... порядок»;

- усиление религиозной розни, социально-этических конфликтов;

- концентрация на рынках развитых стран, установления контроля над прибыльными сфрерами деятельности для получения сверхдоходов от владения монопольной рентой;

- рост глобальной зависимости корпораций и глубины их интеграции, сокращение объема и уменьшение роли традиционной фрормы международной коммерческой торговли и усиления товарообмена в рамках корпорации. По концепции «периферийной экономики» мировая торговля представляет собой модернизированную форму осуществления непротекционистской политики мощными государствами мира, лишая внешнюю торговлю функции главной движущей силы экономического роста;

- тотальная отраслевая консолидация, вероятность создания международных суперкорпораций путем слияния, поглощения или объединения крупнейших ТНК мира;

- появление ряда новых социально-экономических явлений: безфрабричное производство, интернационализация, миграция; создание «глобального человека-работника»;

- торможения темпов глобализационных процессов вследствие замедления темпов мирового экономического роста;

- международная специализация стран, появление международных производственных цепочек ТНК с новой системой международного разделения труда;

- перемещение вредных производств за пределы стран-метрополий;

- увеличение доли наукоемкой продукции и уменьшение доли товаров первичной обработки и сырья; структурное смещение мирового экспорта в сторону продукции высокотехнологичных отраслей; финансирование корпорациями коммерческих направлений научных исследований;

- глобализация товарных рынков и развитие коммуникационных 
технологий, позволяет корпорациям отказаться от традиционных поставщиков товаров и услуг, отношения с которыми были закреплены общей собственностью;

- создание надгосударственных и межгосударственных органов регулирования глобализационных процессов, в том числе для решения важных глобальных проблем;

- неподконтрольность корпоративного капитала традиционным институтам глобального менеджмента позволяет избежать корпорациями государственного и демократического контроля; ослабление суверенитета национального правительства из-за посягательств корпорациями на власть государства для достижения цели.

В контексте изменения укладов и способов производства возможными последствиями современного кризиса цивилизационного масштаба станет модификация системы международного разделения труда, смена стран-лидеров, изменение состава ведущих корпораций. Сформируется новая архитектура глобального рынка с новыми регуляторными органами. Новым лидерам мировой экономики придется вырабатывать новые правила экономического порядка и создавать новые глобальные экономические институты.

Преодоление кризиса потребует трансформации собственно парадигмы развития. Будет происходить изменение теоретического обоснования экономических процессов и поиск новых инструментов экономического анализа. Так же, как в течение понижающей волны третьего цикла (30-е гг. XXв.) произошло вытеснение классического либерализма кейнсианской идеологией, а в течение понижающей волны четвертого цикла (70-е гг. XX в.) - вытеснение кейнсианства неолиберально-монетаристской теорией.

Глобальная институциональная интегрированность страны приобретает различные институциональные формы в виде международных региональных торговых блоков, международных межправительственных организаций, международных неправительственных организаций, международных фринансовых и 
денежно-кредитных организаций, международных отраслевых организаций, сырьевых картелей, единой валюты.

Нахождение страной «своего места» в мировом хозяйстве на основе глобальной интеграции становится системным фрактором развития национальной экономики, однако не лишено институциональных ловушек. Долговая ловушка, то есть пользование новых займов для обслуживания внешнего долга, заставляет страну передавать экономические и политические рычаги к международным кредиторам и открывать экономику для черного использования транснациональным капиталом. Объективность процессов глобализации с одновременным пониманием ее преимуществ и недостатков создает основу для нахождения механизмов эффективной интеграции национальной экономики в глобальную. 


\title{
РАЗДЕЛ 2
}

\section{ИНСТИТУЦИОНАЛЬНЫЕ ТРАНСФОРМАЦИИ ЭКОНОМИЧЕСКИХ СИСТЕМ}

\begin{abstract}
2.1. Теоретические основы институциональных изменений в экономике
\end{abstract}

Процесс трансформационных превращений можно рассматривать как непрерывные нефрормальные изменения, закрепляющиеся В формальной институциональной системе общества в виде соответствующих правовых актов, норм поведения и институциях, призванных контролировать их соблюдение. Институциональные изменения означают изменения экономического устройства общества, его структуры и алгоритма функционирования под действием существенных фракторов, которые накапливаются в процессе эволюции общества.

Институциональными называются такие изменения, которые знаменуют возникновение новых правил с соответствующими механизмами их обеспечения, соблюдения и отмирания старых правил. Происходят также изменения структуры трансакций в рамках существующего перечня правил для их участников. Такой подход к определению институциональных изменений учитывает то, что действующие правила означают не только появление новых установок, но и механизмов, которые обеспечивают их соблюдение субъектами уже существующих установок. Очевидно, это касается, прежде всего, неформальных правил. Что касается фрормальных, то они требуют определенных уточнений относительно возможного разрыва между задекларированными законодательством правилами и механизмом обеспечения их соблюдения. Наибольшего объема наработок новых правил требует именно трансформационная экономика, в которой они создают институциональную среду перехода к рыночным связям. Масштабность и сложность институциональных изменений не только 
порождает разрыв между установленными правилами и механизмами обеспечения их соблюдения, но и может в целом стать тормозом трансформационных процессов.

Среди основных институциональных правил и норм формирования и развития смешанной экономики целесообразно выделить такие [17]:

- урегулированность и управляемость процессами;

- взаимодополнения и преемственность;

- синергетический эфффект;

- условия для конкуренции;

- информационное обеспечение;

- свободный перелив ресурсов и капитала;

- индикативность.

Урегулированность и управляемость процессами формирования и развития смешанной экономики характеризуется тем, что параллельно должны сосуществовать как государственные, так и частные субъекты хозяйствования. В связи с этим необходимо определить экономикоправовые механизмы их взаимодействия и взаимодополнения, способные создать равные для всех условия ффункционирования. При этом необходимо гибко использовать налоговый механизм, фринансовокредитные рычаги, ценовую политику.

Взаимодополнение рыночных и нерыночных институтов экономики заключается в том, что господство рыночного механизма не в полной мере обслуживает потребности экономики, поэтому необходимо максимально использовать и нерыночные фрормы хозяйствования. Невозможно сразу и окончательно перейти к прямо противоположной экономической системе. Кроме того, современные экономические системы имеют смешанный характер, в которых имеют место различные экономические уклады.

Синергетический эффрект современной экономики заключается в том, что отдельные еe составляющие создают собственный эффрект в «запуске» и функционировании рыночного механизма. Но поскольку рыночная форма хозяйствования является составляющей частью смешанной экономической системы, то в комплексе она дает эффект, 
который во много раз превышает простую сумму укладов, что является следствием взаимодействия всех ее структурных частей как отдельных элементов. Это объясняется тем, что рыночная экономика в комплексе, функционирует абсолютно иначе и эффрективнее, чем ее элементы, взятые отдельно, когда каждое звено работает в собственном режиме и направлении. Схематически указанный эфффект представлен на рис. 2.1.

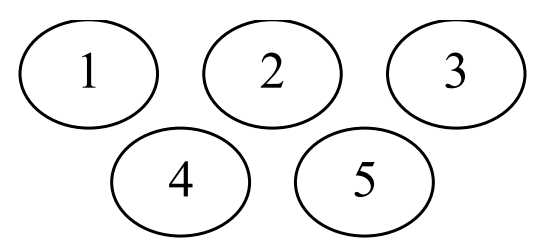

a) сумма элементов

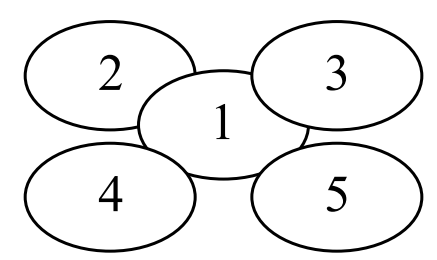

б) эффект интеграции элементов системы

Рис. 2.1. Синергетический эффект взаимодействия элементов в экономической системе [17].

Создание конкурентной среды, в отличие от распространенного в большинстве постсоциалистических стран законодательства антимонопольной направленности, не отрицает монополизма и даже его допускает, если он не является препятствием для развития экономики. Особенно это важно на нынешнем этапе, когда не продуманные мероприятия борьбы с монополизмом могут прямо или опосредствованно привести к усилению монопольного характера отдельных хозяйственных комплексов. И наоборот, процессы концентрации могут способствовать развитию конкуренции, предпринимательству и частной инициативе, установлению доступных цен, свободному доступу к рынку и т. п. Поэтому в основе этого принципа лежит экономическое равенство для всех участников, которые фрункционируют на рыночном пространстве 
экономики, содействие соблюдению «правил игры» всеми хозяйствующими субъектами.

Информационная обеспеченность направлена на то, чтобы рыночные структуры, предпринимательская, управленческая, регулирующая деятельность экономических агентов могла бы успешно осуществляться лишь в условиях единого информационного пространства. Инфрормационные подразделения рынка должны своевременно и оперативно обеспечивать информационные экономические службы на любом уровне управления, осуществляя тем самым свою инфраструктурную роль, создавая единую информационную среду. Такая среда должна иметь установленные параметры. Один из них достаточность информационного обеспечения или обеспеченность информационными ресурсами. Наличие достоверной и квалифицированной информации в достаточном объеме - непременное условие эффективного функционирования любой организации.

Принцип свободного переливания ресурсов является одним из основных условий функционирования рыночной экономики, поскольку он обеспечивает гибкость механизма самоналаживания системы, способствует структурным изменениям в экономике, осуществлению антикризисных защитных мероприятий и т. п.

Процесс аллокации ресурсов (финансовых, инвестиционных, интеллектуальных, инновационных, трудовых) реализуется с помощью соответствующих институций. Именно с их помощью можно обеспечить наиболее эфрфективное и оптимальное распределение ресурсов в соответствии с реальными потребностями экономической системы. Спекулятивные запросы фрирм, реагируя на накопившиеся структурные противоречия, находят соответствующую рыночную нишу, указывая направление переливания капитала.

Применение указанных институциональных правил и норм в формировании и развитии рыночного хозяйства создает благоприятную почву для развития системы экономических отношений и обеспечивает ее рыночную направленность. 
В рамках эволюционной теории характеристика институциональных изменений сводятся к таким утверждениям:

- постоянное взаимодействие институтов и организаций в условиях редкости экономических ресурсов, а значит, конкуренция приводит к институциональным изменениям;

- конкуренция принуждает предприятия и организации, которые стремятся выжить, инвестировать в знание и навыки;

- виды знаний и навыков, приобретенных индивидами и их организациями, фрормируют новые возможности, а последние постепенно изменяют институты;

- институционный каркас диктует виды навыков и знаний, которые позволяют получать максимальный выигрыш;

- восприятие возможностей возникает из ментальных моделей игроков;

- экономия от масштаба, эффекты дополнения и взаимовлияния с внешними структурами институциональной матрицы делают институциональные изменения чрезвычайно медленными и зависимыми от траектории развития [16].

Современная теория не отвечает на вопрос, как слаборазвитым экономикам превратиться в процветающие, но знание фундаментальных характеристик институтов, разработанных институционно-эволюционной теории, позволяет сделать определенные обобщения:

- основное условие устойчивого экономического развития - гибкая институциональная матрица, приспосабливающаяся к технологическим и демографическим изменениям, а также к взломам в системе. Существенной характеристикой является создание стабильного конституционного устройства общества, дополняемого неформальными нормами;

- формирование современной рыночной экономики объективно предусматривает создание новых институциональных образований (ассоциаций, концернов, консорциумов, корпораций), которые заполняют «вакуум» между государственными учреждениями и рынком [16]. 
Для того чтобы определить, что является институциональными изменениями, удобно воспользоваться «фрормулой» описания любого правила:

- описание ситуации, характеризующее условия дополнения к норме и определяющее, как следует действовать индивиду в соответствии с данным правилом;

- характеристика индивида, или адресата нормы, позволяющая определить, какие типы индивидов должны придерживаться правила;

- определение установленного действия, или содержания нормы, свидетельствующее, какие именно действия могут или не должны осуществлять адресаты правила в соответствующих ситуациях;

- описание санкции за невыполнение распоряжения, позволяющее адресату нормы определить, какие расходы он понесет, не выполнив установленное действие;

- характеристика гаранта нормы, то есть субъекта, применяющего санкции к нарушителю правила; такая характеристика позволяет адресату нормы точнее определить ожидаемые расходы от нарушения правила и принять более обоснованное решение [18].

Таким образом, изменение правила - это не изменение в поведении, которое может быть вызвано самыми разными, в частности случайными, причинами, а изменение содержания компонентов правила, позволяющие индивидам принимать решение о своих действиях.

Указанное не означает, что изменения в поведении индивидов, которые стремятся следовать правилу, включая случайные, неумышленные отклонения от порядка установленных действий, не могут привести к изменениям правила. Напротив, именно такие отклонения чаще всего и вызывают действительные изменения в правилах.

Дело в том, что отклонения от приказного порядка действий могут приносить их субъектам неожиданные выгоды - большие, чем те, на которые рассчитывал индивид, принимая решение следовать правилу. Причинно-следственная связь между состоявшимся отклонением в поведении и полученной выгодой может отобразиться в памяти индивида и 
при некотором числе ее повторов может трансформироваться в новое «индивидуальное правило», что отличаются от результатов в каком-то из компонентов: ситуации, содержании нормы и т.п. Новая практика через разные каналы передачи информации может распространиться на всех индивидов, которые оказываются адресатом «старого» правила, содержащегося в их памяти, в содержании которого, соответственно, состоится изменение. Это последнее и будет означать, что изменилось не только поведение, но и регулирующее его правило.

Если состоявшееся отклонение в поведении не принесло его субъекту осознанных им выгод (или привело к чистым убыткам); или потери от наказания превысили такие выгоды; или информация об отклонении не распространилась среди потенциальных адресатов нормы, то указанная последовательность событий не будет иметь места, и изменение в правиле не состоится.

Поскольку любой институт является совокупностью как минимум двух правил (формальных и неформальных), сказанное выше об изменениях в правилах поведения полностью относится (с соответствующими дополнениями) и к изменениям в институтах, то есть к институциональным изменениям. Рассмотренная цепочка событий, приводящих к изменению в правиле, может относиться не только к носителям, но и к гарантам института, то есть затрагивает и механизм принуждения к следованию норме.

Изменения могут быть дискретными и непрерывными. Под первыми понимают радикальные изменения в формальных правилах, которые обычно происходят в результате завоеваний или революций. Такие дискретные изменения имеют определенные общие черты с перерывчатыми эволюционными изменениями (характеризующиеся «точечным равновесием»). Однако из истории известно, что они редко бывают настолько революционными, как принято считать. Формальные правила меняются быстро, а неформальные ограничения быстро изменяться не могут, поскольку опираются на укоренившееся культурное наследие, устойчивые стереотипы мышления и способы действий. 
Лимитирующим фрактором институциональных изменений являются неформальные правила. Институциональные изменения носят преимущественно непрерывный (инкрементный) и кумулятивный характер. Инкрементные изменения означает, что участники процесса обмена пересматривают свои отношения с тем, чтобы получить определенный потенциальный выигрыш (по крайней мере, для одной из сторон обмена [10]. Кумулятивные институциональные изменения происходят от того, что, возникающее сдвиги во второстепенных правилах, приводят к постепенным изменениям в правилах высшего порядка, отображающих нарушение институционального равновесия. Например, развитие частной собственности (в данном случае правила низшего порядка) порождает новый характер экономических отношений, то есть рыночную экономическую систему (правила высшего порядка).

Непрерывное институциональное изменение характеризуется тем, что в деятельности экономических агентов трансформации происходят постепенно, путем адаптации действующих правил к новым условия малыми шагами и приростами.

Характер институциональных изменений часто зависит, а, возможно и определяется, траекторией предыдущего развития. Эта зависимость имеет две стороны. С одной стороны, на характер изменений существенно влияют действующие правила. Ведь формальные правила и, особенно, неформальные институты обладают значительной инертностью действия. С другой стороны, всегда существует значительная часть организаций и институций, которая не желает принимать новые правила, стараясь консервировать сложившиеся отношения. Это объясняется том, что многие политические и экономические организации, которые образовались в результате существования старой институциональной матрицы, стремятся сохранить действующую институциональную структуру [10].

Нужно выделить еще одну сторону влияния траектории предыдущей институциональной матрицы на институциональные изменения. Это касается цены внедрения новых правил и норм в проектирование новой институциональной матрицы. 
Такая институциональная матрица формальных правил, неформальных ограничений и характеристик принуждения, будет «настраивать» выгоды и расходы в сторону альтернатив выбора, совместимых с существующей институциональной структурой. Постепенность изменения обусловливает важность первичного институционального выбора, которая определяет траекторию институциональных изменений, а также экономическое развитие в долгосрочной перспективе. Очевидно, что малыми «отклонениями» и «приростами» изменяются не только локальные (формальные и неформальные), а и «глобальные» правила.

Выделяют также спонтанные и целенаправленные институциональные изменения. Спонтанными называются такие институциональные изменения, которые осуществляются, возникают и распространяются без предыдущего замысла и плана. Так, если случайное отклонение от нормы приносит выгоды ее нарушителю, не наносит никому ущерб (не встречает противодействия) и распространится среди членов группы, то будет иметь место спонтанное институциональное изменение. Целенаправленные институциональные изменения, наоборот, возникают и распространяются в большем или меньшем соответствии с определенным предыдущим планом, инициатором которого является государство; внутри экономических организаций автором такого плана выступает руководство. Формирование целенаправленных институциональных изменений называется институциональным проектированием [19].

По признаку происхождения институциональных изменений, кроме двух названных «чистых» типов, можно выделить еще и смешанный, когда именно новое правило появляется незапланированно, а его распространение осуществляется вполне сознательно целенаправленно.

Примером здесь может служить формирование новых законов в рамках системы общего права, когда новое правило - прецедент возникает в связи с решением суда на основе нового конкретного конфликтного случая, а «внедрение» этого правила в массовую практику обеспечивается механизмами судебной ветви государственной власти. 
Другой пример - спонтанное возникновение некоторой эффективной практики действий в бизнесе и еe распространение через разные институции бизнеса или с помощью системы торгово-промышленных палат.

\section{2. Развитие концепций институциональных изменений}

Базовой считается концепция, в которой изменения институтов, прежде всего, прав собственности, объясняются изменениями в относительных ценах экономических ресурсов. Возникновение или не возникновение исключительных прав рассматривалось этой теорией с позиции сопоставления расходов и выгод от исключения доступа индивидов к тому или иному имуществу, с одной стороны, и внутренних расходов совместного управления имуществом группой индивидов, с другой стороны. Фактором институциональных изменений в этой концепции выступает эффективность, понимаемая как прирост стоимости или богатства в обществе. Государство и политические процессы пассивные факторы, которые принимают любые изменения, обусловливающие рост чистой общественной выгоды. При этом подходе внимание акцентируется преимущественно на существовании спроса на институциональные изменения со стороны экономики, обусловленного недостаточной эфрфективностью использования ресурсов и не учитывающего потенциал их предложения, который зависит от способности и желания политической власти обеспечить новую институциональную среду.

Еще одной теоретической концепцией является подход (Дж. Найт), в соответствии с которым рациональный экономический агент не будет принимать участия в таком контрактном процессе, если его завершение принесет часть выгоды без каких-либо контрактов и расходов.

Спрос на институциональные изменения возникает со стороны частных агентов, которые заботятся исключительно о собственном благе. Лишь случайное общественное разрешение распределительного 
конфликта может привести к конечным результатам, которые оказываются также социально желаемыми.

Особенностью существующих концепций институциональных изменений является убеждение в том, что с изменением внешних условий формируются те институты, которые обеспечивают возможность экономического использования этих внешних изменений (в знаниях, технологиях, численности населения и т.п.). Считалось, что вновь созданные институты обеспечивают большую экономическую эффрективность, поэтому их появление является желаемым и безальтернативным. Второй момент, характерный для этих концепций, заключался в том, что институциональные изменения вроде бы автоматически следуют за изменениями условий экономической деятельности, без активных действий государства и других организованных социальных групп.

Другой базовой моделью институциональных изменений является модель Д. Норта. Она предусматривает такую логику институциональных изменений:

1) изменение в уровне знаний ведет к появлению новых технологий;

2) новые технологии меняют относительные уровни цен на ресурсы;

3) новые уровни цены создают стимулы у владельцев потенциально растущих в стоимости ресурсов к трансформации прав собственности на них;

4) новые уровни цен ведут также к появлению правил, позволяющих максимизировать ценность использования таких прав;

5) ненулевые трансакционные расходы на политическом рынке препятствуют тому, чтобы реализовались все полезные для создания стоимости потенциально возможные институциональные изменения [10].

Эта базовая схема институциональных изменений была впоследствии дополнена другими исследователями рядом важных моментов. К наиболее важным из таких дополнений следует отнести: возможность возникновения индуктируемых институциональных изменений, когда внешние фракторы меняются в одной сфере, а 
институциональные изменения появляются в другой; возможность возникновения в связи с осуществлением институциональных изменений эффректа безбилетника, связанную с тем, что институты во многом похожи с общественными благами; необходимость учета того обстоятельства, что выгоды от возможного институционального изменения, которые положительно влияют на создание дохода, будут получать одни экономические агенты, а расходы на их получение должны осуществлять другие, что может помешать их появлению.

В рамках приведенной схемы можно объяснить не только те институциональные изменения, которые улучшают условия создания стоимости, но и те, которые эти условия ухудшают.

Примером таких институциональных изменений выступают прежде всего административные барьеры. Для их анализа правила хозяйственной деятельности, являющиеся институтами, могут быть разделены на три группы:

а) способствующие созданию стоимости;

б) перераспределяющие создаваемую стоимость, но не увеличивающие затраты на ее создание более чем на дополнительные трансакционные расходы, которые связаны с процессом перераспределения стоимости;

в) препятствующие созданию стоимости путем запрещения наиболее эффрективных направлений использования ресурсов или путем возложения на субъектов хозяйственной деятельности непродуктивных расходов, связанных с их координирующей и ограничительной функциями.

Институциональные инновации. Основную роль в институционном развитии играют институциональные инновации, то есть те нововведения, которые осуществляются в формальных и неформальных правилах и при их взаимодействии.

Основные пять типов инноваций были определены И. Шумпетером в виде внедрения новой технологии производства известных продуктов, организации производства новых продуктов, открытия новых рынков продуктов и ресурсов, а также организационных нововведений. Главную 
роль в создании новых комбинаций фракторов производства играет предприниматель. Под воздействием перечисленных инноваций экономическая система выводится из состояния равновесия, а на предпринимателя возложена функция ее стабилизации.

Предприниматель выступает главным организатором новых институциональных соглашений, которые снижают неопределенность и создают базу для поиска компромисса в конфликте интересов.

Инновации могут носить характер общественного, частного и корпоративного блага, что учитывает архитектонику правил.

Прогнозируя возможности и динамику институциональных изменений, необходимо учитывать не только возможность фрормулировки новых или изменения старых правил, которые положительно отразится на производстве стоимости, но и следствия такой переформировки для групп и организаций, извлекающих выгоды от существования неэффективных правил.

Траектории институциональных изменений. Институциональные изменения нужно рассматривать как через призму количественного обхвата экономических агентов, так и качественных фракторов влияния (совершенства правил, часового интервала их внедрения и т. п.).

Ведь в одних случаях изменения институтов, например, законов о налогообложениях, которые снижают налоговый груз государства, происходит практически мгновенным увеличением числа налогоплательщиков; для других, таких как деловые традиции добросовестного выполнения контрактов, привлечение новых сторонников из числа бизнесменов может происходить на протяжении длительного времени и т. п.

6) Разные институциональные изменения проходят разные траектории своего развития. Для описания этих траекторий в количественном аспекте, отображающем динамику распространения институционального изменения в экономике, В. Тамбовцев предлагает употреблять термин «режим функционирования института» [20].

Выделяются следующие основные режимы функционирования 
институтов:

- бездеятельность; при функционировании нормы в этом режиме индивиды знают о правиле; им известно, как нужно поступать в определенной ситуации, однако они действуют иначе; в данном режиме могут существовать преимущественно фрормальные институты;

- спорадическое действие; данный режим отвечает такой практике, когда при возникновении определенной ситуации данное правило может применяться, а может и не применяться; в последнем случае индивиды ведут себя, исходя из других правил;

- систематическое действие; правило, существующие в режиме систематического действия, оказываются применимы всегда (или почти всегда), когда в деятельности индивидов возникают ситуации, которые совпадают с условиями использования соответствующей нормы.

Под качественными изменениями в институциональной траектории понимают последовательность изменений, которые испытывает некоторый данный (базовый) институт.

Примером такой траектории может служить последовательное изменение определенного закона или традиции, осуществляемого на протяжении нескольких лет или и десятилетий путем внесения в него поправок.

Каждая такая поправка может отображать накапливающийся опыт применения закона, уточняя то или иное из его положений, добиваясь более полного достижения цели, которую преследовал законодатель, принимая соответствующие правовые нормы.

Для траекторий изменений институтов различают два, существенно различных их типа:

1) траектории, которые формируются инкрементными (постепенными) изменениями;

2) траектории как определенные «разрывы», содержащие скачки или «институциональные шоки», когда один институт перестает действовать, а его функции в экономике начинает выполнять другой институт (или целая их группа). 
В соответствии с классификацией институциональных изменений траектории второго типа можно охарактеризовать как включающие дискретные изменения. Институциональные изменения траектории, возникающие в процессе эволюции, имеют не произвольный характер, а подчиняются определенной закономерности, которая получила название «зависимость от траектории предыдущего развития».

В целом, современные концепции институциональных изменений определяют возможности государства реально изменять фрормальные институты в двух направлениях: 1) распределение сил в обществе и на политическом рынке, то есть распределение выгод и потерь от ожидаемых изменений, которые могут понести определенные группы специальных интересов; 2) величина расходов на осуществление необходимого коллективного действия, которая может стать запрещённое высокой, несмотря на значительные потенциальные выгоды.

В. Тамбовцев развивает альтернативную концепцию институционный рынок как механизм институциональных изменений. Внедрение институциональных инноваций осуществляется через так называемый институционный рынок. Как отмечает С. Пейович, «рынок институтов - это процесс, позволяющий индивидам выбирать правила игры в их содружестве. С помощью своих добровольных взаимодействий индивиды оценивают преобладающие правила, определяют и проверяют пригодность новых. Важнейшей фрункцией этого конкурентного рынка выступает поощрение институциональных инноваций и форм адаптивного поведения» [20]. На рынке институтов происходит их конкуренция (метаконкуренция, по Ф. Хайеку). Под «конкуренцией между правилами» имеют в виду конкуренцию между индивидами и группами, которая осуществляется с помощью правил и институтов. Победа того или иного института означает, что он приобрел массовое распространение в экономическом поведении хозяйствующих субъектов, а проигрыш показывает, что данное правило перестает применяться вообще или ему следуют изредка в определенных ситуациях. Следование индивида тому или иному правилу обусловливается не только текущими экономическими 
выгодами, но и социокультурными условиями.

Обобщая концепцию институциональных изменений, можно отметить три важных момента:

- институциональные изменения можно рассматривать на основе общего понятия жизненного цикла, то есть следует выделять фразы зарождения изменения (институциональную инновацию), функционирования института и его отмирания, что может быть одновременно и фазой возникновения нового института;

- внутри фразы институционального нововведения выделяется три основных источника инноваций - заимствование, неумышленное изобретение, целенаправленное (умышленное) изобретение или институциональное проектирование;

- на этапе распространения нового института важно различать два принципиальных механизма: государственное принуждение к использованию, допускающее выбор нового института через механизм политического рынка, и добровольное принятие хозяйствующими субъектами нового правила через механизм рынка институтов.

\section{3. Механизмы институциональных изменений}

Причины изменений, по мнению институционалистов, лежат в плоскости склонности человека к «необдуманной», непрагматической творческой деятельности и экспериментированию («праздное любопытство»), что, по мнению Т. Веблена, является главным источником социальных, научных и технических изменений. «Праздное любопытство» создает новые стереотипы мышления, поведения и соответственно новые институты [20].

Другой источник изменений - конфликты между самими институтами, особенно теми, которые сложились в разные исторические и культурные эпохи.

Очевидно, механизм институциональных изменений запускается путем объединения внешних изменений и внутреннего накопления знаний. 
Изменения в фрормальных правилах могут стать результатом юридических и законодательных изменений, изменений в регулирующих правилах, которые вводятся властными структурами, а также изменений в конституции, что определяет метаправила, по которым строится вся система правил.

Изменения в неформальных ограничениях осуществляются постепенно и нередко формируют у индивидов альтернативные модели поведения, связанные с новым восприятием выгод и расходов.

Институциональные изменения зависят от траектории предыдущего развития. Суть этой зависимости заключается в том, что в каждый данный момент времени в экономике могут состояться не любые (произвольные) институциональные изменения, а лишь те, которые оказываются осуществимыми в тех условиях, которые сложились раньше и которые, в свою очередь, возникли как следствие предыдущих аналогичных ситуаций.

Понятие зависимости от траектории предыдущего развития (ЗТПР) было сперва введено для характеристики особенностей изменений в производственных технологиях. Оно означало ситуации, в которых продолжение применения не самых эффрективных технологий обусловливалось влиянием случайного выбора на начальном этапе их использования и закреплялось в результате эффекта растущей отдачи, что в целом порождало феномен блокировки альтернативных путей технологического развития. Практика последующего использования данного понятия показала, что с его помощью начали анализировать разные феномены не только технологической, но и институциональной природы, с разных теоретических позиций.

Во-первых, эта трактовка ЗТПР институциональных изменений отвечает идеям Девида и Артура. Согласно последним, ситуация в технологическом развитии характеризуется ЗТПР, если:

- выбор наблюдаемой в действительности массовой технологии не был предусмотрен;

- этот выбор практически невозможно изменить из-за величины расходов, которые нужно осуществить скоординировано и одновременно 
(или на протяжении короткого времени);

- массово распространенная технология с большой вероятностью неэффективная.

Возникновение таких ситуаций, в свою очередь, является результатом функционирования двух механизмов: а) растущей отдачи от масштаба и б) влияния небольших случайных событий.

Растущая отдача является следствием взаимосвязанной технологии и навыков труда, которые совершенствуются с ней, как часть человеческого капитала, возникающего в результате процесса учебы в ходе применения технологии, а также сетевых внешних эффректов и неперемещаемости инвестиций.

Механизм случайных событий, то есть таких событий, которые не могли заранее быть предусмотрены, в связи с ограниченным знаниям постороннего наблюдателя, «ответственного» за то, какая именно, из доступных технологий, будет фрактически выбрана, победившая в конкурентной борьбе с функционально похожими с ней технологиями. Но такой выбор обычно не связан с большей эффективностью.

Таким образом, в данном понимании ЗТПР причины того, что в данный момент времени в технологической структуре экономики некоторые из известных технических нововведений в принципе эфффективнее, чем реально используемые, однако не применяемые на практике, имеют двоякий характер.

Прежде всего, это ограниченная рациональность экономических агентов, которые выбрали и начали в массовом порядке осваивать не лучшую технологию, кроме того, чисто экономические фракторы, обусловливающие нецелесообразность изменения технологий из-за угрозы возникновения значительных расходов.

Во-вторых, понятие ЗТПР в имеющейся литературе по институциональным изменениям активно используется в рамках шумпетеровской и неошумпетеровской традиции анализа технологических изменений.

В соответствии с ней технологические изменения включают 
творческое разрушение и рекомбинацию существующих знаний в новых формах. Тем самым технологические инновации осуществляются в рамках определенных кластеров, что является ограниченным кругом вариантов технологий, которые могут быть сформированы по первичному знанию с помощью названных когнитивных механизмов рекомбинации. Развитие этих положений привело к появлению понятия технологической траектории как эволюционной последовательности технологий, которые обновляются, но не выходят за пределы общего кластера, определенным базовым набором знаний (открытий или изобретений). Изменение технологической траектории возможно лишь с появлением нового «ядра» кластера, то есть принципиально отличных изобретений или открытий новых законов природы.

В этом понимании ЗТПР обусловлена чисто когнитивными причинами: базовая инновация развивается и совершенствуется путем небольших улучшений до тех пор, пока не возникнет новая базовая инновация. Экономические факторы, способные влиять на принятие или отказы от инноваций, имеют в рамках данной концепции «фроновый» характер: это общие требования обеспечения максимальной (или приемлемой) экономической эффективности для любого инвестиционного проекта.

Обе охарактеризованные трактовки ЗТПР в сфере технологических изменений, будучи примененными к сфере изменений институциональных, приводят к, существенно, разным оценкам возможности осуществления значительных или резких изменений институциональной системы экономик.

В соответствии с первой из таких трактовок нет никаких ограничений на содержание идеи нового института (или системы институтов), кроме ограничений творческих способностей индивидов, которые формируют институциональную среду в своих интересах. Идея институционального изменения может при этом также заимствоваться или целеустремленно создаваться, то есть проектироваться. Однако в массовую практику войдет лишь то институциональное изменение, выгоды от которого будут выше 
расходов на переход к новому правилу. Очевидно, такой переход может быть обеспечен также и путем искусственного снижения эффрективности использования старого правила, например, за счет резкого роста величины санкций, которые налагаются государством на индивидов, которые продолжают ему следовать. При этом теряется стоимость ранее созданного человеческого капитала, специфического по отношению к старому правилу, однако ожидаемая суммарная выгода от использования нового правила с учетом дисконтирования полностью компенсирует такие потери.

В соответствии со второй трактовкой ЗТПР в рамках сложившейся институциональной среды не могут возникнуть идеи институциональных инноваций, которые не являются рекомбинацией компонентов правил, образующих эту среду. Целенаправленное проектирование нового правила оказывается при таком подходе принципиально ограниченным рамками разнообразия, что формируется полным набором всех возможных сочетаний упомянутых компонентов. Заимствованная идея, не заключающаяся в эти рамки, отбрасывается не как следствие неэффективности, а в результате несоответствия уже существующим правилам.

Данная концепция отрицает возможность конвергенции экономических систем, которые сначала базировались на несовпадающих институциональных структурах.

Имеющийся опыт как технологических, так и институциональных изменений убедительно свидетельствует, что идеи нововведений, которые проходят через фильтр отбора по критерию эффективности, будут определять, какие из них (с учетом эффректа растущей отдачи и случайности первичного выбора) приобретут массовое распространение.

Отбор вариантов институциональных изменений по критерию эфффективности, которая оценивается ограниченно рациональными экономическими агентами, может рассматриваться как разновидность рыночного отбора.

Эффрект блокировки. Понятие эффректа блокировки было 
использовано Д. Нортом для объяснения ситуаций, когда институциональное изменение, встречающееся на практике и способное существенно улучшить условия для производства стоимости, несмотря на это, не реализуется на практике, прежде всего из-за действия государства, с помощью принятия законов, издания указов и т. п.

Эффрект блокировки заключается в создании препятствий изменению правил организациями, которые получают распределительные выгоды от использования действующих правил.

Способы блокировки потенциально эффективных институциональных изменений, которые используются на практике, достаточно многообразны: от идеологических обоснований недопустимости этих изменений, с ссылками на традиции, национальный менталитет и т.п., к прямому подкупу законодателей или руководителей исполнительной власти, в чьей компетенции находится осуществление соответствующего институционального изменения.

Возможности блокировки потенциально эффрективных институциональных изменений особенно значительны тогда, когда бенефициарами действующих правил оказываются не частные организации, а государство. Например, нескольких лет подряд в Украине не принимается закон об акционерных обществах.

Вместе с тем, поскольку неэффрективные правила, установленные государством для экономических агентов, могут привести к ослаблению государства, последнее рано или поздно сталкивается с необходимостью проведения экономических реформ для замены удобных для власти, но неэффективных (для создания стоимости) правил другими, способствующими экономическому развитию.

Новая институциональная экономическая теория рассматривает институциональные изменения через призму рыночных трансакций, выделив отдельно институционный рынок. На этом рынке осуществляются имеющиеся институциональные операции, непосредственно направленные на смену существующего институционального уклада, а также неявные, то есть действия по выбору определенного правила, в 
соответствии с которым может быть осуществлен товарный обмен. Поскольку в результате таких действий изменяется частота использования определенных правил, меняется и режим функционирования этих правил, а следовательно, происходит изменение существующей институциональной структуры.

К явной институциональной операции можно отнести установление новых правил государственной регистрации фрирмы или ее товарного знака, нового порядка лицензирования в каком-то регионе, занятий определенным видом деятельности и т.п. Для явных институциональных операций существенно то, что они определяют новое правило, не указывая и не предопределяя, какие именно будущие трансакции в соответствии с ним будут осуществляться, фриксируя только тип таких трансакций. Именно такое задание правила для определенного типа трансакций является целью заключения явного институционального соглашения.

Суть неявных институциональных операций состоит в том, что вместе с конкретной товарной операцией неминуемо осуществляется и выбор определенной институциональной формы, в которой происходит данная товарная операция. Никакой обмен невозможен вне определенной формы, порядка или алгоритма действий. При этом выбирается и форма, которая представляется экономическому агенту или агентам наиболее эфффективной среди известных и (или) доступных им фрорм, в которой осуществляется «базовая» товарная трансакция. К неявным институционным операциям можно отнести: заключение соглашения о снабжении товаров с предоплатой или в бартерной форме; устное, а не письменное определение нового порядка взаимодействия работников в организации и т. п.

Поскольку сравнительная эфффективность институтов зависит от конкретных условий выполнения действия, распространенность того или иного института в каждый данный момент или период времени оказывается опосредствованной функционированием институционального рынка. Эта опосредованность имеет место даже в том случае, когда данный институт является объектом ранее осуществленной операции на 
политическом рынке, то есть индивиды принуждаются к следованию соответствующему правилу силой государства (или внутриорганизационным контрактом).

Для того, чтобы осуществилась неявная институциональная операция, необходимо, чтобы продавец (покупатель) нашел партнера, согласного осуществить товарную операцию именно по соответствующему правилу. Однако партнер - совсем не единственный участник операции по приобретению права на использование правила: если последнее не является самоосуществляющимся, для его выполнения необходимо также усилие гаранта правила, то есть определенные услуги по принуждению потенциального нарушителя к выполнению заключенного соглашения. Например, самостоятельная договоренность между участниками дорожнотранспортного происшествия.

Таким образом, экономические агенты, действующие на институционном рынке и заключающие неявные институциональные соглашения, подобны потребителям на рынке монополистической конкуренции, которые выбирают товары, похожие по своим «физическим» свойствам, но различаются по товарным знакам, которые предоставляют им большую или более малую ценность.

Институциональное равновесие институциональных изменений. Согласно определению Д. Норта, институциональное равновесие - это такая ситуация, в которой при данном соотношении сил игроков и данном наборе контрактных отношений, которые осуществляют экономический обмен, ни один из игроков не считает для себя выгодным тратить ресурсы на реструктуризацию соглашений.

Иначе говоря, институциональное равновесие является отправной точкой всякого институционального изменения, то есть того начального состояния, по отношению к которому рассматриваются институциональные изменения.

В терминах модели рынка институтов общее определение институционального равновесия означает ситуацию, в которой величина спроса на услуги гарантов определенного правила равна величине их 
предложения. В этих условиях расширение соответствующих мощностей действующих гарантов или выход на рынок нового, «дополнительного» гаранта приведет не к увеличению числа субъектов, которые используют данное правило, а к снижению цены на услуги гарантов.

Понятие институционального равновесия может трактоваться и как локальное, относящееся определенной ограниченной группе индивидов и правил, и как глобальное, относящееся ко всей экономике.

Трансформация централизованных экономик в рыночные в конце 1980-х - начале 1990-х гг. в ряде стран дала множество примеров институциональных изменений разных масштабов и уровней, начиная с изменений конституционных правил и заканчивая многочисленными изменениями на уровне частных институциональных соглашений. Более того, самые экономические рефрормы исследователи рассматривают как своеобразные институциональные изменения дискретного характера.

Теоретическое обсуждение проблем переходных экономик сначала сводилось к известной «триаде» - либерализация торговли (ценообразование), фринансовая (макроэкономическая) стабилизация и приватизация государственной собственности на предприятия. При этом в центре обсуждения были вопросы о том, в каком порядке целесообразно осуществлять реформы, проводить их постепенно (градуалистские) или параллельно, единственным пакетом ит.п. Достаточно интенсивно (по крайней мере в среде отечественных экономистов) обсуждали понятие переходной экономики, критерии переходности экономических систем и др. Вопросы институциональной трансформации, и, прежде всего, создания надежно защищенных прав собственности и контрактных прав, а также других институтов функционирования рынка, то есть базовых условий обеспечения эфффективного использования ресурсов, находились вне сфреры внимания как подавляющего большинства экономистов, так и политиков.

Ситуация начала меняться в середине 1990-х гг., когда практика показала, что реализация упомянутой триады реформ совсем не обязательно приводит к повышению эффрективности функционирования 
экономики, к надежному укоренению рыночных фрорм поведения предприятий. Свобода ведения хозяйства, которая не ограничивается рамками надежно защищенных правил, часто сводилась не к производительному, а к рентоориентированному, перераспределяющему поведению, которое не обеспечивало рост стоимости (общественного богатства). Незащищенность государством прав собственности и контрактных прав открывали широкие возможности для осуществления теневых операций, вели к росту неформального сектора экономики, что, в свою очередь, сокращало налоговую базу государства. Несистемное принятие законов и их постоянное изменение фактически повышали уровень неопределенности при принятии хозяйственных решений, существенно увеличивая трансакционные расходы. Все эти обстоятельства значительно повысили интерес ученых к изучению переходных экономик под углом зрения институциональных изменений.

Так, с институциональных позиций были сформулированы варианты критерия переходности экономической системы. Во-первых, это наличие в ней институционального рынка, на котором предлагаются правила, которые относятся к разным типам обменов, а во-вторых, значительный удельный вес неформальных экономических отношений.

В тот же период были сфрормулированы подходы, предусматривающие разработку таких правил, - элементов институциональной среды и институциональных соглашений, - которые будут вынуждать экономических агентов принимать решения, повышающие, по мнению субъекта реформы, эфрфективность использования ресурсов. Такие частичные вмешательства имеют цель компенсировать провалы (или несовершенство) рынка. Согласно теории Г. Коуза, реформаторы должны концентрировать усилия на решении трех конкретных задач: 1) спецификации прав собственности; 2) снижении трансакционных расходов; 3) развитии конкуренции, учитывая, что на этой базе частная активность хозяйствующих субъектов приведет без дополнительных усилий к желаемому росту производства стоимости.

Применение новой институциональной экономической теории к 
проблемам переходных экономик не ограничивается приведенной оценкой достаточно общего характера. Практически все сфреры и секторы переходных экономик были и являются предметом достаточно интенсивные исследования, в частности прикладного характера, нацеленные на изучение особенностей осуществления в них институциональных изменений.

\section{4. Институциональное проектирование в экономике}

Трансформация экономики в период больших институциональных изменений неразрывно связана с массовым созданием новых институтов. Для их создания необходимо институциональное проектирование. Под институционным проектированием (ИП) понимается деятельность, направленная на разработку моделей экономических институтов, сознательно и целеустремленно внедряемых в массовое хозяйственное поведение. Основная проблема заключается в разработке таких правил и принципов деятельности, соблюдение которых способствовало бы эффрективному решению тех проблем, для преодоления которых они создавались.

В соответствии с подходом, предложенным Тамбовцевым, выделяется пять принципов ИП: 1) этапная полнота; 2) компонентная полнота; 3) достаточное разнообразие стимулов; 4) максимальная защищенность от оппортунистического поведения; 5) соучастие. Первые два принципа являются общими для любой проектировочной деятельности, а последние три более специфические для институционального проектирования.

Принцип этапной полноты проекта. Поскольку разработка проекта (нормативной модели) предполагаемой коллективной деятельности является разновидностью процесса принятия и реализации управленческого решения, последовательность этапов такой разработки совпадает с последовательностью шагов при принятии решений. Рассмотрим эти этапы.

Определение цели проекта. Предлагает характеристику будущего 
желаемого состояния экономических процессов, которые должны наступить в результате функционирования создаваемого института. Цель проекта - логическое отрицание какой-либо осознаваемой субъектом проблемы - нежелательного, с его точки зрения, состояния экономических отношений, процессов, явлений.

Разработка вариантов достижения цели. Это формирование структур индивидуальной и групповой деятельности экономических агентов, в результате которой должно осуществиться желаемое изменение в экономических процессах. Во-первых, каждый вариант разрабатываемого проекта должен отвечать второму принципу - принципу компонентной полноты проекта, то есть включать все те составляющая деятельности, без которых она не может осуществиться. Во-вторых, поскольку заранее неясно, какой именно экономический институт позволит наилучшим образом осуществить желаемое изменение, варианты, которые разрабатываются, должны принадлежать всем допустимым типам институтов. Таким образом, на данном этапе необходима развернутая, многоаспектная классификация экономических институтов. В-третьих, наличие множества вариантов экономических институтов как средств достижения той или иной цели ставит вопрос о критериях выбора одного из них для последующего осуществления. Каждый из вариантов, который разрабатывается, должен сопровождаться прогнозной оценкой трансакционных расходов, включая и связанные расходы, возникающие у тех экономических агентов, на деятельность которых будет влиять реализуемая институциональная инновация.

Формирование критериев отбора вариантов. Этот этап сокращает число альтернатив, которые разрабатываются. Для заданий ИП очевидными являются как минимум два критерия отбора:

1) обеспечение достижения цели проектирования;

2) обеспечение минимальных трансакционных расходов осуществления альтернативы.

Кроме того, варианты необходимо анализировать также с точки зрения специфических критериев: 
а) наличие необходимых для осуществления проекта ресурсов, исходя из возможностей субъекта;

б) период времени реализации проекта;

в) другие специфические критерии.

Выбор наилучшего варианта институционального проекта. Поскольку выбор осуществляется по нескольким критериям, он имеет характер принятия сложного решения. В этой связи значимой становится процедура принятия решения, то есть порядок дополнения критериев к множеству разработанных вариантов. Рациональны две структурных схемы такой процедуры. В рамках первой оба критерия (а) и (б) используются как своеобразные фильтры, позволяющие отбрасывать неприемлемые варианты. Среди оставшихся вариантов отбираются те, которые обеспечивают полное достижение поставленной цели (1), а затем тот, который характеризуется минимальными трансакционными расходами (2). В рамках второй схемы варианты, удовлетворяющие критерии (а) и (б), оцениваются таким образом: выделяются те, которые имеют приемлемые трансакционные расходы (2), а из них выбирается вариант, максимальный уровень, позволяющий достичь цели субъекта (1). Первая схема больше подходит для случаев ИП, в которых цель задана «точечно», то есть в виде состояния, относительно которого можно сказать, достигнуто оно или не достигнуто. Вторая схема - для случаев «интервального» достижения цели, когда можно измерить соответствующий уровень ее достижения.

Детализация и оформление выбранного варианта проекта. Этот этап ИП выполняет функцию доработки общей схемы института до уровня наполнения ее конкретными субъектами: исполнителями, физическим и юридическим лицами. Подобная детальная конкретизация для каждого из данных вариантов проекта нерациональна, выбор на предыдущем этапе может осуществляться на уровне схем институциональных вариантов и приблизительных оценок. Данная последовательность этапов ИП является упрощенной логической схемой, что позволяет выделить существенные моменты, отвлекаясь от сложностей, разнообразия, конкретных особенностей реального процесса ИП. 
Принцип ИП компонентной полноты проекта. Любая производительная деятельность, то есть действия, направленные на получение реального результата, возможна при наличии следующих компонентов:

- объекта действия, превращения;

- средств действия на объект;

- субъекта деятельности;

- знаний субъекта о том, как с помощью средств изменять объект;

- целей, мотивов и стимулов действий субъекта;

- условий, фрорм и способов соединения перечисленных выше компонентов, которые позволяют осуществить необходимые действия.

Названные компоненты образуют определенную минимальную систему, имеющую свойство взаимодополняемой: при отсутствии любой из составляющих деятельность не осуществится и результат не будет получен. Тем самым принцип ИП компонентной полноты указывает на те элементы экономического института, которые формируются и которые должны стать предметом вариантной проектной проработки относительно конкретных целей ИП. Полный институционный проект должен включать два подраздела: компоненты института и компоненты, которые обеспечивают его создание, увязку и взаимодействие с другими существующими институтами.

Принцип ИП достаточного разнообразия стимулов. Данный принцип ИП имеет более частный характер и другую область применения, чем рассмотренные выше. Суть его заключается в следующем. Множество мотивов и стимулов действий отличается очень широким разнообразием. При этом одно и то же действие может быть вызвано у разных субъектов разными причинами. Задание проектировщика - создать такую конструкцию, в рамках которой действие, предусмотренное проектом, осуществлялось бы с максимальной достоверностью.

Это можно, во-первых, осуществить путем оперативной наладки функциональной позиции, предусмотренной проектом, на профриль преимуществ того субъекта, который в данный момент эту позицию 
занимает. Потому в рамках сорормированного института для такой настройки целесообразно предусмотреть специальную службу. Для этого необходимо анализировать профиль преимуществ конкретного субъекта, вступающего в ту или иную функциональную позицию, подбирать для него действенные стимулы выполнения его роли, включать эти стимулы в ситуацию принятия решений, корректировать их и т.д. Суть данного подхода - в максимальной индивидуализации условий действий субъекта за счет осложнения структуры всего проектируемого института.

Во-вторых, в процессе ИП с каждой функциональной позицией можно связать определенное количество стимулов для соответствующей деятельности, передав выбор одного из них тому субъекту, который в какой-либо момент времени будет занимать эту позицию. При таком подходе нет необходимости с помощью специальной службы настраивать стимулы конкретного субъекта - настройку выполняет сам субъект, выбирая из предложенного набора поощрений то, которое для него больше всего подходит.

Принцип ИП достаточного разнообразия стимулов предполагает второй способ стимулирования, упрощает структуру экономического института, снижает трансакционные расходы, делает данный вариант более приемлемым.

Принцип ИП максимальной защищенности от оппортунистического поведения. Запроектированный экономический институт призван, в первую очередь, удовлетворить потребности заказчика разработки. Процесс реализации его интересов неминуемо касается интересов других субъектов, результаты действий которых через сеть обменов обеспечивают желаемые заказчиком преимущества и выгоды. В рамках института его участник получает свою выгоду, сделав те действия, получив тот результат, который предусматривался проектировщиком и предопределял выгоду заказчика. Если при этом фрормальные условия получения поощрения участником выполнены, а действие, в сущности, не выполнено, то участник взаимодействия, естественно, стремится получить поощрение. 
При этом он не действует в соответствии с занятой им функциональной позицией, а использует свое пребывание в ней для получения дополнительных поощрений вне данного института. Подобное оппортунистическое поведение, отклоняющееся от предусматриваемого в рамках проекта, возможно тогда, когда в рамках института осуществляется опосредствованный обмен, то есть результаты действий субъекта предварительно приобретают ту или иную знаковую форму, после чего ему выдается определенное вознаграждение.

Наиболее типичный пример такого поведения - феномен «труд на показатель», широко распространенный в иерархических структурах управления. Чтобы контролировать работу исполнителей, центр разрабатывает показатели и сложные системы оценки их деятельности, однако исполнители, формально выполнив показатели и получив соответствующее вознаграждение, используют сохраненные ресурсы на другие, не предусмотренные центром, цели.

Другой источник оппортунизма - неопределенность действий, выступающая как объект обмена для участника института, средство получения обусловленных в рамках института выгод. Разное понимание характера и результата действия у того, кто его осуществляет, и у получателя результата вызывает (в случае симметричности, добровольности обмена) конфликт, требующий обращение к третьей стороне (суду, арбитру и т. п.). Это или осложняет структуру института (если такой субъект «встроен» в него), и замедляет функционирование института. Если же данный обмен носит асимметричный характер, и сторона, которая оценит его как невыгодный, откажется от участия в структуре института.

Еще одна причина оппортунистического поведения - противоречие правил тех институтов, одновременным участником которых является любой экономический агент: соблюдение правил одного из них влечет за собой нарушение правил другого. Такое поведение становится массовым, если противоречивыми оказываются законы, регулирующие экономическую деятельность. 
В основе всех этих случаев лежит недостаточный учет интересов и потребностей реальных экономических агентов, включенных в структуру проектируемых институтов, что должен принять во внимание проектировщик. Таким образом, данный принцип продолжает и развивает принципы компонентной полноты проекта и достаточного разнообразия стимулов.

Принципы соучастия. Сложности и проблемы ИП могут возникнуть в том случае, если этот процесс, включая встраивание создаваемого института в институциональную среду экономики, осуществляется как процесс обращения разработанных схем действий тем субъектам, которые их будут выполнять по проекту. Принцип соучастия допускает противоположный подход: наибольшие шансы на «выживание» имеет тот институт, который формируется при самом широком участии всех заинтересованных субъектов на всех этапах его проектирования. По мере общности этот принцип примыкает к первым два, а также играет роль конструктивного способа реализации третьего и четвертого принципов в процессе ИП.

В целом этот методологический подход - возможный вариант ИП, то есть сознательного формирования экономических (преимущественно формальных) институтов, который может конкретизироваться относительно отдельного типа институтов.

На современном этапе изменение экономических институтов стало в основном результатом реформ, то есть целенаправленных мероприятий разного масштаба, которые проводятся по определенному плану. Реформы генерируют институциональные инновации, часть которых реализуется в их задуманном варианте, другая часть воплощается в отличном от первичного виде, а третья быстро погибает. Поэтому теория переходной экономики должна стать важной частью институциональной экономики. Большое значение в этой теории имеет переходная рента. Ограничение свободного движения ресурсов или уровня цен порождает дополнительный (по сравнению с конкурентным равновесием) рентный доход. 
Переходная рента - доход, возникающий в частном секторе в результате движения к равновесию, которое некоторые экономические агенты получают благодаря занятым ими позициям. В переходном состоянии, требующем в зависимости от условий значительного времени, может состояться перераспределение ренты, то есть частные фрирмы получают рентные доходы, от которых отказалось или не смогло получить государство (например, в условиях либерализации). Хотя эти доходы со временем исчерпываются, на начальном этапе они приводят к обогащению небольшой группы лиц при падении благосостояния основной массы населения.

Другим следствием является то, что в переходном процессе часть ренты просто рассеивается, поскольку ресурсы тратятся на осуществление самого переходного процесса. В частности, потери возникают из-за нескоординированности действий экономических агентов и являются частью расходов институциональной трансформации. Возможно, они обусловливают так называемый трансформационный спад производства. Дискоординация и размывание ренты в условиях спада производства и роста диффреренциации доходов населения создают предпосылки попадания экономической системы в разные институциональные ловушки.

Задание ИП состоит в том, чтобы разработать такую систему политических институтов, которая могла бы минимизировать прибыльность деятельности, направленной на размывание ренты (Д. Норт). Возможно, на начальном этапе реформ целесообразно исключение переходной ренты в интересах государства с целью предотвращения резкой диффреренциации доходов, криминализации общества.

Эфрфективным ИП будет в том случае, если оно обеспечит, при прочих равных условиях, минимальные отклонения от полученных результатов. Однако заказчик институционального проекта не всегда заинтересован в формировании институтов, которые обеспечивают такую экономию. В целом результативность ИП и эффективность институтов, которые возникают в результате его осуществления, - разные вещи, что является следствием асимметричности распределительных эфффектов, 
которые порождаются правилами, и неполнотой данных правил.

Таким образом, значимость анализа институциональных изменений как позитивного, так и особенно нормативного, в современном мире чрезвычайно большая: практически непрерывно институциональные изменения происходят во всех переходных экономиках, в рамках ЕС, в странах, которые развиваются. Одни из них ощутимо положительно влияют на последующее развитие экономики, другие, напротив, способствуют стагнации, третьи, несмотря на замысел авторов, вообще не влияют на экономическое поведение.

Массовые институциональные изменения происходят и на уровне отдельных экономических организаций - фирм, корпораций и т.п. Здесь также есть примеры удачных и неудачных изменений. Потому их изучение должно быть объектом постоянных научных исследований и хозяйственной практики.

\section{5. Институционализация прав собственности}

Среди важнейших базовых элементов институциональной системы экономики главное место занимают отношения собственности. Развитие ее форм обеспечивает институциональную основу экономики частной собственности, так называемую новую конституцию порядка. Конституция порядка - это конституционные правила, которые структурируют отношения людей в обществе.

Реализация конституционных фрормальных и неформальных правил, на наш взгляд, осуществляется на основе разграничения прав собственности как между уровнями конституционной иерархии (органами власти), так и между субъектами ведения хозяйства. Права собственности являются основой конституционных прав в экономической сфере, то есть они определяют экономические правила, являются их порождением и результатом развития. Обнаружить взаимную зависимость между правами собственности и экономическими правилами очень важно по двум причинам. Во-первых, необходимо установить, что является причиной, а 
что следствием, производной названного взаимодействия. Во-вторых, важно обнаружить механизм последней, потому что именно в нем есть ключ к раскрытию институционального содержания взаимодействия экономических агентов.

Экономическая теория, как и другие общественные науки, имеет достаточно богатые традиции исследования категории собственности. В научных исследованиях двух последних десятилетий сформировалось не меньше чем три подхода к анализу генезиса собственности. Первый подход характеризуется тем, что «отношения собственности» - это непосредственно базовое понятие, «собственность» - категория экономическая и является основанием самой себя, субстанцией построения общественных отношений (В. Останин, А. Смирнов, К. Хубиев и др.).

В пределах второго подхода собственность рассматривается как явление, привнесенное государством или правом. Многие представители названного направления провозглашают идею правового происхождения собственности: «идея собственности принадлежит к сфере права и вне ее не имеет ни силы»; «собственность является комплексом разнообразных юридических общественных отношений, научное знание которых отображается в логической форме системы правовых категорий». Представители такого подхода квалифицируют собственность как отношение надстройки и включают его в категории прав (В. Шкредов, А. Чепуренко и др.). Это направление было достаточно широко поддержано в науке, что обусловило формирование экономической теории прав собственности.

Исторические истоки институциональной экономической теории прав собственности базируются на двух подходах. Первый берет начало от Кодекса Наполеона, который лег в основу гражданских кодексов ряда европейских стран и трактуется как континентальная правовая традиция, которая приобрела значительное развитие в трудах выдающихся зарубежных экономистов середины и второй половины XX в., таких, как Г. Коуз, А. Алчиан, Г. Демзсец, Д. Норт, О.Е. Вильямсон и другие. 
Существенными характеристиками континентальной традиции были: рассмотрение собственности как вещи и формальная неделимость имущественных прав. Второй подход реализовывался в пределах англосакской традиции, для которой характерным был учет многомерности блага, которое является объектом собственности во времени и пространстве.

Идеологом теории прав собственности считают А. Алчиана, а ее разработчиками признают таких экономистов, как Г. Коуз, И. Барцель, Г. Демсец, Г. Познер, С. Пейович, Д. Норт, Т. Еггертссон, О. Вильямсон, Е. Фуруботн и некоторых других.

Общая идея заключается в том, что не ресурс выступает воплощением собственности, а «пучок или часть прав на использование ресурса, - вот что составляет собственность». В Гражданском кодексе (ГК) Украины в ст. 316 право собственности определено «как право личности на вещь (имущество), которое она осуществляет в соответствии с законом по своей воле, независимо от воли других лиц», которая отвечает триаде римского права. Тем самым разработчиками ГК не полностью учтено современное достояние экономической теории в сфере спецификации прав собственности не только по содержанию (пучок или часть прав на использование, а не права на вещь), но и по форме, поскольку в ст. 317 ГК содержание прав собственности определено в пределах прав владения, пользования и распоряжения имуществом.

Права собственности представляют собой такие санкционированные (экономические, юридические, этические) и принятые в обществе (формальные $и$ неформальные) поведенческие отношения между экономическими агентами, которые определяют перечень возможных приемов использования ограниченных ресурсов как исключительную прерогативу отдельных индивидов или групп. Таким образом, экономические правила предопределяют появление существенного ядра прав собственности, то есть его исключительности.

Как один из вариантов способа структуризации прав собственности можно назвать такие виды правомерности: 
- $\quad$ право пользоваться вещью;

- $\quad$ право получать от пользования вещью доход;

- право изменять физическую форму и субстанцию вещи;

- $\quad$ право передавать отмеченные правомерности другому лицу (дарить, завещать, продавать, передавать на определенное время).

Такой вариант соответствует неоинституциональной экономической теории прав собственности, которая фокусирует внимание на правах физических действий С вещами. С одной стороны, это открывает возможности для реализации прав собственности в границах «одна вещь много владельцев», а со второй - в большей степени соответствует современным тенденциям хозяйственного развития использования собственности как экономического ресурса. Имеются в виду права аренды, лизинга и других ограниченных имущественных прав.

Институциональная теория прав собственности базируется на положении о том, что любой обмен представляет собой, собственно говоря, обмен пучками правомерности. Экономико-правовой (институционный) подход к определению прав собственности со времен римского права решает проблему возможностей и границ спецификации и размывания этих прав. Если предложенная римским правом триада спецификации прав собственности - владение, распоряжение, пользование - и до сих пор употребляется в континентальном праве (даже вопреки идее «абсолютного» права частной собственности, воплощенной в Кодексе Наполеона), то для островного права более употребимым является известный пучок правомерностей А. Оноре. Анализ возможности совмещения триады и пучка прав собственности дал возможность сделать вывод о том, что триада и пучок прав собственности не только не отличаются друг от друга, но и одно включает в себя другое. Потому можно говорить только о разногласиях в традициях островного и континентального права, а не о разных концептуальных подходах в исследовании прав собственности.

Разнообразие характеристик и полезных свойств вещи обусловливает многогранность правил отношения к ней других людей, 
которые принимают форму правомерности. Чаще всего в исследованиях используется один из вариантов определения пучка правомерности, который предложил английский юрист А. Оноре. Он выделил такие правомерности владельца:

- п право владения, суть которого - в защищенной возможности осуществления физического контроля над вещью. Данная правомерность лежит в основе исключительности прав собственности. Если отсутствует право владения (независимо от того, кому оно принадлежит), то лишним становится и сам термин «собственность»;

- $\quad$ право пользования относится к вещам, которыми владеют как с непосредственной, так и опосредствованной полезностью;

- право управления включает возможность определения направления, в котором может быть использована данная вещь, а также определен круг и порядок доступа лиц к ресурсу;

- право на доход, которое может возникать вследствие непосредственного пользования вещью (имплицитный доход) или использования вещи другими индивидами (доход в явной фрорме денежной или натуральной);

- право на капитал (или капитальную стоимость), которое допускает возможность дарения, продажи, изменения фрормы или уничтожения блага. В данное право входит часовой аспект отношений между людьми по поводу того или другого блага;

- право на безопасность, или иммунитет от экспроприации, которая предусматривает защиту от вредного действия на поток доходов в виде экспроприации, даже при условии наличия компенсационной системы;

- $\quad$ право на передачу вещи наследникам. Существование данного права обусловлено тем, что после смерти данная вещь перестает быть ценной для ее обладателя, однако интерес к ней как активу сохраняется для других. Поскольку это так, то данная правомерность может быть ценной для того, кто является завещателем, в той степени, в которой с помощью ее использования может быть осуществлен обмен правами; 
- бессрочность, которая означает отсутствие каких-либо временных границ в осуществлении правомерности. Чем длиннее часовой горизонт, тем выше ценность данного актива для его обладателя;

- запрещение на вредное использование. В сущности это «негативное» право, которое не позволяет использовать вещь так, чтобы это было связано с вредом, который наносится имуществу других агентов. Данная правомерность является основанием для разграничения исключительности права и его абсолютности;

- ответственность в виде взыскания. Эта правомерность дает возможность отчуждать вещь для уплаты долга. Данная правомерность также позволяет использовать имущество как залог;

- право на остаток, то есть обязательность возвращения переданных кому-то правомерностей касательно блага по окончании срока соглашения или потери силы последней.

В связи с перечисленными правомерностями необходимо сделать несколько пояснений.

Часть правомерностей может выступать только в кластере (или вместе), то есть являются взаимодополняемыми и не имеют ценности друг без друга. Например, право на доход бессмысленное, если не существует правомерности «безопасность», поскольку низкая достоверность получения дохода ввиду отсутствия безопасности означает фриктивность данной правомерности. Право пользования часто объединяется с правом на доход, особенно если трудно найти отличие между явным и неявным доходом. Данная правомерность оказывается неотъемлемой частью права на капитальную стоимость, поскольку ценность последнего определяется через дисконтированный поток ожидаемых доходов.

Следует различать исключительность самих прав собственности и возможность их передачи. В частности, фрермер может владеть исключительным правом на фризический контроль по отношению к участку земли, однако продать или заложить его он не может. Существует принципиальное отличие между исключительным и абсолютным правом собственности. Исключительность права для данного человека может 
существовать при наличии девятой правомерности, тогда как именно данная правомерность не позволяет говорить о правах собственности как абсолютных.

Таким образом, права собственности - это система взаимосвязанных элементов, причем некоторые из них являются взаимодополняющими и не имеют ценности один без другого. Например, ограничение прав на получение дохода от ресурса может привести к полной потере заинтересованности в его использовании. Абсолютное и относительное право собственности характеризуется по отношению к членам общества: абсолютное - по отношению к остальным всем членам общества; относительное - по отношению к некоторым членам общества. Экономические права могут быть формальными и неформальными, потому и права собственности могут быть правами де-юре и де-фракто.

Институциональная экономическая теория прав собственности связывает происхождение собственности с редкостью, ограниченностью благ и возможностью их альтернативного использования. Редкость порождает ограниченность претендентов на их использование. Для устранения конфликта между сторонами, которые пытаются получить право на использование ограниченного ресурса, что может привести к его избыточному потреблению и исчерпанию, устанавливаются исключительные права, которые предусматривают полное запрещение осуществления определенной правомерности до получения согласия от субъекта права собственности, который может принимать указанное решение. Именно субъектное право принимать указанное решение, согласно с экономической теорией прав собственности, лежит в основе выделения частной, коммунальной и государственной форм собственности.

Экономика частной собственности означает, что право принимать решение о применении определенной правомерности принадлежит отдельному субъекту ведения хозяйства. Потому и пучок правомерностей может быть сконцентрирован у отдельной личности. В системе государственной или коллективной собственности право принимать 
решение размыто, пучок правомерностей распределен между разными сфрерами управления, поэтому режим исключительного права не может быть утвержден и поддерживаться ни государством, ни муниципальной властью, прежде всего, из-за неоднородности, неопределенности самого субъекта прав. То есть трудно установить, которая из ветвей бюрократического аппарата принимает решение о предоставлении определенной правомерности экономическим агентам и кто несет экономическую ответственность за последствия ее использования с точки зрения субъекта собственности (группы, общества, государства). Потому интерпретация утверждения, что государство может устанавливать и поддерживать режим исключительного права, на наш взгляд, является неубедительной. Как свидетельствует недавнее прошлое стран, где господствовала государственная собственность, государство оказалось неспособным устранить конфликт между субъектами ведения хозяйства (государственными предприятиями) по вопросам использования ограниченных ресурсов, которое привело к их избыточному (а иногда и варварскому) использованию и исчерпанию (например, оценивание результатов труда предприятий по валовым показателям использованного металла, материалов, фрондов, освоенных (потраченных) средств в строительстве и т. п.) и установление исключительных прав, которые предусматривали бы запрет на осуществление той или другой правомерности априори, до получения согласия владельца, который имеет право принимать решение, то есть граждан общества.

Именно получение возможности устанавливать и поддерживать режим исключительных прав самими субъектами собственности с помощью государства, а также путем установления и соблюдения социальных норм и правил, которые базируются на принципах равноправия и конкурентности разных форм собственности, мы считаем главным достижением при переходе от планово-распределительной к рыночной экономике. С одной стороны, разгосударствление, приватизация и спецификация прав собственности становятся материальной основой (предпосылкой) формирования рыночной экономики, а из другого - 
создание экономической, политической, правовой, психологической среды, в которой господствует уважение к собственности в любой форме, и ее защищенность со стороны общества и власти свидетельствуют о становлении рыночного характера экономики.

Именно лишение определенных субъектов свободного доступа к каким-то благам рассматривается в экономической теории прав собственности как спецификация последних, то есть для одних субъектов спецификация означает установление определенных прав пучка правомерностей, а для других - полное или частичное лишение их. Следовательно, основная цель спецификации прав собственности заключается в изменении поведения хозяйствующих лиц таким образом, чтобы они принимали оптимальные решения относительно ограниченных ресурсов, потому что на владельца блага в конечном счете приходятся все позитивные и негативные результаты использования последнего, в результате чего он оказывается заинтересованным в самом полном их учете при принятии решений относительно блага. Однако это возможно при условии, что все спецификации пучка правомерностей находятся в исключительном пользовании определенного экономического агента. Но если отдельные правомерности находятся в пользовании разных субъектов ведения хозяйства, то такая ситуация не является гарантом эфффективного использования собственности (ограниченных ресурсов), то есть возникает проблема контроля со стороны владельца.

В процессе обмена прав собственности на те или другие блага они должны быть переданы тем лицам, для которых составляют наивысшую ценность, а рыночная инфраструктура (например, фондовая биржа) является тем механизмом, который обеспечивает такую передачу. С ее помощью ограниченные ресурсы эффрективно распределяются в те сферы деятельности, где обеспечивается наиболее рентабельное их использование. Специфика прав собственности в переходной экономике проявляется в том, что названные права перераспределяются от субъектов, которые их используют менее эффрективно или не используют вообще, к тем, кого принято называть «эффективный владелец». 
Экономическая теория прав собственности не затрагивает вопроса о качественном социально-экономическом результате и о качественных достижениях в количественной концентрации прав собственности, характерных для неконкурентных рынков или корпоративных прав. Ведь попытка довести количественное накопление акций до контрольного пакета ставит определенную социально-экономическую цель концентрацию прав собственности, которая трактуется как экономическая власть.

Экономическая власть - это, во-первых, власть в сфере экономической деятельности, во-вторых, под ней может пониматься власть, которой достигают с помощью экономических средств, в-третьих, она оказывается там, где сосредоточивается основная часть дохода.

Если операционные правила определяют взаимоотношения между отдельными индивидами по поводу использования определенного редкого ресурса и деления дохода, то от правил коллективного действия зависит порядок изменений и применения операционных правил. К общенациональным правилам принадлежат право доступа и право получения выгоды (дохода). К правилам коллективного действия относят права управления, исключение и отчуждение.

Не существует единственной классификации правил, а только обнаружена Д. Нортом иерархичность системы правил (изменение в правилах низшего порядка может осуществляться при неизменных правилах высшего порядка), как не существует $и$ общепринятой классификации прав. Но в зависимости от критерия, за которым будут классифицироваться правила, можно говорить об определенной классификации правомерностей. Следуя этому утверждению, экономические правила - это экономические права, концентрированное выражение которых воплощается в правах собственности. Согласно с иерархией системы правомерностей, предложенной Е. Остром, экономическая власть сводится к обеспечению ее субъектов определенным уровнем распоряжения собственностью и доходом от ее использования. 
Особенность приведенной классификации правомерностей заключается в том, что выполнение каждой следующей правомерности предусматривает выполнение предыдущей. Такая система имеет определенную логику: если предположить, что индивиды специализированы, то установление категории тех из них, которые могут получить право доступа к определенному ресурсу, определяют направления использования последнего, а не наоборот. То есть подтверждается подмеченная Д. Нортом иерархичность системы правил относительно меры спецификации прав собственности.

Права собственности определяют экономическое или материальное положение каждого индивида относительно других членов общества. Они создают условия для децентрализации принятия решений. Конституция порядка выступает как результат многосторонних контрактов с целью уменьшения усилий многосторонней координации принятия решений, в отличие от другой крайности - полной централизации в принятии хозяйственных решений. Но в чистом виде это никогда не удавалось даже в советской экономике или в армии.

Важным условием рыночных преобразований в странах с трансформационной экономикой является спецификация прав собственности, то есть закрепление за каждой правомерностью четко определенного владельца. Это значит, что когда у каждой правомерности есть свой исключительный владелец, право собственности полностью специфицировано, а доступ к нему других субъектов ограничен.

Спецификация прав собственности как процесс находит отображение в наборе правил, которые существенно зависят от конкретного ресурса и исторических условий

Собственность является отношениями между людьми по поводу отчуждения-присвоения вещей как последовательное изменение процесса отчуждения на состояние присвоения со следующим переходом в процесс присвоения и состояние отчуждения. То есть самой существенной чертой отношений собственности является присвоение. Если субъектом отношений по поводу присвоения выступает индивид, то это означает 
установление верховенства его воли относительно вещи. Но это возможно лишь тогда, когда такое отношение лица к вещи будет общепризнанным. Если рассматривать другие формы собственности, то присвоение будет заключаться в превращении вещи на объект воли коллектива или государственной воли. В этом волевом моменте и заключается специфическая определенность присвоения. Такое определение спецификации прав собственности формируется из концепции собственности как сложного пучка правомерности, причем правомерность на один и тот же ресурс может принадлежать разным людям.

Под спецификацией прав собственности нужно понимать создание в той или другой фрорме режима исключительного использования вещи. Этот режим предусматривает: 1) определение субъекта, который владеет таким исключительным правом; 2) установление объекта, относительно которого соответствующий состав правомерностей может быть реализован; 3) выяснение механизма присвоения прав и их передачи.

Процесс спецификации прав собственности отображается в перечне правил, который заметно отличается как относительно конкретного ресурса, так и относительно исторического периода и места. В экономической литературе не замеченным остается тот исторический факт, что основы правомерностей и спецификации прав собственности были заложены в Российской империи еще в начале XIX в. комиссией по кодификации под руководством М.М. Сперанского.

Свод законов Российской империи была результатом уникальной систематизации законодательства, куда были включены нормы римского права, дано определение целому ряду новых понятий и институтов, которые заложили основы регуляции прав собственности, которые не приобрели последующего развития и использования в российской экономической науке, но активно исследовались на Западе.

Факторами, что ограничивали права собственности, были такие:

1) право участия в пользовании и получение выгод от чужого имущества;

2) право на выгоду в чужом имуществе; 
3) право собственности на наследственные имения, полученные по завещанию;

4) право собственности на имения, которые обжаловались на праве майоратов в западных губерниях;

5) право владения и пользования, отделенные от прав собственности;

6) право распоряжение, отделенное от прав собственности.

Для понимания и раскрытия сущности прав собственности интересным является определение «право постороннего участия в выгодах имущества», которое было двух видов: общее и частное. Оно считалось общим, если право «участия в выгоде» имущества устанавливалось для всех лиц; частным, когда оно устанавливалось в интересах какого-либо одного из частных владельцев.

Права собственности определяют те действия по отношению к объекту, которые разрешены и защищены от препятствований их осуществления со стороны других людей. С этой точки зрения можно говорить о том, что ситуации выбора определяются правами собственности.

Права собственности - это такие разрешенные и защищенные от препятствований для их осуществления возможные способы использования ограниченных ресурсов, которые являются исключительной прерогативой отдельных индивидов или групп.

В историческом плане можно выделить два подхода к определению и исследованию собственности: 1) как внутри себя не распределено целое, абсолютное и неделимое; 2) как набор правомерности, которая является открытым множеством.

Первый подход основан на континентальной правовой традиции, представленной в Кодексе Наполеона. Второй подход реализован в рамках англосакской традиции. Значимость второго подхода обусловлена возможностью дифференцированного отношения к вещи экономических агентов в соответствии с их сравнительным преимуществом в ее использовании. 
Последствиями развития континентальной традиции является рассмотрение собственности как вещи; фрормальная неделимость имущественных права; ограниченные возможности использования принципов прецедентного прав ввиду формальной неделимости собственности.

\section{6. Изменение прав собственности}

Изменение прав собственности является фрундаментальным условием трансформации экономики. Спецификация разнообразных прав собственности определяет демократический цивилизационный характер современной экономики.

Право собственности, с одной стороны, может рассматриваться как важный институт, а с другой - как отдельные права, которые являются элементами целостной экономической системы.

В первом случае права собственности являются определенными «правилами игры», регулирующими взаимоотношения между людьми по поводу использования ограниченных ресурсов. С другой стороны, права собственности определяют пучки правомерностей, которые есть в распоряжении того или другого агента. С. Пеевич и Е. Фуруботн определили права собственности как санкционированные поведенческие отношения, которые возникают между людьми в связи с наличием благ и их использованием. Эти отношения определяют такие нормы поведения относительно благ, которых любое лицо должно или придерживаться в своих взаимодействиях с другими людьми, или же нести расходы из-за их несоблюдения.

Господствующая в обществе система прав собственности является такой совокупностью экономических и социальных отношений относительно редких ресурсов, в рамках которой отдельные члены общества противостоят друг другу. Важным условием их институционализации является формирования таких условий, при котором это противостояние имело бы цивилизованный характер. 
Собственность или права собственности нужно отличать от объектов собственности, то есть материальных или нематериальных объектов, на которые распространяются права собственности.

Установление права собственности имеет смысл в условиях ограниченных ресурсов, когда могут возникать консрликты по поводу их использования, тогда права собственности позволяют ограничивать и разрешать эти конфликты. Другими словами, права собственности определяют возможные способы использования ограниченных ресурсов как исключительную прерогативу отдельных индивидов или групп. Права собственности носят многосубъектный (индивидуум, фрирма, государство и др.), многоуровневый характер. Права низшего уровня оказываются объектом права высшего уровня, а также отличаются режимами своего приложения.

Права собственности закрепляются не только государственной властью (законами, судебными решениями и т. д.), но и традициями, обычаями, нормами, а потому действительно является «правилами игры», принятыми в обществе. Поведенческий смысл прав собственности заключается в том, что они стимулируют деятельность, изменяя расходы при разных способах поведения. Например, несанкционированное поведение, продиктованное негативными стимулами, увеличивает расходы своего осуществления за счет возможного наказания. В итоге соблюдение или нарушение правил сводится к актам добровольного экономического выбора, и сами права имеют экономическую ценность.

Права собственности определяются и гарантируются некоторой структурой управления, или порядком, то есть системой норм, а также инструментами, которые защищают этот порядок. Обеспечение порядка может быть чисто внутренним или же устанавливаться ожиданиями специфических внешних последствий. Институциональная экономика имеет дело со вторым случаем, то есть с гарантиями, основанными на санкциях, установленных или законом, или обычаем.

Собственность - это институт, который предоставляет людям свободу распоряжаться ограниченными ресурсами. 
Эта свобода предполагает закрепление определенных прав за владельцем и запрещение другим вмешиваться в реализацию этих прав. Владельцы имеют юридические полномочия действовать или воздерживаться от действий, но без жестких обязанностей делать то или другое, если только они добровольно не взяли на себя обязательства по договору.

Режим частной собственности, которые устанавливают полные права собственности и предусматривает их защиту. Защита от вмешательства частных лиц или органов власти включает запрещение на нарушение владения, вторжение, кражу, уничтожение, вредность, загрязнение, затопление, несанкционированное использование, присвоение, экспроприацию, захват и национализацию. Нарушение прав собственности угрожает привлечением к гражданской, судебной или криминальной ответственности за нанесенный ущерб.

Владелец пользуется наибольшей свободой тогда, когда имеет возможность делать со своими ресурсами все, что не причиняет вреда другим. Это положение называется принципом ограниченной максимальной свободы. Понятие «вред» включает причинение боли, страха, нанесение травмы, потерю дохода или имущества. Правовые нормы, которые применяются для оценки вреда и определения меры ответственности, закрепленные в праве собственности, гражданском, договорном, криминальном праве и т. п., а также в антимонопольном законодательстве и административном праве.

С. Пеевич и Е. Фуруботн утверждают, что права собственности состоят из трех основных элементов: 1) права пользоваться имуществом; 2) права присваивать доход от имущества; 3) права изменять его фрорму, содержание и местонахождение, включая право передачи ресурсов на время или навсегда. Пучок прав, связанных с конкретным ресурсом, обычно состоит из нескольких частей: некоторые права могут быть использованы совместно при открытом доступе, другие могут быть ограничены в присвоении дохода, и, наконец, третьи могут быть частными.

Большое значение для характеристики прав собственности имеет 
процесс их спецификации, а также их размывание. Спецификация прав собственности - это создание режима исключительности для отдельного индивида или группы с помощью определения субъекта права, объекта права, набора правомерностей, которые имеет в своем распоряжении данный субъект, а также механизм, который обеспечивает их соблюдение.

Противоположным процессом является размывание прав собственности, которое имеет место, когда они или неточно установленные и плохо защищенные, или страдают от разного рода ограничений (прежде всего, со стороны государства). Чистый режим частной собственности означает исчерпывающую спецификацию и полную защиту всех правомерностей. Размывание прав собственности, ослабляя их исключительность и отчуждение, суживает возможности экономического выбора агентов и снижает ценность объекта прав. Значит, чем лучше специфицированы и защищены права собственности, тем большую ценность они представляют.

Для понимания спецификации прав собственности важно, кто (какой именно гарант) ее обеспечивает и каким образом осуществляется передача прав (если она вообще допускается).

Когда идет речь о формальных правах, то их, как правило, специфицирует государство. Вместе с тем внутри предприятия, например, те или другие формальные права собственности могут специфицироваться его руководством. Вместе с формальной, возможна безличная спецификация, в основе которой лежит повседневная практика взаимодействия экономических агентов, то есть гарантом выступает любой член группы, который заметил осуществленное нарушение.

Самой сложной фрункцией процесса спецификации прав собственности является предоставление последним свойства исключительности.

Правомерность собственности называется исключительной, если ее субъект в состоянии эффрективно исключить других экономических агентов из процесса принятия решения относительно использования данной правомерности. 
Исключительность того или другого права собственности не означает, что оно принадлежит индивиду, то есть частному лицу. Исключительными правами может владеть группа людей, хозяйственная организация (юридическое лицо), наконец, государство.

Исключительность прав собственности экономически важна потому, что именно она создает стимулы к эффрективному использованию ресурсов: если права собственности субъекта на результат использования его ресурсов не являются исключительными, у него нет стимулов, максимизировать этот результат, поскольку весь он или его любая часть могут добраться другому.

В определенной степени обратным процессу спецификации есть размывание прав собственности. Этим термином выражается практика нарушения исключительности прав, которая приводит к снижению ценности объекта права для субъекта, поскольку поток ожидаемых доходов должен дисконтироваться по высшей ставке процента (что учитывает риск экспроприации). Таким образом, фрактический уровень исключительности той или другой правомерности собственности - это функция от процессов спецификации/размывания прав собственности.

Необходимо сравнить процессы ограничения и расщепления прав собственности. Ограничения налагаются, как правило, в принудительном порядке государством, часто в целях перераспределения прав собственности. Расщепление или дробление прав собственности происходит в форме добровольного обмена, по инициативе самих владельцев. Спецификация прав часто требует больших издержек, поэтому она должна осуществляться в тех пределах, в которых последующий выигрыш от сокращения «размытости» прав, не покрывает связанных с этим понесенных издержек. Поэтому нормальным является существование некоторых ресурсов с плохо или не установленными правами, что может существенно влиять на эффективность экономики в целом.

Система прав собственности включает: общую, коммунальную, частную и государственную. 
Общая собственность (синоним - свободный или открытый, доступ к ресурсу) значит, что ни один из индивидов, которые претендуют на один и тот же ресурс, не находится в привилегированном положении, и никто не имеет прав исключить других с доступа до данного блага. Права на эту собственность плохо определенны, отсутствует режим исключительности и отчуждения собственности. Примерами собственности свободного доступа могут быть грибной лес, озеро, где можно ловить рыбу, парковая зона, пастбище для выпаса скота и т. п.

Такая собственность фактически не требует издержек для своей поддержки, а набор правил, которые регламентируют ее использование, минимальный. Она встречается там, где расходы на спецификацию и защиту прав собственности очень высоки и превышают ожидаемые от спецификации выгоды. Например, трудно проконтролировать, сколько рыб выловили в реке или сколько грибов собрали в лесу. Режим свободного доступа может сохраняться для ограниченных благ. Потому проще всего правило использование ресурса свободного доступа свидетельствует: «первым пришел - первым воспользовался». Например, первый рыбак занял удобное место для лова рыбы у реки, или кто первый пришел, тот занял скамью в парке.

Общая собственность может выступать как средство защиты от естественных монополий. Однако она имеет множество недостатков.

Во-первых, разрывается связь между деятельностью индивида в режиме свободного доступа к результатам его деятельности. Во-вторых, общедоступные ресурсы не могут переходить к тем агентам, которые эффрективнее других ее используют. Преимущества общественного разделения труда и специализации не используются в полной мере. Втретьих, усилия агента тратятся на получение ресурса, реализацию стремления опередить других. Поэтому механизмом рационирования использования ресурсов в условиях общей собственности служит институт очереди. Кроме того, могут вводиться неценовые ограничения, такие как охотничьи сезоны, запрещение на использование определенных орудий лова и т. п. В-четвертых, решения принимаются исходя из близкой 
перспективы, отсутствуют стимулы к инвестированию, используются трудоемкие технологии, а значит, снижается эффеективность.

Коммунальная собственность означает, что исключительными правами собственности на данный объект владеет только часть экономических агентов (определенная группа, община) из данного множества. Примерами коммунальной собственности являются кооперативы разных типов. Это промежуточный вариант между свободным доступом и частной (государственной) собственностью.

Система коммунальной собственности имеет режим исключительности, поскольку свободный доступ к данному ресурсу со стороны аутсайдеров закрыт. Однако в рамках коммунальной собственности может возникнуть эффект свободного доступа, который требует введения правил, которые регулируют доступ к ресурсу инсайдеров.

По сравнению с частной собственностью коммунальная собственность меньше тратит на защиту прав собственности, поскольку возникает эффрект экономии на масштабе, в частности связанный со специализацией на обеспечение режима исключительности. Коммунальная собственность жизнеспособна потому, что основана на общности интересов, которая облегчает решение вопроса о регуляции доступа к ресурсам, уменьшает оппортунистическое поведение в форме уклонения.

Коммунальная собственность имеет и определенные недостатки. Она не защищена от сверхиспользования ресурса со стороны инсайдеров, а значит, включает расходы, связанные с принятием решений о регуляции доступа. В связи с возможностью определенного оппортунистического поведения в виде уклонения при использовании уравнительного принципа деления полученных результатов может возникнуть проблема недоиспользования ресурса и роста издержек оппортунизма. В целом могут возникнуть проблемы принятия решений в группе. Коммунальная собственность может быть разрушена как извне, так и изнутри. Разрушение извне происходит в случае, если расходы защиты прав 
собственности от аутсайдеров оказываются очень высокими (что показывает ситуация с садовыми обществами). Разрушение коммунальной собственности изнутри может быть вызвано ростом численности группы совладельцев, введением новых технологий использования ресурса и т. п.

Оптимальный размер группы можно определить на основе подхода минимизации средних трансакционных издержек. Трансакционные издержки включают расходы обеспечение защиты прав собственности, которые с ростом численности группы уменьшаются, и расходы достижения соглашения и обеспечения контроля, за их выполнением, что по мере роста численности группы растут. Если численность группы незначительная, то она меньше оптимальной, поскольку возможности экономии на масштабе при обеспечении безопасности прав собственности компенсируют рост издержек принятия решений и обеспечения контроля. Напротив, если численность группы большая, она превышает оптимальный уровень, поскольку теперь возможности экономии на масштабе компенсируют рост издержек принятия решений и контроля лишь частично.

Частная собственность устанавливает исключительные права, а значит, снимает институциональные препятствия сверхиспользованию ресурсов. Право частной собственности означает, что отдельная физический или юридический субъект хозяйствования владеет всем пучком правомерностей или его частью. В условиях частной собственности право отчуждения реализуется через рынок. Однако может действовать и размытое право в том случае, когда существует формальный запрет на отчуждение, например, запрет на продажу земли в Украине.

Преимуществами частной собственности является защищенная свобода принятия решений относительно объекта собственности, прямая связь между деятельностью агентов и результатами деятельности, высокая мотивация агентов, использования преимуществ общественной организации труда, возможностей специализации, поощрения инноваций, благоприятные условия для использования неявного знания и принятия на себя риска и ответственности за принятые решения. В целом отмеченные 
преимущества ведут к более эффрективному использованию ресурсов.

Несмотря на указанные преимущества, существуют ограничения на распространение частной собственности. Во-первых, есть существенные расходы на спецификацию и защиту прав собственности, которые определяются как институциональными, так и технологическими фракторами. Защита и спецификация прав собственности может поддерживаться государством, самим субъектом права, социальными нормами, нарушение которых ведет к применению этических, экономических и юридических санкций. Во-вторых, фракторами, которые определяют распространение частной собственности, является степень развития рыночных отношений, господствующая идеология и научные представления, развитие правовой базы и эффективность экономической политики государства, действующие неформальные нормы, доминирующие принципы системы образования, а также других сорер, которые формируют систему ценностей в обществе. Эти факторы могут, как способствовать, так и препятствовать распространению частной собственности в пространственном и часовом аспектах.

Государственная собственность значит, что всем пучком или разными его элементами владеет исключительно государство. Система государственной собственности специфицируется и защищается совокупностью формальных правил и допускает существование режима исключительности доступа к ресурсам, причем не только для аутсайдеров, но и инсайдеров. Распоряжение государственной собственностью осуществляется не непосредственно, а опосредствовано, через политический процесс и многоуровневую систему представителей в виде государственных организаций и их руководителей. Государственная собственность не является отчуждаемой, поскольку ее нельзя свободно продать или ликвидировать какую-то ее частицу. Из-за этого она не поддается расщеплению.

Недостаткам государственной собственности является то, что число владельцев и массив объектов достаточно большой. Возникает необходимость делегирования прав собственности наемным агентам по 
принятию решений по поводу использования объектов государственной собственности. В связи с этим остро встает проблема принципала-агента. Возникает необходимость наличия контрольного аппарата, который минимизирует расходы оппортунистического поведения. В этой системе собственности больше выявляются проблемы общедоступности, поскольку расходы обеспечения соблюдения прав в государственной собственности очень высоки.

Существование государственной собственности оцениваются теоретиками нового институционализма достаточно критически. Деятельность государственных предприятий серьезно страдает от политизации, подчинения внеэкономическим целям. Да, невозможно получить биржевую оценку качества управления государственным предприятием; контроль со стороны владельцев (налогоплательщиков) за поведением управленческого аппарата резко ослабленный; рынок не заинтересован в таких предприятиях, уклоняясь от участия в их реорганизации. Государственные предприятия склонны к накоплению избыточных производственных мощностей и раздуванию штатов, отдают преимущество строительству сооружений в убыток активным элементам капитала, избирают менее рискованные инвестиционные проекты, медленнее реагируют на изменения в спросе, тормозят нововведение. Их менеджеры располагают лучшими возможностями для переключения ресурсов фирмы на свои личные цели, имеют более длительные сроки службы. Кроме того, государственные чиновники могут получать частные доходы из государственной собственности, а это относится к коррупции.

Предлагаются следующие объяснения эффективности режима чистой собственности. Собственность как такова является признаком свободы, с одной стороны, а также способствует сохранению свободы, децентрализуя власть и препятствуя тирании, - с другой.

Права собственности интернализируют результаты использования ресурсов. Интернализация достигается тем, что за владельцем закрепляются непосредственные выгоды и расходы использования ресурсов, что ему принадлежат. Правовые нормы, которые касаются 
вредности и гражданских правонарушений, можно рассматривать как механизм интернализации издержек. При полной интернализации, все прибыли и расходы учитываются владельцем при принятии решений. Исключительность прав присвоения чистой выгоды от использования ресурса стимулирует владельца к максимизации этой выгоды, а это требует предприимчивости и новаторства.

Законы о собственности дают четкое и надежное определение прав владельца, который превращает операции в акты добровольного обмена. Напротив, нечеткие и ненадежные права собственности налагают на участников обмена груз больших информационных издержек и высокой платы за риск. Аналогично договорное право содействует развитию торговли, поскольку гарантирует, что сторона, которая авансирует средства, получит ожидаемую прибыль от операции. Таким образом, права собственности содействуют развитию обмена путем минимизации трансакционных издержек.

Через отчуждение прав (возможности свободной передачи правомерностей) может быть достигнуто оптимальное размещение ресурсов в пространстве и во времени. Действительно, владелец может передать благо в ходе обмена потому агенту, для которого оно будет иметь большую ценность (продать по максимальной цене), а значит, происходит движение к эффрективному размещению ресурсов. Кроме того, права собственности принуждают агентов учитывать не только краткосрочные, но и долгосрочные последствия при принятии решений, то есть они защищают интересы будущих поколений.

Дробление частной собственности означает отделения некоторой правомерности, их комбинацию и рекомбинацию, которая открывает возможности для кооперации и специализации в соответствии со сравнительными преимуществами агентов. Потому перераспределение прав среди разных владельцев способствует росту производительности труда и максимизации совокупного богатства.

Расширение прав на распространения частной собственности на теперешние и будущие ресурсы указывает: в обществе нет никому не 
принадлежащих, ничейных ресурсов, а это значит, что владельцы владеют правами и несут ответственность за их использование в пределах своей правомерности.

Главное преимущество системы частной собственности заключается В том, что благодаря свободе обмена и комбинирования прав собственности она предоставляет широкие возможности для создания наиболее эффрективных организационных фрорм хозяйственной деятельности.

В реальной действительности функционируют смешанные режимы прав собственности при доминировании тех или иных ее форм. В целом при принятии решения о том, в какой собственности должен находится ресурс: в частной или государственной, было бы абсурдно считать, что только в частной. При выборе форм институциональных изменений все права собственности должны быть установленными и принятыми во внимание.

\section{7. Трансформация прав собственности в условиях} институциональных изменений

Одной из наиболее важных составляющих концепции внешних эфрфектов в процессе институциональных изменений, является сравнительный анализ таких режимов использования ограниченных ресурсов как свободный доступ, коммунальная собственность, частная собственность и государственная собственность.

Свободный доступ (общая собственность) и перекрестные внешние эфффекты. Проблема определения прав собственности возникает только тогда, когда на один и тот же объект претендуют несколько индивидов. Потребление (использование) его является конкурентным, то есть увеличение потребления одним человеком уменьшает доступность данного объекта, для другой.

Свободный доступ - ситуация, в которой ни один из экономических агентов не может отстранять других от доступа к данному благу. 
В результате существования открытого доступа к ограниченному ресурсу возникает явление «сверхиспользования ресурса». Проблема свободного доступа, который вызывает сверхиспользование ресурсов, обусловлена тем, что каждый из субъектов, которые принимают решение, присваивает выгоды от использования ресурсов непосредственно, тогда как груз издержек, связанных со сверхиспользованием, распределяется между всеми экономическими агентами.

Такая постановка вопроса делает необходимым, прежде всего, рассмотрение собственно модели свободного доступа, которая позволит обнаружить особенности эксплуатации ресурсов, которые противоречат принципам эффективности, отображенным в неоклассических моделях. Дальше на основе обнаруженных особенностей можно сформулировать условия возникновения, сохранения или устранения режима свободного доступа.

Джеймс Бьюкенен и Гордон Таллок считали, что последствиями воссоздания режима свободного доступа является превращение окружающей среды в общую собственность, порождающую взаимные экстерналии. Однако это не ведет автоматически к изменению системы собственности и соответственно модификации режима рационирования (использование ценовой или другой системы), если расходы спецификации прав собственности и их защиты сравнительно высоки, то есть если чистая ожидаемая ценность результата институциональных изменений для всех экономических агентов оказывается малой или равной нулю.

Таким образом, в результате спецификации прав собственности производство в расчете на единицу использованного ресурса должно увеличиться, однако часть ресурсов теперь будет использоваться для обеспечения соблюдения режима исключительных прав.

Коммунальная собственность - режим использования ограниченных ресурсов, в рамках которого исключительными правами владеет группа людей.

Система коммунальной собственности допускает наличие момента 
исключительности

относительно

соответствующего

набора

правомерности. Однако исключаются из множества обладателей правомерности те экономические агенты, которые не входят в данную группу. Таким образом, отдельный человек владеет исключительными правами собственности только как член общины, следовательно, в рамках отношения к другим членам общин. Такая система прав собственности имеет важные поведенческие последствия, которые могут выражаться в разных формах.

Во-первых, если член данной общности (семьи, села, общины и т. п.) не владеет исключительным правам на доход и деление полученных продуктов осуществляется на основе уравнительного принципа, то в условиях неопределенности возникает проблема недоиспользования ресурса, поскольку каждый обладатель прав на часть продукта будет рассчитывать на другое при производстве общего продукта.

Во-вторых, если принцип деления будет установлен в соответствии с потраченными усилиями, то возникает проблема сверхиспользования ресурса. Таким образом, в рамках коммунальной собственности может возникнуть эффрект свободного доступа, который делает саму систему коммунальной собственности потенциально неустойчивой.

В-третьих, систему коммунальной собственности можно рассматривать в терминах распределительной демократии, когда решение об использовании ресурса тем или иным способом определяется с помощью голосования, поскольку, таким образом, агрегируются преимущества и возникает решение, которое в первом приближении можно рассматривать как выражение общественного интереса.

Анализ коммунальной собственности позволяет обнаружить проблему поиска одного из фундаментальных компромиссов, связанных с критериями отбора наиболее эффективных способов организации и поведения. Если рассматривать группы как объект анализа, то наиболее эффективным будет поведение человека в соответствии с собственными интересами. Вместе с тем, если принимать во внимание взаимодействие между группами, то при определенных условиях группа может быть более 
жизнеспособной, если условия ее выживания и благополучия являются аргументом в целевой функции отдельного члена данной группы.

Система коммунальной собственности не исключает возможности передачи ее частицы от одного человека к другому. В то же время в отличие от режима частной собственности эта передача может быть обусловлена специальными требованиями, которые непосредственно связаны с условиями входа-выхода в общность, которая является совокупным субъектом прав собственности. Например, это может быть условие в виде согласия других членов производственного кооператива на передачу прав другому лицу или определение совокупности свойств, которым должно отвечать то или другое лицо. Данное условие может рассматриваться как часть процедуры выявления преимуществ нового участника для недопущения роста издержек принятия решений.

Хорошо известен железный закон олигархии, в соответствии с которым: «Организация, которая порождает власть выбранных над избирателями, уполномоченных над теми, которые уполномочили, делегатов над теми, кто их делегировал».

Именно в изменении характеристик группы (увеличение численности, разнородности и нестабильности) заложен аргумент о неустойчивости данного режима прав собственности и трансформации его в систему или частной, или государственной собственности. Реакцией на такую проблему является установление свободного режима покупки и продажи титулов собственности как свидетельства прав на долю имущества корпорации, переход от солидарной к ограниченной ответственности.

Система частной собственности значит, что право принимать решение насчет реализации той или другой правомерности принадлежит отдельному экономическому агенту. Соответственно пучок правомерности на определенный ресурс также может быть сконцентрирован у одного человека. Частная собственность - режим использования ограниченного ресурса, при котором исключительными правами владеет отдельный индивид.

Режим исключительности может поддерживаться: 1) государством; 2) 
самим субъектом права; а также 3) социальными нормами. Каждая из этих норм может быть выражена в терминах издержек или негативных выгод, что обусловливает формирование соответствующей структуры стимулов у экономических агентов.

Чем больше гарантированы права частной собственности, чем в большей степени отдельная правомерность сконцентрирована у одного экономического агента, тем выше уровень мотивации, которая обусловливает эффективное использование ресурса. Именно данный режим обеспечивает наиболее жесткую связь между теми решениями, которые принимаются отдельным индивидом и получаемыми результатами. Он обеспечивается путем получения и обработки информации, которая существует в рассеянном виде среди участников хозяйственного оборота. Отсюда, собственно, идея об эфффективности использования ресурсов в системе частной собственности, рациональности экономических агентов.

Более сложным оказывается соотношение между системой частной собственности и рынком. Использование механизма цен связано с издержками, в частности, на защиту и спецификацию прав собственности. Вот почему в итоге возникают вертикально интегрированные фрирмы, в рамках которых также целиком возможно осуществление прав частной собственности. Однако в результате того, что в представлении экономистов система рынков крепко срослась с системой частной собственности, появилась идея рассматривать внутрифирменные трансакции в терминах внутрифрирменных рынков ресурсов (в частности, рынка труда и капитала).

Рынок допускает существование и реализацию правомерностей, которые обычно ставят на вершину иерархии, - право отчуждения, или право на капитальную стоимость. Однако права частной собственности могут существовать, в принципе, и в случае соблюдения формального запрета на отчуждение - в виде исключительного права на пользование, владение, доход, управление и т. п. В таком случае мы будем иметь дело с «размытым» и ограниченным правом частной собственности. Полный или 
частичный запрет на реализацию правомерности в режиме частной собственности может возникать от государства. Государство может принимать участие в процессе размывания прав частной собственности и непрямо: отстраняясь от обеспечения их защиты.

Несмотря на очевидные преимущества данной системы прав собственности в плане мотивации, способов принятия решений, использования локального знания, существуют достаточно много препятствий для повсеместного ее распространения. Идет речь о расходах на защиту и спецификацию прав частной собственности, которые, в свою очередь, определяются существующей технологией применения насилия, а также процедурами и средствами измерения полезных свойств благ.

Степень распространения системы частной собственности в значительной степени зависит от идеологических установок, которые сфрормировались в обществе, нормативных взглядов на мир. Если доминирующим оказывается представление о нерушимости прав частной собственности, то следствием этого является экономия на трансакционных расходах, связанных с защитой прав частной собственности. Вот почему при объяснении соотношения между разными системами прав собственности необходимо учитывать фракторы, которые влияют на формирование системы ценностей.

Государственная собственность - режим использования ограниченного ресурса, при котором исключительность доступа существует не только для аутсайдеров, но и инсайдеров.

При этом исключительность обязательно должна быть отображена в системе формальных правил. Следуя логике нового институционального подхода, права государственной собственности должны существовать там, где, с одной стороны, возможно, обеспечить режим исключительности, а с другой - сравнительные преимущества частной или коммунальной собственности выражены недостаточно.

Институционное изменение, в рамках которого права частной или коммунальной собственности трансформируются в права государственной собственности, называется национализацией. Обратный процесс - 
приватизация. Если приватизация осуществляется с помощью изменения реальной правомерности при постоянной формальной правомерности, то этот процесс можно рассматривать как спонтанную приватизацию. Пример потому - использование сотрудниками научно-исследовательских и академических институтов имущества, которое фрормально находится у государства.

Права коммунальной собственности необязательно должны быть отображены в системе формального права, поскольку режим коммунальной собственности может поддерживаться в мире, где обмен персонализировался и защита контрактов со стороны специализированного агентства не нужна (телефоны, телефаксы, компьютеры и т. п.).

В зависимости от степени распространения системы государственной собственности, а также от ряда других фракторов (в частности, организации системы контроля) возникает существенное отличие между правами государственной собственности де-юре и этими же правами де-фракто. Если фрормально ресурсы находятся в государственной собственности, то фрактически целиком может осуществляться режим свободного доступа к коммунальной или частной собственности. Данная ситуация лишь будет определять: а) набор правомерностей, которые могут реализовать экономические агенты; б) особенности технологии передачи правомерностей от одного экономического агента другому.

Наглядный пример - права собственности на государственные предприятия. В отличие от производственных обществ голос одного работника в определении способа использования ресурсов, которые находятся в государственной собственности, бесконечно мал, так что его эффектом можно пренебрегать при объяснении поведения отдельного работника. С этой точки зрения он напоминает мелкого акционера корпорации открытого типа, в которой при отсутствии специальных контрактных мероприятий, которые ограничивают оппортунистическое поведение менеджеров, последние занимают доминирующее положение. 
Однако в отличие от корпорации риск потерять кресло в результате недружелюбного поглощения у государственного чиновника оказывается существенно ниже, а возможности продать свою частицу другому человеку - меньше. С этой точки зрения права на часть государственной собственности отдельного избирателя менее ликвидны, чем права на долю собственности корпорации открытого типа.

В итоге возникает тенденция к стихийной приватизации государственной собственности. Более того, когда идет речь об атрибутивных характеристиках государства, связанных со сравнительными преимуществами осуществления насилия (на законной основе), можно говорить о приватизации самого государства, в частности использование насилия или его угрозы в личных целях.

Таким образом, существование в долгосрочном плане разных фрорм собственности - частной, коммунальной, государственной и свободного доступа - их анализ с помощью трансакционных издержек, имеет важное методологическое и нормативное значение, и позволяет преодолеть ограниченность неоклассического подхода.

Как известно, суть его заключается в том, что на основании сравнения реальной ситуации с недосягаемым идеалом (определенным как Паретто-оптимальное размещения ресурсов с помощью теории общего равновесия) приводят к выводу о необходимости вмешательства государства в случае возникновения провалов рынка, вызванных возникновением внешних эффректов, «проблемой безбилетника» или повышением прибыльности. Следовательно, имплицитно предусматривается, что вмешательство государства однозначно будет связано с Парето-улучшением. В то же время в остальных всех случаях считается, что право частной собственности является единственно возможным.

Предусматривается, что только приватизация может решить все проблемы неэффективности функционирования экономики, хотя для этого необходимо оценить, сколько будет стоить обеспечение спецификации и защита прав собственности, во избежание синдрома «революции 
ожиданий». Учет возможных издержек целиком может привести к выводу о преимуществе сохранения статус-кво.

В связи с этим нужно заметить, что нельзя выбирать как точку отсчета одну из фрорм собственности, рассматривая ее как эталон и тем самым поневоле подводя к выводам относительно необходимости приватизации, национализации или коммунализации. Этот вывод полностью соответствует тезису, сфрормулированному относительно значения нестандартных форм контрактации в экономии на трансакционных (а также суммарных - производственных) расходах, которые с точки зрения неоклассического подхода рассматриваются как проявление монополистических тенденций, однозначно связанных с нарушением критерия Паретто-оптимальности.

\section{8. Изменение внешних эфффектов}

Внешние эфффекты - это величина полезности или издержек, которые не нашли отображения (не специфицированные) при заключении контрактов.

В неоклассической экономической теории внешние эффректы рассматриваются как следствие или форма проявления провала рынка, или механизма цен. То есть внешние эффректы - это полезность или расходы, которые не учитываются в системе цен. Вместе с тем рассмотрение разных форм координации действий экономических агентов, которые владеют как сравнительными преимуществами, так и изъянами, показывает, что включение в определение понятия цены необязательно, поскольку возможны другие способы учета выгод и издержек (в неценовых компонентах контрактов).

Внешние эффректы могут быть позитивными и негативными. Они создают отличие, с одной стороны, между общественными и частными выгодами (для позитивных внешних эффектов), а с другой - между частными и общественными издержками (для негативных внешних эфрфектов). 
В неоклассической экономической теории рынок принято рассматривать как условие фрормирования цен и механизм, который обеспечивает эффрективное размещение и использование ресурсов. Одновременно относительные цены являются источником информации для экономических агентов, которые принимают решения. Поскольку предусматривается, что внешние эффректы возникают тогда, когда не все выгоды или расходы отображены в системе цен, это свидетельствует о нарушении принципа оптимума размещения ресурсов, а значит, об их неэффективном использовании (относительно условий Паретооптимальности). Другими словами, внешние эффректы отображают недоиспользование теоретически возможных выгод от добровольного обмена, что связано с ненулевыми трансакционными издержками.

С позиций институционализма многообразие форм взаимодействия между экономическими агентами выражается в разнообразии внешних эффректов. Они могут классифицироваться за целым рядом критериев.

В зависимости от особенностей возникновения внешние эффеекты могут быть потребительскими, технологическими или денежными.

Потребительский внешний эффрект - это экстерналия, возникающая на основе неотъемлемых один от другого прямых фрункциональных зависимостей полезности от количества употребленного блага для одного человека и обратной функциональной зависимости для другого человека.

Примером потребительской экстерналии является шумовое влияние, которое возникает возле железных и автомобильных дорог, которое негативно влияет на полезность людей, живущих в домах поблизости.

Технологический внешний эффект - это экстерналия, что возникает на основе существования технологической зависимости выпуска одного экономического агента от объема товаров или услуг, которые производятся другим экономическим агентом. Как пример негативного технологического внешнего эфрфекта можно привести ситуацию взаимодействия производства автомобилей и топлива для них.

Денежный внешний эффрект - это экстерналия, что возникает в результате влияния на величину дохода или издержек одного 
экономического агента: объемов производства, ценовой политики, рекламы и других приемов конкуренции, другого экономического агента.

Образцом такого типа внешнего эффректа является ситуация, которая возникает на конкурентном рынке, когда поведение одной фрирмы негативно влияет на уровень среднего дохода и соответственно экономической прибыли другой фрирмы. Данная ситуация может быть интерпретирована как многосторонняя денежная экстерналия.

При заключении контракта также возникают эффекты (экстерналии) для обеих сторон, по поводу обмена правами собственности на соответствующий товар. В связи с этим можно выделить внутреннюю и внешнюю экстерналии. Внешние экстерналии - такие эфффекты, которые являются внешними не только по отношению к данному контрактному соглашению, но и по отношению к группе субъектов, которые принимают участие в контракте. Внутренние экстерналии - такие эфрфекты, которые являются внешними по отношению к данному контрактному отношению, но внутренними по отношению к группе, которая принимает участие в контракте.

Возможный негативный (позитивный) побочный эффеект может распространяться не только на потребителей данного товара, но и на других людей, которые не принимают участие в операциях по поводу данного товара (услуги). Таким образом, если для одних потребителей, даная экстерналия является внутренней, то для других людей - внешней.

Результаты влияния негативных и позитивных внешних эффектов симметричны, изменяется только «знак», потому анализируются только внешние эффректы.

Проблемы внешних эффректов начались с анализа ситуаций, когда один экономический агент оказывает вредное влияние на другого экономического агента, что и есть побочным результатом его основной (производственной) деятельности. На основе этого обстоятельства вредное влияние интерпретировалось как нарушение принципа эфффективности (иногда вместо термина «эффективность» используется понятие справедливости, которое характерно для судебной практики) и 
требовало вмешательства государства. В итоге предлагались разные варианты:

а) возложить ответственность за причиненный убыток на того, кто его причинил;

б) установить налог для производителя вредного влияния на других, величина которого будет находиться в функциональной зависимости от величины нанесенного вреда. Поскольку последнее является вроде бы побочным результатом его основной деятельности, то возможно построение функциональной зависимости ответственности за убыток на основе выпуска основного продукта (или услуги);

в) разработать график работы производителя и, соответственно, размер убытка, который наносится и т. п.

Ключ к решению данной проблемы дает так называемая теорема Коуза. Общее содержание теоремы заключается в том, что в конце концов неважно, кто сначала будет владеть правом собственности на ресурс. Важно то, что в итоге правом собственности на ресурс будет владеть тот, кто больше его ценит. Согласно с теоремой Р. Коуза, независимо от того, как распределены права собственности, окончательное деление прав позволяет максимизировать общественное благосостояние. Единственным отличием являются результаты деления дохода или благосостояния между заинтересованными лицами.

С учетом того, что количественная оценка общественного благосостояния - достаточно сложный и даже спорный (с точки зрения самой постановки) вопрос, можно ограничиться следующим формулировкам теоремы Коуза:

Если трансакционные расходы равны нулю, то окончательное размещение ресурсов Паретто-оптимально независимо от первичного распределения прав собственности.

При устранении внешних эффектов проблема заключается в поиске такого механизма отбора институциональных соглашений, который позволял бы учитывать максимальное количество значимых для соответствующей ситуации выгод и (или) издержек. Если выбранная 
форма институционального соглашения способствует увеличению объема полученной ренты, это значит, что она оказывается эфрфективнее статусКво.

Применяются множество способов интернализации. Кроме спецификации первичных прав собственности с последующим обменом ими, можно выделить установление специальных налогов (субсидий - для позитивных внешних эффректов), количественных ограничений, интеграцию (вертикальную, горизонтальную, конгломератную), систему голосования по поводу приемлемого объема вредного действия или выбора соответствующих инструментов интернализации, смешанные формы институциональной реакции на внешние эффректы. Наконец, сохранение статус-кво и соответственно отклонение общественных и частных выгод (издержек) также могут рассматриваться как одна из возможных альтернатив.

Очевидно, что трансакция между двумя заинтересованной сторонами будет осуществляться тогда, когда расходы спецификации прав собственности и издержки обмена правами собственности равны нулю или достаточно малы в сравнении с взаимными выгодами от обмена. 


\section{РОЗДІЛ 3}

\section{ПРОЦЕСИ СТАНОВЛЕННЯ ЛЮДСЬКОГО КАПІТАЛУ В УМОВАХ ПЕРЕБУДОВИ ІНСТИТУЦІОНАЛЬНОГО СЕРЕДОВИЩА}

\section{1. Інституціональна природа людського капіталу}

Інституціональна сутність людського капіталу національної економіки безпосередньо залежить від сфрормованої інституціональної системи певної країни, іiї розвиненості. Ступінь розвитку людського капіталу національної економіки завжди віддзеркалює розвиток країни взагалі, тому і важливо провести кореляцію між інституціональним змістом людського капіталу та ступеню розвитку інституціональної системи країни.

Розвиток людського капіталу в умовах формування оновленої інституціональної системи викликає потребу у розгляді інституціональної природи людського капіталу національної економіки.

Людський капітал $є$ надійним підґрунтям, базою розвитку держави соціального, економічного, політичного. Саме від людського капіталу залежить позиція держави як на всіх видах світових ринків (політичному, економічному), так і рівень розвитку самої країни. Інноваційний вектор України спрямований на досягнення стабільних високих економічних показників шляхом використання людського капіталу і задля людського капіталу, для окремої конкретної людини [26]. Концепція «людського капіталу» в Україні розглянута під різними кутами різноманітних трактувань.

Інституціональна теорія стала базовою в вирішенні ряду питань національної економіки. В нинішніх умовах трансформації традиційних інститутів та інституцій, формування нової інституціональної держави стає актуальним дослідження інституціонального змісту людського капіталу.

Напрям класичного інституціоналізму був започаткований в працях Т. Веблена, розвинутий Дж. Коммонсом, У. Мітчелом, Дж. Гелбрейтом. Засновниками сучасної теорії інституціоналізму вважаються Р. Коуз, Д. Норт. 
Серед вітчизняних вчених ґрунтовно дослідженням різних аспектів інституціональної теорії займаються А. Гриценко, А. Ткач, А. Чухно, В. Якубенко. Вивченню людського капіталу присвятили свої роботи українські дослідники В. Антонюк, Д. Богиня, О. Брацлавська, В. Геєць, Л. Галабова, О. Грішнова, Ж. Дерій, Е. Лібанова, В. Мандибура, М. Семикіна, А. Чухно. Чорна, Л. Шаульська.

Багатогранність та постійний розвиток категорії, висока мобільність людського капіталу, його постійний рух, потяг до самовдосконалення, динамізм, а отже кардинальна зміна суттєвих параметрів людського капіталу вимагає нових досліджень і розробок.

Наряду 3 існуючими дослідженнями трансформування старої інституціональної системи і виникнення нових інституцій та інститутів потребують аналізу оновленого інституціонального змісту людського капіталу національної економіки.

Необхідність визначення інституціонального змісту людського капіталу перш за все викликана існуючими умовами формування нового людського капіталу України. Трансформація всієї інституціональної системи держави викликала зміну змісту всіх ії складових. Людський капітал при трактуванні його як фрактору економічного зростання національної економіки повинен перебувати в постійному розвитку. Але політична ситуація в країні викликала негативну динаміку показників, що традиційно визначають розвиток людського капіталу національної економіки.

Економічна ситуація в Україні неоднозначна. 3 одного боку зниження істотних умов функціонування людського капіталу національної економіки, про що наголошують провідні дослідники [24]. 3 другого боку, абсолютні економічні показники підвищуються. Так, за останні три роки (2014-2016) спостерігається зростання валового внутрішнього продукту на 49,6\% [35]. Але за період 2014-2017 роки падіння курсу гривни відносно долара відбулося у 3,3 рази (курс Національного банку України на 09.01.2014 року - 799,3 гривень за 100 доларів, на 02.10.2017 року - 2657,8 гривень за 100 доларів) [21]. 
Тому зростання валового внутрішнього продукту за цей період пояснюється основним чином зростанням цін, а не фізичних обсягів виробництва. Про це свідчить від'ємна динаміка індексів фізичного обсягу валового внутрішнього продукту (від 104,1 у 2010 році до 90,2 у 2015 році) [8] та зростання індексу споживчих цін (124,9 в 2014 році, 143,3 в 2015 році, 112,4 в 2016 році, 112,5 за січень - листопад 2017 року) [14]. Загальний індекс споживчих цін за період з 01.01.2014 року по 01.10.2017 року склав 221,7 .

Економічно активне населення України за шість років скоротилося на $16,1 \%$ - від 20,9 млн. осіб в 2010 році до 18,0 млн. осіб в 2016 році [8]. Дещо менший темп зниження зайнятого населення працездатного віку $1,122 \%$ [8]. Населення України на 01.01.2017 року Державна служба статистика визначає як 42,6 млн. осіб при тому, що на 01.01.2000 року задекларована кількість 49,4млн. осіб. Таким чином, спостерігається скорочення кількості платників податків.

Темп зростання середньомісячної заробітної плати з 01.01.2014 року по 01.01.2017 року склав 1,5 - з 3480,00 гривень в 2014році до 5183,00 гривень в 2016 році [35]. За офріційною статистикою, залишається стабільно високий рівень безробіття населення працездатного віку - 10,0\% у першому півріччі 2017 року [35].

Курс долара на 01.10.2017 року склав 2657,8 гривень за 100 доларів США (за курсом Національного банку України) [21]. В Державний бюджет України на 2018 рік закладено курс долара на рівні 3010,0 гривень за 100 доларів США [21].

Таким чином, економічні умови формування та функціонування людського капіталу зумовлені нестабільністю економічної ситуації в Україні, що викликана падінням валового внутрішнього продукту, зростанням цін у 2,2 рази при зростанні середньомісячної заробітної плати тільки в 1,5 рази, інфляцією, а також наявним військово-політичним протистоянням. Економіка України характеризується нестійкістю та невизначеністю.

Функціонування людського капіталу обмежено існуючими нормами, правилами, підпорядковується визначеним законодавчим актам, 
відбувається в рамках певних організацій і, таким чином, інституціонально обмежено.

Інституціональна система України визначається наступними складовими: тими, що залишилися від попередніх режимів; трансформованими складовими, імпортованими складовими.

В Україні в даний час відбувається зміна, трансформація одних інститутів в інші. Неефективні неформальні інститути витісняються легітимними нормами, що трансформує поведінку економічних суб'єктів. Це сприяє розширенню інституційного поля, досягненню однорідності інститутів, синхронності їх функціонування, інституціоналізації механізмів взаємодії бізнесу і держави [41].

Відбувається імпорт інститутів. За твердженням дослідників, довіра до імпортованих з розвинених країн ринкових інститутів низька [41]. Використання даних інститутів в Україні, яка має свої специфічні особливості, сприяє розвитку масштабної тіньової складової в економці України.

Нинішній розвиток суспільства характеризується невисоким рівнем поваги бізнесу до влади і неврахування владою економічного вкладу бізнесу в економіку країни. Одночасно швидко зміцнів базовий інститут приватної власності і зросла його роль в суспільстві.

Складові економічної системи України (крупний фінансовий капітал, бізнесові структури, тіньова економіка, державний сектор) взаємодіють між собою за принципово різними інституціональними засадами.

Рівень довіри суспільства до влади та держави як ефективних суспільних інститутів падає. В той же час поширюються нові для України неформальні інститути (професійні асоціації, громадські об'єднання, політичні партії).

Основний факт, що характеризує інституціональний розвиток нашої країни, є невизначеність меж інституціоналізації, що має на увазі нез'ясовані часовий і просторовий фактори, обмеженість чи необмеженість законодавчої бази, ступінь необхідної формалізації існуючих і майбутніх інститутів, обмеженість або вседозволеність їх взаємодії, змішаність 
господарських відносин і багато інших аспектів.

До суттєвих інституціональних умов фрункціонування людського капіталу відноситься також відсутність позитивного чи негативного досвіду існування, співіснування певних інститутів в певній економіці країни, який би дав підстави для аналізу та доцільності їх застосування.

Людський капітал є втіленням в індивідуумі здатності давати дохід, сумою здібностей, знань, кваліфікації та навичок окремого працівника. Як і фрізичний капітал, людський капітал здатний нагромаджуватися. Його потрібно амортизувати з урахуванням, що на певному життєвому етапі він припинить своє існування або цілком чи частково втратить власні якості (внаслідок смертності, дискваліфікації). Сектор освіти $€$ важливим елементом інституціональної системи, що продукує людський капітал у співвідношенні з визначеною продуктивністю, часткою часу освіти від загального обсягу часу кожного індивідуума й середнім рівнем людського капіталу, який є на даний момент. Людський капітал можливо визначити як узагальнення складників людського капіталу у виробничому секторі, людського капіталу у дослідницькому секторі, людського капіталу у секторі освіти.

Для інституціональної системи характерно поєднання та взаємозалежне функціонування всіх інститутів та інституцій. Формування людського капіталу національної економіки безпосередньо пов'язано 3 такими інститутами, як традиції та релігія, звичаї та виховання, сім'я та ідеологія, менталітет та культура, формальні закони та систем покарання, система та рівень освіти, професійна діяльність, мотивація. Опосередкований вплив на людський капітал надають такі базові економічні інститути як приватна власність, конкуренція, трансакційні витрати, контрактні відносини, ринок. В розвинених країнах визначальними інститутами, що формують людський капітал вважається сукупність соціальних інститутів - громадянське суспільство, національні інтереси, в які інтегруються базові економічні інститути.

Інституціональний зміст людського капіталу формується на даний час під впливом низки таких чинників, як міграція кваліфікованих трудових 
ресурсів, падіння рівня кваліфікації робочої сили, активне впровадження революційних технологій у виробничій сфері та сфрері послуг, прогнозована демографічна криза в країні, низький рівень фінансування освіти та системи охорони здоров'я, зниження тривалості життя в країні, падіння індексів освіти та рівня життя.

Задля розвитку і ефективного функціонування людського капіталу національної економіки, всі елементи та складові інституціональної системи повинні активно взаємодіяти. На необхідності активної взаємодії інститутів, механізмів реалізації правил і норм вказував Д. Норт [19]. Саме інтенсивність їх взаємодії пояснює революційний розвиток економік одних країн і затяжний поступовий шлях відсталих країн. Інерційність інституціональних характеристик гальмує будь-як зрушення в економіці країни, і, як наслідок, в розвитку інституціоналізації людського капіталу національної економіки.

У довгостроковому періоді економічне зростання прямо пропорційне розширенню інститутів і обернено пропорційне неформальній сфрері, тобто чим ефективніші формальні інститути і чим повніше задоволений попит суспільства на них, тим вище очікуване та прогнозоване економічне зростання [41].).

Людський капітал обмежений в своїх діях інституціональною структурою суспільства. Проблема - подолання, порушення цих інституціональних обмежень, що проявляється в опортунізмі.

Інституціональне середовище в інституціональній теорії розглядається як сукупність основоположних соціальних, політичних, юридичних і економічних правил, що визначають рамки людської поведінки [40]. За визначенням ця категорія пов'язана з людиною та обмежує рамки людської поведінки.

Інституціональне середовище людського капіталу національної економіки складають правила (етичні, моральні, соціальні, суспільні), норми (правові, законодавчо закріплені), інституції. Провідну роль в інституціональному середовищі людського капіталу завжди відігравали такі усталені інститути, як держава, система охорони здоров'я, система освіти, 
праці. Але не менш важливими складовими інституціонального середовища виступають неформальні інститути сім'ї, виховання, традицій, менталітет та культура, релігії. Задачі інституціонального середовища реалізуються через різноманітні інституціональні структури, інституції (організації)

Тісна взаємодія складових інституціонального середовища не тільки повинна відбуватися задля розвитку i ефективного функціонування людського капіталу національної економіки, але їі існування обумовлено природним існуванням інституціонального середовища. Інституціональне середовище по своїй природі є природним утворенням за прикладом сім'ї на відміну від штучного - наприклад, підприємства.

Для національної економіки країни інституціональний вплив проявляється в якості сфрормованого під дією певної інституціональної системи людського капіталу і його фрактичної можливості продукувати валовий продукт та ефективно (або неефективно) використовується 3 метою управління людським капіталом.

Вплив людського капіталу на середовище неоднозначний. Це зумовлено особливостями людського капіталу. Так як людського капіталу невід'ємний від людини і належить людині, він стає неповторним на особистісному рівні розгляду людського капіталу. На макро- та мегарівнях розгляду людський капітал також стає унікальним як сукупність носіїв капіталу з неповторними властивостями. Проте, наголосимо, що від'ємна риса людського капіталу - неможливість спадкоємності даного виду капіталу. Дослідники відзначають здатність людського капіталу до розвитку та накопичення [5]. Відмітимо, що за стадією накопичення неминуче настає стадія руйнування. За визначенням Д. Норта, інституціоналізація економіки (в цілому) - це процес становлення формальних інститутів, що обмежують поведінку економічних суб'єктів і .... угод, правил гри, стереотипів поведінки, традицій [19].

Основний фрактор на підставі якого ґрунтується людський капітал - це людина з її здібностями, навичками, вміннями. Непередбачуваність поведінки та дій людини, що пов'язані перш за все з ії психологією, 
викликає значні складнощі в процесі інституціоналізації людського капіталу. Тому фрормування нових та удосконалення існуючих інститутів, що стосуються людського капіталу, завжди викликає питання ефективності їх застосування. На думку деяких дослідників, лише при наявності відповідного комплексу інститутів виробничі можливості людини стають капіталом [11].

Під впливом інституціоналізації змінюється об'єкт впливу - людський капітал. В свою чергу, наслідком інституціоналізації стає зміна та нова якість самих інститутів, інституцій, їх взаємодій, зміна інституціонального середовища. Трансформація та заміна інституціонального середовища можлива еволюційним та революційними шляхами. Людський капітал в економічній системі виступає ініціативним суб'єктом, який безпосередньо може впливати на всі економічні, політичні, інституціональні процеси. Тому інституціоналізація середовища загрожує опортунізмом з боку людського капіталу, без якого, зазвичай, не обходяться будь-які зміни. Тому межі інституціоналізації, можливі позитивні чи негативні наслідки потребують ще глибинних досліджень, так як мова йде про найцінніший ресурс національної економіки України - людський капітал. Аналізу потребують ступінь розвитку інституціонального середовища та потреби в його подальшої інституціоналізації.

\section{2. Розвиток інституціональної системи людського капіталу}

Культивування інтегрального мислення в розумінні трансформації нової економіки визначає потребу перегляду існуючих теорій і практики розвитку людського капіталу. В такий теоретичний контекст, що запропонований в доповіді римського клубу [91], повністю вписується інституціональна парадигма людського капіталу.

Становлення сучасної концепції людського капіталу пов'язане 3 розвитком постіндустріального інфрормаційного суспільства, економіки знань, цифрової економіки, нейроекономіки. Економічний прогрес і суспільний розвиток залежать від інтелектуалізації життя населення [28]. А 
вкладення в людський капітал в період ринкового розвитку економіки вважаються новим інструментом для вимірювання соціально-економічного прогресу держави та потенціалу як благополучних країн, так і таких, що розвиваються [7; 31].

Більшість науковців розглядають розвиток людського капіталу в рамках методологічних традицій неокласики: пояснюють і оцінюють економічні та позаекономічні явища і процеси, зокрема, питання створення і використання людського капіталу на основі принципу максимізації поведінки індивідуумів. Разом з тим, зміни в характері розвитку економіки, переміщення більшості зайнятих з сфери виробництва у сфреру послуг, роботизація суттєво змінюють як теоретичні, так і практичні погляди на розвиток людського капіталу. Це потребує виходу за межі методологічного індивідуалізму неокласичного і інших подібних підходів в дослідженнях шляхів трансформації людського капіталу.

Головну роль в аналізі змісту і ролі людського капіталу в сучасній економіці може відіграти нова інституціональна економічна теорія. Спираючись на досягнення цієї теорії вірогідно визначити зміст інституціональної парадигми розвитку людського капіталу в часи нової епохи «Відродження».

Формулювання гіпотези і обґрунтування перспектив розвитку інституціональної парадигми людського капіталу як інтелектуальної складової нової економіки ґрунтується на основі аналізу історичного розвитку змісту людського капіталу.

В рамках існуючої методології сучасна концепція розвитку людського капіталу виходить 3 того, що первинною господарською одиницею визнається домогосподарство, а не окремий індивід. Вона дала імпульс розвитку теорії економіки сім'ї: домашнє господарство і споживча діяльність стали виділятися в особливий вид виробництва. В будь-якому випадку розвиток людського капіталу зводиться, а іноді просто ототожнюється 3 відтворенням робочої сили. 3 погляду класичної економічної науки, відтворення робочої сили - лише чинник виробництва. В існуючих теоріях немає гідного місця для сучасного розуміння сутності людського капіталу, 
як мети і змісту будь-якої суспільної діяльності. Зміст поняття зводиться до того, що це запас природних або набутих внаслідок інвестування здібностей, навичок, досвіду, знань, інформаційної культури, мотивації та мобільності індивіда, використання яких в економічній діяльності дає йому вищі прибутки всім користувачам.

Одним з стимулюючих інститутів формування людського капіталу $є$ правові та позасудові норми, що визначають і захищають права власності людини.

Іншою умовою розвитку людського капіталу $\epsilon$ наявність безлічі пов'язаних інститутів. Наприклад, таких як франшиза, тобто, набір благ, який складається з прав користування брендом, методів ведення бізнесу, товарного знаку, технологій, наданих за плату та на основі взаємних зобов'язань і оформлених відповідно до закону про охорону інтелектуальної власності.

Це зумовлює потребу в людському капіталі з новітніми знаннями, навичками, вміннями, тобто з більш високою конкурентоспроможністю, що, в свою чергу, висуває нові вимоги до такої складової людського капіталу, як освіта [42]. Оптимальні інвестиції в людський капітал залежать від різних чинників, таких як стан середовища, в якому функціонують ринок капіталу, рівень стабільності в економіці, політиці. Коли політична влада знаходиться в нестійкому положенні, накопичення людського капіталу, ймовірно, не буде оптимальним, оскільки учасники не можуть взяти на себе довгострокові зобов'язання перед суспільством, яке заслуговує на довіру.

Якщо запорукою економічного успіху $є$ ефективні інститути [9, с. 7], то чому на цій основі не отримав достатнього розвитку весь світ, а тільки його частина?

Д. Аджемоглу, С. Джонсон, Дж. Робинсон виявили витоки зростання людського капіталу, які залежать від запровадження інститутів в колонізованих частинах світу [1]. Коли європейці прибули на території, що мали високу щільність населення в існуючих популяціях і багаті ресурси, це загальмувало розвиток цих популяцій. Причина: там були використані неефективні інститути, які дозволяли європейцям оподатковувати і 
витягувати орендну плату з населення. В той же час, території з меншою щільністю населення і більш бідні підпали під дію тих інститутів, які здатні були стимулювати європейську міграцію. Ці інституціональні відмінності зберігалися і призводили до зміни існуючого стану. Наслідком розширення влади англійців, які заселили більшу частину Північної Америки, а також оселилися в деяких частинах Карибського басейну став той фракт, що бідніші території, такі як Північна Америка, стали багатшими, а багатші місця, наприклад Карибський басейн, застигли в своєму розвитку.

Європейські держави привнесли неефективні інститути в одні місця і започаткували ефективні в інших. Це стосується інститутів, пов'язаних 3 майновими правами людини, навчальних закладів і франшиз.

Історично склався цілий ряд інститутів праці і людського капіталу. В їх розвитку спостерігаються такі найменш вільні, як рабство та підневільний стан, трудові договори різних типів, включаючи учнівство, i, в кінцевому рахунку, безкоштовна робоча сила з відповідними навчальними закладами.

Продукування людського капіталу передбачає збереження і передачу знань, які забезпечують умови для економічного зростання. Але така передача не могла бути широкою та охоплювати великі маси людей, поки не з'явилися спеціальні інституції у вигляді шкіл.

Знання передавалися та продовжують передаватися і без формальної шкільної системи. Сократ вчив Платона, Платон Аристотеля, приватні репетитори викладали конфуціанську класику сотням тисяч китайців, щоб вони мали змогу участь в екзаменаційній системі оцінювання знань, підмайстри навчалися навичкам у своїх майстрів; батьки завжди вчили своїх дітей. Але тільки в школах, де навчання людини починається змалечку, отримання знань охоплює широке коло пересічних людей та набуває системного характеру.

Перехід до масової початкової освіти в більшій частині Європи почався орієнтовно в кінці дев'ятнадцятого сторіччя, але в Північній Америці стався набагато раніше. У Сполучених Штатах і Пруссії, провідних країнах в галузі освіти, рівень початкової освіти до 1860 року становив близько 70 відсотків кількості дітей у віці від 5 до 14 років [64]. 
Сполучені Штати зберегли своє лідерство і випередили Німеччину в кінці дев'ятнадцятого сторіччя. Коефіцієнт початкової освіти перевищив 90 відсотків. У Франції, Німеччині та Великобританії до початку двадцятого століття рівень початкової освіти перевищив 70 відсотків.

Показники основних змін в освіті в Європі і Сполучених Штатах з 1840 по 1940 рік треба використовувати з певною обережністю. Шкільні дані часто отримують з загальних переписів населення, не враховують кількість місяців, протягом яких діти відвідують школу. Особливо, коли дані по школам базуються на адміністративних записах. У багатьох місцях, де ще не існує середніх шкіл, старша молодь відвідує загальні або початкові школи, в яких проводять навчання початкові класи. Тому чисельність може бути завищена дітьми старшого віку. Ще одна складність полягає в тому, що при зіставленні між країнами необхідно враховувати різні інституційні особливості країн, оскільки школи майже завжди є частиною державного сектору.

Освітнє лідерство Сполучених Штатів в дев'ятнадцятому столітті продовжило значне зростання в двадцятому з початком «руху середньої школи». Більшість багатих країн Європи до початку двадцятого століття мали широку початкову освіту, але масова освіта на рівні середньої школи і вищої освіти була відсутня.

Сполучені Штати істотно збільшили чисельність молоді, яка закінчила середню школу. На відміну від них, статистичні дані по 13 країнам, наведені Організацією економічного співробітництва і розвитку, показують, що в середині 1950-х років показники зарахування в середні школи підлітків в очних загальноосвітніх школах були низькими у всій Європі. Багато країн Північної Європи мали технічні програми для підлітків. Але навіть з їх урахуванням чисельність учнів мала, що не відповідає широкому розповсюдженню системи середньої освіти і, таким чином, не є підставою для поширення системи вищої освіти [62].

Та, в кінцевому рахунку, Європа увійшла разом зі Сполученими Штатами, в перелік країн з масовою освітою. А в останні десятиліття, випереджала їх з точки зору як кількості так і якості середньої освіти. 
Двадцяте століття стало століттям людського капіталу. Освіта в Сполучених Штатах, як правило, мала відкритий і поблажливий характер. Відкритість позиціонується як допуск до навчання в школах всіх дітей. Відкритість американських шкіл пов'язана з тим фрактом, що починаючи 3 середини XIX століття початкові і середні школи повністю публічно фінансувалися місцевими та державними органами влади. Поблажливість в школах визначається тим, що учням, які погано навчаються, як правило, дозволяється переходити до наступного класу. Поблажливий характер пов'язаний з низьким рівнем існування до недавнього часу малої кількості стандартизованих тестів, затверджених на законодавчому рівні.

Характерною рисою освіти в США було те, що вона не тільки академічна, але й мала також практичне спрямування. При цьому ще й всім дітям надається можливість перейти на більш високий рівень, навіть якщо фінансові обмеження перешкоджають досягненню цієї мети.

Дискусії про рівні освіти не вирішили ґрунтовного питання в застосуванні людського капіталу. Постало питання доцільності інвестування в освіту або навчання. Проста модель інвестицій в людський капітал свідчить про те, що інвестиції більш вірогідні, коли прибутковість вища, а витрати нижчі (можливо, нижчі з економією від масштабу, що надається школами), а ставка дисконтування (можливо, функція батьківського доходу і більшої визначеності) нижча. Але проста модель не враховує кілька важливих фракторів, таких як місце проведення навчання (школа, робота вдома); суб'єкти, які забезпечують навчання і оплачують його; роль держави або колективів у даних питаннях.

У тих випадках, коли технологічні зміни носять швидкий характер і географічна мобільність висока, в цілому, гнучка освіта є більш цінною, ніж специфічна освіта для конкретної професії або місця, яка є відносно негнучкою. Коли ситуація складається навпаки, конкретна підготовка набагато краща. Америка мала значну географічну мобільність і протягом деякого часу більшу технологічну динаміку, ніж Європа. Обидва ці чинники зробили гнучку освіту більш цінною, а професійне і промислове навчання менш цінними та привабливими. 
Майже у всіх країнах і протягом більшості історичних періодів освіта надавалася державою і нею фінансувалася. Були випадки, коли приватний сектор був значнішим, але державна частка майже завжди поступово збільшувалася.

Причин для зростання участі уряду в освіті достатньо. Держава має різноманітні інтереси в сфрері освіти, які підвищують попит на школи i, в свою чергу, примушують державу до субсидування освіти. Основний інтерес держави полягає в тому, що освіта забезпечує основу для створення суспільних благ, у тому числі наділяє громадян сукупністю загальних цінностей. Держава також зацікавлена у виправленні ринкових збоїв в сфері шкільної освіти.

Демократичні держави вимагають грамотних громадян і освічених лідерів; недемократичні уряди часто обмежують освіту. В державах існує нескінченна потреба в освічених особах, включаючи вчителів, інженерів, військовий персонал, духовний персонал і бюрократів. Освіта створює позитивні зовнішні фактори багатьох типів, такі як зниження рівня злочинності та поліпшення здоров'я. У місцях з низькою щільністю населення школи часто $€$ природними монополіями, а їх державне забезпечення та регулювання виправдано міркуваннями збільшення кількості освіченого населення, і за рахунок цього зниження ціни навчання.

ще одна причина участі держави в освіті полягає в тому, що держава змушена контролювати процес залучення дітей до навчання. Особливо це стосується випадків, коли батьки не усвідомлюють важливість та необхідність навчання, або діти занадто короткозорі.

Закони про обов'язкове шкільне навчання і дитячу працю часто допомагають досягненню цих цілей. Ці закони є обов'язковими в таких країнах, таких як Великобританія та Ірландія, де держава фрінансує школи i платить вчителям за високоякісну широку освіту.

Оскільки освіта не є чистим суспільним благом і може бути придбана у приватному секторі, батьки можуть відмовитися від державної системи, навіть якщо вони платять податки, з яких фінансується освіта. Батьки 3 низьким попитом на освіту (або низьким доходом) не будуть голосувати за 
високі витрати, а батьки з високим попитом на освіту (або високим доходом) також не здатні голосувати за високі витрати, оскільки, швидше за все, вони відмовляться від державної освіти і скористуються приватним освітнім сектором. Одне з рішень полягає в тому, щоб мати невеликі округи, які будуть краще відповідати шкільним витратам, батьківським вимогам і нададуть більш високий рівень шкільної освіти. Одним з значних досягнень освіти в США було створення великого числа невеликих, фінансово незалежних округів.. Сьогодні налічується близько 16000 в основному незалежних шкільних округів [62].

Освіта більшості країн просунулося до масовості через три реформи, які стосуються трьох частин шкільної освіти: початкової, середньої та вищої. Точне число тривалості кожної з цих частин і вік, в якому молодь робить кожен з переходів, не однакові між країнами. Однак існує значна одноманітність, ймовірно, пов'язана з біологією розвитку дитини.

Нові технології підвищують попит на кращі навички. Технології кінця дев'ятнадцятого і початку двадцятого століть збільшили попит на робітників, які могли читати креслення, знали небагато про електрику, були досить грамотними для того, щоб друкувати з книжок і на швидку руку диктували листи. Технічний прогрес протягом усього минулого століття збільшив попит на ще більше розвинутий людський капітал.

Значне збільшення темпів повернення до освіти та профресійної підготовки в Сполучених Штатах протягом останніх декількох десятиліть відбулося головним чином тому, що пропозиція людського капіталу не зросла в достатній мірі і попит на навички прискорився. Але, останнім часом пропозицію людського капіталу знову почала збільшуватися.

Людський капітал, втілений в робочій силі, зростає, але сильно змінився за змістом, а вимоги до навичок в економіці знань посилилися. Переваги освіти сприяли поширенню людського капіталу з точки зору тривалості освіти. Однак в останні десятиліття ці характеристики, можливо, сповільнили прогрес, особливо з точки зору якості освіти. Фінансована державою освіта в невеликих, фінансово незалежних округах збільшувала тривалість навчання, але призвела до великих відмінностей в знаннях 
учнів. Відкрита і поблажлива система сприяла поширенню освіти в маси, але вона часто мала недостатньо стандартів просування і випуску навіть на державному рівні. Багато з цих недоліків первинних чеснот в даний час переглядаються державами.

Тема людського капіталу за своєю суттю є історичною. Дослідження історії шкільної освіти в усьому світі, особливо за межами Європи і Північної Америки, все ще знаходиться в зародковому стані. Перелік питань і тем у вивченні людського капіталу та його еволюційної історії довгий.

Залишається багато питань, що мають бути історично досліджені. Чому уряди розширюють формальну шкільну освіту і чому неформальна підготовка має більш важливе значення в певних місцях і в певні періоди? Який взаємозв'язок між потребами нижнього рівня шкільного навчання i забезпеченням вищої освіти? Яка взаємодія між освітою і охороною здоров'я, якщо звісно, що в даний час більш освічені люди мають краще здоров'я?

Формування інституціональної парадигми розвитку людського капіталу пов'язане з розвитком постіндустріального суспільства і економіки знань. Тому дану концепцію можна віднести до нової економіки, розвиток якої здійснюється за умови, що найманий працівник уже не завжди відчужується від відносин власності: він сам стає власником «нових» економічних ресурсів - знань, кваліфікації, досвіду, інформації. Концепцію людського капіталу можна розглядати в рамках методологічних традицій неокласики: пояснювати і оцінювати економічні і позаекономічні явища i процеси, зокрема питання створення і використання людського капіталу на основі принципу максимізації поведінки індивідуумів.

Однак, в рамках даної концепції, первинною господарською одиницею визнавалося домогосподарство, а не окремий індивід. Тому невипадково вона дала імпульс розвитку теорії економіки сім'ї: домашнє господарство і споживча діяльність стали виділятися в особливий вид виробництва. Близько $30 \%$ часу найманих працівників припадає на традиційний робочий час, інші $70 \%$ - витрачаються в сфері дозвілля i 
споживання. У розрахунку по населенню в цілому 15\% всього громадського часу відводиться на традиційний робочий час, решта часу витрачається на відтворення робочої сили. Дану сферу можна також позначити сферою соціального відтворення, аналіз якої знайшов своє відображення в рамках сучасної економічної соціології.

Визначальним фрактором постіндустріального суспільства, а отже, основним елементом фрормування людського капіталу на новому етапі розвитку економіки визнаються знання, вміння, інформація. У науці, це призвело до появи нового напряму - економіки знань [38].

Про масштаби економіки знань в розвинених країнах свідчить ряд показників. У США в складі сфрери послуг (частка якої у виробництві валового національного продукту США з 60-х років зросла з 50\% до більш ніж 72\%) 63\% послуг можуть бути віднесені до категорії інтелектуальних, основою яких є поширення і використання інформації [37].

Інвестиції в людський капітал в США в 90-і роки втричі перевищили інвестиції у фрізичний капітал, витрати на освіту перевищили половину інвестицій у фрізичний капітал, витрати на охорону здоров'я виявилися ще вищими.

Частка інвестицій в людський капітал в загальному обсязі ВНП США, за деякими оцінками, становить понад 15\% ВВП, що перевищило чисті валові інвестиції приватного капіталу у виробництво.

Коефіцієнт ефективності людського капіталу в світі в 2016-му році становив 0,3, в США - 1,2. Індекс якості людського капіталу в США складав 1,67, а в Росії - 0,31 [16].

Перехід до нової, постіндустріальної економіки характеризується найважливішою довгостроковою тенденцією - прогресом знань і нарощуванням складності соціально-економічного життя, створений потужними факторами інформаційних і комп'ютерних технологій і веде до розширення глобального економічного простору. Зростаюча складність породжує різноманітні соціально-економічні, політичні та технологічні проблеми, які посилюють суперечливість інституційного розвитку людського капіталу. 


\section{3. Інституціональна структура людського капіталу}

Людський капітал $€$ надійним підґрунтям, базою розвитку національної економіки - соціальної, економічної, політичної. Саме від людського капіталу залежить позиція держави як на всіх видах світових ринків (політичному, економічному), так і рівень розвитку самої країни [63]. Економічний прогрес і суспільний розвиток залежать від інтелектуалізації життя населення [28].

Концепція людського капіталу вже давно використовується але значення категорії взагалі неоднозначне або добре розуміється. Також залишаються невизначеними складники людського капіталу, його компоненти, базові складові, на яких ґрунтується людський капітал, завдяки яким він може зростати та розвиватися. Виокремлення базових компонент формування людського капіталу вважаємо стратегічним підґрунтям для розвитку людського капіталу та, в свою чергу, підставою для визначення основних напрямів інвестицій в людський капітал.

Визначення компонент людського капіталу національної економіки необхідні для розробки основних напрямів інвестицій в людський капітал.

Зміна економічної ситуації в Україні стає все більш невизначеною, і реструктуризація структур всіх секторів національної економіки матиме значний вплив на сегмент праці в цілому. Зрозуміло, що в майбутньому в даному сегменті на всіх рівнях (індивідуальному, колективному, національному) буде використовуватися певний людський капітал та вестися пошуки додаткового людського капіталу. Незважаючи на те, що в останній час підкреслюється важливість людського капіталу, виникли нові проблеми в структурі економічного та практиці трудового життя. Нові компоненти та складові людського капіталу здійснюють новітній специфічний вплив на його використання та потребують досліджень.

Людський капітал трактується як сукупність знань, вмінь, досвіду, навичок, освіти. Якість, кількість та ступінь компетенції людського капіталу, пояснюють різну здатність їх користувачів використовувати матеріальні ресурси, такі як гроші, технології та виробниче обладнання. 
Більшість з описаних вище характеристик людського капіталу вивчалися з метою розвитку знань, новаторських здібностей, навичок, освіти задля досягнення успіху в бізнесі, окремої особистості, країни. Проте в швидко мінливому діловому середовищі інформація швидко застаріває, підкреслюючи необхідність постійного розвитку, кар'єрного зростання, нового навчання. Значення розвитку персональних поглядів та розумових здібностей може бути оцінено та посилено в майбутньому по-новому, що також слід враховувати при організації та управлінні людським капіталом [83. Людський капітал виступає реальною можливістю досягнення успіху.

Який людський капітал має важливе значення для організаційної конкурентоспроможності, визначається стратегією організації та, з іншого боку, через ринок [73]. Теорія, що базується на ресурсах, визначає, що людський капітал породжує найважливіші конкурентні переваги, які майже неможливо копіювати, змінити або замінити іншим людським капіталом. Деякі дослідники на відміну стверджують, що людський капітал не обов'язково гарантує успіх і не $є$ таким критичним у всіх ситуаціях або у всіх сферах діяльності. Розвиток людського капіталу може не відразу з'являтися в результаті вкладень в нього, можливо, навіть навпаки. Це може бути пов'язано з тим, що дослідження рідко бувають достатньо тривалими, щоб перевірити переваги розвитку людського капіталу в цілому у повному обсязі.

Останніми десятиріччями спостерігаються зростаючі темпи політичних, економічних, соціальних і технологічних змін, що створює ряд економічних та технологічних проблем в глобальних та національних масштабах. Зменшуючи ефективність, такі застарілі джерела конкурентних переваг як дешева земля і природні ресурси, низькі витрати на екологію спонукають до пошуку нових джерел підвищення конкурентоспроможності національної економіки. Тривалий час вирішальним фактором виробництва була земля, пізніше - капітал. Тепер вирішальним фактором становиться людина, працівники підприємства 3 їх знаннями, навичками, компетенціями, вміннями, талантами - так званий людський капітал тощо. Проблематика людського капіталу займає ключове місце в сучасній економічній думці. 
Ще Адам Сміт стверджував, що освіта і навчання мають бути визнані як інвестиції у співробітників. Він також вважав, що продуктивність праці робітників, які мають певні навички, більш висока, ніж у працівників без таких навичок. А. Маршалл взагалі стверджував, що найціннішим з усіх видів капіталів є той, що вкладений у людей [26], тобто людський капітал.

В період переваги фізичної праці в термінології використовувалася робоча сила, однак пізніше зміст категорії змінюється. Іїі називають людським капіталом або часто, як синонім, застосовують поняття «людські ресурси». Незалежно від того, яке використовується поняття - «людський капітал», «людські ресурси» або «компетентність людини», мається на увазі переважно одне і те ж саме - використання і розвиток 3 метою досягнення користі як для конкретного роботодавця, так і в цілому для національної економіки. Головним аргументом, що доводить слушність розвитку дослідженнь людського капіталу $€$ теза, що саме людина з ї̈ інтелектуальним потенціалом найбільш цінний елемент серед економічних ресурсів. 3 цієї точки зору, людський капітал став предметом пильної уваги теоретиків і практиків.

Економічна наука протягом багатьох десятиліть приділяла пильну увагу виявленню ролі людського капіталу у забезпечені ефективного функціонування економічної системи. Компетенції, через які визначали людський капітал, охоплюють, здебільшого, природний талант і здатності, освіта і знання, практичний досвід і навички, стан здоров'я і психофізичний стан, позитивні риси характеру та якості людини як особистості, що являє собою специфічний капітал. Такий підхід узгоджується з тим положенням, що роботодавців цікавить, перш за все, компетентність працівників, завдяки якій вони можуть приносити користь та задовільняти економічні інтереси.

Аналіз ринкових процесів в сучасних системах дають підстави стверджувати, що економічна доцільність все меншою мірою вирішується за рахунок ресурсів, певних фрінансових чи матеріальних фракторів. Вирішальне значення починає набувати здатність використовувати нематеріальні ресурси, тобто наявний людський (соціальний, 
інтелектуальний) капітал. Все частіше і частіше в науковій літературі зазначається, що людина в компанії - це капітал і його слід розглядати в якості інвестиції, що гарантує найвищу прибутковість. Тобто саме людський капітал становить приховане джерело конкурентної переваги.

Формування теорій людського капіталу пов'язують з працями І. Фішера, але в деяких трудах можна прослідити і більш ранні дослідження людського капіталу. В працях В. Петті, Д. Ніколсона [77] та інших вчених було виділено ту частину капіталу, яка на відміну від землі, будівель, машин міститься в людях. Вони підкреслювали, що в XVIII столітті «живий» капітал широко розглядався у всіх спробах оцінки багатства певного народу. Це створило передумови виникнення теорій дослідження виробничих сил людини у вигляді людського капіталу.

Неокласична теорія людського капіталу остаточно сформувалася в 1950-1980-і роки. У цей період авторами найвагоміших досліджень поняття людського капіталу вважаються Г. Беккер, Д. Мінцер і Т. Шульц [54, 76, 84] (50-70 роки XX століття), що стали засновниками ґрунтовної теорії людського капіталу. Якщо розглядати теорію людського капіталу в контексті концепції ендогенного росту, то поняття людського капіталу пов'язують 3 такими іменами як Р. Лукас, П. Ромер, Р. Солоу. В своїх теоріях вчені істотним чином змінили погляд на людину. Поняття людського капіталу пов'язують із людиною зі своїми здібностями, кваліфікаціями, мотивацією і здоров'ям, що сприймається як основне джерело успіху як підприємства зокрема, так і всієї економіки у цілому. Таким чином, широко поняття людського капіталу почали застосовувати в економічній теорії лише в другій половині XX століття. Так наприклад, Т. Шульц у 1981 році свою концепцію людського капіталу пояснив наступним чином: «кожна людина володіє певними здібностями, які можуть бути вродженими або набутими. Набуті здібності людини, які мають значення і можуть бути збагачені за допомогою відповідного інвестування, ми будемо вважати за людський капітал» [86].

У 1999 році Н. Бонтіс, Н. Драгонетті, К. Джакобсен, Г. Рус запропонували більш докладне визначення: «Людський капітал являє 
собою людський фактор в організації; колективний інтелект, навички і знання, які придають організації її унікальний характер. Людським фрактором в організації є здатності до навчання, до інноваційного розвитку, оновлення та творчої спрямованості, і які, якщо їх належно мотивувати, можуть забезпечити довгострокове виживання організації» [55].

Багато хто з авторів стверджують, що людський капітал значною мірою існує у вигляді досить нестандартної форми, присутній неявно в голові людини. Він є динамічним і залежить від контексту і умов, в яких знаходиться людина. Такі характеристики людського капіталу ускладнюють визначення, вимірювання та оцінку людського капіталу. Особливості людського капіталу настільки важливі, наскільки важлива організаційна ефективність - це гнучкість і творчий потенціал працівників, їх здатність отримувати та розвивати знання та навички з часом і мотивувати відповідь на виклики в різних контекстах. Важливою складовою компонентою людського капіталу $є$ соціальний капітал. Р. Путам у 1996 році вперше визначив соціальний капітал як «характеристику соціального життя співтовариства, норми і довіри, що дозволяють людям діяти спільно більш ефективно для досягнення загальних цілей» [80].

Огляд сучасних інтерпретацій поняття людського капіталу вказує на різноманітність підходів до цієї категорії. В економічній літературі у визначенні людського капіталу переважає визначення терміну як набір особливостей демографічних груп характеристик (структура, вік, стан здоров'я) та навичок окремих людей [55]. Окрім того, у процесі формування людського капіталу відзначається також визначальна роль знаннь, здібностей, здоров'я людей. Його основою $є$ генетичні особливості людини. Його поліпшення можливе шляхом інвестицій, так званих інвестицій в людину. Безліч опублікованих визначень поняття «людський капітал» має характер розпливчатий і неоднозначний. Також вони змінюються разом 3 контекстом культури, пануючої моди, парадигмами, метафорами, звичаями і мовними практиками відповідного автора.

Згідно з дослідженнями, проведеними шведською страховою компанією «Скандія», людський капітал поєднує знання, навички, 
інноваційність і здатності окремих співробітників для ефективного виконання завдань [59]. Також до змісту поняття включаються корпоративні цінності, організаційна культура і фрілософія організації. 3 цієї точки зору, людський капітал являє собою комплементарну частину загального капіталу підприємства, що $є$ ефективними чинниками для визначення конкурентних переваг підприємства [57]. У такому разі важливими $\epsilon$ вартість, унікальність, стабільність людського капіталу, і який сприймається як істотне джерело ефективності підприємства.

Людський капітал не може бути власністю компанії, тому що він завжди супроводжує людину. Людський капітал вважається тривимірним і включає в себе: компетентність у застосуванні знань і вмінь, мотивацію до використання знань і умінь, інтелектуальні можливості, які розглядаються як здатність трансферу знань між різними сорерами, як потенційну ефективність, інноваційність, що служать для поліпшення знань і вдосконалення підприємства, тобто можливістю використання і розширення знань і навичок у практичній діяльності [55].

У польській науковій літературі людський капітал - це активи підприємств, що належать його працівникам і визначаються наступним чином:

- витрати підприємства на навчання і розвиток умінь своїх членів [83];

- є джерела знання, що у своєму прикритому вигляді виступають як інновації, і таким чином прямо сприяє економічному розвитку [58];

- особисті і соціальні навички, здатність до накопичення досвіду, знання, отримані в процесі навчання, а також будь-які інші навички, спрямовані на поліпшення взаємодії будь-якої організації з її клієнтами та іншими зацікавленими сторонами [74];

- своєрідний комплекс індивідуальних особливостей членів організації, у вигляді фрізичних, психічних, інтелектуальних і моральних складових, що формуються через схильності, таланти, знання, навички, компетенції, внутрішню мотивацію до професійної відповідності, ресурс здоров'я або життєвої енергії, та забезпечують функціонування і розвиток членів організації [80]. 
Аналіз сучасних аспектів, пов'язаних 3 людським капіталом, дає підстави вважати, що людським капіталом підприємства також можемо називати людей творчих спеціальностей 3 широкими кваліфікаціями, пов'язаних з організацією і її місією, які вміють спільно працювати [82]. У контексті цього визначення, людський капітал $є$ рушійною силою розвитку організації, що містить у собі величезні мотиваційні можливості. Вони розкриваються тільки тоді, коли здійснюється ефективне управління, 3 урахуванням місії та стратегічних цілей [70].

При визначенні та реалізації стратегії підприємства людський капітал, здебільшого, формується у двох напрямах. По-перше, як стратегічний капітал, що забезпечує, конкурентну перевагу протягом досить тривалого часу; по-друге, як операційний капітал, необхідний для втілення поточних завдань [90].

Крім інших складових, людський капітал також ґрунтується на зосередженні уваги на потребах клієнтів, на навичках ретельного аналізу виробничих процесів, на здатності до розвитку та впровадженні інновацій [81]. Людський капітал уособлений в людях, які пов'язані з суспільною працею на підґрунті особистих особливих фрізичних, психічних, моральних знань і навичок. Разом з тим, людський капітал включає інтелектуальний капітал, який виступає у віртуальному вигляді, складному для копіювання іншими людьми. Істотною проблемою при цьому виступає взаємозв'язок людського капіталу та організації, особливо тоді, коли працівники пов'язані з підприємством на вільних засадах і партнерськими відносинами. Тут виникає певний парадокс, адже те, на чому компанія має будувати свою конкурентну перевагу не є її власністю.

Міжнародні організації, які займаються вимірюванням і порівнянням на міжнародному рівні накопиченнями людського капіталу, визначають його як «навички, компетенції, знання, які втілені в людині, і які необхідні підприємству в економічній діяльності» [68].

У ряді досліджень, представлених у науковій літературі, найбільш важливими джерелами цінностей для економіки визначений людський капітал, який становить порядку $47 \%$ в структурі. Далі йдуть капітал 
відносин (27,3\%), фрінансовий капітал $(11,7 \%)$, інтелектуальна власність (8,8\%), унікальні виробничі процеси (продукти) (4,1\%) та інші джерела $(1,1 \%)$ (рис. 1) [59; 60; 74].

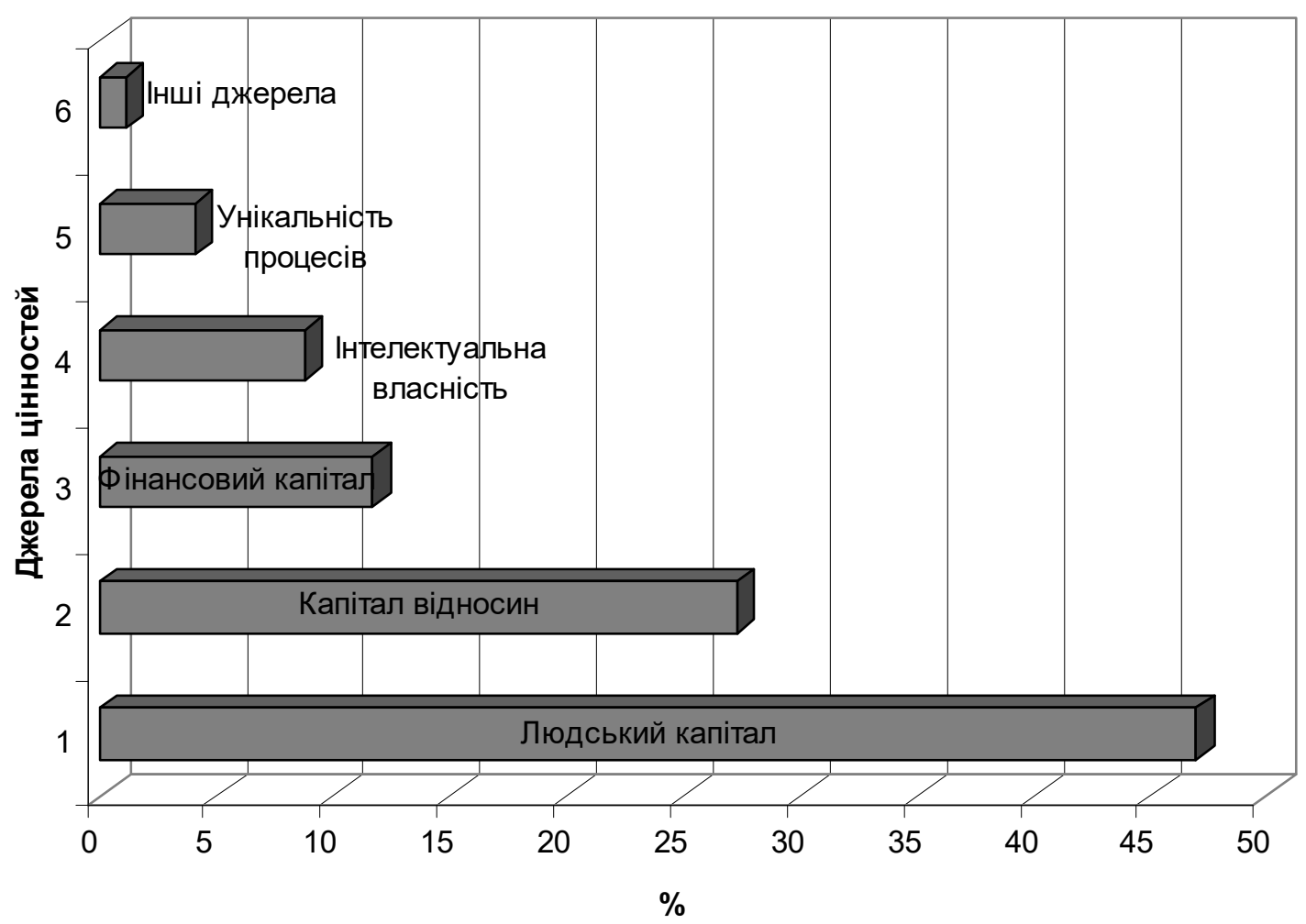

Рис. 3.1. Найбільш важливі джерела цінностей для економіки, \%

Привертає увагу якісний аспект людського чинника, оскільки якісне харчування і здоров'я окремих співробітників впливає на зростання виробничих можливостей співробітників. Саме з цієї причини інвестування в людський капітал пов'язані з витратами на охорону здоров'я [53].

В період бурхливого розвитку техніки починаючи з XVIII до початку XX ст. відбулося зародження нового підходу до трактування людського капіталу, який можна назвати особистісно-суб'єктним. Він поєднує його економічний зміст з фрізичним наповненням. Згідно цьому підходу, людина розглядається разом із ії знаннями, навичками, компетенціями, що дає підстави приділити достатню увагу в економічній науковій літературі управлінню людським капіталом в контексті його складових. 3 цієї точки зору, для якості людського капіталу особливе значення мають такі 
складові, як ясність розуму працівників, частота дій і здатність своєчасного реагування, успіхи людини в галузі, цілковита віддача в інтересах справи, найліпше використання соціального потенціалу, демонстрація нових ідей, прагнення співробітників до виконання завдань на високому рівні.

Але переважно це стосується управління компетенціями людського капіталу. Це стало причиною для динамічного розвитку напряму управління компетенціями, який поширився з вступом у нове тисячоліття.

Концепція управління компетенціями людського капіталу була сорормульована на початку сімдесятих років $\mathrm{XX}$ століття, коли один із класиків політекономії Д. Макклеланд наголосив на тому, що найкращим предиктором успіху кандидата на роботу є його компетенції і здібності [75]. При цьому автор запропонував розглядати людину як частину національного капіталу. І це докорінно відрізнялося від колишнього підходу до визначення цінності людини, який полягав у вимірювання інтелекту та знань людини за допомогою психометричних тестів.

Найбільш поширеними науковими трактуваннями людського капіталу $\epsilon$ визначення його з позицій формування і реалізації виробничих здатностей. Людина одночасно $€$ і виробником і споживачем продукції, організатором економічного життя, творцем реальності і споживачем. Така методологічна установка по своїй сутності, визначає людину не тільки як ресурс, що дозволяє збільшувати економічний капітал, але також представляє цінність людини самої по собі.

У 2000 році Світовий банк запропонував людський капітал визначати як складову соціального капіталу [69]. До соціального капіталу було віднесено інститути, відносини і норми, які фрормують якість і кількість соціальної взаємодії в суспільстві. «Соціальний капітал є не просто сумою інститутів, які є основою суспільства, - це клей, який утримує їх разом» [69]. Соціальний капітал складається з отриманих знань і проявляється в мережі взаємозв'язків власне самої організації, а також за її межами. Як бачимо, грунтовні підходи до визначення соціального капіталу і людського капіталу співпадають по своїх основних позиціях. Окрім того, визнається, що управління знаннями і використання знань займають центральне місце в 
новій економіці, заснованої на фундаментально нових організаційних і технологічних умовах [69]. Суб'єкт людського капіталу в економіці виступає як персоніфікація безпосередньої праці та інтелектуальної діяльності.

Спільним в зарубіжній науковій літературі $\epsilon$ те, що багато авторів дотримуються думки, що людським капіталом володіють люди, тому саме вони самостійно вирішують, коли, як і де саме цей капітал буде застосований, і в який спосіб сприятиме досягненню поставленої мети. Люди приймають рішення про те, якою мірою вони можуть бути готові залучатись до виконання своїх ролей в організації, економіці, національній економіці (підходи та ставлення до способу виконання роботи та прикладання зусиль, здатність до інноваційної та продуктивної поведінки). Статистичні дослідження доводять, що людський капітал в значній мірі сприяє досягненню успіху організації, а погане управління ним викликає невдачі. Поняття людського капіталу в економічному сенсі пов'язане 3 місцем людини в економічній дійсності.

Визначення компонент людського капіталу національної економіки зумовлено необхідністю розвитку людського капіталу. Розвиток завжди пов'язаний з значними витратами, у тому числі капітальними. Здійснення інвестицій доцільно здійснювати цілеспрямовано по окремим компонентам. В процесі інвестування потрібно визначити найбільш ефективні компоненти вкладень в людський капітал.

Безумовно, що психофрізіологічний стан стає базовою компонентою формування людського капіталу, а також його утворення, розвитку. Визначимо цю компоненту як психологічний капітал та фрізичний капітал людини.

Посилення фрізичного капіталу людини потребує, в першу чергу, визначення рівня його стану та переліку об'єктивних статистичних показників. До їх складу можливо включити інформацію про стан охорони здоров'я в державі з метою використання її при прийнятті рішень про інвестиції в розвиток людського капіталу. Знання про причини і стан хвороби мають важливе значення для здійснення інвестицій в фізичний капітал в системі охорони здоров'я. Інформація про дієвість заходів 3 
охорони здоров'я необхідна для державних інвестицій в систему охорони здоров'я. Для посилення фрізичного капіталу людини в національній економіці потрібні статистичні показники про стан охорони здоров'я в державі, які можливо використовувати при прийнятті рішень про інвестиції в розвиток фізичного капіталу. Для забезпечення зростання національної економіки вкладення в фрізичний капітал стають достатньо актуальними та необхідними в забезпеченні здорового стану нації.

Самим якісним та найпоказовішим індикатором стану здоров'я, який існує протягом тривалого часу і загальнопоширений, є смертність. В історії існує велика кількість пов'язаних з цим заходів в області охорони здоров'я.

Ряд другорядних, але не менш важливих показників стану фрізичного капіталу, складається з наступних: висота і вага для дорослих і для дітей під час економічного зростання країни, вага немовляти, індекс маси тіла, хронічні та інфекційні показники захворюваності. Наведені індикатори визначаються історично. Потрібно зауважити, що об'єктивні прямі показники якості життя та фрізичного капіталу в цілому ще відсутні.

Підкреслимо, що людський капітал національної економіки уособлює в собі запас виробничих навичок, талантів, здоров'я і досвіду людини. В той же час здоров'я носіїв людського капіталу $є$ базовою складовою. Тому розвиток людського капіталу національної економіки неможливий без прискіпливої уваги на всіх рівнях до стану охорони здоров'я населення.

Соціальний капітал вважається ґрунтовним чинником успішної соціальної інтеграції та адаптації особистості в соціум. Соціальний капітал - накопичення, що виникають в результаті суспільних відносин. Необхідною базою його виникнення та існування $€$ наявність суспільного оточення, соціального середовища. Він поєднує норми взаємовідносин, соціальні зв'язки, навички колективних дій, базується на людській довірі, толерантності та відповідальності. Соціальний капітал вважається потужним двигуном суспільства, який в змозі вирішувати питання не підйомні для держави та виробляти «соціальні рішення». Виходячи 3 вищенаведеного, соціальний капітал набуває нового статусу, нових повноважень та можливостей. Зміни в соціальному житті соціуму ініціюють 
нову його якість, яку доцільно визначити як «соціум-капітал».

В провідних дослідженнях вже не йде мова про індивідуальність. Все розглядається на рівні акумульованого капіталу. Постійно виникають нові форми суспільного життя. Особистість може стати продуцентом нової конфігурації соціуму для інших.

Робота в задоволеному соціумі дає більш плідні результати, а також $є$ кращою роботою для індивідуума з точки зору добробуту. Переваги соціумкапіталу різноманітні: він посилює інновації, людський капітал в цілому, зменшує оборотність працівників та позитивно впливає на кар'єрне зростання працівників.

Високий рівень соціального капіталу також підтримує інші сорери людського капіталу. Наприклад, це сприяє розвитку знань окремих осіб та організацій шляхом створення можливостей для обміну навичками на робочому місці [65]. Соціальний капітал також впливає на захищеність 3 охорони праці. Що стосується безпеки праці на виробництві, то можна говорити про капітал безпеки, який також можна визначити як частину людського капіталу. Капітал безпеки включає, наприклад, здатність працівників передбачати та виявляти ризики та загрози, а також здатність реагувати на надзвичайні ситуації та діяти в них. Соціальне забезпечення, пов'язане з безпекою праці (наприклад, взаємодія з безпекою, сприяння та підтримка його на робочому місці) допомагає працівникам ділитися навичками, пов'язаними з компетентністю на роботі.

Пошук нових рішень та ідей часто вимагає взаємодії 3 іншими компонентами зовнішнього або внутрішнього середовища [90]. Значення соціум-капіталу специфічно тим фактом, що на робочому місці при наявності культури налаштованого співробітництва індивідуум має можливість використовувати мережі та допомагати колегам при вирішенні проблем та труднощів на роботі. Обмін інформацією між колегами має важливе значення для інновацій, тобто комерціалізації та творчості, в якому соціум-капітал позитивно впливає на продуктивність індивідуума. Чим більше працівник має змогу використовувати свої зв'язки та соціальну підтримку колег по роботі, тим більше у нього віддача від праці. Завдяки 
злагодженому співробітництву та взаємодії, компетентність персоналу, що працює в організації, розвивається, створюючи передумови для організаційних інновацій. Соціум-капітал також проявляється в налагодженій робочій атмосфері, що важливо для кожної окремої особистості.

В площині соціального капіталу формується політичний капітал. Він напряму пов'язаний з потенціалом суспільства і виступає місткою складовою людського капіталу. Політичний капітал базується на вірі, визнанні. Розглядається як міра довіри, доброї волі, впливовості політика в суспільстві. Політичний капітал за своєю природою вважається надбанням, а не вродженою властивістю особистості, соціуму. Він має здатність до накопичення 3 віком. 3 досвідом. Політичний капітал фрормується при взаємодії держави та громадянського суспільства під впливом політики.

На верхівці та перетину творчого, інтелектуального, культурного капіталів формується креативний капітал. В економічній науці його виділено окремо на початку 21 століття. Креативний капітал базується на якісному фрізичному капіталі, використовує унікальні можливості індивідуума, його здатність до креативного мислення, відмінного від думок інших індивідуумів. Креативний капітал реалізується у вигляді інновацій, відкриття, винаходів, ноу-хау, інших продуктів інтелектуальної власності. Основні риси, які притаманні креативним особам, $€$ продукування особливих ідей, нетрадиційне мислення, допитливість, бажання постійної освіти, потяг до обміну знань, прагнення до нових знань, обізнаність щодо інновацій.

Психологічний капітал, ключовими елементами якого $€$ наполегливість, міцність, стійкість, впевненість в собі, оптимізм та сподівання було визнано найбільш необхідним для суспільного життя, для формування людського капіталу чинником. Психологічний капітал визнаний ключовим фактором та виграє центральну роль в індивідуальному успіху та благополуччі особистості, але він також відіграє певну роль у роботі організації та національній економіці [3]. Важливими характеристиками психологічного капіталу на сьогодні $€$ зміна здатності, самопізнання, навички управління та вміння поводитися. 
Психологічний капітал працівника сприяє особистому благополуччю завдяки ентузіазму, прихильності, позитивності та ініціативності, але й водночас і успіху діяльності організації. На практиці на психологічному капіталі ґрунтується мотивація індивідуума до праці, до впровадження інновацій, до розвитку унікальних можливостей людського капіталу, новаторських здібностей та до багатьох інших складових людського капіталу.

Індивідуальні ресурси, особливо психологічний капітал, пов'язані 3 тим, наскільки добре індивідуум оцінює свою роботу та наскільки креативно працює на своїй роботі. Індивідууми, які мають високий психологічний капітал, показують вищу продуктивність, ніж їхні колеги, з більш низьким психологічним капіталом. Рішення та дії керівників з високою оцінкою психологічного капіталу часто є більш позитивними, ніж у керівників, що мають низький рівень психологічного капіталу.

Вагомість впливу психологічного капіталу на результати діяльності на всіх рівнях не дивує. Високий психологічний капітал пов'язаний 3 позитивними очікуваннями від майбутнього, в яких, як вважають, робота полегшує важкі та складні ситуації [78]. Перед обличчям негараздів доцільніше шукати альтернативні способи досягнення важливих цілей. В такому випадку високий рівень психологічного капіталу допомагає чітко окреслити нові задачі для індивідуума, що має важливе значення для роботи працівника [79]. Психологічний капітал додає позитивних емоцій, які, у свою чергу, пов'язані з відносинами та навичками робочого середовища. Позитивні емоції також допомагають зосередити увагу та сконцентруватися на нових можливостях, що пропонуються навколишнім середовищем.

Персональне ставлення до праці, готовність до навчання, ентузіазм до роботи важливі для ефективності економіки. Чим більше індивідуальний вклад людського капіталу в національну економіку, тим більший суспільний ефект від вкладень в нього. За практичними дослідженнями, ставлення до роботи, прагнення навчатися, робочий ентузіазм важливіші фрактори успіху, навіть за професіоналізм та компетентність [56]. Чим більше вищеозначені фактори, тим більше ефект від їх використання та вкладень в них. 
Вкладення в людський капітал в період ринкового розвитку економіки вважаються новим інструментом для вимірювання соціально-економічного прогресу держави та потенціалу як благополучних країн, так і таких, що розвиваються [31].

Тому акцентування на розвитку саме психофізичної складової людського капіталу дозволить національній економіці отримати додаткові переваги для зростання. Поєднання психічного та фрізичного капіталів створює основу для сталого робочого життя та продуктивності праці, для управління людським капіталом, його розвитку. Аналіз залежності зростання людського капіталу від його різних компонент є перспективним для подальших досліджень, тому що проблеми сучасного робочого життя тісно пов'язані з психосоціальним благополуччям на роботі.

На істотному психологічному та фрізичному капіталі ґрунтується освітній капітал. Новий виток економіки - економіка знань, зумовлює потребу в людському капіталі з новітніми знаннями, навичками, вміннями, тобто з більш високою конкурентоспроможністю, що, в свою чергу, висуває нові вимоги до такої складової людського капіталу, як освіта [42]. Вона має величезний вплив на зростання людського капіталу. Ефективність розвитку національної економіки сучасної держави в значній мірі залежить від того, скільки коштів вона інвестувала в освіту громадян. Серед основних форм вкладань в людський капітал економістами виділяються освіта, підготовка та перепідготовка на підприємстві, підвищення рівня знань, що спричиняє збільшення обсягу освітнього капіталу у складі людського капіталу. Освіта не втрачає свого значення, але її результати $€$ непередбаченими і тому підлягають перегляду основних підходів, плануванню.

Така складова людського капіталу, як творчий капітал, виступає необхідним та невід'ємним фактором науково-технічного прогресу та науково-технічної революції. Його складники - знання, інформація, досвід, організаційні можливості, інфрормаційні канали, які, окрім інших преференцій, виступають підставою для реалізації матеріальної складової людського капіталу. Тобто наявність значного творчого капіталу та його втілення в життя, перетворення на працю передбачає його оплату, 
отримання носієм творчого капіталу винагороди. Творчий капітал складник конкурентоспроможності на всіх рівнях. До речі, творчий капітал $є$ ще мало досліджений в Україні.

Необмеженість знань, вільне володіння інформаційним простором, професійні навички стають інструментарієм для створення інтелектуального капіталу. Інтелектуальний капітал на відміну від творчого, освітнього, є більш формалізованим та стандартизованим, а, отже, інституціоналізованим. В даному аспекті він зазначається в патентах, свідоцтвах, в інших документах, що засвідчують права інтелектуальної власності.

Підставою для високоморального розвитку людського капіталу служить культурний капітал. Він уособлює в собі набуті культурні знання, компетенції, базується на освітньому та творчому капіталах, вносить спрямованоорієнтуючий вектор в життєдіяльність особистості.

Розвиток вищеозначених компонент людського капіталу неможливий без наявності комунікативного капіталу, який виступає джерелом формування психологічних та соціальних характеристик індивідуума. Комунікативний капітал передбачає наявність у індивідуума мовних навичок, навичок спілкування та поводження в процесі комунікації, визначається як здатність до мовленої активності. Комунікативний капітал служить міцним конкурентним фактором як на індивідуальному, так і на організаційному рівнях та в межах національної економіки.

Заснований на всіх без виключення компонентах людського капіталу професіоналізм формулюється у вигляді професійного капіталу. Складовими професійного капіталу виступають профресійні знання, навички, вміння, зв'язки, реальні результати професійної діяльності, професійний досвід, мотивація. Він необхідний для виконання професійних задач та обов'язків в процесі праці.

Гармонійне поєднання вищеозначених компонентів людського капіталу національної економіки формує елітний конкурентоспроможний потенціал держави, здатний продукувати високоякісний валовий національний продукт. 
Акцентування на розвитку визначених конкретних компонентів людського капіталу дозволить національній економіці отримати додаткові переваги для зростання, тому є перспективним напрямом дослідження.

Нематеріальні ресурси, пов'язані з індивідуумом, людський капітал, визначаються доволі складно, оскільки залежить від досвіду, культури, освіти, фрормуються під впливом робочих процесів, а також відносин та новаторських ідей людей. Це змушує звертати увагу на організаційну культуру, а також на ставлення та мотивацію персоналу. Новий, більш самоініціативний, самостійний та більш підприємницький підхід до роботи може бути побудований зі стійким, мотивованим та вправним людським капіталом.

Структура компонентів капіталу (наприклад, лідерство, практика нагляду - контролю, практика розвитку персоналу та управління) $\epsilon$ ресурсами, що забезпечують безперервність конкурентних переваг людського капіталу.

Людський капітал втілює нематеріальні, ресурсномісткі компоненти, що сприяють його успішній реалізації. Спрямування економічної думки на продовження терміну застосування людського капіталу пояснюється декількома глибинними факторами.

Питання тривалості використання та функціонування людського капіталу напряму пов'язане 3 економічними вигодами національної економіки. Значні вкладення в його розвиток потребують визначеного терміну окупності, який можливо досить точно підрахувати математичним шляхом. Тому, як мінімум, тривалість використання людського капіталу потрібна бути не менше за визначений термін окупності інвестицій в людський капітал. Вкладення в людський капітал в період ринкового розвитку економіки вважаються новим інструментом для вимірювання соціально-економічного прогресу держави та потенціалу як благополучних країн, так і таких, що розвиваються [31].

Мета подовження тривалості використання полягає також в тому, щоб відкласти пенсійний вік кожного носія людського капіталу і таким чином продовжити робоче життя, кар'єру. Термін використання людського капіталу 
також відбивається на рентабельності підприємства. За результатами діяльності підприємства можливо виміряти продуктивність, рентабельність, інноваційність та якість людського капіталу. Ефективність окремого носія або групи вимірюється кількістю або якістю роботи. Сьогоднішній зміст робочого життя визначає здатність адаптувати людський капітал до роботи та ринкових умов та регулювати ці взаємовідносини.

В даному відношенні людський капітал національної економіки виступає як промоутер здатності до зміни людського капіталу індивіда.

Визначення впливовості компонентів людського капіталу на тривалість його використання в сферах національної економіки розглядає актуальні проблеми тривалості використання людського капіталу та прагне знайти теоретичне підґрунтя для пошуку практичних можливостей його подовження.

Тривалість використання та фрункціонування людського капіталу розглянуто в розрізі використання окремих найбільш впливових на термін тривалості компонентів людського капіталу національної економіки: фрізіологічного, психологічного, освітнього, творчого, креативного, професійного, соціального капіталів.

Людський капітал пов'язаний з тривалістю і цілісністю робочої кар'єри багатьма різними способами доволі різноманітно. Останні роки в Україні тривалість використання людського капіталу зростає, що пов'язано як 3 неформальними, так і фрормальними фракторами. Значною мірою даному процесу сприяло збільшення на законодавчому рівні пенсійного віку працездатного населення. Також фрормальним фрактором слугує можливість отримання додаткового доходу - працюючий пенсіонер до пенсії отримує ще й заробітну плату.

Пенсіонери завжди відносились до вразливих верств населення, які в період ускладнення економічної ситуації в країні страждають в першу чергу. В цих умовах важливу роль відіграє саме інституційне підґрунтя управління процесами забезпечення достатнього прожиткового рівня пенсіонерів.

За даними Світового банку, Україна за темпами старіння населення 
посідає в Європі перше місце [50, с. 7]. При збережені існуючих тенденцій населення України до 2025 р. скоротиться на п'яту частину від сьогоднішнього рівня. Країни Східної Європи та колишнього СРСР нині долають так званий третій перехідний період - період старіння населення. При чому, прогнозуючи розвиток демографрічної ситуації до 2050 р., українські урядовці та Міжнародний центр перспективних досліджень доводять, що населення України зменшиться до 28,9 млн. осіб, а частка осіб віком понад 60 років становитиме 31\%. Чисельність населення працездатного віку до 2050 р. скоротиться майже вдвічі: з 30,3 млн. у 2005 р. до 16 млн. осіб [23, с. 3]. Це вплине на трудовий потенціал України, а також на перспективи стійкого економічного зростання.

Збільшення в структурі населення осіб похилого віку створює додаткове навантаження на державний бюджет та пенсійні фонди. Перед державами постає проблема реформування систем пенсійного забезпечення та охорони здоров'я.

В пенсійній системі України на 10 платників внесків припадає вісім пенсіонерів.

Недостатня увага з боку держави до вирішення вищезазначених питань може призвести у майбутньому до руйнування всієї системи пенсійного забезпечення, коли працездатне населення не зможе забезпечувати видатки пенсійного фонду, які становлять близько $15 \%$ валового внутрішнього продукту.

Досягнутий в Україні рівень пенсій не можна вважати достатнім. Середній розмір пенсій складає лише $41 \%$ середнього рівня заробітної плати. У разі приведення у відповідність темпів зростання зарплати та пенсій, бюджет Пенсійного фонду стане дефріцитним.

На нашу думку, саме держава повинна стати гарантом забезпечення прав пенсіонерів на отримання достойної пенсії, у зв'язку з чим стає вкрай необхідним реформування пенсійного законодавства і пенсійних інститутів. Стратегія України стосовно літніх громадян має бути зорієнтована на посилення їх правового захисту, забезпечення гідного рівня життя, сприяння трудової зайнятості. 
За цих умов особливо гостро постає проблема забезпечення достатнього життєвого рівня пенсіонерів, реформування пенсійного забезпечення. Виявлення реальної ситуації в їх положенні, створення відповідної законодавчої бази та інститутів, забезпечення та збереження соціальної рівності для цих прошарків населення $€$ важливою задачею на всіх рівнях державного управління.

Навантаження на одного найманого працівника (співвідношення найманих працівників та постійного населення) по Україні складало 2,2 та 2,1 осіб з числа постійного населення. Кількість пенсіонерів невпинно зростає всупереч скороченню наявного населення та найманих працівників.

Показники свідчать про старіння населення та трудових ресурсів.

Представимо наглядно структуру кількості пенсіонерів за видами пенсій.

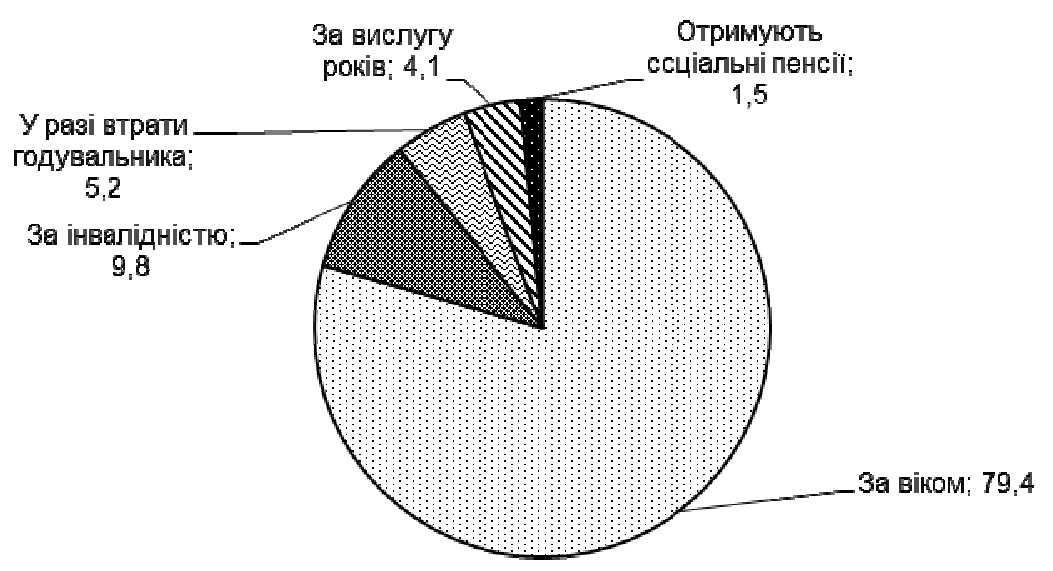

Рис. 3.2. Структура кількості пенсіонерів за видами пенсій, \%

За даними рис. 3.2. основними видами пенсій $€$ пенсії за віком кількість пенсіонерів складає 79,4 \% та пенсії за інвалідністю - 9,8\%.

Але не всі пенсіонери залишають робоче місце при отриманні пенсії. Частина з них працює, чим поповнює державний бюджет та соціальні фонди та таким чином компенсує витрати держави на пенсійне забезпечення.

Українські пенсіонери схильні морально та вимушені матеріально до 
подовження своєї трудової діяльності після настання пенсійного віку. В Україні понад 20\% осіб 60-70-річного віку працюють. Саме тому державні та пенсійні інститути повинні запроваджувати заходи, що допоможуть похилим громадянам залишитися соціально затребуваними, активними та корисними.

Якщо до 2008 р. спостерігалася позитивна тенденція до збільшення кількості працюючих пенсіонерів, то в 2008 р. цей показник скоротився на 3\%, що обумовлено, насамперед, скороченням та поширеним звільненням пенсіонерів у зв'язку з згортанням виробництва на підприємствах.

Світова фінансова криза позначиться на структурі зайнятості. За прогнозами, доля працівників сфери матеріального виробництва значно перевищить кількість працюючих в інших галузях економіки. Серед фахівців робітничих професій найбільш актуальними будуть фрезерувальники, ливарники, столяри, швачки, токарі, муляри, електромонтери. До зони ризику можуть потрапити фахівці з нерухомості та банківської справи, фондові аналітики, працівники будівельних та торговельних фрірм [4, с. 3].

$62 \%$ осіб передпенсійного віку $€$ економічно активними. Серед пенсіонерів 60-70 річного віку працювало 20,2\% осіб. Цей показник безупинно скорочується, що пов'язано, в першу чергу зі скороченням персоналу на підприємствах та збільшенням кількості безробітних. Експерти прогнозують, що безробіття, в першу чергу, обійме будівельників, металургів, хіміків, спочатку - з низьким кваліфрікаційним рівнем, а також осіб пенсійного та передпенсійного віку, потім - і висококваліфіковані кадри $[49$, c. 2].

Проведений аналіз показав, що 30,4\% осіб є пенсіонерами. Кількість пенсіонерів в Україні невпинно зростає всупереч скороченню наявного населення та найманих працівників, що свідчить про старіння населення.

Так, в 1990 р. на 1000 працездатних працівників приходилося 498 пенсіонерів, а вже в 2008 р. - 653 особи. Якщо до 2008 р. спостерігалася позитивна тенденція до збільшення кількості працюючих пенсіонерів, то 3 2008 р. - спад, обумовлений, насамперед, скороченням та поширеним звільненням пенсіонерів у зв'язку з згортанням виробництва на 
підприємствах.

Таким чином, пенсіонери відносяться до найбільш вразливих верств населення, що потерпають в першу чергу при економічних змінах в країні. Тому для реформування пенсійного забезпечення в Україні потрібно забезпечити:

- активні зусилля по залученню до праці населення (для збільшення пенсійних внесків);

- розвиток конкурентоспроможності товаровиробників на внутрішньому та міжнародному ринках;

- детінізацію доходів громадян;

- розвиток співпраці України з міжнародними інституціями (СОT, МОП, Світовим банком);

- введення в дію заходів, спрямованих на пом'якшення ситуації на ринку праці;

- $з$ боку уряду - перерозподіл коштів соціальних фондів між фондами з метою спрямування їх на підтримку безробітних та пенсіонерів;

- законодавче підґрунтя для завчасного виходу на пенсію до досягнення особою пенсійного віку;

- заохочення осіб пенсійного віку до ведення підприємницької діяльності;

- зменшення відрахувань в пенсійний фонд з осіб пенсійного віку - 3 метою стимулювання роботодавців до залучення до праці пенсіонерів;

- розробку механізму залежності розміру пенсій від кількості сплачених внесків.

- індивідуалізацію розмірів внесків.

Реформування повинно передбачати насамперед законодавче урегулювання питань забезпечення достатнього прожиткового рівня пенсіонерів з вдосконаленням інститутів праці та пенсійного забезпечення.

До неформальних фракторів віднесемо можливість відчувати себе соціально затребуваними.

Відправною точкою для подовження функціонування та використання людського капіталу служить фрізіологічний капітал. Саме від рівня його 
наявності залежить вагомість всіх інших складових людського капіталу. Процес подовження будується на припущенні, що професійні здатності і здоров'я індивіда є фундаментальним підґрунтям для людського капіталу. Здоров'я надає більше можливостей для придбання як освіти, так і досвіду роботи, а також сприяє успіхам в навчанні, праці. Для роботодавця збереження працездатності працівників $є$ важливою передумовою для того, щоб інвестиції в людський капітал були вигідними. Наявність хвороб та ранній вихід на пенсію викликають тимчасову або постійну втрату людського капіталу та послаблюють продуктивність його розвитку. Подовження терміну використання людського капіталу створюється робочою здатністю людей працювати, безпечною та здоровою роботою, заходами з безпеки праці, ергономічними заходами. Проте важливо зазначити, що основу для подовження використання людського капіталу створює сама робота - її змістовність. Особливо гнучкі робочі процеси, можливості лідерства та впливу на власну роботу створюють стійку та необхідну основу та підстави для ії̈ продовження.

Така невід'ємна компонента людського капіталу як соціальний капітал при недостатньому розвитку, низькому рівні негативно впливає на здоров'я та добробут працівників. Прогалини в соціальному капіталі, наприклад, незручна без довіри атмосфера, відсутність підтримки з боку інших працівників, переслідування, тиск, підвищують ризик розвитку психічних проблем зі здоров'ям, таким як депресія [71, 72], що, в свою чергу, скорочує працездатний термін.

Натомість, високий соціальний капітал, такий як сприятлива робоча атмосфрера, взаємна повага робочого співтовариства, демонструє підвищення добробуту працівників, зменшення та скорочення відпусток по хворобі [67]. Позитивні взаємовідносини та взаємодії в робочому середовищі, їх висока якість відображаються у дружбі між працівниками, що стає ще одним неформальним фактором подовження функціонування людського капіталу. Налагоджені зв'язки з зовнішніми клієнтами, відносини з партнерами також відіграють позитивну роль в процесі подовження.

Соціальний капітал в контексті людського капіталу актуальний з точки 
зору розвитку робочої кар'єри. По-перше, соціальний капітал створює умови для продовження роботи персоналу. По-друге, коли працівники отримують соціальну підтримку та заохочення на робочому місці, що $\epsilon$ цінним методом управління, вони, як правило, більш позитивно ставляться до продовження своєї роботи. Особливо, якщо робота кількісно або психологічно виснажлива, необхідна підтримка керівника та обговорення 3 ним проблем, пов'язаних із роботою. Без соціальної підтримки керівників і колег, працівники частіше виходять на пенсію раніше. По-третє, доцільно говорити про зниження соціального капіталу серед 41-50-річних і старше 50-ти років працівників, що змушує їх припиняти роботу.

3 точки зору людського капіталу, проблемами створення та експлуатації соціального капіталу стають висока плинність працівників, періодичний перехід їх з однієї роботи на іншу та на різні робочі посади, тимчасовість працівників, швидкість темпів зміни робочих місць, невизначеність та тимчасовість характеру робочих місць та структур. Велика кількість постійно працюючих на одному робочому місці багато років не сприяє розвитку нових ідей, креативності, бажанню змін. Відсутність мотивів до формування налагодженого робочого середовища, яке $є$ центром соціального капіталу, особливо актуально для тимчасових працівників, які часто мають незначний доступ до робочого соціуму, де вони працюють, через обмеженість їх трудових відносин.

Такі складові соціального капіталу, як соціальна підтримка і передова практика управління, впливають на подовження терміну роботи на робочому місті. Досвід роботи, у свою чергу, пов'язаний з добробутом працівників та працездатністю. Соціальна підтримка, повага, відчуття власної потрібності стимулює працівників старшого віку до подовження термінів праці. Чим більше співробітники відчувають достатність роботи, тим менше вони бажають вийти на пенсію до офріційного пенсійного віку, і тим більше опікуються продовженням роботи після настання пенсійного віку.

Вміння працювати та професійні навички, рівень майстерності, потенціал розвитку власної кар'єри, здатність до продукування ноу-хау - 
складники професійного, творчого капіталів - $€$ необхідними передумовами для подовження ффункціонування людського капіталу. Висока майстерність, компетентність надають почуття задоволеності роботою. Професіоналізм запобігає порушенню добробуту, допомагає працювати в непередбачених та складних ситуаціях відповідним чином.

Освітній капітал - важлива складова для подовження тривалості використання людського капіталу. Згідно з деякими теоретичними моделями, знання $€$ навіть елементом благополуччя на роботі [42]. У науці прискіплива увага до даного питання призвела до появи нового напряму економіки знань [38]. Розвиток освіти, компетенції також стосується мотивації роботи та прихильності до корпоративного духу організації.

Рівень освіти пояснює участь у процесі праці людей працездатного віку. 90 \% осіб з вищою освітою задіяні в сфрері зайнятості, тоді як серед осіб з базовою освітою цей показник становить лише 65\%.

Дослідження показали важливість освіти та навчання на роботі для продовження кар'єри. Для осіб 40-49-річного віку це можливості розвинути свої професійні навички, для осіб у віці старше 50 років це можливості для участі в процесі праці, що спонукають їх продовжувати свою роботу [45]. Можливості розвитку та самозайнятості у старших вікових групах істотно знижують фрактичний пенсійний вік.

На сьогоднішній день усталеної вищої освіти часто недостатньо для роботи на ринку праці, тому що постійна зміна в робочому середовищі вимагає такої складової, як наявність креативного капіталу, наприклад, здатності сприймати новизну та продукувати нові ідеї. Бажання постійно вчитися новим та індивідуальним знанням та навичкам (тобто навичкам, які можуть бути використані у кількох роботах або завданнях) сприяє успіху [28]. Значення такого людського капіталу для трудового життя індивіда може бути актуальним в майбутньому. Саморозвиток та змістовність навчання залежать від індивіда. Але установки та можливості для освіти і навчання на робочому місці може надати роботодавець. Вищенаведені аспекти розвитку власних професійних навичок забезпечують захист працівників на ринку праці, а національну економіку - стабільним людським 
капіталом.

Дослідження психологічного капіталу та добробуту на роботі свідчить про зв'язок психологічного капіталу з розумовим добробутом працівників. Психологічний капітал - впевненість в собі, надії, реалістичний оптимізм та наполегливість, позитивно впливає на задоволеність роботою, подовження загальних термінів праці. Хороший психологічний капітал також сприяє підтримці людського капіталу під час безробіття, що, в свою чергу, збільшує ресурси особистості для того, щоб прагнути знайти роботу.

Психологічний капітал позитивно пов'язаний з вірою працівника в свою здатність до працевлаштування. Коли людина вірить у власні можливості працевлаштування, вона активно прагне знайти нову роботу. Працівники, які вірять у можливість власної зайнятості, стають більш енергійними та більш задоволені роботою, ніж ті, хто не вірить у отримання результату. Чим більше індивід вірить у власну здатність отримати роботу, тим менше відчувається невизначеність роботи.

Зайнятість пов'язана з меншим виснаженням та психологічним синдромом як у в умовах постійного, так і сезонного працевлаштування. Трудове завантаження, режим праці знижують відчуття незахищеності та, як наслідок, виснаження, але, з іншого боку, незадоволеність роботою зумовлює зниження можливостей для працевлаштування та викликає безпорадність.

\section{4. Інвестиції в людський капітал як основа розвитку національної економіки}

Європейський вектор розвитку України, намагання держави забезпечити гідний рівень життя у своїй країні передбачають забезпечення зростання національної економіки. Стабільне економічне зростання залежить від системної побудови та взаємодії економічних важелів та чинників. За Конституцією України, людина проголошена найвищою соціальною цінністю [15].

Прискіплива увага до життя кожної окремої особистості забезпечує 
державі позитивний імідж, а її населення не тільки з надією дивиться на майбутнє, а й з задоволенням живе в рідній країні, зі свого боку забезпечуючи функціонування національної економіки шляхом вкладень власного людського капіталу.

Дослідники економічного зростання національної економіки [3; $18 ; 27$; 51] визнають, що сучасним дієвим інструментом, серед інших чинників, розширеного відтворення суспільного виробництва стає людський капітал Жорстка боротьба в розвинутому конкурентному середовищі сприяє підвищенню якості людського капіталу, який позиціонується на ринку виробників товарів і послуг. Стрімкий індустріальний розвиток суспільства потребує більш високий рівень життя людей, які, в свою чергу, бажають отримувати товари, послуги, роботи відповідного змісту. Природно, що в цих умовах, виробник вимушений залучити такі ресурси, які зможуть створити йому потрібні товари, послуги, роботи.

При цьому кожний процес, спрямований на продукування конкурентоспроможних товарів, послуг, робіт вимагає вкладень. Найбільш актуальні та ефрективні вкладання в людський капітал.

Доцільність та необхідність суттєвих вкладень в людський капітал для забезпечення зростання національної економіки стало метою дослідження. Згідно мети поставлені та вирішені завдання: з'ясувати доцільність вкладень в людський капітал для забезпечення зростання національної економіки; розробити напрями вкладень в людський капітал для забезпечення зростання національної економіки; визначити залежність складових людського капіталу.

Проведений аналіз показників за даними Державної служби статистики України [35] свідчить про зниження економічної стійкості України, нарощування темпів інфляції. Динаміка валового внутрішнього продукту у фактичних цінах на перший погляд позитивно характеризує економічний стан країни. Так, в 2010 році показник складав 1,12 трлн. грн., 1,35 трлн. грн. - в 2011 році, 1,46 трлн. грн. - в 2012 році, 1,52 трлн. грн. - в 2013 році, 1,59 трлн. грн. - в 2014 році, 1,99 трлн. грн. - в 2015 році, 2,38 трлн. грн. - в 2016 році [35]. Але індекси фрізичного обсягу валового 
внутрішнього продукту протягом років знижуються зі 104,1 у 2010 році до 90,2 у 2015 році [35]. Також у постійних цінах 2010 року відбувається від'ємна зміна обсягу валового внутрішнього продукту до попереднього року (-6,6 \% в 2014 році, -9,8 \% в 2015 році). Лише в 2016 році показник складає 2,3 \% зростання до 2015 року [47]. Але ж зниження в 2015/2014 роках відбулося на 9,8 \%, тобто взагалі не досягнутий навіть рівень 2014 року.

Позитивна динаміка валового внутрішнього продукту у фрактичних цінах обумовлена зростанням індекса споживчих цін (124,9 в 2014 році, 143,3 в 2015 році, 112,4 в 2016 році, 112,5 за січень - листопад 2017 року) [14]. Відсутність позитивних політичних зрушень в зовнішній ситуації, наростання та спади внутрішніх конфліктів, неоднозначні процеси демократизації українського суспільства, втрата економічних зв'язків та стратегічних партнерів, спрямування державного бюджету на військові операції, вимоги від зарубіжних фрінансових партнерів (канадський уряд, уряд США) щодо обов'язкового реформування збройних Сил України, ряд інших фракторів - все це не сприяє плановому економічному розвитку держави. Ряд дослідників [24] серед глибинних причин економічного спаду називають також надлишкові сподівання українського уряду на стихійне регулювання ринку (за принципом невидимої руки А. Сміта).

Провідна задача держави, сподівання населення - це економічне зростання України. Для забезпечення підйому національної економіки потрібен пошук доцільних напрямів розвитку, які стануть основою благополуччя.

Кожна країна визначає пріоритетність видатків, вкладень та розраховує ефрект від них. Серед існуючих сценаріїв розвитку України, ряд дослідників визначають як ефективний розвиток країни через вкладання в людський капітал [3; 18; 24].

Така вагома роль людського капіталу на національному рівні спричинила підвищення вимог до людського капіталу. Професійні знання і навички, старанність, ініціативність та комунікативність, наявність умінь практичного вирішення проблем, використання технічних засобів, доступ до 
інформації, інтелектуальний потенціал, креативність - це далеко не весь перелік особистісних якостей людського капіталу, що вимагає сучасність. В умовах економіки знань важливою характеристикою людського капіталу стає вміння застосовувати свої знання і широкий світогляд під час виконання роботи.

Вищеназвані аспекти викликають потребу у підготовці конкурентоспроможного на ринку праці людського капіталу, що потребує певних вкладень. Останнє дає ефект не тільки для національної економіки. Перспективність вкладень в людський капітал дає можливість забезпечити підвищення його конкурентоспроможності в майбутньому і, як наслідок, більш високу його вартість, що, в свою чергу, забезпечує зростання добробуту конкретної особи, населення.

Вкладення в людський капітал в період ринкового розвитку економіки вважаються новим інструментом для вимірювання соціально-економічного прогресу держави та потенціалу як благополучних країн, так і таких, що розвиваються [18; 31; 39]. Вкладення в людський капітал спрямовані на формування і розвиток його можливостей. Ефективність вкладень залежить від відповідності напрямів вкладень особистісним інтересам носія людського капіталу для його продуктивної діяльності та відповідності потребам суспільства. При цьому вважається, що людський капітал $є$ важливою формою кінцевих капіталовкладень суспільства, рівень його розвитку визначає динаміку та рівень життя не тільки країни, але й світового співтовариства в цілому [36].

Р. Беккер описав людський капітал як певний запас знань, навичок, мотивацій [54]. Спочатку вроджений різноманітний запас знань, навичок, здібностей, мотивацій став підставою для розвитку конкурентних відносин між носіями людського капіталу. Таке явище надало їм певних конкурентних переваг і забезпечило визначений рівень конкурентоспроможності. Розвиток конкурентоспроможності людського капіталу $є$ ключовим фрактором не тільки для національного зростання економіки, а й глобального.

Вкладення в людський капітал здійснюються на трьох рівнях - 
мікрорівні (безпосереднім носієм людського капіталу, підприємством, яке володіє людським капіталом); макрорівні (країною); мегарівні (групами країн, об'єднаннями, фондами, союзами, спілками, мегакомпаніями та глобальними світовими корпораціями). Не враховувати важливість наявності різних рівнів вкладень неможливо, тому що для розвитку національної економіки має значення певне поєднання, співвідношення, співфінансування вкладень на різних рівнях. Воно визначає обсяг вкладень у людський капітал держави з урахуванням частки інших інвесторів.

3 позицій матеріальності вкладень в людський капітал дослідники розглядають матеріальні витрати, фізичні витрати, морально-психологічні 3 боку суб'єкта впливу (зовнішнього) на об'єкт впливу (людський капітал). На думку автора, в даному розподілі важливо виділити часові витрати. Таким чином, не всі вкладення або не в повному обсязі вимагають матеріальних витрат. Можуть бути витрати фрізичні (здоровий спосіб життя, спорт), емоційні (здоровий образ життя, заняття мистецтвом), психологічні, тобто нематеріальні витрати, які вимагають вкладень інших ресурсів.

Інвестор в людський капітал може бути як зовнішній (сім'я, підприємство, муніципалітет, держава, міжнародні фонди), так і сам носій людського капіталу. Величина вкладень у людський капітал залежить від ряду фракторів. В їх сукупності можна виділити об'єктивні (вік, стать, зовнішній вигляд, антропометричні дані, стан здоров'я) та суб'єктивні (наприклад, психологічні). Вкладення в людський капітал - в частині матеріальних витрат, виражених у грошовому еквіваленті - широко використовуються в методиках оцінки людського капіталу [3; 18].

В якості складових людського капіталу дослідники виділяють:

- знання, здоров'я, навички, досвід [54];

- вроджені та придбані здібності та якості [85];

- знання, продуктивні здібності, здоров'я, мотивація, мобільність [17];

- здоров'я, знання, навички, здібності, мотивації [6];

- знання, вміння, навички, зовнішність, здоров'я, освіту, професійну підготовку, практичний досвід, фрах, кваліфікацію [22];

- здоров'я, тривалість життя, трудова активність, наявність 
освіченості, сучасних знань, умінь і навичок, здібностей до перенавчання, адаптації до змін, мобільності [32].

В дослідженнях людського капіталу фахівці збігаються в найважливих складових людського капіталу - виховання, освіта, здоров'я, знання, розвиток підприємливості, культури, етики, заняття мистецтвами. Серед них базисними визначають виховання і освіту.

Підвищення інвестиційної активності бізнесу шляхом капіталовкладень у нові технології та обладнання зумовлює потребу в людському капіталі з новітніми знаннями, навичками, вміннями, тобто 3 більш високою конкурентоспроможністю. Це, в свою чергу, висуває нові вимоги до такої складової людського капіталу, як освіта [44; 5].

Аналіз видатків зведеного бюджету України (за даними [47]) свідчить, що традиційно видатки, які опосередковано можливо віднести як вкладення держави на розвиток людського капіталу в країні, складають 60-64 \% загальних видатків бюджету в 2010-2014 роках. Лише в 2015 та 2016 роках вони скоротилися до 56 та 57 \% відповідно за рахунок збільшення видатків на оборону, громадський порядок, безпеку та судову владу. В складі видатків, які опосередковано можливо віднести як вкладення держави на розвиток людського капіталу в країні, розглянуто видатки бюджету України на духовний та фізичний розвиток, видатки на охорону здоров'я, видатки на освіту, соціальний захист та соціальне забезпечення населення. Так, видатки бюджету України на духовний та фрізичний розвиток складають від 2 до 3 \% у структурі загальних видатків впродовж 2010-2015 років. Охорона здоров'я фрінансується в державному бюджеті України на рівні 11 \% від загальних видатків. На освіту держава витрачає 19-20 \% бюджету. В 20152016 році спостерігається відсоткове зниження даних витрат - до 17 та 15 \% відповідно. Вагому частину в загальних витратах бюджету України займають витрати на соціальний захист та соціальне забезпечення населення - традиційно це 28 \%. В 2016 році показник досяг рівня 31 \%. Значних зрушень у відсотковій структурі видатків, які опосередковано можливо віднести як вкладення держави на розвиток людського капіталу в країні, не спостерігається, тоді як в грошовому виразі вони зростають за 
всіма статтями витрат бюджету відповідно до росту загальної суми видатків.

Спираючись на системні власні дослідження та на висновки фахівців з людського капіталу, пропонуємо важливість складових людського капіталу визначати виключно з урахуванням умов використання людського капіталу.

Підтримка та розвиток складових людського капіталу вимагає значних вкладень. На необхідності інвестицій наголошує ряд дослідників людського капіталу: у здоров'я, освіту, умови життя [85], в освіту, емоційного та фрізичного здоров'я, поліпшення умов праці [18].

Перелік складових людського капіталу, які виділяють дослідники та який вищенаведений у роботі, надав підстави розробити напрями вкладень в людський капітал для забезпечення зростання національної економіки.

У структурі вкладень в людський капітал можливо виділити наступні складові: вкладення у виховання, початкова освіта, професійна освіта, вища освіта, перепідготовку, підвищення кваліфікації, практичний досвід, вкладення в здоровий спосіб життя, відпочинок, вкладення в спорт, заняття мистецтвом, розвиток творчих здібностей, розвиток вроджених здібностей і якостей, здоров'я, наукову діяльність, зовнішній вигляд, поліпшення умов праці, умови життя, мотивації, мобільність, адаптації до змін, розвиток підприємливості. При чому вкладення за різними складовими повинні бути збалансованими. Надання суттєвих переваг за окремими складовими викликає диспропорції у розвитку людського капіталу суспільства.

Розвиток національної економіки у сучасному розумінні більше не може розглядатися тільки як зростання обсягу матеріальних благ і послуг. Тільки економічні показники не можуть служити універсальними критеріями при розподілі суспільних ресурсів або при ранжуванні країн за рівнем розвитку. Останніми десятиліттями все більше уваги приділяється виміру економічного розвитку через людський капітал. Цей фракт відображений у багатьох програмних і аналітичних документах міжнародних організацій, ООН, Світового Банку та інших, починаючи з 1990 року.

Тому у сучасних економічних, управлінських теоріях з посеред 
матеріальних, фрінансових та інформаційних ресурсів, саме людський капітал розглядається як найважливіший фрактор, завдяки якому національна економіка може добитися успіху. Було визнано, що будь який розвиток держави неможливий без участі людського потенціалу. Інноваційна економіка так само розвивається на засадах людського капіталу. Ї̈̈ особливість полягає у тому, що в процесі її провадження мають приймати участь велика кількість високоосвічених людей, які займаються творчим процесом на сучасному унікальному інноваційно-технологічному ринку праці. Тому так гостро стоїть проблема підготовки висококваліфікованих, здатних до продуктивної праці, до самостійного набування знань фахівців.

Концепція використання ресурсів, втілених у людей, на відміну від ресурсів робочої сили, з'явилася вже в початковий період розвитку економічної думки з часів В. Петті на початку XVII століття. Походить вона від виявлення впливу, який на багатство нації має рівень освіти і вмінь її громадян. Такі набуті навички і знання було визнано фрормою постійного капіталу, оскільки явище подібно до того, коли капітал вимагає інвестицій і приносить певну ренту в майбутньому без здійснення торгівлі ним.

Подальші концепції людського капіталу, як основного фактора виробництва, проблеми інвестицій в людський капітал фрормувалися в працях таких класиків політичної економіки як Т. Шульц, Г. Беккер, Х. Боуен, А. Делі, М. Амстронг, Л. Туроу та ін.

Уявлення про те, що виробництво все більшої кількості товарів і послуг є найкращим шляхом підвищення життєвого рівня і вирішення інших загальнонаціональних завдань, є певною мірою застарілим та однобічним. Такий підхід призводить до недооцінки багатьох неекономічних параметрів розвитку національної економіки. Рівень життя людей може бути відносно низьким при фрормально високих показниках економічного росту. Можлива і протилежна ситуація - відносно високий рівень життя при помірних показниках економічного росту.

Останніми десятиріччями в мікроекономічних та макроекономічних дослідженнях визнається, що людина разом зі своїм інтелектуальним 
потенціалом і здібностями, являє собою стратегічний ресурс (його можна формувати, розвивати), який $€$ потенційно новим джерелом конкурентоспроможності як особистості, так і підприємств, національної економіки, світового господарства. Сучасні як вітчизняні, так і зарубіжні вчені, метою своїх досліджень ставлять вивчення життєдіяльності людини як носія суб'єктивованих знань і вмінь, що складають засади людського капіталу.

Г. Беккер, лауреат Нобелівської премії 1992 року, проаналізував вплив різних чинників на рівень індивідуальних інвестиції в людський капітал [7], а також оцінив прогнозовані з них доходи. Людський капітал це наявний у кожного запас знань, навичок, мотивацій. Інвестиції в нього можуть здійснюватися за такими напрями, як освіта, накопичення виробничого досвіду, охорона здоров'я, географічна мобільність, вміння пошуку інфрормації.

Відправним пунктом для Г.Беккера слугувало уявлення, що при вкладанні своїх коштів в підготовку і освіту, учні та їх батьки поводяться раціонально, зважуючи відповідні вигоди і витрати. Окрім того, інвестування в людський капітал не обмежене тільки освітою, хоча і вважається за основне джерело даного виду капіталу. Важливими джерелами є також знання, що здобуті від батьків, досвід і вміння, отримані як на робочому місці, так і взагалі від певної діяльності [54].

Теоретичні дослідження доводять, що людський капітал через свій вплив на поступ технічного прогресу $\epsilon$ невід'ємною детермінантою економічного зростання в довгостроковій перспективі. Численні емпіричні дослідження стосуються позитивного впливу кваліфікації і вмінь, а отже освіти та навчання працівників на темпи зростання. Про це свідчать визначення основних детермінантів у процесі фрормування концепцій людського капіталу (табл. 3.1).

Унікальність людського капіталу, порівняно з іншими ресурсами підприємства, розглядається як такий ресурс, що може підсилювати своє значення, в той час як інші ресурси залежно від термінів їх використання знецінюються. 
Таблиця 3.1

Ключові детермінанти формування концепцій людського

капіталу

\begin{tabular}{|c|c|}
\hline Автори & Основні детермінанти \\
\hline А. Сміт [87] & $\begin{array}{l}\text { Освіта і навчання мають бути визнані як інвестиції } \\
\text { у співробітників. Продуктивність праці робітників, } \\
\text { які мають певні навички, більш висока, ніж у } \\
\text { працівників без таких навичок }\end{array}$ \\
\hline Д. Мінсер [76] & $\begin{array}{l}\text { Розробив емпіричні основи теорії людського } \\
\text { капіталу. Визначив співвідношення розподілу } \\
\text { доходів в Америці з різною якістю освіти і } \\
\text { навчання за місцем роботи серед робітників, } \\
\text { підрахувавши, що в 1950-1960 річний дохід } \\
\text { виростав на 5-10\% за рік додаткового навчання }\end{array}$ \\
\hline Г. Беккер [54] & $\begin{array}{l}\text { Людський капітал - це наявний у кожного запас } \\
\text { знань, навичок, мотивацій. Інвестиціями в нього } \\
\text { можуть бути освіта, накопичення виробничого } \\
\text { досвіду, охорона здоров'я, географрічна } \\
\text { мобільність, пошук інфоомації. Відправним } \\
\text { пунктом служило уявлення, що при вкладанні } \\
\text { своїх коштів в підготовку і освіту учні та їх батьки } \\
\text { поводяться раціонально, зважуючи відповідні } \\
\text { вигоди і витрати }\end{array}$ \\
\hline Т. Шульц [86] & $\begin{array}{l}\text { Людський капітал - це всі людські здібності - як } \\
\text { вроджені, так і набуті. Властивості, які } є \text { цінними і } \\
\text { можуть бути розвиненими за допомогою } \\
\text { відповідних вкладень, визнаються людським } \\
\text { капіталом }\end{array}$ \\
\hline $\begin{array}{r}\text { Е. Долан, } \\
\text { Д. Ліндсей [10] }\end{array}$ & $\begin{array}{llr}\text { Людський } & \text { капітал розуміється у } & \text { вигляді } \\
\text { розумових } & \text { здібностей, отриманих } & \text { через } \\
\text { формальне навчання, освіту, або як практичний } \\
\text { досвід }\end{array}$ \\
\hline
\end{tabular}


Тому стратегічне управління людським капіталом вважається в даний час найважливішим фрактором, що дозволяє національній економіці впроваджувати динамічні зміни економічних умов, а співробітникам адаптуватися до змін поглядів і очікувань відносно професійної діяльності.

Різноманітні підходи до визначення людського капіталу розглядають працівників як активи, які формуються, підтримуються і які потребують інвестування. Інвестиції в людський капітал мають складний характер, а на цей час не існує поки що жодних загальноприйнятих методик його вимірювання.

Безумовно, однією з форм інвестиції $є$ освіта, однак, інші форми важко однозначно визначити і змоделювати. У 1964 році Г. Беккер розвинув ідею людського капіталу до рівня концепції, відповідно до якої отримання освіти і придбання додаткових навичок розглядаються як своєрідний інвестиційний проект [54]. Серед основних фрорм вкладення в людський капітал економістами виділяються освіта, підготовка та перепідготовка на підприємстві, підвищення рівня знань, що спричиняє збільшення обсягу людського капіталу.

Накопичення людського капіталу відбувається під час різних видів соціальних взаємодій, зокрема, через активну участь в організаціях неурядових та місцевих подій. Можливо вирахувати безпосередні витрати на ці фрорми діяльності та важко визначити, якою мірою вони є витратами на внутрішнє споживання. Крім того, важко відрізнити потоки цього капіталу від його стану. Певним здається тільки те, що величезний вплив на зростання людського капіталу має освіта, тобто, де-фракто освітня політика держави [61].

В сучасному суспільстві відповідальність, економічні витрати і ризики інвестицій в людський капітал перекладаються на саму людину. І, навіть, коли людина отримала середню, професійну чи вищу освіту, це не надає надійної гарантії для досягнення бажаного соціального статусу [61, с. 6]. За влучним висловом У.Бека, система освіти у сучасному суспільстві (в суспільстві ризиків) нагадує «примарний вокзал».

Поїзди вже не ходять за розписом або йдуть в іншому напрямі, 
вагони переповнені, але білети все рівно треба брати [2].

Освіта, звичайно, не втрачає свого значення, але їі результати $\epsilon$ непередбаченими і тому підлягають перегляду основних підходів, плануванню. В наш час прискорених глобалізаційних процесів гостро повстало питання освітнього експорту як нової форми економічних відносин. Основною мотивацією експорту освітніх послуг є отримання значних коштів і розвиток економіки.

Міжнародний ринок вищої освіти становить близько 100 млрд. доларів. За даними ЮНЕСКО, на світовому ринку освітніх послуг присутні вищі навчальні заклади понад 140 країн. За статистикою іноземний студент витрачає приблизно п'яту частину власних витрат в країні перебування на навчання, і чотири п'ятих - на проживання, харчування, розваги тощо. У США вища освіта - п'ята у грошовому обчисленні стаття експорту американської економіки, яка інколи перевищує обсяг надходжень від експорту зброї. В Австралії освітня галузь $є$ третім найбільшим джерелом бюджетних надходжень в економіку країни. У 2014 р. канадський уряд визнав міжнародну освіту ключовим фактором у створенні нових робочих місць та покращенні добробуту і планує до 2022 р. вдвічі збільшити кількість іноземних студентів - до 450 тис. осіб. Це призведе до зростання витрат іноземних студентів у країні до 16,1 млрд. доларів і дозволить створити в Канаді щонайменше 86,5 тис. нових робочих місць [45].

Протягом кількох років аналітичний центр CEDOS збирає та аналізує дані про кількість українських громадян, які навчаються у закордонних університетах [33]. Виходячи з теоретичної моделі інвестицій в людський капітал (міграція як частковий випадок, оскільки збільшує продуктивність людини) та на основі огляду літератури, аналітичний центр CEDOS доповнив існуючу базу даних змінними, які можуть визначати фактори, що впливають на рішення студентів мігрувати. Згідно моделі інвестицій в людський капітал під час прийняття рішення щодо еміграції особа порівнює вигоди від міграції з витратами пов'язаними з переїздом. Однак у випадку міграції студентів ця модель ускладнюється тим, що освіта також виступає інвестицією в людський капітал, оскільки зазвичай збільшує майбутній 
дохід. 3 огляду на дану залежність, студенти можуть їхати навчатись за кордон у двох випадках. По-перше, можливості для навчання вдома обмежені, але віддача від освіти вдома висока, тому вони здобувають бажану освіту й повертаються додому. По-друге, можливості для навчання вдома $€$, але віддача від освіти нижча, ніж в обраній країні, тому вони їдуть здобувати освіту за кордон 3 намірами там залишитись на постійне проживання.

Оцінка якості вищої освіти студентами була здійснена за ініціативи Фонду «Демократичної ініціативи», що відображено на рис. 3.3.

125 Висока 涳 Середн Се

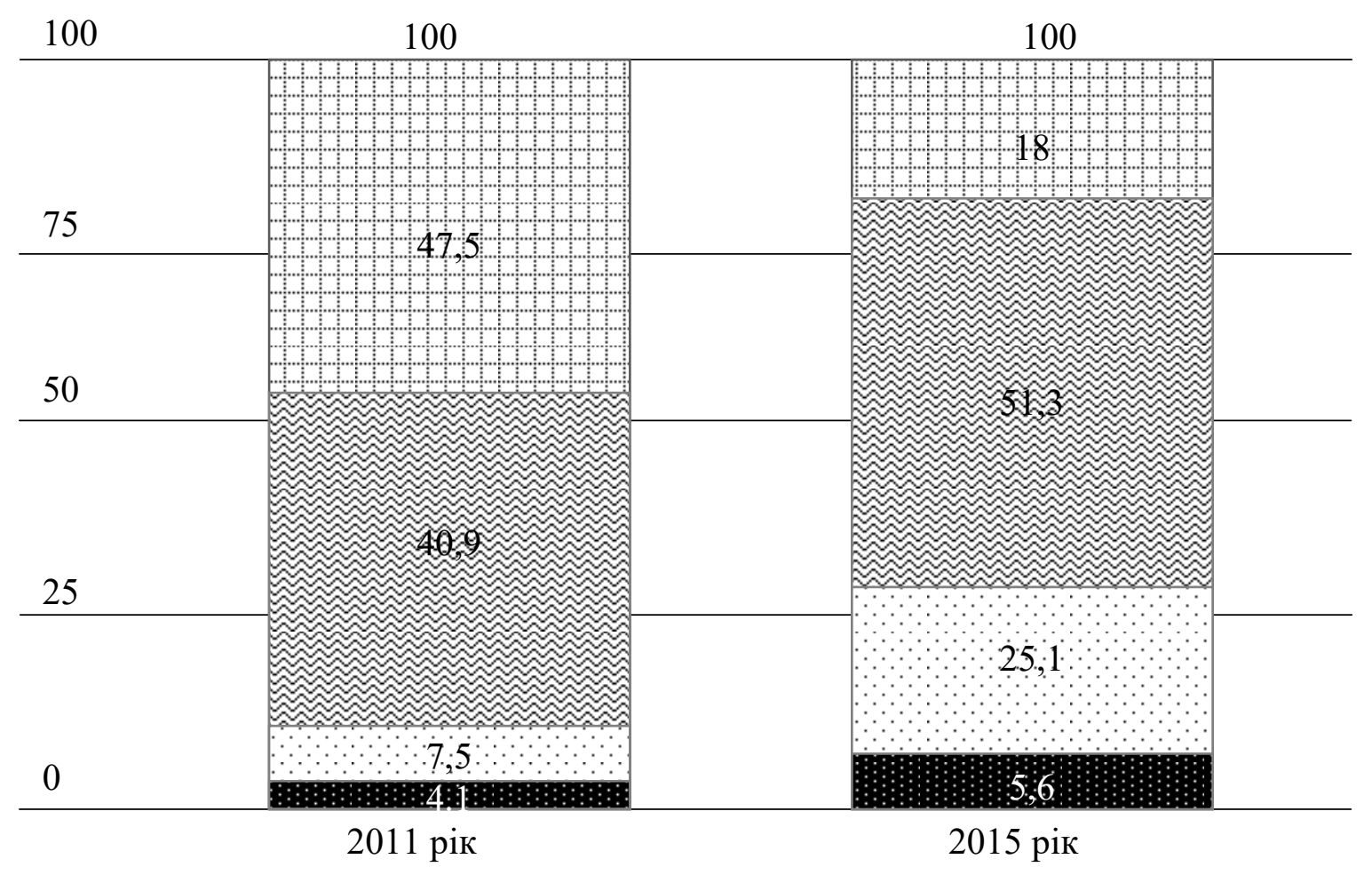

Рис. 3.3. Оцінка якості вищої освіти студентами [9]

Аналітичний центр CEDOS припустив, що більшість українських студентів, що навчаються за кордоном, мігрували саме з другої причини [18]. Їх припущення базуються на тому, що в Україні доступ до вищої освіти практично необмежений через суттєве державне замовлення і порівняно 
низьку вартість навчання на контрактній фрормі, а віддача від вищої освіти порівняно низька. Згідно з дослідженнями, кожен рік вищої освіти в середньому збільшував місячну заробітну плату на 5,6\%. Водночас віддача від освіти у Європейській Спілці була суттєво вища. У 2005 році у 28 країнах Європейської Спілки збільшення заробітної плати після здобуття вищої освіти в середньому складало 43\% (наприклад в Польщі - 45\%, Німеччині - 32\%, Чехії - 44\%) [33].

Результатом розвитку експорту освітніх послуг є все більш активне включення освітніх закладів в конкурентну боротьбу за залучення іноземних студентів. Так, наприклад, в Польщі останніми роками спостерігається безпрецедентне зростання кількості іноземних студентів. У 2016/17 навчальному році в країні навчалося 65793 іноземних студентів 3 166 країн, що більш ніж на 8,5 тисяч більше, ніж роком раніше (зростання більш ніж на 15\%) [33] (рис. 2).

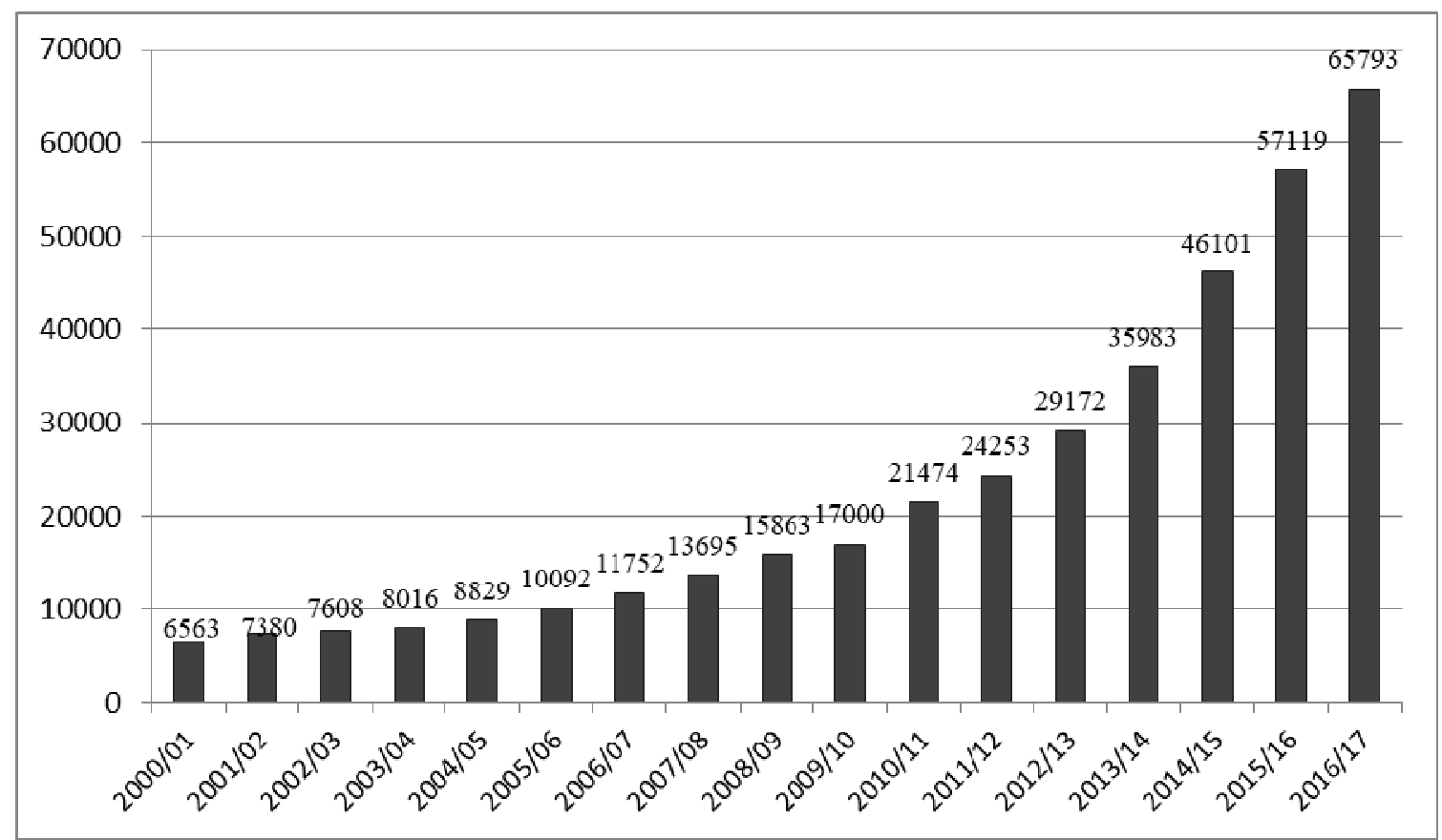

Рис. 3.2. Ріст кількості іноземних студентів по рокам у Польщі, осіб

Таке зростання кількості іноземних студентів спостерігається протягом періоду з 2005 року. В даний час іноземні студенти складають 4,88\% від загальної кількості студентів у Польщі (вісім років тому їх було всього 0,61\%, у 2015/2016 навчальному році - 4,07\%). Треба відзначити, 
що така тенденція зумовлена, головним чином, небувалим напливом студентів з України. За останніми даними GUS (Головне статистичне управління Польщі) в 2016-2017 навчальному році їх навчається 35584 осіб - тобто на 8,5 тисяч більше, ніж рік тому [33]. Вони становлять понад 54\% від загальної чисельності іноземних студентів в Польщі (рис. 3).

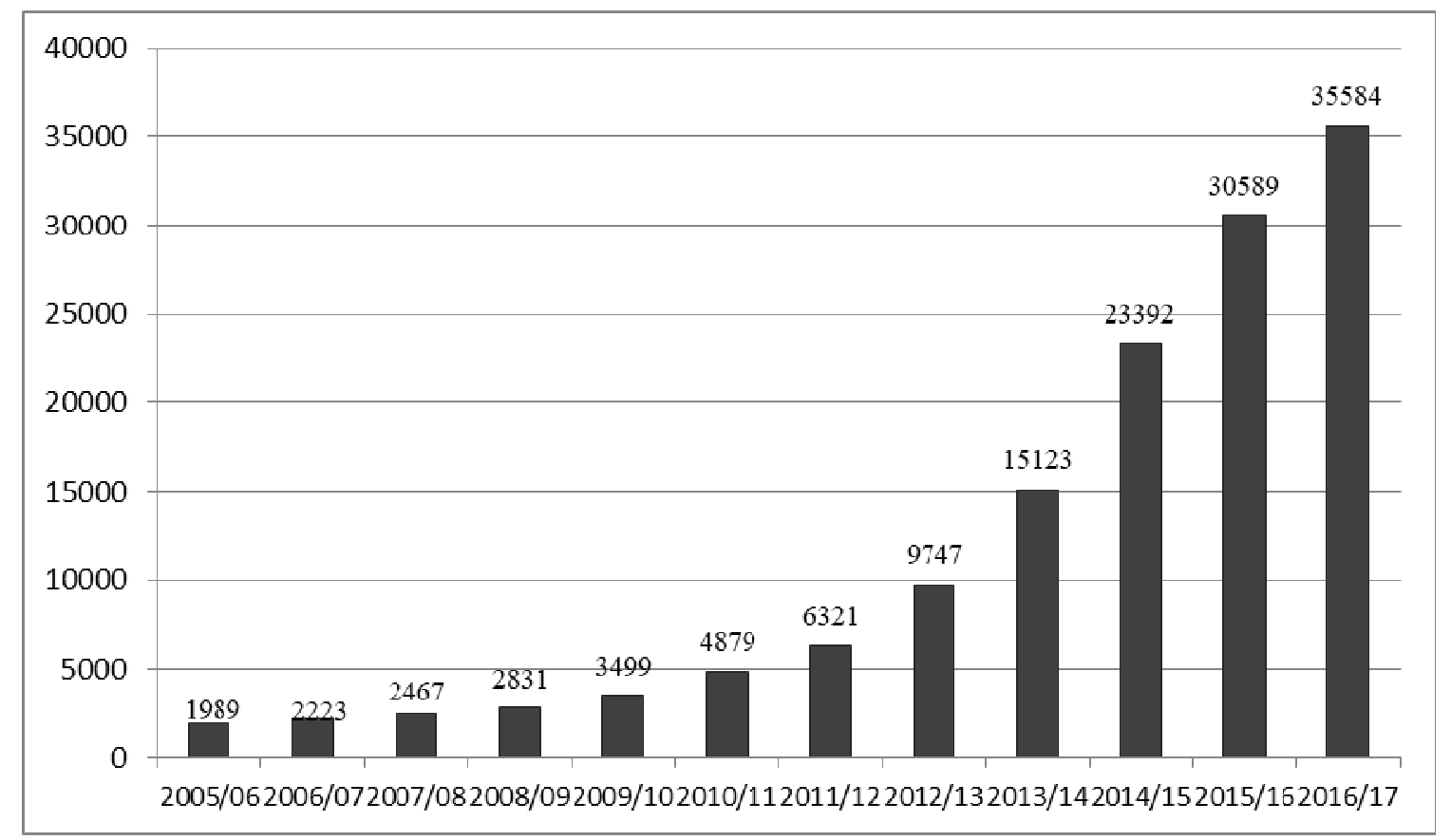

Рис. 3.3. Ріст кількості студентів з України в 2005-2017 роках

Цікаво зазначити, що на другому місці в даному рейтингу займають студенти з Білорусії, яких налічується 5119 осіб. Вони становлять 7,78\% від загальної кількості, що в 7 разів менше, ніж студентів з України. Стрибок зростання числа студентів з України зумовлений як послідовним, десятирічним стратегічним розвитком маркетингових і рекламних компаній польських вузів на цьому ринку (зокрема, в рамках програми «Study in Poland»), так і нинішньою складною політичною та економічною ситуацією в Україні, близькістю культур та мови.

Українські вищі навчальні заклади теж мають достатній потенціал для боротьби за частку міжнародного ринку освітніх послуг. За даними МОН України у 187 вищих навчальних закладах України здобувають освіту 65 тис. студентів зі 146 країн світу. Частка України на міжнародному ринку освіти за чисельністю іноземних студентів становить всього 1,5 \%. 
За останні роки кількість іноземних студентів значно збільшилась. Щорічні фрінансові надходження від них складають 4,3 млрд. грн. Вагомі надходження коштів мають вищі навчальні заклади, в яких навчається значна частка іноземних студентів. Надання освітніх послуг іноземним громадянам дозволяє забезпечити роботою 5 тис. викладачів.

Якщо взяти до уваги географрію іноземних вступників, то в Україні найбільше $(50 \%)$ навчається студентів з Азії: Туркменістану, Азербайджану, Китаю, Російської фредерації, Індії, Іраку, Ірану тощо. 3 африканського континенту чимало студентів приїздить з Нігерії. Понад 4 тис. іноземних студентів представляють європейські країни. Причиною того, що на навчання до України приїжджає мало іноземців з розвинутих країн, $€$ недостатньо високі котирування вітчизняних вищих навчальних закладів у міжнародних рейтингах, за якими визначається рівень якості освіти. У 2014 р. через події в Україні кількість студентів-іноземців зменшилася.

Моніторинг студентських уподобань свідчить, що вище всього на міжнародному ринку цінується бізнес-освіта. Майже $20 \%$ студентів вивчають технічні та інженерні науки, найпопулярніші з них - інформаційні технології. Приблизно стільки ж студентів обирають природничі науки. Замикає список медицина - 4-5 \%. Натомість в Україні 25 \% (понад 16 тис.) іноземних студентів опановує медичний фах. А $20 \%$ (понад 13 тис.) вивчають технічні науки. Гуманітарні та економічні факультети українських університетів користуються меншою популярністю серед іноземців.

Для української вищої освіти розширення експорту освітніх послуг вигідне, по-перше, з економічної точки зору: підготовка фахівців для зарубіжних країн стає однією з найбільш вигідних статей доходу, особливо в умовах слабкого фрінансування сфери освіти. По-друге, з точки зору підвищення якості освіти: прагнення залучити іноземних студентів спонукає українські заклади до формування системи підготовки фрахівців 3 урахуванням вимог світового ринку праці до якості освіти та напрямів підготовки фрахівців [46].

Інвестиції в людський капітал не обмежуються тільки освітою, хоча 
вважають її за основне джерело поповнення цього капіталу. Крім того, на якість людського капіталу в економіці впливають також інвестиції в поліпшення здоров'я, а також і в подовження життя. Особливо актуальні останній вид інвестицій в країнах третього світу, де голод, злидні і коротка тривалість життя населення різко обмежує можливості для розвитку.

Останніми роками в Україні все більше витрати на інвестиції в людський капітал покладаються безпосередньо на людей, носіїв цього капіталу, їх батьків, що утримують молодих людей, вкладаються у витрати на освіту в державних навчальних закладах, а також на все суспільство через систему фрінансування освіти. Ці інвестиції передбачають віддачу у вигляді майбутніх доходів, які перевищують вкладені кошти.

3 точки зору суспільства, повернення має полягати у майбутній більш високій продуктивності праці, більш високих доходах громадян, а, отже, і більш високих податках, що зумовлює економічний ефект від зроблених вкладень. Таким чином, ефективність розвитку національної економіки сучасної держави у величезній мірі залежить від того, скільки коштів вона інвестувала в освіту громадян. Без цього неможливо забезпечити їі поступовий економічний і соціальний розвиток.

\section{5. Формування інституту людського капіталу в Україні}

Формування і ефективне використання інституту людського капіталу для примноження багатства і потенціалу країни стає пріоритетом економічного розвитку. Залучення більш розвинутого людського капіталу національної економіки відіграє вагому роль у збільшенні прибутків власників бізнес-компаній, великих корпорацій і підприємств.

Визначений державою інноваційний вектор розвитку України спрямований на досягнення стабільно високих економічних показників як в загальних масштабах розвитку людського капіталу, так і на мікрорівні, для окремої конкретної людини [13]. Особливості сучасної ситуації України в господарській і політичних сферах обумовили певні зміни економічних відносин в країні. В Україні має місце правова неоднозначність у 
використанні людського капіталу, оскільки біля 40 \% зайнята в тіньовій економіці [52].

Людський капітал вважається найціннішим ресурсом країни, який створює перш за все інтелектуальний потенціал держави, що визначає її позиції на світовому полі. Наявність зрілого людського капіталу обумовлює економічний потенціал країни та її стратегічне зростання [3].

Питання використання та залучення людського капіталу національної економіки до праці, існування тіньового сектору економіки, а разом з ним тіньового ринку праці, упорядкування належним чином оформлених трудових договорів, що відповідають законодавству, постійно перебувають під увагою дослідників, роботодавців, державних контролюючих органів, законотворців, а також безпосередніх носіїв людського капіталу працівників.

В період нестабільності в нашій країні широко застосовуються незаконні методи збагачення. Збільшення власних накопичень - одна 3 провідних самомотивацій особистості до життєдіяльності, активного заробітку грошей [23]. Одним з методів незаконного збагачення власників бізнесових структур є залучення людського капіталу в тіньовий сектор економіки. Говорити про новизну цього сектору недоречно, але треба звернути увагу на його оновленість, застосування нових технологій і схем. В останні роки в Україні з боку держави значна увага приділяється врегулюванню національного ринку праці, соціальному розвитку людського капіталу національної економіки, відповідності українських законодавчих норм світовим стандартам, стандартам Євроспілки, загальнолюдським нормам; фокусування на проблемах окремої людини. В цьому плані спостерігається розвиток законодавчої бази України в сфері регулювання праці, ринку праці, трудових відносин, податкового законодавства в частині обкладання податками заробітної плати, пенсійного забезпечення, соціальної підтримки різноманітних верств населення.

Все це, з одного боку, сприяє ефективному використанню людського капіталу в економіці України. 3 іншого боку, обумовлює розвиток нових видів, схем залучення людського капіталу в національну економіку. 
Інтенсивний розвиток людського капіталу викликає необхідність його постійного вивчення, визначення ключових аспектів розвитку в специфічних умовах національної економіки. Людський капітал, як найбільш мобільний, з одного боку, і найбільш витратний, з іншого боку, ресурс і раніше широко залучався в тіньовий сектор економіки. Тому гостро постає необхідність вивчення причин залучення людського капіталу в тіньовий сектор економіки в існуючих умовах України, розробка методів протидії та ефективної боротьби з тіньовим залученням людського капіталу для нелегальної праці, в чому й полягає актуальність дослідження.

Практична значущість зазначеної проблеми зумовила мету та завдання дослідження. В рамках здійснення аналізу практики функціонування людського капіталу в Україні та розвинених країнах в дослідженні поставлено за мету вивчення причин використання людського капіталу національної економіки в тіньовому секторі в існуючих умовах України, розробка методів протидії та ефективної боротьби з тіньовим залученням людського капіталу національної економіки для нелегальної праці, що є одним із важливих аспектів використання людського капіталу на ринку праці.

Світовий досвід свідчить про існування двох складових ринку праці: відкритого ринку праці, де людський капітал використовується 3 дотриманням всіх мінімальних встановлених норм законодавства, та прихованого ринку праці, який використовує людський капітал без дотримання мінімальних гарантій в сфері праці (наприклад, це явища неповної фрормальної зайнятості в умовах простою). Крім того, кожна 3 складових поділяється на людський капітал, що залучений до офіційної частини ринку праці, та людський капітал, залучений до неофіційної частини ринку праці, та людський капітал, залучений до неофіційної частини ринку праці. Існує частина людського капіталу, що використовується в обох секторах. I Україна не є винятком у даному процесі.

Так звана «двоїстість» ринку праці породжує легальне і нелегальне використання людського капіталу національної економіки. Специфіка 
розвитку трудових відносин в Україні зумовила широке використання людського капіталу одночасно на легальному та нелегальному ринку праці (змішане використання людського капіталу).

Використання людського капіталу на ринку нелегальної праці має цілу низку причин. Це зв'язано, перш за все, 3 не розвиненим інституціональним середовищем у формі недосконалої податкової системи та загадьного низького рівня оплати праці, а також зі слабкою свідомістю роботодавців і найманих працівників - носіїв людського капіталу. Потрібно також відмітити прагнення роботодавців значно скоротити власні витрати за рахунок низької оплати праці.

Найпростіші економічні підрахунки витрат на людський капітал призводять до наступних результатів: з кожної виплаченої роботодавцем найманому працівнику однієї тисячі гривень («чистими») потрібно сплатити до бюджету та пенсійного фронду 515,53 грн. податків та внесків (з них 223,60 грн. - податок на доходи фрізичних осіб - 18\%, 18,64 грн. військовий збір - 1,5\%, 273,29 грн. - єдиний соціальний внесок). В цілому податки та обовязкові внески на оплату праці людському капіталу складають 51,6\%. Якщо враховувати міжнародний досвід, це середній показник відсотків податків на зарплату в світі. Так, в країнах 3 високорозвинутою економікою, наприклад, в Фінляндії, платники податків відраховують до 70 \% податків з заробітної плати.

3 одного боку, потрібно відмітити позитивні сторони легального отримання доходів для працівника. По-перше, працівник прийнятий на роботу, про що надається повідомлення до Пенсійного фонду України. В данному випадку період роботи на підприємстві працівника, коли він отримував заробітну плату та здійснював єдиний соціальний внесок до Пенсійного фонду (через податкового агента - підприємства) зараховується в його страховий стаж. Отже, такий стаж враховується при обчисленні пенсії - за умови сплати мінімального єдиного соціального внеску. Якщо єдиний соціальний внесок за розміром менше мінімального страховий стаж враховується пропорційно сплаченому внеску. При цьому працівник має можливість доплатити єдиний страховий внесок до 
мінімального для врахування страхового стажу як повний.

По-друге, правова держава гарантує забезпечення мінімальних гарантій при залученні людського капіталу в економіку України. Так, легальне працевлаштування гарантує працівнику затверджений державою рівень мінімальної заробітної плати, мінімальний єдиний соціальний внесок до Пенсійного фонду України [13]. I з огляду на те, що соціальні стандарти поступово підвищуються в Україні, держава прогнозує доведення мінімальних норм до європейського рівня. Дане положення зумовлює стабільність та деякий рівень впевненості в майбутньому для людського капіталу.

По-третє, легальне працевлаштування означає для працівника гарантію отримання виплат у разі хвороби по листку непрацездатності.

По-четверте, працівник при відповідному законодавству працевлаштуванні отримує від підприємства соціальний пакет послуг, що включає поряд з базовими складовими, що відповідають, зазвичай, мінімальним передбаченим законодавством про працю та соціальне забезпечення гарантіям, додаткові визначені роботодавцем пільги та умови. Повноцінно сорормований на підприємстві соціальний пакет послуг не тільки фрормує позитивний імідж роботодавця, але й, в першу чергу, захищає працівника та стимулює його до відповідального ставлення до праці, повноцінне виконання трудових обов'язків, вкладання накопиченого людського капіталу в створення нового продукту.

По-п'яте, до позитивних сторін легального працевлаштування можна віднести можливість підвищувати рівень власної професійної майстерності шляхом навчання, перенавчання, підвищення кваліфікації, взагалі формування освітнього капіталу $[14 ; 18]$ як складової людського капіталу за допомогою роботодавця.

В Україні на протязі останніх десяти років набирає обертів розуміння роботодавцем важливості вкладень в людський капітал. Знайшла своїх прихильників концепція корпоративної соціальної відповідальності, що передбачає для роботодавця не обмежуватися в забезпеченні працівників мінімально встановлених законодавством гарантій, а орієнтуватися на 
інвестиції в людський капітал та взаємний контакт з учасниками процесу праці та виробництва. Така стратегія по відношенню до людського капіталу стає підґрунтям не тільки для розвитку людського капіталу, але й до комерційного успіху бізнесу через його соціальну відповідальність.

3 іншого боку, в ряді причин нелегального залучення капіталу, у тому числі людського, в економіку України, треба розглянути спонукальні мотиви небажання українських працівників офріційно працевлаштовуватися. Лейтмотивом вважаємо матеріальну мотивація працівника. Роботодавець у разі виплати неофіційної заробітної плати, економить на невиплаті податків 51,6\% (як було розраховано вище в дослідженні). 3 вказаної суми він може запропонувати деяке підвищення оплати праці робітнику. Але моніторинг ринку праці та практичний досвід демонструє наступні результати. Найчастіше людський капітал - працівник - поставлений в достатньо жорсткі умови працевлаштування. За даними міністерства фрінансів України рівень безробіття за перший квартал 2017 року в Україні склав 10,5 \%, за другий квартал 2017 року - 10,0\% [48]. Аналізований показник в 2016 році складав 9,7\%, за 2015 рік - 9,5\%, в 2014 році дорівнював рівню 2016 року 9,7\% [48]. За даними офіційної статистики та міністерства фінансів України кількість зареєстрованих безробітних в країні в 2017 році складає 393,7 тисяч осіб [48]. В той же час, за оцінками експертів офіційна статистика надає далеку від реальних фактів картину. За їх висновками, реальний рівень безробіття в Україні складає біля 25\% з урахуванням прихованого безробіття, яке втілено в неповній зайнятості працівників - неповний робочий тиждень, неповний робочий день [29]. Роботодавець за цією ситуацією має змогу диктувати вимоги до працівника: чітко обумовлений рівень заробітної плати, зверхнормативний режим робочого дня, неоплата днів хвороби, залучення до праці без оформлення трудових відносин. При цьому, якщо працівника або майбутнього працівника не влаштовують вимоги роботодавця - ніхто його не утримує та не умовляє працювати на даному підприємстві.

До витоків залучення людського капіталу в тіньовий сектор економіки нашої країни можемо віднести низький рівень заробітної плати в 
офріційному секторі ринку праці, що змушує населення працювати додатково в тіньовому секторі; низький рівень доходів населення, яке спроможне купувати в більшості дешеву продукцію, вироблену в тіньовому секторі за низькою собівартістю; високий рівень безробіття і як наслідок готовність людського капіталу працювати будь-де на будь-яких умовах; зростання рівня безробіття, в умовах якого офріційно працюючі підприємства не можуть забезпечити роботою всіх бажаючих, а соціальна підтримка непрацюючих відсутня, або слабка; відсутність дієвого механізму соціального захисту та пенсійного забезпечення людського капіталу, який стимулював би людський капітал продавати себе та позиціонуватися на ринку праці виключно в законному секторі; існування незахищених та слабозахищених верств населення, які мають обмежені можливості працевлаштування і неконкурентноздібні на законному ринку праці; недосконалість українського законодавства. Всі ці фрактори позитивно стимулюють залучення людського капіталу в тіньовий сектор економіки України.

Інше заінтересоване джерело, що сприяє залученню людського капіталу в тіньову сферу виробництва, надання послуг, виконання робіт це український роботодавець. Його мета - отримання якнайбільшого підприємницького прибутку. В умовах скорочення споживання товарів у зв'язку 3 низькою купівельною спроможністю населення, а отже неможливістю підвищення доходів, єдиний вихід для отримання розвитку прибутку - скорочення витрат по всім складовим та елементам.

Серед методів протидії та ефективної боротьби з тіньовим залученням людського капіталу для нелегальної праці вважаємо актуальними розробку, формування належної законодавчої бази регулювання використання людського капіталу на національному ринку праці.

Держава як безпосередній та прямий отримувач доходів, що надходять у виді податків та внесків, заінтересована в підвищенні доходів населення та доброчесному висвітленні видатків на утримання людського капіталу на підприємствах роботодавцями. В цьому напряму з першого 
січня 2017 року в Україні на законодавчому рівні посилена відповідальність керівників роботодавців всіх рівнів залучення людського капіталу в економіку країни: підприємців, закладів, установ, організацій, підприємств всіх галузей народного господарства, органів державної влади, органів місцевого самоврядування за порушення діючих норм в сфері праці та її оплати [12]. Введеним в дію законом підвищені штрафи за ряд порушень трудового законодавства. Їх розмір складає від 3200,00 гривень до 320 тисяч гривень. Для вищеозначеного сектору суб'єктів, до яких можуть бути застосовані такі санкції, особливо для малих та середніх платників податків, це значні суми витрат. Тому, гадаємо, всі без винятку роботодавці будуть цілком відповідально ставитися до оформлення трудових відносин 3 працівником, зважаючи на суму існуючих штрафрів.

Ефективним методом протидії нелегальному працевлаштуванню в Україні може стати система державного медичного страхування, яка забезпечить працівника мінімальними гарантіями за принципами накопичувальної, а не солідарної системи. Підвищення рівня державних гарантій у сорері оплати праці, створення народних (соціальних) контрольних органів за дотриманням законодавства в сфері праці дозволять вилучити значну частину людського капіталу з нелегального сектору ринку праці. Створення нових робочих місць, значне обмеження відтоку людського капіталу з України до інших країн шляхом державного регулювання, активізація діяльності державних контролюючих органів за сферою трудових відносин - це традиційні методи боротьби з тіньовим залученням людського капіталу для нелегальної праці.

Проведене дослідження використання людського капіталу національної економіки на ринку праці України надало можливість зробити наступні висновки.

Ефективне використання людського капіталу національної економіки для примноження багатства країни у передових світових держав стає пріоритетом розвитку. Особливості ринку праці породжує легальне використання людського капіталу національної економіки, нелегальне використання людського капіталу національної економіки, змішане 
використання людського капіталу.

Серед глибинних причин використання людського капіталу національної економіки в тіньовому секторі в існуючих умовах України, виявлено наступні: низька свідомість як роботодавців, так і самих осіб носіїв людського капіталу; прагнення роботодавців значно скоротити власні витрати на високоякісний та профеесіональний або ж некваліфікований людський капітал; матеріальну мотивація працівника підвищення рівня неофіційної оплати праці порівняно з рівнем офіційної зарплати за рахунок неутримання податків; низький рівень доходів населення, яке спроможне купувати в більшості дешеву продукцію, вироблену в тіньовому секторі за низькою собівартістю; високий рівень безробіття і як наслідок - готовність людського капіталу працювати будь-де на будь-яких умовах; зростання рівня безробіття, в умовах якого офіційно працюючі підприємства не можуть забезпечити роботою всіх бажаючих, а соціальна підтримка непрацюючих відсутня, або слабка; відсутність дієвого механізму соціального захисту та пенсійного забезпечення людського капіталу, який стимулював би людський капітал продавати себе та позиціонуватися на ринку праці виключно в законному секторі; існування незахищених та малозахищених верств населення, які мають обмежені можливості працевлаштування і неконкурентноздібні на законному ринку праці; недосконалість українського законодавства. Всі ці фрактори позитивно стимулюють залучення людського капіталу в тіньовий сектор економіки України.

Серед традиційних методів боротьби з тіньовим залученням людського капіталу для нелегальної праці вважаються створення нових робочих місць, значне обмеження відтоку людського капіталу з України до інших країн шляхом державного регулювання, активізація діяльності державних контролюючих органів за сферою трудових відносин.

Ефективними методами протидії нелегальному працевлаштуванню в Україні може стати система державного медичного страхування, підвищення рівня державних гарантій у сфері оплати праці, створення народних (соціальних) контрольних органів за дотриманням законодавства 
про працю.

Подальші дослідження використання людського капіталу національної економіки на ринку праці України заплановано спрямувати на оцінку вартості використання людського капіталу на різних сегментах ринку праці.

\section{6. Людський капітал як чинник конкурентоспроможності} національної економіки

Зміна політичних, економічних і соціальних умов в державі призвели до корінних змін в Україні, які торкнулися і сфери трудових відносин. При цьому ослаблення державного контролю за дотриманням норм трудового законодавства, правовий безлад привели до вкрай негативних наслідків. Звичайним явищем стало порушення трудових прав працівників в оплаті, безпеки праці. Збільшилося число незаконних звільнень, почастішали випадки неукладання трудових контрактів, затримки виплати заробітної плати. Так, заборгованість із зарплати становила на 1.04.2008 р. 692,4млн. грн. Із загального обсягу заборгованості майже 59,2\% припадає на економічно неактивні підприємства та підприємства - банкрути, тобто виплата цих сум незабаром не передбачається.

Майже 90\% роботодавців України порушують законодавство про працю [25]. Про це свідчать перевірки, проведені державними інспекціями праці. Тому існує потреба знаходження наукового підґрунтя і створення механізмів реального захисту трудових прав громадян,зміни інституціонального підґрунтя розвитку соціально-трудових відносин.

Сучасний стан соціально - економічних відносин в Україні за останнє десятиліття можна охарактеризувати наступними рисами:

- тінізація соціально-трудових відносин, де спостерігається найбільша кількість порушень і повністю відсутній контроль за дотриманням трудового законодавства. Приховування підприємствами трудових відносин стало головною проблемою періоду ринкової економіки в Україні. Це призводить до виплати зарплати «в конвертах», відповідно несплаті всіх обов'язкових 
страхових і пенсійних зборів. Що в свою чергу тягне за ст.46 Конституції України порушення прав громадян на соціальний захист - позбавляє працівника допомоги по тимчасовій непрацездатності, допомоги по безробіттю, пенсії та інших соціальних виплат.

Шляхом неформальних трудових відносин працівник отримує більш високий дохід за свою працю (не сплачуючи податки), але позбавляє себе конституційних прав і гарантій і, відповідно, захисту;

- високий рівень прихованого і часткового безробіття, яка властива підприємствам, які мають економічні проблеми. Вони відправляють працівників у адміністративні та вимушені відпустки за свій рахунок без збереження заробітної плати;

- відсутність контролюючих органів або невиконання ними контрольних функцій за дотриманням трудових прав працівника на всіх рівнях (на підприємстві, в муніципалітеті, державі);

- непрозорість трудових відносин на підприємстві;

- розширення неформальних безконтрактних форм найму і оплати праці і на цій підставі повне порушення трудових прав працівників;

- прихований саботаж працівників як зміна тактики перешкоджання роботодавцям замість відкритих конфліктів (страйків, судових процесів), який призводить до непродуктивного виконання трудових функцій;

- трудова еміграція за кордон і незахищеність прав українських трудових мігрантів. За оцінками експертів нині за кордоном працює до 4,5 млн. Громадян України (в країнах ЄС, США, Російської Федерації). Тільки в Росії перебувають на заробітках понад 2 млн. Наших громадян, в США і Італії - 500 тис., Польщі - понад 450 тис., Чехії - 150 тис. [20];

- негативний вплив традиційної культури праці та особливостей попередніх соціально-трудових відносин на впровадження інноваційних методів управління;

- необмежений монополізм роботодавців на ринку праці, відсутність конкуренції в боротьбі за потенційного працівника і зв'язані 3 цим протиправні дії роботодавців щодо найманих працівників;

- незнання працівниками трудового законодавства, своїх прав у сфері 
праці.

Таким чином, для України характерні масові порушення економічних інтересів (невиплата, затримка зарплати) і соціально-трудових прав працівників.

Однією з головних причин, яка зумовила негативні процеси в сфері соціально-трудових відносин, охорони, умов і безпеки праці $\epsilon$ те, що масштабні зміни в останні роки в Україні не супроводжуються комплексним підходом до реформування і впровадження нових форм і методів управління і єдиної національної політики в сфері праці. Як свідчить світовий досвід, реформування в країні має здійснюватися в усіх напрямках одночасно і планомірно.

Сприяють процвітанню порушень фрінансові труднощі підприємств, політична нестабільність, недостатній рівень знань законодавства про працю роботодавцями, високий рівень оподаткування зарплати.

В останні роки в Україні прийнято багато директивних документів, де захист прав людини і його трудових прав визначені як основна стратегічна мета держави, на досягнення якої повинні бути спрямовані зусилля органів державної влади, правоохоронних органів, роботодавця

Однак дотепер більшість працівників залишаються за межі-цями правового поля, нормативних та регуляторних актів, які покликані захищати їх права. Внаслідок цього значно віз-розтане кількість людей, які не мають постійної зайнятості, працюють по неформальним договорами. Це одна 3 ключових проблем в контексті забезпечення гідної праці для всіх - так як чим більше працівників працює за неформальними угодами, тим більше вони потерпають від порушень своїх прав.

Глибокі розбіжності в економічному становищі, трудовій поведінці, рівні освіти і культури роботодавців та працівників визначають суттєві особливості в ступеня зрілості трудових відносин. Перш за все найманий працівник повинен бути готовий і здатний до особистого активної участі в колективній захисту своїх інтересів в процесі формування та регулювання трудових відносин, мати певну установку на ті чи інші способи участі в цій діяльності. Те ж саме стосується роботодавця. Його активність і 
самоповагу не повинні дозволяти йому застосовувати форми праці, що не відповідають міжнародним нормам і українським законодавством.

Більш детального уваги вимагає також роль держави, як суб'єкта соціально-трудових відносин. Правова держава обмежена в своїх діях законодавством, яке захищає свободу, безпеку гідність особистості і підпорядковує владу волі суверенного народу. Соціальна держава разом із правовими принципами має забезпечити також кожному громадянину гідні умови життя, соціальну захищеність, співучасть в управлінні виробництвом.

Тому підготувати працівника до захисту своїх прав перед роботодавцем, роз'яснити його права .і рівні захисту вважаємо необхідною умовою захисту трудових прав працівника на підприємстві.

На етапі впровадження Нового Кодексу законів про працю в Україні доцільно розробити механізм максимальної реалізації людиною своїх прав і свобод, зокрема права на працю.

Шляхи захисту трудових прав працівника на підприємстві полягають у наступному:

- рефрормування трудового законодавства:

- підвищення відповідальності за порушення трудових прав працівника;

- створення законодавчої бази для передчасного виходу на пенсію;

- впровадження програм активізації служб зайнятості;

- розробка механізмів легалізації зарплати;

- зниження податкового навантаження на фонд зарплати;

- перерозподіл страхових внесків між працівниками і роботодавцем;

- захист соціально незахищених верств населення (інвалідів, сиріт, багатодітних);

- формування рівних можливостей у трудовій сфрері, що спрямоване на усунення дискримінації та нерівності між чоловіками і жінками, сприяння працевлаштуванню всіх верств населення (молодь, жінки, інвалідів, сільське населення);

- створення спеціалізованих судів для розгляду трудових спорів та удосконалення судової системи в частині розгляду трудових спорів; 
- детінізація трудових міграцій з метою захисту соціальних і трудових прав громадян країни, які працюють за кордоном;

- укладення двосторонніх міжнародних договорів з іншими країнами в сорері працевлаштування для вирішення проблем легального працевлаштування громадян України на території інших країн і забезпечення їх прав і захисту. На сьогоднішній день укладено 11 таких договорів, активні переговори ведуться з Іспанією, Італією, Грузією, Естонією;

- роз'яснення працівникам їх прав;

- ведення індивідуальної роз'яснювальної роботи.

Таким чином, роботодавці України не дотримуються трудового законодавства, що призводить до значних порушень трудових прав громадян. Поряд з позитивними тенденціями, сучасний стан соціальнотрудових відносин характеризується високим рівнем тінізації економіки. Серед причин такого становища можна назвати фінансові труднощі підприємств, політична нестабільність, недостатній рівень знань роботодавцями законодавства про працю, високий рівень оподаткування зарплати.

Жорстке конкурентне середовище ставить високі вимоги до людського капіталу, який позиціонується на ринку виробників товарів і послуг. У цих умовах, виробник має залучити такі ресурси, які зможуть створити йому затребувані товари, послуги, роботи.

Саме ці позиції спричинили підвищення роботодавцями вимог до конкурентоспроможності людського капіталу. Професійні знання та навички, ретельність, ініціативність і комунікативність, наявність вмінь практичного вирішення проблем, використання технічних засобів, доступ до інформації, інтелектуальний потенціал, креативність - це далеко не весь перелік особистісних якостей людського капіталу, потрібних роботодавцю. Крім того, важливою характеристикою людського капіталу стає вміння застосовувати свої знання і широкий світогляд під час виконання роботи.

Це викликає потребу в підготовці конкурентоспроможного людського капіталу на ринку праці. Перспективність вкладень в людський капітал дає 
можливість забезпечити підвищення його конкурентоспроможності в майбутньому і, як наслідок, - більш високу ефективність його віддачі.

Г. Беккер вважав, що людський капітал це певний запас знань, навичок, мотивацій [24]. Нагромадження запасу знань, навичок, здібностей, мотивацій є підставою для розвитку конкурентних відносин між носіями людського капіталу, що забезпечило їх певними конкурентними перевагами і конкурентоспроможністю. Розвиток конкурентоспроможності людського капіталу є ключовим фактором для зростання економіки.

Інвестиції в людський капітал деякі дослідники вважають найбільш перспективними [1; 7; 17; 24]. При цьому виділяють декілька важливих напрямків вкладень - в виховання, освіту, здоров'я, знання, розвиток підприємливості, культури, етики, заняття мистецтвами. Серед них базисними, очевидно, виступають виховання і освіта.

Підвищення інвестиційної активності бізнесу шляхом вкладення коштів в нові технології та обладнання зумовлює потребу в людському капіталі з новими знаннями, навичками, вміннями, тобто з більш високою конкурентоспроможністю. Це, в свою чергу, висуває нові вимоги до такої складової людського капіталу, як освіта.

Вкладення в людський капітал в період ринкового розвитку економіки вважаються новим інструментом для вимірювання соціально-економічного прогресу держави та потенціалу як благополучних, так і країн, що розвиваються [7].

Вкладення в людський капітал спрямовані на формування і розвиток його можливостей. Ефективність вкладень залежить від відповідності напрямків вкладень особистісним інтересам носія людського капіталу для продуктивної його діяльності та відповідності потребам суспільства. При цьому вважається, що людський капітал $€$ важливою фрормою кінцевих капіталовкладень суспільства, що визначають динаміку і рівень життя не тільки країни, а й світової спільноти в цілому [17].

У структурі вкладень в людський капітал можливо виділити наступні складові: вкладення у виховання, в початкову освіту, в професійну освіту, у вищу освіту, перепідготовку, підвищення кваліфікації, вкладення в 
здоровий спосібжиття, в відпочинок, вкладення в спорт, в заняття мистецтвом, в розвиток творчих здібностей, в розвиток вроджених здібностей і якостей, у здоров'ї, в наукову діяльність, у зовнішній вигляд. При чому вкладення по різних складових повинні бути збалансованими. Надання істотних переваг за окремими складовими викликає диспропорції у розвитку людського капіталу товариства.

Не всі вкладення або не в повному обсязі вимагають матеріальних витрат. Можуть бути витрати фрізичні (в здоровий спосіб життя, в спорт), емоційні (в здоровий спосіб життя, в заняття мистецтвом), психологічні, тобто нематеріальні витрати, які вимагають вкладень інших ресурсів. Інвестор в людський капітал може бути як зовнішній (сім'я, підприємство, муніципалітет, держава, міжнародні фонди), так і сам носій людського капіталу.

Величина вкладень в людський капітал залежить від ряду фракторів. У їх сукупності можна виділити об'єктивні (вік, стать, зовнішній вигляд, антропометричні дані, стан здоров'я) і суб'єктивні (наприклад, психологічні). Вкладення в людський капітал - в частині матеріальних витрат, виражених в грошовому еквіваленті - широко використовуються в методиках оцінки людського капіталу $[1 ; 7]$.

Таким чином, питання конкурентоспроможності людського капіталу набуває все більшої актуальності, оскільки є об'єктивною умовою розвитку економіки країни і забезпечує їй не тільки додаткові конкурентні переваги, але і в цілому підйом і процвітання. Тому необхідне вироблення механізмів формування та розвитку конкурентоспроможності людського капіталу 3 урахуванням постійного прогресу суспільства. Механізми повинні бути динамічними. Для забезпечення розвитку конкурентоспроможності людського капіталу важливо розробити таку систему конкретних заходів, які включають сукупність певних елементів, в результаті взаємодії яких забезпечується розвиток конкурентоспроможності людського капіталу.

Вкладення в людський капітал, як матеріальні, так і нематеріальні (фізичні, психологічні, емоційні) забезпечують підвищення його конкурентоспроможності на ринку праці. 


\section{7. Вкладення в людський капітал - дієвий засіб підвищення} його конкурентоспроможності

Формування конкурентоспроможного людського капіталу підприємства залежить від ряду чинників. 3 позицій інституціональної економічної теорії різноманітні інститути діють на поведінку економічних агентів, стають основою мотивації поведінки та важелями впливу на рішення економічних агентів. Інституціональний розвиток суспільства слід розглядати як тривалий процес взаємодії складових інституціонального середовища, складових неінституціонального середовища, а також враховувати усі впливи та дії в економіці [38].

Також, людський капітал є надійним підґрунтям, базою розвитку держави - соціального, економічного, політичного [63]. Застосування конкурентоспроможного людського капіталу - необхідність за умов конкуренції підприємств на ринку. Конкурентоспроможність людського капіталу має стати об'єктивною умовою розвитку підприємства. Висока конкурентоспроможність людського капіталу забезпечує конкурентоспроможність підприємства.

Виходячи з вищенаведеного, при аналізі конкурентоспроможності людського капіталу важливо дослідити, які саме інститути впливають на конкурентоспроможність людського капіталу, зміст впливу, його вагомість, можливість регулювання при необхідності.

Інститути певним чином регламентують взаємодію суб'єктів господарювання та в їх складі людського капіталу. За визначенням Д. Норта, інститути - це сукупність правил або норм , та механізмів їх реалізації. Вищенаведена теза та аналіз ситуації на промислових підприємствах дали змогу зробити наступні висновки: вплив економічних інститутів на людський капітал підприємства та його конкурентоспроможність має регулюючий характер; зворотна дія складається в формуванні самим людським капіталом певних правил, обмежень. Останнє стосується у більшості випадків неформальних інститутів. 
В дослідженні фракторів, що впливають на розвиток конкурентоспроможності людського капіталу підприємств, науковці виділяють науково-технічні, організаційно-економічні, соціально-економічні, демографічні та культурні. Їх аналіз дозволяє зробити висновок про присутність значної долі інститутів в одних групах фракторів або про наявність невеликої інституційної складової по інших групах. Кожний 3 наведених фракторів можливо визначити як окремий інститут, що впливає на формування конкурентоспроможності людського капіталу. Вплив науково-технічних факторів в значній мірі зумовлений дією законів та нормативних актів, що стримують або сприяють розвитку. В складі організаційно-економічних факторів виділяють господарські зв'язки, що зумовлені також дією певних інститутів. По групі соціально-економічних та демографічних фракторів інституціональний вплив визначається соціальнопсихологічним кліматом в колективі та країні, політикою держави.

Визначальну роль у формуванні конкурентоспроможності людського капіталу відіграють такі економічні інститути як біржа праці, служби зайнятості, пенсійні, страхові фонди, законодавство як визначальна складова політичних інститутів, вищі навчальні заклади та система середньої освіти в інституціонально-технологічній підсистемі. Якщо модель досягнення певного ступеню конкурентоспроможності людського капіталу представити у вигляді сходів, високий освітній рівень стає початковою сходинкою. Долаючи кожну наступну сходинку, людський капітал підвищує свій рівень конкурентоспроможності, і таким чином, забезпечує себе якісним робочим місцем з високою зарплатнею.

Законодавство стає головним регламентуючим та нормоутворюючим інститутом, що впливає на конкурентоспроможність людського капіталу. Дія обмежень та правил дозволяє регулювати конкуренцію між підприємствами, обмежувати монополію та монопсонію на ринку праці. Разом з тим, саме цей фактор допомагає розвиватися доброчесній конкуренції на ринку товарів, послуг, робіт.

Біржа праці відіграє роль середовища, в якому кожна особистість людського капіталу має можливість співставити власну 
конкурентоспроможність 3 конкурентоспроможністю інших суб'єктів, проаналізувати потреби та нові тенденції ринка праці. Неабияку роль тут відіграють центри зайнятості, за допомогою яких індивідуум може змінити фах, підвищити рівень освіти, перекваліфікуватися.

Використання інституціонального підходу при аналізі впливу інститутів на конкурентоспроможність людського капіталу допомагає виявити в різних інституціональних умовах вплив інститутів на підвищення людським капіталом своєї конкурентоспроможності, механізм конкуренції в рамках самих інститутів. Всебічний аналіз допомагає дослідити ступінь розвиненості інституціональних умов для фрормування та підвищення конкурентоздатності людського капіталу підприємств.

Дослідники відзначають, що період розвитку ринкових відносин в Україні характеризується недостатньою розвиненістю ринкових інститутів. Даний фактор ускладнює не тільки вивчення зв'язків та взаємного впливу інститутів та економічних агентів, а також зумовлює постійну динаміку цих відносин. Крім того, фрормування інституціонально-ринкової структури економічної системи України обумовлено наявністю суперечок між формальними та неформальними інститутами та наявністю тіньового сектора економіки.

Означені фактори обумовлюють необхідність досконального вивчення взаємодії інститутів та конкурентоспроможності людського капіталу підприємств. 


\section{РОЗдІЛ 4}

\section{ІНСТИТУЦІОНАЛЬНА ТРАНСФОРМАЦІЯ ЕКОНОМІЧНОЇ БЕЗПЕКИ}

\section{1. Зміна інституціональної парадигми економічної безпеки}

Інституціональна зміна парадигми - це перелом сприйняття ролі і значення соціальних, політичних, економічних, військових чи релігійних інститутів. Це зміна способу мислення і дії, заснованої на раціональності, що об'єднує безпеку з механізмами наказів і контролю. Бо ні одна традиційна фрорма суспільної думки не може відповісти на питання про необхідність і межи втручання в разі надзвичайної ситуації. В цьому випадку завжди виникає небезпека тоталітаризму і гегемонії у всіх фрормах. У сучасному плюралістичному і різноманітному світі потрібне мислення, яке здатне формулювати та усувати причини використання засобів сили, а на їх місце мають прийти політичні і моральні ресурси.

Традиційним і найбільш поширеним підходом, який стосується ролі сили у житті суспільства, є положення про те, що завдання держави це, перш за все, реалізація цілей безпеки інститутів і інституцій суспільства, загроз там, де не має закону і порядку. Це означає, що при досягненні безпеки держава обмежується широко трактованими поняттями внутрішньої і зовнішньої безпеки. Гарантією останніх вважається накопичення сили тому, що причиною хаосу і анархії в окремих країнах і в міжнародних відносинах $€$ ії дефіцит. В результаті цього багатьма дослідниками сформульована теза про те, що у світі конкуренції i суперництва не можливо уникнути насильства.

Багато авторів, які прагнуть бути реалістами виходять з того, що безпеки не має там, де справа дійшла до загрози для держави і народ. Окрім того там, де всередині суспільства, в міжнародних відносинах (де живуть різні національності, що розділені кордонами) і в окремих країнах (де в одній державі живуть різні національності) не діє не мораль, там переважає насильство. Очевидно, безпеки не може бути гарантовано 
тільки силою (держав, коаліції держав), а лише через довіру у внутрішніх та міжнародних відносинах, тобто на підставі моральних засад. Якщо контакти окремих людей і держав будуть засновані на універсальних інститутах, тобто, моральних принципах, то виникне порядок у внутрішніх і зовнішніх зв'язках, що створюють умови для загальної безпеки людства.

Наведені міркування показують, що принципово нове рішення можливе тільки на основі інституціональної парадигми, що включає реальний плюралізм цілей і рішень (у тому числі ідей, ідеалів, цінностей, норм, політичних і соціальних систем і т.д.) i, як наслідок, відкриття місця для толерантності, важливості діалогу, досягнення компромісу і консенсусу.

Становлення парадигми нової інституціональної економіки $\epsilon$ процесом, який охопив погляди провідних неоінституціоналістів, що спиралися на думки і систему понять засновника інституціоналізму Т. Веблена. Який вважав, що її завданням, в першу чергу, було створення концепції, соціально-економічної системи, представленої як сукупності різних інститутів [33, с. 80]:

- корисних, тобто таких, що пов'язані з світом промисловості, в якому працівники в бажанні отримати хорошу роботу, здійснюють процес виробництва;

- а також непродуктивних, тобто тих, які пов'язані зі світом бізнесу, тобто та частина системи, в якій дозвільний клас керується мотивом отримання прибутку, а метою є демонстративне споживання.

Представники інституціоналізму усвідомлювали необхідність сфрормулювати парадигму нової інституціональної економіки і вимог до неї, оскільки очевидно, що вона не дана раз і назавжди. Але це має бути прийнято на основі консенсусу більшості дослідників і може періодично зазнавати фундаментальних трансформацій, що призводять до глибоких змін в науці, тобто наукових революцій і її істинність не повинна ставитись під сумнів.

Розглядаючи парадигми як фундаментальне наукове припущення, що у справі, яка вважається само собою зрозумілою і не суперечить дослідженням, потрібно виділити кілька основних питань, а саме: чи 
реальність має об'єктивний характер, чи частково суб'єктивна?; для того, щоб добре зрозуміти якийсь соціальний процес, потрібно бути його учасником, оскільки соціальна реальність піддається безперервній трансформації.

На думку К. Айреса кожна економічна система залишається під постійним тиском, з одного боку, різних інститутів (легенд, звичаїв, соціальної ієрархії), з іншого, під дією стимулів, породжених технологією. Звертаючись до інструментальної філософії, він проаналізував використання обмежених ресурсів для досягнення індивідуальних і групових цілей, сформулював постулат адаптації цих протилежних сил [33, с. 82]. Одним із напрямків цього процесу $\epsilon$ економічна система, що утворена двома, пов'язаними один з одним, але такими, що знаходяться в протиріччі, блоками: перший блок економіки - ціновий, що асоціюється 3 комплексом історично сфрормованих інститутів і бере за основу церемоніальну поведінку, значення якої залежить від влади, заснованої на силі грошей; другий - це блок економіки промислового виробництва, заснованої на технології, науці і поширенні знарядь праці.

Цінні ідеї для будівництва нової неоінституціональної парадигми економіки наштовхнули Карла Поланьї, який провів аналіз розпаду цивілізацій, золотого стандарту, саморегульованого ринку і ліберальної держави. На його думку, руйнація сучасних цивілізацій відбувається саме тому, що його економіка була заснована на особистих інтересах і діяла проти інтересів суспільства[33, с. 82]. Ці міркування підкріплюються аргументами економічної антропології.

І. Лакатош намагався примирити основні погляди К. Поппера і С. Куна, у пошуках певного синтезу їх поглядів, одночасно проповідуючи свої власні думки. Лакатош вважав, що при вивченні економіки потрібно виділити концепції наукових дослідницьких програм, під якими розуміється невелика частина більш або менш пов'язаних теорій. В їх структурі виділяється "тверде ядро", яке утворює сукупність фундаментальних і умовно незаперечних припущень, зміст яких піддається повільним змінам; а також "захисний пояс", який оточує "тверде ядро" і складається 3 
допоміжних гіпотез, модифікованих відповідно з потребами захисту основ наукової дослідницької програми та зміст якого повинен бути похідним [33, c. 84].

Ідея нової парадигми неоінституціональної економіки є рівнодіючою усіх існуючих поглядів сучасних представників різних шкіл інституціоналізму. Вона налаштована на цілісний підхід, що когнітивно нав'язує необхідність використання методу моделювання (зокрема і модель еталонного моделювання) і дозволяє зосередити увагу на співвідношеннях між частинами і цілим, шукати узгодженої єдності явищ і відстежувати процес соціальної еволюції. Вона базується вона на безлічі елементів, що утворюють ядро парадигми та "пояси безпеки", складових його оточення.

Ядро парадигми інституціональної економіки є чотири структурні елементи: "соціальні процедури" та "технології (ідеї світу бізнесу та промисловості (Т. Веблен), "філософія" (погляди прагматизму С. Ауреса, та інструменталізму Дж. Дьюї) і "середовище" (ґрунтується на поглядах економічної антропології К. Поланьї) [33, с. 85]. Кожен з цих елементів має свій власний "пояс безпеки", що утворений навколишнім середовищем і характеризує його основні ознаки. "Соціальні процедури" описані ключовими словами: інститути, переконання і цінності. У свою чергу "технології" описані ключовими словами: інструменти і кваліфікація. А "навколишнє середовище" конкретизують ознаки: фрлора, земля, фрауна, клімат[33, с.87].

"Філософрія" описується детермінантами правочинностей у підвищенні обізнаності (з посиланням на критерії соціальної легітимності - "соціальної правочинності" В. Ніла), демократії участі (по суті, представницької демократії."демократії участі") і самодостатності (з посиланням на самодостатність К. Поланьї).

Формула наведеної парадигми інституціональної економіки припускає, що спостерігач реальності, який має намір її досліджувати, не може бути нейтральним, і не буде об'єктивним, оскільки завжди є виразником певного світогляду. При цьому потрібно враховувати 
досягнення багатьох наук, щоб висловлювати оціночні судження. В той же час потрібно враховувати досягнення багатьох учень. Маючи це на увазі, Ф. Хейден і Дж. Ходжсон роблять спробу його нової інтерпретації. Дж. Ходжсон ввів в інституціональну економіку чотири питання: концепція обміну, що розуміється як передача прав власності; інститути ринку, що розглядається як набір соціальних інститутів, в яких перераховуються товари з особливою регулярністю; підприємства, які забезпечують зниження альтернативних витрат, діють в умовах невизначеності і практикують економічний облік; очікувань, що спричиняють створення інститутів, які сприяють формуванню в майбутньому змішаної системи соціально-економічного розвитку і в якій будуть співіснувати традиції, ринок і план [33, с. 191, 256].

Підставою для розгляду питання парадигми безпеки і парадигми економічної безпеки дають право на розгляд його крізь призму його структурних елементів, тобто його суб'єктів, об'єктів і навколишнього середовища.

Парадигма економічної безпеки, яка розглядається через призму суб'єкта, повинна бути співвіднесена не тільки до людини і суспільства, але і до спеціалізованих соціальних інститутів.

Стосовно окремої людини (індивідуума) парадигма економічної безпеку необхідно розглядати через призму елементарних потреб і, що призводить до забезпечення особистої безпеки. Серед них чільне місце посідають ті потреби, які мають універсальний характер (істина, добро, краса, справедливість). Безпеку особисті (індивідуальні) можна розгорнути в безпеку групи (родини), громади (локальної, релігійної, етнічної), суспільства (в рамках державної організації), нації (як специфічного суспільного організму), соціальних структур (політичних, економічних, воєнних, ідеологічних, екологічних), міжнародного співтовариства (регіональні, глобальні) .

У той час як стосовно суспільства (соціальних груп) безпека означає задоволення потреб існування, виживання, впевненості, стабільності, цілісності особистості, незалежності, збереження рівня і якості життя в 
рамках певних соціальних структур. Вона показує забезпечення і реалізацію фундаментальної потреби людини до асоціації, до утворення суспільних структур і процесу соціалізації індивіда.

Парадигма економічної безпеки розглядається як персональний код, як безпека особистості і суспільства: соціальної групи, соціальної спільності, народу, держави, міжнародної і цивілізацій.

У свою чергу, інституціональна парадигма економічної безпеки, що розглядається на рівні держави, повинна враховувати такі атрибути, як: географрічне положення, наявність природного і матеріального багатства, розвиток матеріальної і нематеріальної культури як джерела задоволення потреб і сприйняття ідеї економічної безпеки.

Виходячи з інституціонального теоретичного підходу до «безпеки як інституту сприйняття і поведінки», на основі аналізу об'єктивних і суб'єктивних аспектів ризику, можна виділити такі їі форми: безпеку, коли реальна загроза значна і її сприйняття відповідне; одержимість, коли незначна небезпека сприймається як велика; помилкову безпеку, коли суттєва загроза розглядається як незначна; реальну безпеку, коли зовнішня загроза незначна і сприймається адекватно. Підхід, який визначає «безпеку як процес» означає безперервну діяльність окремих осіб, підприємств, громад, держав і міжнародних організацій для створення потрібного стану безпеки.

Ще один підхід до категорії безпеки є їі сприйняття за критеріями негативний і позитивний. Під негативним розуміється здатність, а також можливість забезпечити виживання, в той час як позитивний підхід передбачає досягнення свободи розвитку. При такому підході до категорії безпеки бажаним є постійний перегляд двох зведених систем показників.

Поняття безпеки вказує, що вона застосовується до широкого спектру діяльності: держави, регіону або світу. Суть його полягає в недоторканності гарантій свободи, гарантованого виживання і розвитку. Вона визначається як категорія за об'єктивними показниками, а також суб'єктивними факторами, які важко піддаються кількісній оцінці. Хоча почуття загрози це примітивне відчуття, але досить важливим $є$ почуття того, що ви в безпеці. 
Наповнення інституціональними смислами ідеї національної безпеки вимагає, щоб вона визначала поведінку державних установ і силових структур. 3 цього погляду державну безпеку слід розглядати в цілому як організацію діяльності з підготовки до постійної безпеки, що включає такі елементи, як правове забезпечення, політику і стратегію, цивільні і військові організації охорони і оборони, інфраструктуру, економічну безпеку.

Конкретизуючи поняття економічної безпеки його слід відносити як до господарства (економіки), так і до господарювання (підприємництва, управління економікою). Обидва ці поняття сприймаються і визначаються по різному.

Отже, концепція економічної безпеки відносно національної економіки і категорій, що іï характеризують, з одного боку, виступає як відносно ізольована макросистема (або підсистема) суспільства, з іншого боку, як сукупність ресурсів і результат діяльності країн. Кожен з цих підходів дозволяє побачити інші сторони її сутності, структуру та функції, які можуть бути стимулом до діяльності настільки ж потужним як реальна загроза.

Для компанії найбільшим ризиком є ринковий ризик в тому сенсі, що, в результаті неправильних рішень, вона не може продавати свою продукцію на ринку, або продавати їх собі у збиток, що може негативно позначитися не тільки на фрінансовому стані але навіть загрожувати ії існуванню. Ризик - як внутрішній і зовнішній - може бути захищений чи застрахований. У той же час безпека зводиться до проектів, спрямованих на запобігання виникнення втрат. Тоді як страхування зводиться до зміни певної відповідальність на чиюсь іншу. Обидва ці рішення не $€$ взаємовиключними, але взаємно доповнюють одне одного і тому можуть бути використані одночасно.

Рішення на підприємстві в умовах невизначеності, тобто відхилення від рівноваги, яке не можна передбачити і розрахувати означає, що основою для них $є$ інформація при ситуацію, в якій ми були обізнані про можливі втрати. Невизначеність, як ризик, може бути як внутрішньою i зовнішньою. Невизначеність виникає в результаті зовнішніх обставин і не 
може бути передбаченою. Це може бути через неточні розрахунки витрат проведення прийняття рішень через відсутність відповідної інформації.

Зовнішня невизначеність - аналогічно і зовнішні ризики - згідно 3 тими ж умовами, $\epsilon$ таким які більш важко визначити, ніж внутрішні невизначеності. Обсяг можливостей ризику і невизначеності в найбільшій мірі стосується інвестицій та інновацій. Це виражається в існуванні небезпеки, що у використаному устаткуванні, технологія буде швидко старіти, тоді як снує більш сучасна та ефективна, яка здатна виробляти більш якісний продукт. Це створює ситуацію, за якої більш технічно ефективним пристрій не використовуються з економічної точки зору, а морально застаріла техніка амортизується.

Економічна безпека сприймається в різних вимірах, як глобальна регіональна, національна (державна) на рівні компанії та побутова.

Зосередивши увагу тільки на питанні економічної безпеки держави необхідно відзначити, що такий аспект вимагає першочергово визначення концепції національної безпеки. Така концепція дуже гнучка і істотно неоднозначна і розуміється досить широко. 3 одного боку - як умова, яка визначається комбінацією чинників та обставин що піддаються раціональному судженню, з іншого боку, як суб'єктивне відчуття уряду і населення, що країна є безпечною. Причина цього криється в національних відносинах у сфрері безпеки з волею, щоб вижити, і таким чином підтримувати свої власні екзистенційні інтереси.

\section{2. Розвиток форм економічної безпеки}

Інформаційно-аналітичне забезпечення системи управління економічною безпекою підприємства визначає її якість.

Найбільш значуща властивість інформації - це здатність викликати інституціональні зміни в цілому та окремих її лементах. Неодмінною умовою виживання в умовах ринку та збереження конкурентоспроможності $€$ адаптація до мінливих потреб ринку та забезпечення економічної безпеки підприємства. Практично цінність інформації прямо пропорційна тій ролі, 
яку вона відіграє в прийнятті управлінських рішень. Цінність інформації визначається тим, як суб'єкт зможе розпоряджатися нею. Інформація, покликана забезпечити прийняття рішень, вносить істотний вклад у прийняття управлінського рішення. Вона стає фрактором виробництва та подібно праці, матеріалам і капіталу дозволяє створювати додану вартість, тому інформація $€$ критерієм забезпечення економічної безпеки підприємства [20].

Основними властивостями інформації $€$ : повнота, вірогідність, цінність, актуальність і ясність.

Аналітичну обробку інформації дуже важливо здійснювати на основі системного підходу, що дозволяє розкрити комплексність об'єкта, багатогранність зв'язків і звести їх у єдину цілісну систему. При системному підході визначаються основні цілі системи, досягненню яких повинні сприяти вихідні дані та одержана результативна інформація. За цілями конструюється система. Під системою в цьому випадку розуміється набір елементів і інформаційні зв'язки, що виникають між ними і які забезпечують оптимальне безпечне управління економікою підприємств.

Управління економічною безпекою підприємства повинне включати такі підсистеми: інформації, систем показників, індикаторів і методів оцінки та аналізу економічної безпеки підприємства.

Система аналітичної інформації для прийняття управлінських рішень відрізняється складністю. Причому спостерігається тенденція ускладнення взаємозв'язків в інформаційному потоці. Одночасно відбувається систематичне зростання обсягів інфрормації, її надмірності при інформаційній недостатності для прийняття оптимальних управлінських рішень. Інформація щодо забезпечення економічної безпеки підприємства досить неоднорідна. Усе це ускладнює їі використання в управлінні економічною безпекою.

На більшості підприємств інформація, яка використовується менеджерами для забезпечення економічної безпеки, забезпечують внутрішні джерела. Створюється спеціалізована аналітична група, або служба економічної безпеки підприємства, до складу функціональних 
обов'язків якої повністю або частково включається інфрормаційне забезпечення [20].

Створення раціонального потоку інформації про економічну безпеку підприємства повинне опиратися на такі принципи:

- уніфікованості, що припускає те, що аналітики повинні прагнути до того, щоб проектні рішення, які ними пропонуються, підходили до якомога ширшого кола завдань, які вирішуються;

- системності, що припускає встановлення порядку функціонування всієї системи аналітичної інформації в цілому і її динамічних тенденцій;

- принцип вирішення нових завдань, що дозволяє виявляти та вирішувати нові завдання, які ставляться перед підприємством у зв'язку 3 ускладненням зовнішнього середовища;

- принцип першого керівника, заснований на безпосередньому керівництві аналітичною роботою на підприємстві першим керівником у зв'язку з тим припущенням, що він буде постійно націлювати аналітичний відділ на рішення нових більш складних завдань і намагатися вивести підприємство на лідируючі положення в конкурентному середовищі;

- принцип розвитку - розроблений комплекс вирішення аналітичних завдань повинен створюватися з урахуванням можливості поповнення та постійної актуалізації без порушення його функціонування;

- принцип сумісності - при створенні системи повинні бути реалізовані інформаційні інтерфейси, завдяки яким вона може взаємодіяти з іншими системами відповідно до встановлених правил;

- принцип стандартизації, що припускає те, що при створенні аналітичних комплексів повинні бути раціонально застосовані типові уніфіковані та стандартизовані елементи, проектні рішення, пакети прикладних програм, зокрема такі, які дозволяють займатися побудовою економіко-математичних моделей;

- принцип ефективності полягає у досягненні раціонального співвідношення між витратами та цільовими ефектами, включаючи кінцеві результати автоматизації;

- принцип єдиної інформаційної бази, що припускає те, що вихідна 
інформація один раз вводилась в систему та могла бути використана багаторазово.

Інформація повинна бути повною та своєчасною, достовірною, корисною та зручною для сприйняття та подальшого використання. Необхідність збору, накопичення та зберігання економічної інформації диктується багатьма обставинами. До них належать: багаторазовість і тривалість їі застосування, розрив у часі між збором і використанням інформації при проведенні аналізу та управлінні економічною безпекою на підприємстві [20].

Хаотичність потоків інформації, недосконалість їх каналів, методів і техніки збору, зберігання та обробки приводять до істотного запізнювання інформації і до втрати її якості та виникнення загроз для підприємства. Основа сучасного одержання інформації - це інтеграція ії збору та обробки. Результати проведення аналітичних досліджень прямо залежать від якості інформації, яка використовується, тому перед їх проведенням слід ретельно перевірити вхідну інформацію.

Систематизацію та підготовку джерел інформації для аналізу можна розділити на два етапи: перевірка їх змісту; обробка та вивчення матеріалів.

Процес підготовки матеріалу до аналізу економічної безпеки підприємства включає також приведення показників у порівнянний вид і спрощення цифрового матеріалу. Однорідність і порівнянність даних обов'язкова умова одержання правильних результатів при проведенні економічного аналізу. Найпоширенішими прийманнями приведення показників у порівнянний вид $€$ :

- нейтралізація ціннісного фрактора шляхом відображення різних видів об'ємних показників у єдиних цінах;

- нейтралізація кількісного фрактора при аналізі ефективності використання якого-небудь виду ресурсу за допомогою розрахунку ряду умовних показників, де незмінним залишається об'ємний показник і послідовно змінюється величина ресурсу, що витрачається;

- нейтралізація впливу на рівень кількісних і якісних показників 
методик їх розрахунку. Сукупність однорідних планових, звітних і облікових показників повинна мати єдину методику визначення;

- вирахування середніх величин при вивченні ряду однорідних показників;

- заміна абсолютних величин відносними, коли це найбільш доцільно, для більшої наочності, доступності та сприйнятливості.

У процесі аналізу виявляються переваги та недоліки інформації, повнота її використання для аналізу та управління економічною безпекою.

Інформацію про економічну безпеку підприємства використовують як внутрішні, так і зовнішні користувачі.

До якості економічної інфрормації пред'являються певні вимоги, насамперед, вимога про те, щоб вона задовольняла користувачів інформації, інакше кажучи, була корисною.

Звичайне забезпечення управлінського персоналу відповідною інформацією залежить від розподілу функцій між виконавцями. Із цією метою для кожного керуючого розробляються посадові інструкції, у яких перелічуються функції, які він виконує. На підставі посадових інструкцій визначається той обсяг інформації, який необхідний для забезпечення економічної безпеки підприємства.

Економічні показники для проведення оцінки і аналізу економічної безпеки підприємства повинні бути представлені у вигляді системи. Система показників - це їх упорядкована сукупність, у якій кожний показник дає кількісну або якісну характеристику певної сторони господарської діяльності, має властивості зведення та подільності, пов'язаний з іншими показниками, але не дублює їх [21].

Інформаційна база економічної безпеки, яка існує на підприємстві, становить систему показників, вірогідність, періодичність поновлення, повнота та автоматизація якої забезпечує якість прийнятих управлінських рішень. Система показників для проведення фундаментальних аналітичних досліджень економічної безпеки повинна враховувати такі вимоги до їх формування [19]:

- у систему повинні входити декілька окремих (частинних) показників 
і один узагальнюючий, залежний від частинних;

- загальнотеоретична інтерпретація

взаємозв'язок і

цілеспрямованість як окремих показників, їх груп, так і всієї системи в цілому;

- для системи повинна бути характерною інтегрованість, що дозволяє застосовувати її при програмно цільовому управлінні економічною безпекою та будувати «дерево» цілей економічного та соціального розвитку підприємства;

- можливість регуляції значень величини показників залежить від досягнутого рівня економічної безпеки та наявності потенціалу їі досягнення в майбутньому;

- наявність достатньої кількості показників для оцінки окремих функціональних складових економічної безпеки підприємства;

- усі показники в системі повинні бути реальними та динамічними;

- можливість одержання прогнозу про спрямованість динаміки показників;

- показники повинні бути значимими (найбільш важливими для дослідження економічної безпеки);

- у системі показників, які використовуються при проведенні оцінки та аналізу економічної безпеки підприємства, необхідно враховувати галузеві особливості підприємства, його конкурентну стратегію та стадію життєвого циклу, на якому воно знаходиться.

Основними причинами депресивного розвитку державної науковопромислової політики є технологічна відсталість суб'єктів господарювання, низький рівень науково-дослідних конструкторських розробок, перевищення нормативів фрізичного зносу основних засобів. Такі глобальні проблеми призводять до зниження конкурентоспроможності продукції підприємства, та, як наслідок, до зниження рівня їх економічної безпеки. Менеджмент вітчизняних промислових підприємств в основному вважає, що держава повинна їм забезпечити належний рівень економічної безпеки, але без значних зусиль самих підприємств у цьому напрямі сучасний рівень може знизитися ще більше, в результаті чого лідируючі позиції на 
світових ринках займуть товаровиробники інших країн. Одним із ключових компонентів економічної безпеки підприємства $€$ її техніко-технологічна складова. Функціонування промислового підприємства значною мірою визначається надійністю підсистеми техніко-технологічної безпеки, тому дослідження згаданих проблем є важливим та актуальним.

Головною метою реформування та розвитку залізничного транспорту в більшості країн світу $є$ підвищення економічної безпеки національної економіки за допомогою утримання чи підвищення конкурентних переваг залізниці порівняно з іншими елементами транспортної інфраструктури та сприяння вищим темпам господарського зростання.

Вивчення наукових праць вітчизняних і зарубіжних фахівців у галузі реформування залізниці в провідних країнах Європи, Латинської Америки, США, Японії, Китаю, в яких триває розробка підходів до оцінювання ефективності інституціональних перетворень залізничної галузі, дає можливість пошуку механізмів державного регулювання розвитку підприємств залізничного транспорту [9].

Для ефективного реформування залізниці Україні потрібно прийняти чималий пакет законів: «Про транспортну безпеку», «Про основи ціноутворення на залізниці»; внести доповнення до Податкового кодексу та розробити інші нормативні акти, що потребує чималих зусиль і часу. У зв'язку із цим у ході структурних перетворень на залізницях України доцільно меншою мірою використовувати досвід британської «приватної ринкової» моделі перетворень і більшою - концепцію здійснення структурних реформ залізничного транспорту Німеччини, що забезпечує збереження централізованих важелів управління 3 одночасним застосуванням в окремих галузях децентралізації та конкуренції. Треба враховувати, що залізниці - одна 3 найбільш капіталомістких інфраструктурних мереж, які найважче піддаються реформуванню.

Безпеку на рівні підприємства відображає рівень захищеності господарської діяльності від негативних впливів зовнішнього середовища, а також здатність швидко усувати загрози життєдіяльності підприємства або пристосуватися до існуючих умов, які не позначаються негативно на його 
діяльності [27, с. 133].

В економіці України відбуваються суттєві зміни, зумовлені глобалізацією підприємницької діяльності, швидкими темпами розвитку інфрормаційних технологій.

Сучасні системи автоматизації економічної діяльності підприємств включають великий набір типових рішень, що забезпечують основні ділянки управління та адаптованих до сучасних умов господарювання, проте на кожному конкретному підприємстві $€$ свої неповторні особливості, які неможливо заздалегідь передбачити. Часто виникає необхідність особливим чином вводити, збирати та аналізувати документи чи окремі дані, виконувати нестандартні дії чи готувати індивідуальні звітні форми $[17$, с. 5$]$.

Сучасна практика діяльності підприємств стикається 3 різними викликами внутрішнього та зовнішнього середовища, до вирішення яких уповноважені представники не готові. Така ситуація спостерігається внаслідок різноманітного впливу чинників, несвоєчасної реакції на зміни в ринкових відносинах, а також низької кваліфікації керівної ланки. Одним $з$ інструментів, який може знизити негативний вплив названих елементів, $€$ сучасні інформаційні технології. Їх використання на підприємстві дає змогу згладити некомпетентність персоналу у вирішенні складних завдань у бізнес-діяльності, підвищити оперативність отримання готових результатів, поліпшити якість одержуваної інформації. Це, у свою чергу, позитивно впливає на економічні результати підприємницької ініціативи та їі економічну безпеку.

3 розвитком інформаційних технологій удосконалювалися також методи, засоби управління інфрормаційними технологіями та інформаційними ресурсами. Зараз розроблені та застосовуються різні засоби управління інфрормацією в системі забезпечення економічної безпеки підприємств, серед яких сучасна техніка та обладнання, програмне та документальне забезпечення, технології зі штучним інтелектом, автоматизовані ресурси з управління інформаційними потоками у відкритих і закритих мережах. Глобальна мережа Інтернет також є потужним засобом 
управління інформацією, особливості здійснення якого можуть як підвищити економічну безпеку підприємств, так і знизити їі. Розвиваються методи управління інформаційними технологіями в системі забезпечення економічної безпеки підприємств. Про це свідчать фракти їх адаптації під процес управління інфрормацією в системі забезпечення економічної безпеки в умовах застосування сучасних інформаційних технологій.

Діяльність підприємств супроводжується використанням безлічі каналів різної інформації, управляти якою потрібно таким чином, щоб не створювати загроз економічній безпеці. Дуже важливо враховувати можливості сучасних інформаційних технологій, особливо мережі Інтернет. У цьому інформаційному ресурсі існують різні можливості для просування бізнесу та вирішення поточних проблем або завдань. Зокрема, до таких сервісів належать соціальні мережі, хмарні технології, засоби державних служб з обробки різної звітності підприємців, фінансових установ та інших спеціалізованих суб'єктів. Тільки використання хмарних технологій як сучасного інформаційного ресурсу на практиці дає змогу оперативно обробити потрібну інформацію підприємства, отримати розрахункові результати за заданими параметрами, розрахувати можливі вигоди від угоди або просто ознайомити з особливостями того чи іншого заходу.

Загалом для забезпечення власної безпеки підприємство повинно використовувати різні інформаційні технології за допомогою таких засобів управління інформацією [1]:

- технічних (охоронно-пожежні системи, відеоапаратура тощо);

- організаційних (створення спеціалізованих підрозділів або структур, що забезпечують безпеку підприємства, а також систем управління);

- інформаційних (комп'ютери, захисні мережі та інформаційна продукція, у тому числі необхідна для прийняття рішень інформація);

- фінансових, без яких і функціонування системи безпеки буде неможливим;

- правових (у тому числі розробка локальних правових актів з питань функціонування системи управління та забезпечення економічної безпеки); 
- кадрових (насамперед, формувати достатню кількість персоналу, що займається питаннями безпеки, його профресіоналізм);

- інтелектуальних (залучення висококласних фрахівців і науковців дає змогу розробляти нові системи безпеки).

Застосування підприємством вищенаведених засобів для забезпечення безпеки переводить їх до категорії методів, тобто способів дії. Таким чином, підприємство може застосовувати технічні, організаційні, інформаційні, фрінансові, правові, кадрові та інтелектуальні методи управління інформацією. Важливою групою методів також є економічні, що включають у себе не тільки фінанси та кадри, а і маркетингові методи, менеджмент, економіко-математичне моделювання, статистичний аналіз, а також конструктивно-розрахунковий метод. Відповідно, у контексті необхідності забезпечення економічної безпеки підприємство, виходячи з власних потреб, специфіки та можливостей (ресурсів), використовує для цього всі наявні корпоративні ресурси, що зумовлює характер засобів і методів її забезпечення.

У практиці підприємницької діяльності описані вище засоби управління інформацією в системі забезпечення економічної безпеки підприємства потрібно використовувати з метою:

- пошуку та отримання інформації, необхідної для забезпечення стабільної діяльності та динамічного розвитку підприємства і його систем безпеки в умовах мінливих небезпек, загроз та ризиків ринкової економіки;

- виключення використання недостовірної інформації в системі управління підприємством, у його виробничій діяльності та в системі безпеки;

- запобігання несанкціонованому доступу до інформаційних ресурсів підприємства;

- запобігання розкраданню та втраті інформації підприємством;

- запобігання внесенню недостовірних даних, підміні та підробці інформації, що застосовують у системі управління, виробничій діяльності, системі безпеки підприємства в цілому;

- запобігання несанкціонованим діям щодо знищення, модифікації, 
псування, копіювання та блокування інформації;

- захисту інтелектуальної власності підприємства.

Для вирішення завдань управління інформацією в системі забезпечення економічної безпеки підприємства в умовах використання сучасних інформаційних технологій доцільно надати модель комплексного інформаційного забезпечення системи економічної безпеки підприємства.

Механізм управління інформацією в системі забезпечення економічної безпеки підприємства включає в себе такі елементи:

- забезпечення підприємства достовірною інформацією, необхідною для ефрективного управління;

- безпека інформаційного середовища підприємства;

- захист інфрормаційних ресурсів та інтелектуальної власності підприємства від несанкціонованого доступу;

- підсистема інформаційного забезпечення;

- пошук інформації (всіма законними методами);

- систематизації та аналіз отриманої інфрормації;

- підготовка аналітичних документів;

- комплексна система інформаційної безпеки;

- уточнення та пошук додаткової необхідної інформації;

- уточнення підготовлених і розробка додаткових аналітичних документів;

- підсистема захисту інтелектуальної власності;

- організаційні заходи щодо захисту інформаційних ресурсів;

- інженерно-технічні засоби попередження несанкціонованого доступу до інформаційних ресурсів підприємства;

- доведення інформації до керівників підприємства та керівників його підрозділів;

- правовий захист інформації та інтелектуальної власності.

Запропонований механізм управління інформацією в системі забезпечення економічної безпеки підприємства дає змогу використовувати сучасні інформаційні технології. Мало того, його 
результативність та ефективність значно підвищиться, якщо кожен елемент буде опрацьовуватися в тому чи іншому програмному забезпеченні або ж буде піддаватися аналізу в сучасній моделі обробки економічних даних. Механізм управління інформацією в системі забезпечення інфрормаційної безпеки підприємства складається з двох підсистем.

Перша - підсистема інформаційного забезпечення. Вона призначена для своєчасного отримання в необхідних обсягах достовірної інформації про процеси, що відбуваються на ринку та можуть вплинути або впливають на діяльність і розвиток підприємства, а також на стан його безпеки. Необхідна також інформація про конкурентну ситуацію, нові ідеї та наукові розробки, появу перспективних зразків техніки та технологій, інноваційних процесів тощо. Без цієї інформації керівництво підприємства не може розробити ефективну стратегію, що відповідає реаліям ринку, а також здійснювати результативне тактичне та оперативне управління, забезпечувати заходи безпеки. У запропонованій моделі простежується таке: щоб отримати необхідну інформацію для прийняття рішень у сфері управління підприємством, необхідно здійснити всіма законними методами пошук потрібної інформації, потім провести систематизацію та аналіз отриманих відомостей, підготувати аналітичні документи та довести їх до керівництва підприємства та інших посадових осіб. При цьому постійно оновлювати та поглиблювати інформацію 3 урахуванням поточних і перспективних напрямів діяльності підприємства і його систем безпеки. Особливої уваги потребує налагодження тісного взаємозв'язку між елементами підсистеми інформаційного забезпечення економічної безпеки підприємства.

Друга підсистема призначена для захисту інформації та інтелектуальної власності підприємства. Вона включає організаційні заходи щодо захисту інформаційних ресурсів, інженерно-технічні засоби запобігання несанкціонованому доступу до інформаційних ресурсів і правовий захист інформації та інтелектуальної власності підприємства.

Обидві підсистеми взаємопов'язані між собою та працюють у комплексі. Якщо одна з підсистем працювати не буде, то ефективність 
управління інформацією в системі забезпечення економічної безпеки підприємства істотно знизиться.

Досить часто в підприємницькій діяльності виникає необхідність прийняття рішення щодо вибору найкращих і ефективних інформаційних технологій (IT). Вирішення цього завдання є складною та багатогранною проблемою, оскільки керівник, приймаючи рішення, перебуває в дуже складному становищі, що супроводжується невизначеністю та ризиком. У зв'язку із цим актуальним стає вибір методів і прийомів, що сприяють успішній розробці та прийняттю економічно обґрунтованих і досить аргументованих управлінських рішень щодо впровадження інформаційних технологій.

Для впровадження інформаційних технологій на підприємстві потрібно детально аналізувати не тільки сам інформаційний продукт, а і оцінити ефрективність доцільності його впровадження, проаналізувати різні фактори впливу, тільки потім приймати відповідне рішення. Ефективна інформатизація значно підвищує керованість процесами соціальноекономічного розвитку підприємства, приводить до поліпшення якості та рівня прийнятих управлінських рішень, оперативності інформаційних процесів і послуг, які забезпечують поліпшення економічних, науковотехнічних, культурних та інших показників [1].

Для якісного та раціонального управління інфрормацією в системі забезпечення економічної безпеки підприємствам потрібно використовувати широкий набір засобів, важливу роль серед яких сучасні інформаційні технології. Для підвищення ефективності та віддачі засобів і методів управління інформацією потрібно важливі управлінські рішення аналізувати на підставі їх сукупності, у результаті чого реалізовувати найбільш вигідні результати.

Також з метою підвищення економічної безпеки підприємств можна використовувати різні інформаційні продукти, що дають змогу врахувати техніко-технологічні, ресурсні, комунікаційні та інші можливі параметри підприємницького середовища. За допомогою проведення відповідних розрахунків потрібно інтерпретувати отримані результати 3 метою 
подальшого прийняття рішень про поліпшення наявних параметрів, які впливають на систему забезпечення економічної безпеки підприємств.

Інформаційне забезпечення фінансової діяльності підприємства являє собою процес безперервного цілеспрямованого підбору відповідних інформативних показників, необхідних для здійснення ефективних управлінських рішень за всіма аспектами фрінансової діяльності підприємства.

Інформаційне забезпечення для керівної підсистеми фінансового механізму має велике значення, оскільки при прийнятті управлінських рішень у галузі фрінансів від якості використовуваної інформації значною мірою залежать обсяг витрат фрінансових ресурсів, рівень прибутку, ринкова вартість, правильність вибору інвестиційних проектів і фінансових інструментів інвестування та інші показники. Чим більший розмір капіталу використовує підприємство, тим важливіша якість інформації, необхідної для прийняття фінансових рішень, спрямованих на підвищення ефективності діяльності підприємства.

Для досягнення цих цілей важливо допомагати підприємствам автоматизувати виробництво, ефективніше використовувати переваги нових інформаційних технологій і систем; упроваджувати телекомунікаційні мережі, які забезпечуватимуть швидкий, надійний, безпечний і економічний доступ до інформації всіх користувачів; розвивати ІТ-кадровий потенціал; сприяти наданню інформаційних послуг у режимі реального часу.

\section{3. Формування нових моделей економічної безпеки підприємств}

На сьогодні дестабілізуючі фрактори (політичні, військові, психологічні) для розвитку економіки України створили загрозу економічній безпеці та збереження цілісності ії економічного простору. Викликані вони, по-перше, важкими економічними потрясіннями, спровокованими глобальною кризою, на тлі якого загострилася істотна невизначеність станів в суспільноекономічних системах. Це ускладнює процес моделювання основних 
економічних процесів в будь-якій країні, а значить і їх дослідження та прогнозування. Особливістю глобалізаційних процесів є їх масштабність: трансформаційне вплив глобалізації стосується не тільки окремих країн, регіонів, а й діяльності конкретних підприємств. Глобалізація не тільки генерує кількісні і якісні трансформації економічних систем держави, а й сама $€$ їх результатом. По-друге, існує висока конкуренція продукції на європейському і світовому ринку. Україна, котра переживає затяжну соціально-економічну кризу, намагається вирішувати проблеми стабілізації, i, разом з тим, окреслити основні напрями розвитку економіки. Адже посилення національної конкурентоспроможності України безпосередньо пов'язане з інтенсивним розвитком підприємств. По-третє, підприємства України зіткнулися з природним прагненням промислово розвинених країн, великих іноземних корпорацій використовувати ситуацію в Україні в своїх економічних і політичних інтересах. Тому для економіки України надзвичайно актуальними стали питання економічної інтеграції. Все це загострило проблему економічної безпеки підприємств України.

За останні кілька десятиліть поєднання розвитку технології і досягнень в області економіки поставило під сумнів деякі фундаментальні передумови, на яких гуртувалася традиційна (неокласична) структура аналізу. Відповідно до неокласичних підходів раціональність економічних агентів $€$ повною і незалежною. Як умову поведінки економічних агентів слід виділити наступне: вибір варіанта використання ресурсів має свідомий характер, тобто допускає знання мети своїх дій і можливостей використання ресурсів. Знання може бути достовірним, а може включати лише деяку достовірність і тому без наявності інформації про цілі та ресурсні обмеження вибір варіанта дії (використання ресурсів) неможливий.

Тому актуальною в діяльності підприємств стала проблема розробки нового підходу до забезпечення економічної безпеки підприємства. Для визначення основних загроз економічній безпеці підприємства необхідна розробка аналітичного інструментарію, критеріїв оцінки, визначення фракторів, які впливають на ефективну діяльність підприємств, а саме їх 
економічну безпеку.

Таким чином стають актуальними визначення завдань комплексного визначення набору складових економічної безпеки підприємства, виявлення і класифікація фракторів ризику, що впливають на економічну безпеку підприємств в сучасних економічних умовах, що підтверджує актуальність нового проектного підходу до фрормування економічної безпеки підприємства, визначає необхідність пошуку способу інтеграції теоретичних розробок економічної науки 3 практичними результатами дослідження стану економічної безпеки підприємств залізничного транспорту України.

Здатність до абстрагування властива людському розуму. Вона дозволяє йому надати щодо точної форми своїм мисленням, сорормулювати принципи та інструментарій проектування та моделювання i, таким чином, виробити методологію - систему знань, яка характеризується логічно взаємоузгодженими твердженнями і гармонійним взаємозв'язком окремих економічних дисциплін. У сфрері економічної діяльності несприятливі умови і чинники впливають на зниження безпеки і стають причинами втрат, які можуть понести підприємства при реалізації виробничих проектів. Одним 3 напрямків вирішення цього завдання $\epsilon$ вдосконалення управління ефективністю великих виробничих проектів підприємств: організаційно-економічних, виробничо-технологічних та інноваційно-технічних.

Зазначені тенденції відповідають сучасним перетворенням на залізничному транспорті в умовах загальної інтеграції господарських зв'язків, глобалізації світової економічної системи і вимагають наукового аналізу проблем управління корпораціями і розробки методів оцінки ефективності корпоративних трансформацій на залізничному транспорті України. Процес теоретико-методичних розробок в порівнянні з процесом запланованих реформ в галузі актуальний, тому що підвищує наукову обґрунтованість прийняття організаційно-економічних та управлінських рішень.

На відміну від неокласичної доктрини, яка розглядає економічну 
систему як механічну спільність ізольованих один від одного індивідів (атомізм) та виводить властивості системи з властивостей складових її елементів (індивідів), інституціоналістів підкреслюють важливість зв'язків між елементами для формування властивостей як самих елементів, так і системи в цілому. Цей підхід, який відбивається поняттям «холізм» і проголошує переважання соціальних відносин над психофізичними якостями індивідів, визначає сутнісні властивості економічної системи. Органічний підхід поділяли і деякі представники класичної школи, але ні в кого з них ця ідея не займала центрального місця. Сучасна наука все більшою мірою зосереджується на вивченні взаємодії між елементами системи.

Поряд з багатьма проаналізованими теоретичними і методичними економіко-управлінськими аспектами управління ефективністю великих виробничих проектів, які відносяться до чинників економічної безпеки підприємства, традиційні дослідження з економічної безпеки сфокусовані на режимних, криміногенних, технічних, інформаційних, виробничих і екологічних аспектах. 3 огляду на необхідність фрормування економічної безпеки підприємства, актуальною стає проектна парадигма, яка характеризується розробкою, фрормування і створенням ще відсутньої в практиці системи безпеки.

Виходячи з цього, виникає необхідність забезпечення наукового опису і конструктивної розробки принципово нових проектів економічної безпеки підприємства та її фрагментів, які відрізняються від попередніх.

Підприємства «Укрзалізниці» - залізниці України, розвиваються в умовах глобалізаційних процесів світової господарської системи. Це характеризується відкритістю всіх видів ринків, сильними інтеграційними процесами, посиленням впливу світового фрінансового ринку, взаємозалежністю національних економік і високим динамізмом економічних, соціально-політичних, екологічних, психологічних, культурних процесів. Але разом з цим, залізниця України має серйозні проблеми, пов'язані з її неефективністю і збитковістю. Внаслідок цього уряд України намірився реорганізувати «Укрзалізницю», перетворивши її в акціонерне 
товариство. Успіх реформи буде прямо залежати від її безпосередніх виконавців, зокрема керівництва «Укрзалізниці».

Світовий досвід реформування залізниць налічує кілька десятків років. Реформи на залізницях, що проводяться з ініціативи ЄС, теж просуваються недостатньо швидко. Але залізні дороги України багато років залишалися в нереформованому вигляді. Початок реформ було покладено тільки в 2012 році. Досягнення влади в плані реформування монополіста залізничних перевезень за останні кілька років можна звести до чергового підвищення тарифів і проведення «конкурсу» на посаду гендиректора. Єдиною реальною і ефективною реформою «Укрзалізниці» стало впровадження системи «Електронний квиток».

Останні роки активно обговорюється варіант приватизації «Укрзалізниці». Але практика довела, що приватизація великих і середніх підприємств в умовах відсутності державного контролю, кваліфрікованих менеджерів, недосконалості системи менеджменту, маркетингу виявилася помилковою. Керівництво таких компаній направляло прибуток не на розвиток, а на виплату заробітної плати і т.п., або на своє особисте збагачення. Тому на підприємствах не відбувалося потрібних реструктуризаційних змін, що спричинило прискорення занепаду через зростання високої енерго- і матеріалоємності продукції, скорочення обсягів капітальних вкладень, відсутність контролю якості, нехтування потребами споживачів, відсутність довгострокових господарських зв'язків.

Для обґрунтування авторського трактування моделі проектування економічної безпеки залізничного підприємства була розроблена модель проектування економічної безпеки підприємства.

Для початку слід визначитися з алгоритмом процесу проектування. Цей алгоритм складається з декількох позицій.

По-перше, визначаються структурні і процесуальні характеристики проектної діяльності, які сприяють вирішенню проблем економічної безпеки підприємств. По-друге, вибирається об'єкт: система економічної безпеки в цілому або її структурні компоненти. По-третє, організовується продуктивна діяльність, результатом якої $€$ проект, що впроваджується в практичну 
діяльність та в процесі реалізації.

Конкретизуємо модель, яка зображена на рис. 4.1.

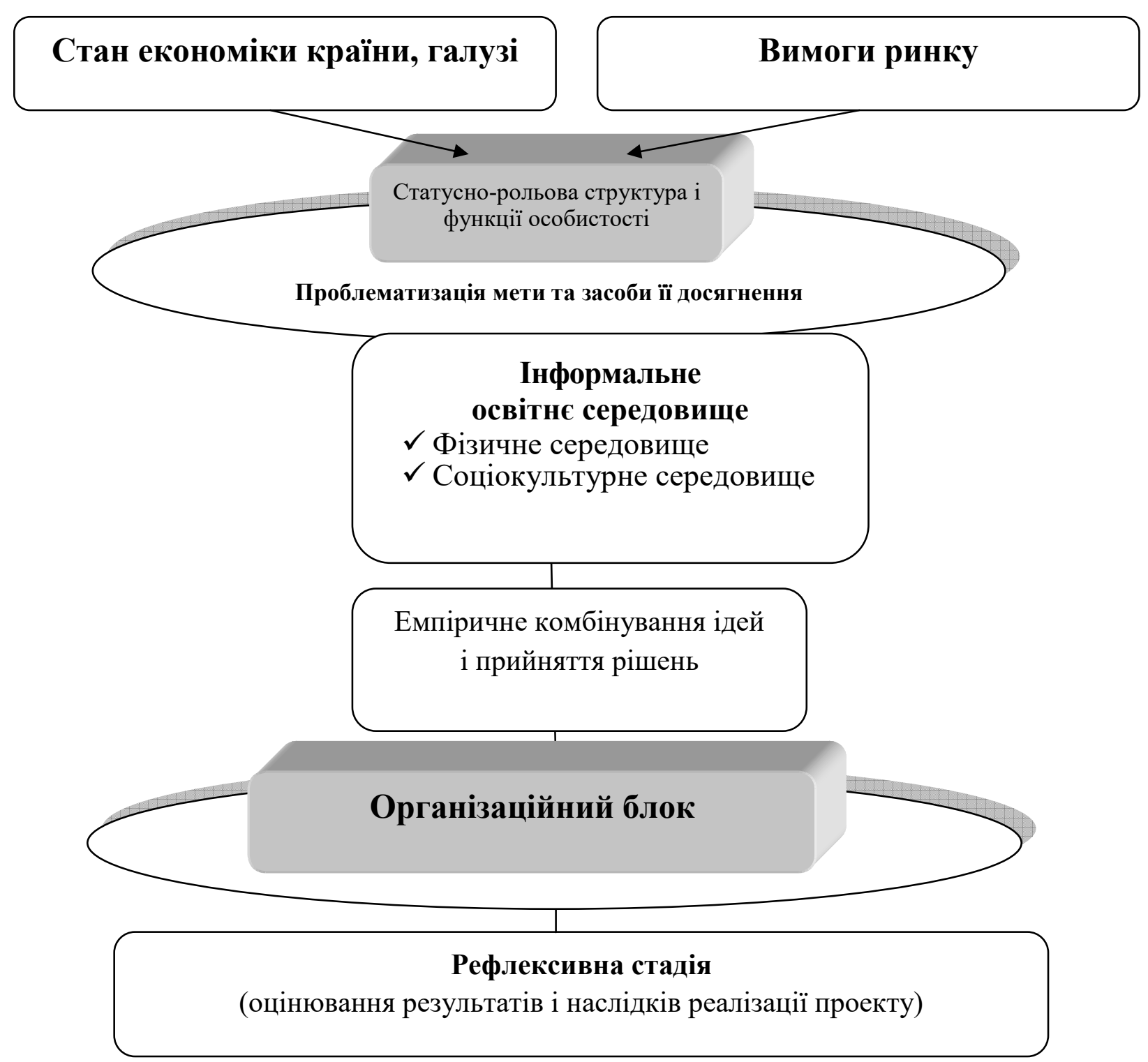

Рис. 4.1. Модель проектування економічної безпеки підприємства

Цілепокладання проектування моделі економічної безпеки підприємства пов'язане з незадоволенням наявної ситуацією - виявлення негативного впливу на соціально-економічну стійкість підприємства. Тому виникає потреба в ідентифікації найбільш імовірних зовнішніх і внутрішніх загроз економічній безпеці підприємства у вигляді аналізу стану економіки галузі. 
Ці процеси збуджують розумову діяльність учасників проектування, які починають теоретичне моделюванням проекту з визначення головних цілей діяльності підприємства, його місця та статусу. Але визначення мети - це тільки уявлення про результат. Щоб його реально отримати, мету треба проблематизувати в контексті засобів її реалізації - це методи та процедури наукового пізнання. Мети досягають шляхом вирішення окремих завдань, пов'язаних з прогнозуванням, розробкою, комбінуванням ідей та прийняттям рішень, моделюванням, а також технологічним забезпеченням.

Далі відбувається емпіричне комбінування ідей і прийняття рішень щодо практичного їх втілення.

Створення теоретичного уявлення про економічну безпеку підприємства, перспективи функціонування підприємства, виявлення загроз і суперечностей сприяють формуванню її теоретичної моделі у вигляді бажаного результату в діяльності підприємства. Результатом такого проектування стає певний проект, функціональна специфіка якого залежить від певних умов: стану середовища, в якому працює підприємство, особливостей суб'єктів господарювання, функціональних зв'язків між структурами підприємства, можливостей реалізації проекту, очікуваних результатів. Актуалізація і проблематизація цих вимог формує важливу місію в теоретичному проектуванні моделі економічної безпеки підприємства, а саме просування ідей та ратифікація нового знання. На цьому етапі проектування відбувається вихід за межі традиційних підходів, набуття нової норми (досвіду), формування гіпотези проекту безпеки підприємства.

На завершальній стадії проектування моделі економічної безпеки підприємства здійснюється рефрлексивне оцінювання функціонування економічної безпеки підприємства, що передбачає трансформацію моделі економічної діяльності підприємства. Цей процес передбачає осмислення завдань проектування, адже будь-яке рішення не можна вважати остаточним. Після завершення проектного циклу в процесі функціонування підприємства відбуваються зміни, які вимагають нових проектних досліджень і розробок. 
Таким чином, процес проектування моделі безпеки підприємства перетворюється на перманентний. Це передбачає необхідність постійного дослідження рефлексивних зв'язків між процесом проектування і станом економічної безпеки на підприємстві, а їх результати мають бути враховані на наступних стадіях проектування. Підсумовування результатів проектування передбачає осмислення наслідків заходів, спрямованих на сприяння економічній стабільності.

Проведення економічних реформ в Україні, реалізація конкретних цілей і завдань рефрормування об'єктивно зумовлює необхідність структурних трансформацій у народногосподарському комплексі та його окремих галузях, а саме в залізничній сфері. Перетворення визначаються не тільки ринковими відносинами, а і вимогами рівноправного входження до європейської господарської системи.

В Україні ситуація напередодні рефрорми трохи інша: у довгостроковій тенденції обсяги вантажоперевезень зростають, якщо не враховувати обвалу в 2009 р., але та з тих пір потоки поступово відновлюються. Реальних конкурентів на цьому ринку в «Укрзалізниці» немає: вугілля та сталь, ключову номенклатуру вантажопотоків, як і раніше, вигідніше перевозити залізницею. А пасажиропотік тут узагалі щороку є стабільним. Але одна з головних наших проблем з польською все ж збігається: це глибокий знос основних фондів залізниць, які потребують негайного оновлення.

Система економічної безпеки кожної компанії суто індивідуальна. Її повнота і дієвість багато в чому залежать від наявної в державі законодавчої бази, матеріально-технічних і фінансових ресурсів що виділяються керівником підприємства, розуміння кожним із співробітників важливості забезпечення безпеки бізнесу, а також від знань і практичного досвіду начальника системи економічної безпеки, який безпосередньо займається побудовою і підтриманням в робочому стані самої системи.

Надійне забезпечення економічної безпеки підприємства в сучасних умовах - проблема для всіх організацій незалежно від фрорм власності, виду діяльності. 
Ринкова економіка, жорстка конкуренція в ній $є$ базовим джерелом виникнення економічних ризиків, загроз, небезпек, непередбачених ситуацій. Саме таке становище сучасності вимагає відповіді на поставлені питання: як уникнути впливу негативних загроз і ризиків; що зробити для того, щоб цей вплив був мінімальним; як ефективно управляти підприємством у таких ситуаціях; як досягти стабільного та безпечного стану в бізнесі.

\section{4. Інституціонально-економічні моделі поведінки підприємств}

За теперішнього часу, все більшої значущості набувають економічні умови функціонування держав різного рівня розвитку, серед яких особливої актуальності набуває економічна безпека. Натомість науковці часто досліджують тільки одну конкретну складову економічної безпеки. Така ситуація не є нормальною. Економічна безпека $є$ настільки важливою та комплексною проблемою, що недостатнє дослідження спричиняє загрози як безпосередньо в економічній діяльності людини, так і в політичній, соціальній та особистісній. Провідним суб'єктом економічної діяльності $€$ людина, тому ринкова економіка зумовлює новий погляд на ключову складову виробничої діяльності - людей. В умовах жорсткого конкурентного середовища підприємства поставлені в ситуацію необхідності «вичавлювання» максимального результату 3 наявних ресурсів, у тому числі людських. Людина, яка в результаті своєї діяльність реалізує об'єктивні суспільні відносини в світі, являє собою субстанцію суб'єкта, історія розвитку якого - це складне поєднання суспільного життя людей (форм виробництва, соціально-економічних, політичних структур) і всіляких духовних складових. Суб'єкт не може діяти без мотиваційних факторів, без психологічних складових діяльності. Більшість людей у звичайних, не екстремальних умовах $€$ гарними та порядними, але коли зовнішній світ або внутрішній стан змінюється певним чином, то дехто здатен так чи інакше зрадити інтересам професійної діяльності. Немає жорсткої закономірності між змінами внутрішнього та зовнішнього світу та 
непорядними вчинками. Але є певні тенденції. І якщо керівник підприємства або начальник служби безпеки навчиться визначати ці фактори, то цілком можливо, що захистить свою фірми від фінансових і матеріальних втрат, а когось із співробітників - від кримінальної відповідальності.

Рівень розвитку фрінансово-економічної діяльності підприємства залізничного транспорту, упровадження нових інфрормаційнокомунікаційних технологій у його функціонування, здатність генерувати та використовувати новітню інформацію, новітні знання, інноваційний рівень управлінців, працівників, персоналу в цілому стають запорукою його економічної безпеки. Причому інформація та знання в такому контексті - це щось більше, ніж просто їх накопичення: отримання інформації та знання про можливі небезпеки в економічній діяльності підприємства і їх імовірність передбачає їх використання для оцінювання ступеня схильності до цих подій і їх можливих наслідків, а потім - прийняття рішення управлінського складу підприємства, робітниками про те, як діяти.

Практика свідчить, що будь-які зміни для підприємства завжди націлені на отримання конкурентних переваг, створення та розвиток нових факторів конкурентоспроможності, адаптованих до нових умов. Глобалізаційні процеси, затяжні фрінансові кризи створюють комплекс загроз економічній безпеці підприємств залізничного транспорту. Здатність успішного вирішення головного функціонального завдання, а саме забезпечення необхідного обсягу перевезень, $€$ найбільш важливим критерієм оцінювання роботи залізничного транспорту. На успішне вирішення цього завдання впливає ряд чинників, перш за все, наявність потужностей для перевезень, що визначаються резервами перевезень, пропускними спроможностями, а також технічним рівнем рухомого складу. Але зазначені процеси спричиняють необхідність урахування якості та надійності людських ресурсів, що передбачає підвищені вимоги до формування персоналу - працівників, управлінців, з метою протистояння загрозам економічній безпеці підприємства. Тому вирішальним чинником зміцнення економічної безпеки підприємств залізничного транспорту є його кадровий потенціал [25, с. 255]. 
Таким чином, одним із чинників забезпечення економічної безпеки підприємства має стати певна система власної внутрішньої безпеки, спираючись на яку, підприємство буде здатним безперешкодно виконувати свої цільові функції. Провідною складовою такої системи $є$ відповідне кадрове забезпечення підприємства, наявність кваліфікованих кадрів, створення умов для надійності персоналу. Тому одним з обов'язкових аспектів діяльності такого складного комплексу, як залізничний транспорт, $€$ накопичення людського капіталу підприємства, що в умовах підприємства здійснюється за рахунок забезпечення відповідної освіти, підготовки кадрів, їх перепідготовки, підвищення кваліфрікації.

Таким чином, економічна спрямованість спирається на підвищення уваги до нематеріальних активів. Ідеться про такі активи підприємства, як професійні можливості, авторські права, інтелектуальна власність, патенти, ліцензії, бази, технології, а також навички та вміння працівників (знання, досвід, ноу-хау працівників, компетенції, організаційна культура, колективна позиція, партнерство). Такі засоби становлять ключові компетенції організації, які слід розуміти як вміння колективного навчання та досягнення конкурентних переваг на ринку праці.

Друга тенденція зв'язана з гуманістичною спрямованістю. Вона набула популярності в діловій практиці та домінувала в економічній літературі в 90-х рр. XX ст. Згідно із цим поняттям співробітники $\epsilon$ найважливішим і найціннішим активом організації. Людський фрактор можна розглядати як джерело конкурентних переваг підприємства, де співробітники з їх знаннями, досвідом, компетенціями та інтелектуальними та психологічними ресурсами утворюють нематеріальні активи, що використовують на користь підприємства. Виходячи із цього, засадничими положеннями такого підходу є гуманістична орієнтація, заснована на таких положеннях:

- важливою $€$ залежність між якістю людського капіталу та розвитком підприємства (підприємство має заохочувати та утримувати працівників);

- працівники залежно від ступеня задоволення своїх потреб (вимог, 
очікувань) взамін віддають у розпорядження підприємству свій індивідуальний інтелектуальний капітал (знання, компетенції, освіту, досвід, здоров'я);

- якщо підприємство знаходить компроміс між задоволенням працівників і своїми можливостями, створює умови для формування лояльності персоналу та підвищення мотивації кадрів до якісної праці, інтегрує цілі працівників із цілями підприємства, що впливає однаково як на індивідуальний розвиток персоналу, так і на розвиток в цілому суб'єкта економічної діяльності;

- людський капітал детермінує культурний профріль (ідентичність, особиста чи організаційна культура) і ринковий профіль підприємства.

За такого підходу в управлінні людським капіталом здійснюються наукові дослідження з управління на підприємстві, мотивування, планування кар'єрних сходинок, інвестування в працівників, кадрового маркетингу, організаційної культури, а також стратегії оцінок і аутплейсменту (від англ. outplacement).

Третій підхід, так званий змішаний, полягає в поєднанні двох зазначених вище. Інтеграція підходів заснована на практиці управління та пов'язана зі способом господарювання, спрямованим на постійне оновлення підприємства. Вона реалізується через комплекс процесів управління створенням, розповсюдженням і використанням знання, нарешті, підхід до врахування концепцій управління інтелектуальним капіталом, знаннями через залучення та контролінг, управління компетенціями та талантами.

3 огляду на різноплановість визначення інтелектуального капіталу, специфічну мережу зв'язків у його структурі, управління ним не є процесом легким.

Загалом з приводу використання терміна «людський капітал» на рівні корпорацій існує слушна думка, що концепції людського капіталу тісно пов'язані з концепціями інтелектуального капіталу, і їх часто плутають. Особливого значення надають інтелектуальному капіталу. У постіндустріальному суспільстві саме інтелектуальні здібності людини і їі 
освіченість великою мірою визначають як рівень доходів, так і соціальний статус [12, с. 64]. Інтелектуальний капітал - це більш широке поняття. До нього переважно включають сукупні знання, якими володіє організація в особі своїх співробітників, а також у вигляді методологій, патентів, архітектур та взаємозв'язків. Натомість, людський капітал - підмножина цієї концепції. Тому інтелектуальний капітал складається зі структурного капіталу та людського капіталу, враховує можливість майбутніх доходів 3 погляду внеску людини, їі здатності постійно створювати та породжувати ще більшу вартість [11].

Ефективне управління персоналом вимагає інвестування в освіту, перепідготовку, розширення доступу до інформації, пов'язаної 3 ефективністю праці, умов для розвитку здібностей і талантів працівників, відповідної заробітної платні тощо. Крім того, успішне управління персоналом вимагає систематичного оцінювання кожного працівника, а також ефективної системи винагороди за сумлінну працю.

3 урахуванням нових викликів та загроз, реального стану економіки, зокрема, залізничного транспорту України, необхідно вести пошук більш ефективних напрямів забезпечення економічної безпеки підприємства шляхом удосконалення кадрового менеджменту, що передбачає формування людського капіталу підприємств на основі прогресивних форм і методів роботи з персоналом. Застосування такого підходу до особи виражається в ії тлумаченні як джерела цінності, визнання її ролі як власника специфічних можливостей, що мають пріоритетне значення для стратегічної діяльності підприємства та його безпеки.

Тому в процесі змін, що відбуваються, професійні якості все частіше сприймають у контексті унікальних шансів використання ресурсів організації для фрормування позиції на тлі інших суб’єктів господарювання. Дослідники нечасто звертають увагу на здатність співробітників, управлінців до надійності в особливо складних та небезпечних ситуаціях у галузі залізничного транспорту. Важливим $€$ тлумачення сутності та визначення соціально-економічних тенденцій формування та розвитку персоналу підприємства залізничного транспорту, його надійності та 
безпеки як особливої якості їх професійної діяльності, що являє собою елементарні умови ефрективного протистояння небезпечним, кризовим ситуаціям в економічній діяльності підприємства, незалежно від прийнятих рішень, роботи в умовах підвищеного ступеня складності (небезпеки), яким $€$ залізничний транспорт.

Один із засновників теорії людського капіталу Г. Беккер визначив людський капітал підприємства як сукупність навичок, знань і вмінь персоналу. Як інвестиції в працівників він врахував витрати на освіту та навчання. Г. Беккер оцінив економічну ефективність освіти, насамперед, для самого робітника. Додатковий дохід від вищої освіти він визначив як різницю між доходами тих, хто закінчив коледж, і працівників із середньою загальною освітою. Разом із тим, практика діяльності підприємств свідчить, що багато керівників підприємств відмовляються від інвестицій у програми навчання персоналу, підвищення кваліфрікації, перепідготовку, оскільки усвідомлюють усі труднощі, пов'язані з визначенням повернення від таких інвестицій. Тому однією $з$ маловивчених сфер забезпечення економічної безпеки є освіта персоналу підприємства, його неперервне навчання та підвищення кваліфрікації.

Освітній сервіс сьогодні становить систему, пов'язану із широким комплексом управлінських дій, з розробкою нових економіко-математичних моделей, із застосуванням новітніх інформаційних технологій [20, с. 227]. Усе залежить від тієї атмосфери, яка склалася на підприємстві. У США застосовують своєрідну одиницю виміру застарілості знань спеціалістів «період напіврозпаду компетентності» - термін, який визначає тривалість часу з моменту закінчення ВН3, коли в результаті появи нової науковотехнічної документації компетентність спеціаліста знижується на $50 \%$. Зазначимо, що протягом останніх десятиліть цей період швидко скорочується. Наприклад, якщо для інженера випуску 1940 р. «період напіврозпаду компетентності» наставав через 12 років, для випускника 1960 р. - через 8-10 років, 1970 р. - через 5 років, то сьогодні ще менше. Згідно з результатами досліджень, щороку постійно оновлюється 5\% теоретичних та $20 \%$ професійних знань. Підраховано, що за останні 
25 років у США зі словника професій зникли 13 тисяч понять та з'явилося 11 тисяч нових [14, с. 210]. Зрозуміло, що та цей період змінюється швидкими темпами.

Усі розвинуті країни світу переходять на шлях накопичення інтелектуального людського капіталу, що забезпечує перехід економіки на інноваційний шлях розвитку. Наприклад, у Японії вже впроваджують перехід до загальної вищої освіти [23, с. 186]. Але просте накопичення знань і тільки професійна кар'єра припиняють бути пріоритетом. Фахівець мусить удосконалювати свої знання та вміння, оновлювати їх настільки, щоб мати змогу в разі потреби швидко та кардинально змінювати структуру діяльності. Передбачається, що в наступні 10 років $80 \%$ технологій стануть застарілими, а 80\% осіб, які зараз працюють, усе ще будуть працювати [23, с. 91]. Молоді люди, які зараз вибирають професію, не мають чіткого уявлення про те, на які робочі місця та заробітки вони можуть розраховувати в момент свого виходу на ринок праці.

Особливості процесу здобуття та використання знання визначають зв'язок індивідуума 3 організацією, інтелектуальний капітал якої він формує. 3 одного боку, працівник має потребу в організації, особливо внаслідок спеціалізації знання, яке може бути застосоване лише в організації та через організацію. 3 іншого боку, працівник кваліфрікованої праці, знання та вміння якого утворюють його унікальний капітал, значно відрізняється від звичайного промислового робітника. Його капітал (знання) і засоби виробництва (інтелектуальні інструменти аналізу, синтезу, моделювання тощо) ставлять його в становище внутрішнього підприємця. А науковці в інституційній теорії застосовують таке поняття, як «освітній капітал» [25, с. 257].

У сучасних умовах стратегія підприємства спрямована на реалізацію завдань, що спираються на використання знання, а також на перетворення їх на ціннісні складові підприємства. Такий підхід вимагає від управлінців виявлення інтер-дисциплінарного знання до розв'язання проблем у поєднанні з особистісними специфічними якостями. Нові високі вимоги до управлінського складу підприємства виявляються в поєднанні соціальних 
інтересів працівників, економічних (зиск, рентабельність), організаторських (здатність) та особистісних (здібності, талант) здібностей.

В управлінні інтелектуальним капіталом, так само як і в концепції контролінгу персоналу чи управлінні знаннями, цілями організації як цілісності $€$ повне використання засобів для їх залучення в процесі здобуття знання. У зв'язку із цим набуває актуальності така діяльність, як управління знаннями, що визначають у різноманітних аспектах діяльності підприємства, але частіше за все не відображають повною мірою суть цього процесу. С. Ілляшенко в комплексі складових економічної безпеки підприємства називає інтелектуальну складову, що характеризує інтелектуальний потенціал працівників підприємства. Негативні впливи на її формування пов'язані з втратою підприємством у своєму складі провідних висококваліфікованих працівників, що призводить до ослаблення інтелектуального потенціалу підприємства; зниження питомої ваги інженерно-технічних і наукових працівників у загальній кількості працюючих; спад винахідницької та раціоналізаторської активності; зменшення освітнього рівня працівників i, особливо, осіб апарату управління [11, с. 15].

Управління знаннями тлумачать як процес, завдяки якому підприємство генерує банк знань, капітал і інтелектуальний капітал підприємства[26, с.2]. Управління знаннями складається із чотирьох процесів: адаптації, екстерналізації, поєднання та інтернаціоналізації [27].

Разом із тим, визнання важливості економічної складової в управлінні знаннями надає можливість включити його до істотних чинників впливу на підвищення рівня економічної безпеки підприємства. Характер такої діяльності в значній мірі залежить від алгоритму організації навчання працівників. Він передбачає: на першому етапі, нагромадження знань і вмінь; на другому - відбувається процес реалізації та інтеграції знання, яке сприяє вирішенню проблем, що стоять перед підприємством. На третьому етапі відбувається практичне застосування нового знання в практичній діяльності колективу[29].

Управління знаннями складається з пошуку і отримання знання від 
зовнішніх партнерів, навчання від клієнтів, організації та трансферу знання в межах підприємства. Гнучка організація праці ґрунтується на положенні, що різноманітні групи фрахівців можуть одночасно співпрацювати між собою та користуватися тими самими знаннями. Управління знаннями - це систематичне та чітке керування його ключовими елементами. Крім того, в процесі функціонування підприємства управління знаннями здійснюється відповідно до шести процедур, а саме: утворення знання, накопичення знання, організація знання, розповсюдження знання, використання знання у внутрішніх структурних підрозділах, а також постійна визискування оперативних знань.

Управління знаннями визначається як процес фрормуванням певного комплексу специфічної діяльності та ініціатив, сприйнятих через суб'єкта господарювання 3 метою підвищення якості та обсягів організаційного знання.

Нерідко, щоб уникнути складності багатофракторного підходу, вчені, аналітики в описах, поясненнях економічних явищ не враховують психосоціальні чинники, від яких, насамперед, і залежить якість кадрового потенціалу підприємства, його людського та інтелектуального капіталу. Оскільки такі фрактори дедалі більше впливають на хід економічних процесів та їх результати, подібне абстрагування призводить до зниження достовірності аналізу, прогнозування, планування та ефрективності прийнятих рішень. У підсумку виграш від спрощень через недооцінювання чинників, пов'язаних з кадровими проблемами, людським фактором, часто менший, ніж витрати, що зумовлено реальною економічною дійсністю.

Таким чином, важливою метою дослідження $\epsilon$ пошук більш ефективних напрямів діяльності підприємства залізничної галузі в забезпеченні економічної безпеки підприємства 3 урахуванням нових викликів та загроз, реального соціально-економічного стану економіки, що передбачає, крім усіх інших заходів, удосконалення кадрової стратегії, формування людського капіталу підприємства залізничного транспорту на основі прогресивних форм і методів управління персоналом.

Персонал підприємства залізничної сфери, без сумніву, є одним із 
найцінніших ресурсів. Це люди і їх індивідуальна участь у виробництві, що визначає ефективність діяльності підприємства. Адже від управлінців підприємства залежить, чи буде оптимально використаний людський ресурс. Рівень складності планування роботи конкретних людей залежить від галузі, потужності команди, конкретного характеру завдань і масштабів підприємства. Так, наприклад, ефективність управління персоналом підприємства залізничної сфери вимагає скоординованих і професійних дій у складних умовах, що постійно змінюються. Тому ефективне управління людськими ресурсами має ґрунтуватися на вмілій оцінці компетентності персоналу підприємства, взаємному визначенні чітких цілей, ролей і обов'язків членів команди, а також справедливій винагороді за результати роботи.

До середини XX ст., коли в розвинених країнах були забезпечені високі стандарти споживання, розвиток технологій зажадав від людей, залучених у господарські процеси, не тільки першокласної освіти, а і творчих здібностей. Із цього моменту стимули та мотиви почали неминуче модифікуватися [9, с.62]. І специфічні особливості такої модифікації знайшли найбільше відображення в концепціях людського капіталу.

У межах такого підходу були здійснені наукові дослідження в галузі реструктуризації, раціоналізації зайнятості, оптимізації інвестицій у трудові ресурси, моніторинг, нематеріальний актив тощо. Економічна спрямованість людського капіталу підвищила увагу до нематеріальних активів. Таких як людські можливості, авторські права, інтелектуальна власність, патенти, ліцензії, бази даних, технології, а також до навичок та вмінь працівників (знання, досвід, ноу-хау працівників, компетенції, організаційна культура, колективна позиція, партнерство). Такі засоби визначають ключові переваги колективу організації, які слід розуміти як уміння доспільного навчання та досягнення конкурентних переваг на ринку праці.

Друга модальність зв'язана з гуманістичною спрямованістю. Вона набула популярності в діловій практиці та домінувала в економічній літературі в 90-х рр. XX ст. Згідно із цим поняттям, співробітники $\epsilon$ 
найважливішим і найціннішим активом організації. Людський фактор можна розглядати як джерело конкурентних переваг підприємства, де співробітники з їх знаннями, досвідом, компетенціями та інтелектуальними та психологічними ресурсами утворюють нематеріальні активи, що використовуються на користь підприємства. Виходячи із цього, засадничими положеннями такого підходу є гуманістична орієнтація, що заснована на таких положеннях:

Інтеграція різних підходів заснована на практиці управління і пов'язана із способом господарювання, спрямованого на постійне оновлення підприємства. Вона реалізується через комплекс процесів управління створенням, розповсюдженням і використанням знання 3 урахування концепцій управління інтелектуальним капіталом, знаннями через залучення та контролінг, управління компетенціями та талантами.

3 огляду на різноплановість визначення інтелектуального капіталу, специфічну мережу зв'язків у його структурі, управління ним є складним процесом.

Концепції людського капіталу тісно пов'язані 3 концепціями інтелектуального капіталу. У постіндустріальному суспільстві саме інтелектуальні здібності людини і її освіченість великою мірою визначають як рівень її доходів, так і соціальний статус [9, с.64]. Інтелектуальний капітал - це більш широке поняття. Інтелектуальний капітал складається зі структурного капіталу та людського капіталу і враховує можливості майбутніх доходів здатності людини постійно створювати та примножувати вартість [5].

С. Ілляшенко для вимірювання рівня інтелектуальної складової економічної безпеки пропонує такі показники, як: плинність кадрів високої кваліфрікації, питома вага інженерно-технічних і наукових працівників, показник винахідницької (раціоналізаторської) активності, показник освітнього рівня [8, с.15].

Інтелектуалізація праці та інвестування в співробітників сприяють формуванню характеристик і ключових компетенцій співробітників відповідно до потреб підприємства, що дає змогу підвищити 
конкурентоспроможність працівників та врахувати управління людським фрактором, що пов'язано з утворенням відповідного інтелектуального людського потенціалу на підприємстві.

Очевидно, що різні підходи різняться між собою, але всі вони належать до традиційних елементів управління людськими засобами, а їх поєднання сприяє розв'язуванню проблем у майбутній діяльності підприємства, а також прогнозуванню та адаптації підприємства до змін умов функціонування в майбутньому, що відповідає завданням забезпечення економічної безпеки підприємств залізничного транспорту. 3 урахуванням нових викликів та загроз, реального соціально-економічного стану економіки, зокрема, залізничного транспорту України, необхідний пошук більш ефективних напрямів забезпечення економічної безпеки підприємства шляхом удосконалення кадрового менеджменту, що передбачає формування людського капіталу підприємств на основі прогресивних форм і методів роботи з персоналом. Застосування такого підходу до персоналу виражається в тлумаченні його як джерела цінності, визнання його ролі як власника специфічних можливостей, що мають пріоритетне значення для стратегічної діяльності підприємства та його безпеки. Тому кожна з репрезентованих сучасних концепцій кадрового менеджменту розуміє людський капітал як ресурси підприємства, як стратегічний засіб, завдяки якому воно має можливості формування конкурентних переваг на ринку. Витрати на розвиток людського капіталу слід сприймати як довгострокову інвестицію підприємства у власну економічну безпеку, що приносить матеріальну та нематеріальну користь.

Становлення ринкових відносин зумовило трансформацію методів управління в організаціях, що поставило на перший план формування нової людино-центричної системи, в основі якої сама людина як найголовніший інструмент провадження ефективної діяльності підприємства. Людина впливає на всі аспекти життєдіяльності підприємства, є провідним фактором забезпечення економічної безпеки. 3 практичного погляду ринкова економіка надає людині широку економічну свободу, повертає їй право приватної власності, ефективність економічної 
діяльності ставить у жорстку залежність від особистісних характеристик господарюючого суб'єкта. Але це спонукало до формування в неї нової системи цінностей і норм, пов'язаних з економікою, тобто прийнятих у суспільстві та в його окремих груп стійких уявлень про те, які блага (багатство, зв'язки, влада, статус, різні види зайнятості, різні джерела та способи придбання доходу тощо) найбільш важливі або зовсім не важливі для них та їхніх сімей, а також уявлення людей про те, яка економічна поведінка для них переважна. Такі цінності багато в чому суперечать особливостям історично сформованого менталітету та типу економічного мислення громадян, що викликає деформації, деструктивну економічну поведінку людей, робить часто непередбачуваним процес вибору, психологічні установки та очікування, що перешкоджають економічній стабілізації. Тому ефективність економічних трансформацій в Україні багато в чому залежить не тільки від того, наскільки повно та правильно оцінено та враховано специфіку нашої країни, національного господарства, але ще і від особливостей психологічного складу її громадян.

Таким чином, уже недостатньо аналіз економічних процесів здійснювати на основі постулату про розвиток економіки тільки за власними об'єктивними законам. Серед сучасних економістів-теоретиків існує думка, що $50 \%$ економіки - це психологія. Це підтверджує принциповий курс світової наукової спільноти на інтеграцію дослідницьких програм різних наук про людину та їі діяльність (у контексті дослідження економічну). I, що найбільш важливо, саме визнання значущості психологічних характеристик індивідуальної поведінки професійними економістами ознаменувало та зафіксувало істотне зрушення в підходах і проблематиці всієї економічної науки. По суті, цей фракт означає визнання не тільки доцільності, а і необхідності виходу за межі формальних аксіоматичних моделей, слабко пов'язаних з реальною поведінкою, яку ці моделі покликані описувати. Про те, що економіка психологізована, свідчать такі суто економічні ситуації, як фрінансові паніки та інші форми колективної економічної діяльності, які дестабілізують фінансовоекономічні ситуації в різних регіонах світу та державах. 
3 погляду інституціоналізму, А. Ткач зазначає, що будь-які правила стають зіставними, якщо за основу брати і порівнювати таку їх характеристику, як витрати впровадження (або зміни) правила, розуміючи під витратами не тільки грошові витрати, а і усю сукупність зусиль економічних агентів, що включає психологічні витрати, а також необхідні для запровадження або зміни інституту витрати часу [24, с. 38].

Крім того, економіка достатньо політизована. Наприклад, надання позичок державам та компаніям не тільки під економічні, а і під політичні умови. Глобалізаційні економічні процеси спричинили макро- та мікросоціальні негативні наслідки: зростає рівень бідності та убозтва громадян, збільшуються економічна небезпека внаслідок військової ситуації на Україні та корупції, поглиблюються екологічні проблеми. Одна 3 провідних проблем України полягає в зрощуванні бізнесу та влади, унаслідок чого порушується розподіл функцій у державній системі, і вся держава пронизана корупцією. Тому прогнозування економічних процесів та їх розвиток, без врахування мотивацію суб'єктів господарювання, $€$ безперспективним.

Дж. Морено колись заявив, що настане час і коли-небудь, у наступному столітті, верховним ментором у Білому домі (йшлося про майбутнього президента США) має стати «психолог або лікар, який добре знає психологію людини» [14, с. 22].

На сьогодні в різних наукових дослідженнях (як економічних, так i психологічних) порушено проблему «економічної поведінки», «економічного мислення», «економічної свідомості», «економічного інтелекту», яких часто не вистачає людям, які приймають рішення в управлінській діяльності. Можливі різні тлумачення цих поняття, але всі вони тісно переплітаються 3 економічною та господарською ідеологією суб'єкта діяльності. Зазвичай під ними розуміють прагнення людини до економічної раціональності, здатності розподілу та споживання благ і послуг, розрахунку наслідків економічних рішень у процесі економічної діяльності тощо. Будь-яку діяльність людини можна розглядати як похідну від причин, мотивів, інтересів і намірів суб'єктів економічних процесів, під впливом яких 
формуються економічна поведінка і свідомість. Економічна поведінка залежить від багатьох причин (як об’єктивних, так і суб’єктивних).

Термін «економічний інтелект» має право на існування та в іншому контексті, коли йдеться про типології стилів господарювання, наприклад, про відмінність «економічної» людини та «соціологічної» людини.

Масштабність поєднання економічних і соціальних рефрорм у сучасних умовах кардинально змінюють економічну поведінку та свідомість сучасної людини.

Сучасне суспільство покладає на людину високий рівень відповідальності: готовність до усвідомленого вибору, прийняття рішень, особистої відповідальності, здатність до чіткої постановки мети, їі досягнення, раціональної поведінки, вміння діяти в певній ситуації, яка вимагає підвищеної компетентності. Це передбачає готовність людини до високого динамізму розвитку.

Він виявляється не тільки в прискоренні процесу оновлення професійних знань, умінь і навичок, а і у неухильному підвищенні ролі професійно важливих і ділових якостей працівників. Освіта, кваліфікація та рівень розвитку професійно важливих якостей виступають сьогодні основними якісними характеристиками суб'єктів економічної діяльності. Такими чинниками, вочевидь, і пояснюється те, що в розвинених країнах спостерігається тенденція до збільшення термінів тривалості навчання.

Як видно з табл. 4.1, це має позитивні наслідки, оскільки сприяє підвищенню Індексу розвитку людського потенціалу країни.

3 іншого боку, суспільні зміни сприяли перенесенню дорослішання людини на більш пізній період. Такий стан можна пояснити думкою американського вченого Е. Хофрфера, що «у часи великих змін учні наслідують майбутнє, а вчителі навчають жити в світі, якого ... більше не існує» [28]. Отже, для формування економічної поведінки людини, адекватної вимогам і викликам сучасності, необхідна відповідна освіта. Знання та навички, яких людина набувала в молодості, навчання в навчальних закладах більше не гарантують успіху в подальшому житті. Вони постійно оновлюються та змінюються. 
Таблиця 4.1

Індекс розвитку людського потенціалу та освітні компоненти деяких

європейських країн та України [28]

\begin{tabular}{|c|c|c|c|c|c|}
\hline P & Країна & $\begin{array}{c}\text { Середня } \\
\text { тривалість } \\
\text { життя } \\
\text { громадян }\end{array}$ & $\begin{array}{c}\text { Середня } \\
\text { тривалість } \\
\text { навчання }\end{array}$ & $\begin{array}{c}\text { Очікувана } \\
\text { тривалість } \\
\text { навчання }\end{array}$ & $\begin{array}{c}\text { Індекс } \\
\text { HDI }\end{array}$ \\
\hline 11 & Норвегія & 81,5 & 12,6 & 17,6 & 0,944 \\
\hline 22 & Австралія & 82,5 & 12,8 & 19,9 & 0,933 \\
\hline 33 & Швейцарія & 82.6 & 12.2 & 15.7 & 0.917 \\
\hline 44 & Голландія & 81,04 & 11,9 & 17,8 & 0,915 \\
\hline 55 & США & 78,94 & 12,9 & 16,5 & 0,914 \\
\hline 66 & Німеччина & 80,74 & 12,9 & 16,3 & 0,911 \\
\hline 77 & Нова Зеландія & 81,1 & 12,5 & 19.4 & 0,91 \\
\hline 88 & Канада & 81,5 & 12,3 & 15,9 & 0,902 \\
\hline 19 & Швеція & 81,8 & 11,7 & 15,8 & 0,898 \\
\hline 210 & Словенія & 79,6 & 11,9 & 16,8 & 0,874 \\
\hline 211 & Чехія & 77,7 & 12,3 & 16,4 & 0,861 \\
\hline 312 & Литва & 72,1 & 12,4 & 16.7 & 0,834 \\
\hline 313 & Польща & 76,41 & 11,8 & 15,5 & 0,834 \\
\hline 314 & Словаччина & 75,4 & 11,6 & 15 & 0,83 \\
\hline 415 & Угорщина & 74,6 & 11,3 & 15,4 & 0,818 \\
\hline 416 & Латвія & 72.2 & 11.5 & 15.5 & 0.810 \\
\hline$\ldots 83$ & Україна & $\mathbf{6 8 , 5 3}$ & $\mathbf{1 1 , 3}$ & $\mathbf{1 5 , 1}$ & $\mathbf{0 , 7 3 4}$ \\
\hline
\end{tabular}

Нові технології, розвиток комунікаційних мереж, глобалізація торговельної діяльності, зміни в соціальному та політичному житті суспільства - все це надає незрівнянно великі можливості для розвитку особистості, але водночас висуває до неї нетрадиційні вимоги.

Для умов виробничої діяльності на сучасному підприємстві характерні високий рівень невизначеності та непередбачуваності, необхідність прийняття рішень в умовах невизначеності 3 тяжкими наслідками в разі помилки (А. Азімов). Незадоволені потреби людини в економічних орієнтаціях породжують її ірраціональні дії, паніку, завищені очікування. Такі наслідки приховують у собі загрози, адже, наприклад, на залізничному транспорті більше ніж 300 тис. працівників цілодобово забезпечують його безперебійну роботу [25, с.67]. Тлумачення ірраціональної поведінки в економічних процесах, велика частина яких почала з'являтися в кризові 1970-ті рр., зумовили розрив з оптимістичною 
точкою зору на раціональний підхід, характерною для новацій 1950-х і 1960-x pp.

У табл. 4.2 відображено еволюцію моделей аналізу ризиків від нераціональної поведінки людини в уявленні різних авторів.

Таблиця 4.2

\section{Еволюції моделей аналізу ризиків від нераціональної поведінки}

людини

\begin{tabular}{|c|c|c|}
\hline $\begin{array}{l}\text { Дослідники методів } \\
\text { оцінювання ризиків }\end{array}$ & Джерела & Основні ідеї моделі \\
\hline Данієл Канеман & \begin{tabular}{lr}
\multicolumn{2}{l}{ «удження в умовах } \\
невизначеності» & в \\
співавторстві & с \\
А. Тверські (1978) &
\end{tabular} & $\begin{array}{l}\text { Неувага до механізму сходження до } \\
\text { середнього є не єдиною причиною } \\
\text { помилкових рішень }\end{array}$ \\
\hline Аймос Тверські & $\begin{array}{l}\text { «Судження в умовах } \\
\text { невизначеності» } \\
\text { (1978) }\end{array}$ & $\begin{array}{l}\text { Асиметрія між підходами до прийняття } \\
\text { рішень, спрямованих на досягнення } \\
\text { виграшу, і рішень, спрямованих на } \\
\text { уникнення програшу, є однією з найбільш } \\
\text { вражаючих знахідок теорії перспективи (i } \\
\text { однією з найкорисніших) }\end{array}$ \\
\hline Герш Шифринн & $\begin{array}{l}\text { «Економічна теорія } \\
\text { самоконтролю» } \\
(1981), \text { «ому саме } \\
\text { інвестори воліють } \\
\text { отримувати } \\
\text { дивіденди грошима» } \\
\text { (1984) }\end{array}$ & $\begin{array}{l}\text { Гіпотеза про подвійність людської психіки. } \\
\text { Ці дві частини нашої особистості } \\
\text { перебувають у постійному протидії }\end{array}$ \\
\hline Фішер Блек & $\begin{array}{l}\text { "Fact and Fantasy in } \\
\text { the Use of Options» } \\
(1975)\end{array}$ & $\begin{array}{lccc}\text { Розробка моделі } & \text { ринку } & \text { похідних } \\
\text { інструментів } & \text { (опціонів) } & \text { як } & \text { механізм } \\
\text { мінімізації ризиків } & & \\
\end{array}$ \\
\hline $\begin{array}{c}\text { Майрон Сембел } \\
\text { Шоулз }\end{array}$ & $\begin{array}{l}\text { «Податки і стратегія } \\
\text { бізнесу»у } \\
\text { співавторстві } \\
\text { М. Вольфсоном } \\
\text { (1991) }\end{array}$ & $\begin{array}{l}\text { Оцінювання опціону залежить від чотирьох } \\
\text { елементів: терміну його дії, цін, } \\
\text { процентних ставок і мінливості }\end{array}$ \\
\hline $\begin{array}{c}\text { Роберт Кархарт } \\
\text { Мертон }\end{array}$ & $\begin{array}{l}\text { «Фінансова } \\
\text { інфраструктура та } \\
\text { економічне } \\
\text { зростання»(1996); } \\
\text { «Глобальна } \\
\text { фінансова система: } \\
\text { функціональна } \\
\text { перспектива» } \\
\text { (The Global Financial } \\
\text { System: A Functional } \\
\text { Perspective) (1995) }\end{array}$ & $\begin{array}{l}\text { Похідні - це не угоди з акціями або } \\
\text { процентними ставками, або позиками під } \\
\text { заставу будинків. } \\
\text { В угодах } 3 \text { похідними інструментами } \\
\text { товаром є сама невизначеність }\end{array}$ \\
\hline
\end{tabular}

Американський економіст Р. Талер зазначає, що люди не $\epsilon$ ані «закінченими ідіотами», ані «надраціональними автоматами» [18]. Кожна людина вважає себе розумною істотою, здатною навіть у критичних 
ситуаціях розсудливо та обачливо застосовувати закони ймовірності для здійснення вибору, перед обличчям якого її ставить життя. Новаторські дослідження Р. Талера про те, як люди роблять вибір у реальному житті, значно відрізняються від того, у що вірили Бернуллі та Марковіц, розмірковуючи про корисність, раціональність і оптимальність. Але те, яким чином людина думає про себе, не завжди $€$ насправді. Наскільки їі уявлення про себе відповідають дійсності? Адже не можуть усі одночасно бути вище від середнього рівня? До того ж часто доводиться приймати дуже важливі рішення в складних, кризових ситуаціях, коли не вистачає часу оперувати законами ймовірності. Реальне життя часто ускладнює тло невизначеності поведінки всіх учасників - акторів ринку, про який говорив К. Eppoy [31].

На думку Л. Головкової, оскільки основні виробничі функції, пов'язані з реалізацією цілісного інноваційно-інвестиційного циклу, а саме «наука технологія - виробництво», розмежовані, для системи характерна застаріла лінійна функціонально-матрична схема. Вона не має досить розвинутих ффункцій, зворотних зв'язків, необхідного інформаційного забезпечення. Для неї є властивим значний вплив менталітету керівних органів, що сорормувався в умовах централізованої системи господарювання. Це не повною мірою відповідало вимогам роботи в умовах ринку [3, с. 38]. I надалі автор продовжує, що в ряді випадків продукція, яку виробляли підприємства України із зарубіжних комплектуючих при мінімальній заробітній платі, виходила на 10-25\% дорожчою, ніж імпортована. Ринкові механізми, які базувалися на існуючому нормативно-правовому полі, і кризовий стан значної частки підприємств унеможливлювали швидкий розвиток промисловості на принципах самоорганізації [4, с. 38].

Класична модель раціональної економічної поведінки людини (модель, на якій ґрунтується теорія ігор і більшість концепцій Марковіца) визначає, як актори мають приймати рішення перед загрозою ризику та на що був би схожий світ, якби люди насправді поводили себе відповідно до цього визначення. 
Проте, численні дослідження та експерименти доводять, що відхилення від моделі зустрічаються частіше, ніж ми можемо припустити.

Найбільш значні дослідження поведінки людей в умовах ризику та невизначеності були виконані двома ізраїльськими психологами Д. Канеманом та А. Тверські [28].

Ïх «теорія перспективи» відкрила своєрідні стереотипи поведінки, які ніколи не помічали прихильники раціонального прийняття рішень. Автори приписали ці стереотипи двом людським слабостям.

По-перше, емоції часто заважають самоконтролю, який необхідний для раціонального підходу до прийняття рішень. По-друге, люди часто не здатні ясно зрозуміти, із чим мають справу. Вони відчувають те, що психологи називають складністю усвідомлення чи когнітивним дисонансом.

Коріння складнощів багато в чому полягає у вибірці. Саме обмеженість вибірки змушує приймати рішення, у яких виявляється ірраціональність індивіда. Унаслідок цього люди схильні використовувати суб'єктивні методи вимірювання: Кейнсова складно-вимірність, хоча і поліпшена Р. Форбсом Харродом, «ступінь впевненості», «схильність до заощадження і ризику» фрігурують у їхніх рішеннях набагато частіше, ніж цілком вимірний «трикутник Паскаля», а інтуїтивні оцінки часто керують навіть тоді, коли вони думають, що використовуємо вимірювання.

Людину зазвичай розглядають як раціональну істоту. Наприклад, Д. Бернуллі описував раціональність як «природу людини», що спрощує завдання, оскільки розумна людська поведінка настільки ж передбачувана, як і природні явища, а можливо, і ще більше.

Д. Канеман і А. Тверські виявили, що оцінка ризикованої можливості виявляється більшою мірою залежно від точки відліку оцінки можливості виграшу чи програшу, а не кінцевої величини багатства, яким воно стане в результаті гри. Рішення визначається не тим, наскільки ви багаті, а тим, чи зробить воно вас багатшими або біднішими - так званим ефектом ментальності. Дослідження неприйняття невизначеності дозволяє припускати, що шлях до справжнього успіху можна побудувати за чужим рецептом, порушуючи правила [32]. 
В усіх випадках або тільки у випадкових іграх, люди воліють мати справу скоріше з відомими ймовірностями, ніж з невідомими. Стало очевидним, що люди віддають перевагу невідомим ймовірностям у тих ситуаціях, у яких вони відчувають свою компетентність, і відмовляться від тих ймовірностей у яких вони відчувають себе некомпетентними. На підставі цього був зроблений висновок, що неприйняття невизначеності породжує почуттям некомпетентності і виявляється, коли людина оцінює спільно ясні та туманні перспективи, але воно зменшується або зникає зовсім, якщо оцінює кожну перспективу окремо».

Поведінка людей у ході прийняття та реалізації рішень в умовах дії факторів невизначеності зовнішнього середовища та невизначеності майбутнього не була предметом наукового розгляду. Людину цікавила невизначеність майбутніх подій у вигляді статистичних результатів випадкових ігор, хвороб або ймовірна тривалість життя, тобто результати яких визначалися природою, а не рішеннями людини. Людину завжди розглядали як раціональну істоту (Д. Бернуллі описував раціональність як «природу людини»), що спрощує завдання, тому що розумна людська поведінка настільки ж передбачуване, як і природні явища, а можливо, і більше. Тому такого значення набуває поведінка людини з погляду економічної безпеки. Адже завдяки такій поведінці забезпечується безперебійне функціонування економіки, а саме підтримання основних показників розвитку, забезпечення високої ефективність діяльності 3 раціонального використання внутрішніх фракторів у розвитку, здатність ефрективно протистояти зовнішньому тиску, що сприяє прогнозуванню економічного зростання.

Формування психологічної готовності суб'єкта економічної діяльності має включати формування позитивного емоційного ставлення до неї. А це передбачає наявність відповідного мотиваційно-ціннісний компонента, чого досягають за допомогою: усвідомлення суб'єктом як позитивної соціальнопсихологічної, так і економічної ситуації; посилення мотивів економічної діяльності; формування потреб в ефрективній соціально-економічної самореалізації; усвідомлення особистісних і соціально-психологічних 
компонент успішності економічної діяльності (як показника відповідної компетентності); усвідомлення переваг психології партнерських відносин; формування мотиваційно-ціннісних характеристик суб'єктів.

Таким чином, економічна поведінка людини визначається сприйняттям, осмисленням і розумінням ситуації, в якій опинилася людина, і себе в цієї ситуації, тобто економічні вчинки людини можна проаналізувати, виокремлюючи три взаємопов'язані компоненти: когнітивний, афективний, конатиний.

Для формувального модуля характерні створення уявної експериментальної ситуації, обмежена множинність можливих варіантів вибору підприємницьких перспектив, вибудуваних відповідно до особистісних смислів, когнітивних стилів, ціннісно-мотиваційних та поведінкових рис суб'єктів.

\section{5. Розробка економіко-інформаційної системи економічної} безпеки

В реформуванні ринкової інфраструктури національної економіки, чільне місце в якій посідає залізничний транспорт, вимагає аналізу і оцінки його економічно-технологічного потенціалу, ефективності, стійкості, конкурентоздатності. Це потребує розробки нових підходів до методології та визначення основних напрямків оцінки економічного стану підприємств. Сьогоднішній стан підприємств залізниці характеризується погіршенням матеріально-технічної бази, різким збільшенням витрат на енергоресурси в собівартості транспортної продукції, погіршенням фрінансових показників діяльності.

Для розробки шляхів і методів реформування підприємств залізничного транспорту вирішальним $€$ визначення основних показників та методів оцінки реального стану їх господарської діяльності 3 метою досягнення такого їх рівня, що створюють умови фінансово-економічної безпеки їх діяльності.

В економічних дослідженнях існують різноманітні підходи до аналізу 
оцінки стану та шляхів реферування підприємств залізничного транспорту. В наукових публікаціях досліджені окремі проблеми реформування залізниці. Для їх комплексного вирішення важливо зробити оцінку економічного стану підприємства, зокрема Регіональної фрілії «Придніпровська залізниця» ПАТ «Українська залізниця» як системи.

Залізничний транспорт, як невід'ємна частина всієї економіки держави, повинен органічно увійти в ринкову економіку і забезпечувати стійке транспортне обслуговування підприємств національного господарства незалежно від форми власності, а також перевезення пасажирів. В умовах ринкових відносин залізниця повинна 3 достатньою економічною вигодою виконувати свої фрункції з тим, щоб утримувати в належному порядку свою матеріально-технічну базу, проводити інвестиційну політику з широким використанням досягнень науковотехнічного прогресу, а також соціальну політику, яка гарантує працівникам умови для зацікавленої і матеріально високозабезпеченої праці.

На сьогоднішній день для Укрзалізниці настав час реформ тривалих, серйозних, складних за своїм змістом. Суть цих рефрорм можна визначити таким чином: ринкові відносини, демонополізація, акціонування, приватизація. Серед першочергових завдань для створення базису реформ ставляться: нові принципи організації та управління перевізним процесом, вдосконалення транспортної інфраструктури, інфрорматизації та зв'язку тощо. Перші науково-практичні результати підтвердили правильність напрямків, обраних у якості первинних.

Для багатьох підприємств, на яких сьогодні відбувається реструктуризація, принципово важливі аналіз фінансових потоків, пошук вигідних джерел фінансування та інвестування, забезпечення фінансової рівноваги дебіторської й кредиторської заборгованості, ефективна податкова та облікова політика. Виходячи із цього, стратегію управління фінансовим потенціалом підприємства слід розглядати як комплекс заходів з управління фінансовими ресурсами підприємства 3 метою отримання економічної вигоди та безперервної життєдіяльності підприємства.

Механізм формування стратегії управління фінансовим потенціалом 
підприємства можна поділити на ряд етапів :

1. Аналіз і виділення пріоритетів підприємства при фрормуванні стратегії управління фрінансовим потенціалом.

2. Розробка конкретної мети базуються на:

- аналізі та прогнозі фрінансово-економічного стану зовнішнього середовища;

- аналізі внутрішнього середовища підприємства;

- виявленні сильних і слабих сторін, зокрема, сильними сторонами є: стабільний приріст обсягу продажів і прибутковості, додатковий грошовий потік; слабими сторонами - зниження рентабельності, негативний грошовий потік можливостей - поліпшення структури витрат; загрози втрата капіталу, інвестованого в дочірні підприємства, ознаки загальноекономічної депресії.

3. Адаптація до зовнішнього середовища.

4. Визначення основних напрямів фрормування, накопичення, розподілу ресурсів і пошук нових джерел фінансування.

5. Формування елементів стратегії управління фрінансовим потенціалом (планування й контроль за фінансовими потоками та ресурсами, організаційно-правове оформлення, вибір фрінансових інструментів, аналіз і оцінювання фрінансових ризиків, формування програми життєдіяльності підприємства, податкове планування).

6. Розробка стратегії управління фрінансовим потенціалом у конкретних фрінансових програмних документах і стратегічних планах.

7. Реалізація стратегії управління фрінансовим потенціалом.

8. Аналіз і контроль за стратегією управління фінансовим потенціалом. Використання результатів аналізу для конкретизації стратегічних напрямів розвитку підприємства.

Формування стратегії управління фрінансовим потенціалом підприємства включає такі складові :

- стратегічне й тактичне планування;

- організаційно-правове офрормлення фінансових потоків;

- контролінг в управлінні фінансово-економічною діяльністю; 
- вибір ефективних фрінансових інструментів;

- управління фрінансовими ризиками;

- податкове планування;

- використання інвестиційних рішень;

- діагностика та прогнозування фрінансового потенціалу підприємства.

Усі зазначені вище елементи стратегії управління фрінансовим потенціалом підприємства визначають конкурентоспроможність будь-якого підприємства. Досягнення саме цієї мети повинна забезпечити в перспективі система управління підприємством.

По суті, стратегію управління фрінансовим потенціалом підприємства слід розглядати як систему мети й дій на перспективу, основою створення та реалізації якої $€$ управління фрінансами, фінансовими ресурсами підприємства, тобто фінансовий менеджмент. Ця система є планами отримання, накопичення й розподілу фінансових ресурсів.

Вихідною позицією в розробці стратегії управління фрінансовим потенціалом підприємства $є$ ефективне використання фрінансового ринку, головною функцією якого $є$ забезпечення руху грошових потоків від одних власників до інших. Зокрема, необхідно активізувати систему вексельного обігу у взаємозаліках підприємств, розвивати лізингові відносини, упроваджувати факторингові операції тощо.

Реалізація механізму визначає управління фрінансовим потенціалом підприємства при врахуванні економічних ризиків як стратегічне управління фінансовим потенціалом підприємства при врахуванні економічних ризиків. Його дія залежить і від зовнішніх фракторів, що діють на рівень ризику: поточного стану зовнішнього економічного середовища, визначення ступеня небезпеки фракторів, що впливають на фрінансовий потенціал, державної макроекономічної політики й нормативно-правової бази.

При формуванні стратегічного механізму управління фрінансовим потенціалом підприємства з урахуванням економічних ризиків необхідно розглядати й процес стратегічного планування фінансового потенціалу як управлінську діяльність найвищого керівництва щодо визначення, 
формування та виявлення перспектив подальшого розвитку фінансових ресурсів і можливостей підприємства, страхування й управління економічними ризиками, а також головні цілі підприємства, за допомогою яких і будуть досягнуті поставленні завдання.

У процесі визначення критеріальної бази та розробки системи показників оцінювання фінансового потенціалу підприємства необхідно враховувати два механізми його функціонування, що, по суті, $\epsilon$ протилежними сторонами єдиного цілого й перебувають у тісному взаємозв'язку та взаємозалежності. На основі результатів дослідження ми пропонуємо комплекс цілей при формуванні фрінансового потенціалу підприємств з урахуванням економічних ризиків.

Сутність стратегічного управління фінансовим потенціалом полягає в тому, що на підприємстві, з одного боку, фрормується комплексна стратегія розвитку, а з іншого - структура управління будується так, щоб досягти поставлених фінансових цілей, що зумовлює створення механізму реалізації стратегії управління фінансовим потенціалом підприємства при оцінюванні економічних ризиків і факторів впливу на підприємство. Одним із кінцевих результатів стратегічного управління фінансовим потенціалом підприємства $є$ його конкурентоспроможний фрінансовий потенціал, що забезпечує сталий розвиток і подальші перспективи діяльності та запобігання виникненню банкрутства.

Система стратегічного управління фінансовим потенціалом підприємства при врахуванні економічних ризиків - це комплексна взаємопов'язана структура управління, спрямована на розробку загальних і довгострокових стратегічних фрінансових завдань підприємства, заходів запобігання ризику, програм дій, орієнтованих на перспективу, у межах яких досягають головної мети підприємства - забезпечення міцного фрінансового потенціалу підприємства.

Для досліджуваного нами підприємства необхідно виявити взаємозв'язок між фінансовими та стратегічними цілями підприємств із мінімізацією економічних ризиків на їхню діяльність, недопущенням можливого банкрутства та недоотриманням частки прибутку. 
Підприємства мають прагнути до загального зміцнення свого фінансового потенціалу шляхом зростання складових фрінансового потенціалу, оцінюючи вплив на них факторів ризику: потенціалу основних фондів, потенціалу фінансових ресурсів, потенціалу виробництва продукції та потенціалу кредитних можливостей. Саме визначені в дослідженні чотири елементи фрінансового потенціалу промислових підприємств забезпечують досягнення бажаного його рівня.

Принципово важливою при управлінні фінансовим потенціалом підприємства $є$ роль фінансових ресурсів, оскільки без них суб'єкт не досягне бажаної стратегічної мети. У цьому аспекті фрінансові ресурси становлять основу фрінансового потенціалу підприємства, оскільки стратегічне значення їх полягає, по-перше, у прихованих у них можливостях розробки оптимальної для суб'єкта стратегії (джерело формування); по-друге, у принципово можливому впливі на зовнішнє середовище підприємства (характер використання); по-третє, у специфіці стратегічної постановки цілей суб’єкта (напряму дій). Механізм стратегічного управління фрінансовим потенціалом підприємства при врахуванні економічних ризиків пов'язаний 3 постановкою цілей підприємства і підтриманням відносин із навколишнім середовищем, що дає йому змогу досягати своїх фрінансових завдань, мінімізувати економічний ризик і відповідає його внутрішнім фінансовим можливостям.

При формуванні стратегії управління розвитком підприємства необхідно застосовувати як кількісні, так і якісні підходи та методи. Необхідність поєднання кількісних і якісних методів породжує проблему їх обмеженого комбінування в процесі побудови стратегії.

Метод вирівнювання для інтегральної оцінки фінансового потенціалу підприємства використовують за правилом: чим ближче значення інтегральної оцінки до нуля, тим вищим $€$ фінансовий потенціал підприємства [1, с. 370$]$.

Розраховане значення інтегрального показника фінансового потенціалу підприємства дає змогу визначити місце порівнюваного підприємства в сукупності підприємств певної галузі. За допомогою методу 
вирівнювання даних визначають рівень відхилення показників окремого підприємства від еталонного, у якого значення інтегрального показника фінансового потенціалу найближче до нуля.

На рис. 4.2 наведено алгоритм виконання інтегрального рівневого оцінювання фрінансового потенціалу підприємства.

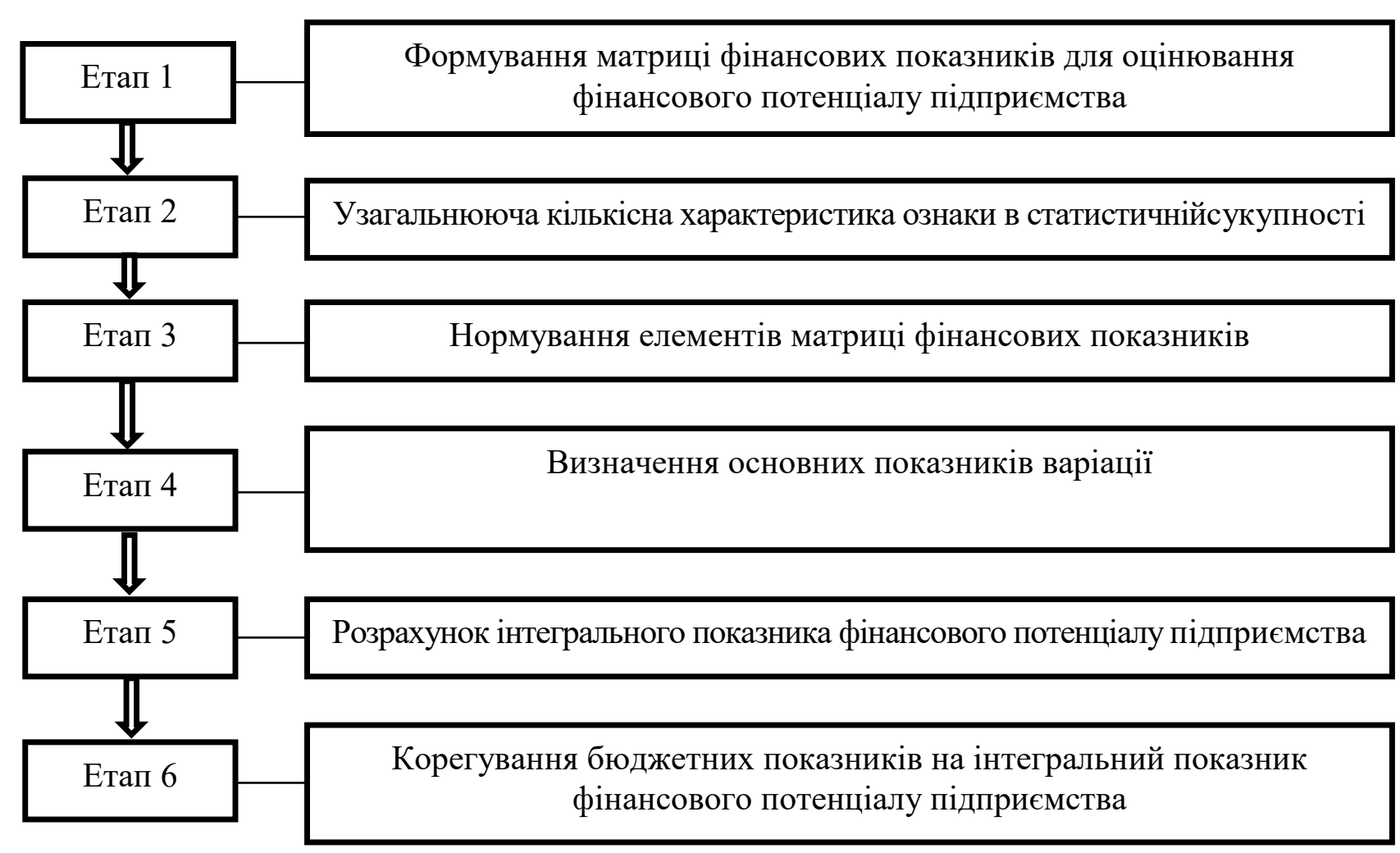

Рис. 4.2. Алгоритм виконання інтегрального рівневого оцінювання фінансового потенціалу підприємства

Математичний опис проведених досліджень виконують на основі методів варіаційної статистики з поєднанням зі стандартними значеннями вхідних показників, що використовують для оцінювання фрінансового потенціалу підприємства. Це дає змогу встановити зв'язок фінансового потенціалу 3 результатами фрінансово-господарської діяльності підприємства.

Для досягнення успіху підприємствам потрібна інформація стосовно їх ринків, клієнтів, конкурентів, виробничих процесів, фрінансових операцій. Спеціалістам, які приймають рішення, потрібна постійна, завчасна та 
змістовна інформація, яка надає їм можливість реагувати на зміни у їхньому бізнес-середовищі. Механізм, який використовується підприємством для запису, фрільтрування та підведення підсумків цієї інформації, називається Системою Управління Інформацією, або СУІ. Інформація, висвітлена в межах цієї роботи, підводить підсумок досвіду, відносно Системи Управління Інформацією (СУІ), набутого українськими компаніями, а також ключові аспекти будь-якої СУІ та як вони можуть бути використані для покращення виробничих процесів таких підприємств. Вона також описує засоби СУІ, які були розроблені для використання такими підприємствами.

Системи Управління Інформацією є дуже важливими, тому що якість кожного управлінського рішення залежить від керівництва, яке володіє точним освідомленням та розумінням ситуації, яка склалась, та вимагає рішучих дій. Для того, щоб прийняти найефективніше рішення, керівнику необхідна ефективно, зрозуміло та надійно подана правильна інформація. Це вірно для всіх рішень, але надзвичайно вірно для складних ситуацій, 3 якими стикається велика кількість українських керівників. Даний підхід базується на принципі, який вважає, що якісні управлінські рішення та дії можуть бути прийняті та впроваджені тільки при умові вчасної доступності надійної та актуальної інформації. Хоча, передумовою якісного прийняття рішення - $€$ постійне оновлення інфрормації.

Ефективна інформаційна система повинна задовольняти буденні операційні потреби в інформації, а також довгострокові стратегічні інформаційні потреби. Більш того, інформаційні потреби змінюються по мірі того, як розвиваються виробничі вимоги та проходять технологічні прогреси. Звіти управління, створені типовою СУІ, зазвичай, містять перегляд рентабельності компанії, прибутковості її окремого продукту або групи продуктів, детальний огляд експлуатаційних витрат різних відділів, запланованого продажу, та інформацію про частку на ринку. Щоб зробити можливим порівняння та оцінку діяльності, звіти повинні містити інформацію про попередні стадії, а також прогнозовані та бюджетні кількісні дані. 
Загальна мета всіх СУІ полягає в зниженні ризику, витрат та затримок, гарантуючи доступність правильної інформації.

Багато підприємств України успадкували деяку фрорму звітної системи ще з радянських часів. Це, зазвичай, звіти, які задовольняють постановлені законом вимоги (про податки, до пенсійного фонду та інших державних органів), ніж ті, що потрібні для прийняття управлінських рішень. Звітні системи радянської ери направлені на пред'явлення надзвичайно великої кількості інформації, але яка не часто може бути корисною і ще рідше, коли ви можете її отримати вчасно та на постійній основі. Таким чином, українські керівники змушені приймати неусвідомлені, неправильні та неефективні рішення, просто тому, що вони не мають доступу до потрібної їм інфрормації.

Системи Управління Інформації повинні повністю покривати діяльність компанії: від заготовки та виробництва до розповсюдження та продажу. Щойно ви переглянули потреби та ресурси, необхідні вашому підприємству, вам потрібно бути в змозі розробити Систему Управління, яка відповідає саме вашому середовищу. Ключова особливість даних систем полягає в тому, що вони не є єдиними та можуть бути застосовані в особливих обставинах конкретної справи.

Головною людиною, яка буде використовувати створені СУІ звіти, є генеральний директор підприємства. Керівники операційних відділів чи відділів продажу також матимуть бажання отримувати постійні поновлення інформації, хоча їм буде потрібна деяка інша інформація, ніж для генерального директора - більш детальна та залежна від ступеня їх відповідальності. Нарешті, належне корпоративне управління також вимагає від членів контрольного органу бути повністю інформованими про постійну діяльність. Контрольний орган, зазвичай, потребує інфрормації у формі висновків для того, щоб приймати виважені стратегічні рішення, ніж нав'язувати операційний контроль.

Головною вимогою ефективної Системи Управління Інформацією $€$ своєчасність. Небагато користі від створення точної інформації, коли ви вже ні на що не зможете вплинути, використавши її. 
Набагато більше користі від звітів, які можуть бути не наскільки точними, але доставленими своєчасно. Щодо звітів, як таких, вони повинні бути стислими, зрозумілими та легкими для читання. Використовуючи звіти відповідно до мети, заради якої вони були отримані, важливо впевнитись, що витрати на їх створення не перевищують одержаної в результаті користі.

Створення сучасної інтегрованої системи може бути досягненим одним з двох способів. Часто керівники, які приймають рішення, гадають, що розвиток повноцінної нової системи, використовуючи сучасну структурну систему, базу даних та інструменти на новій платформі, вирішить всі їхні проблеми. В той час, як даний підхід регулярно приймається, час, гроші та зусилля, необхідні для його впровадження, вимагають неабияких ресурсів. Зазвичай, впровадження займає від 1 до 3 років, тому очікування стратегічної користі може затягнутися. Інший підхід $€$ прогресивним та дає змогу швидкого отримання результату. Даний підхід залежить від прийняття системи накопичення інформації на базі поточних операційних систем. Щойно вигоди почнуть відчуватись, до платформи будуть додаватись зміни.

Розроблюючи Систему Управління Інформацією, важливо розуміти різницю між даними та інформацією. Всі відділи підприємства накопичують дані автоматично: від списку клієнтів до деталей про індивідуальні транзакції, затрати на сировину, чи на виробничі витрати. Але до тих пір поки дані не будуть зрозуміло класифіковані або проаналізовані та зібрані в сховищі даних, їх використання буде незначним та в неозначеному форматі. Аналізуючи, обробляючи та структуруючи дані в змістовний формат, ми створюємо ефективне сховище даних.

Керівництво підприємства відповідає за прийняття рішень і тому повинно бути рушійною силою в розробці будь-якої системи Управління Інформацією. Для цього, в першу чергу треба визначити, яка саме інформація потрібна, як часто та в якій формі слід її представити. Кожний запланований отримувач звіту СУІ повинен відповісти на ці три питання. Вам потрібно продивитись їх відповіді та вирішити, які ресурси вам треба 
використати для створення запланованих звітів. Як уже зазначалось раніше, існує значна різниця між внутрішнім (керівництво) та зовнішнім (встановлені законом) звітностями. Часто в Україні регулярні звіти подаються зовнішнім користувачам, звичайно державним органам. Такі звіти $€$ обов'язковими, а за невчасну подачу компанії підлягають штрафуванню. Але такі, встановлені законом, або фінансові звіти нав'язуються зовнішніми органами та не часто мають адміністративну цінність.

Ці засоби дуже цінні як такі. Але опорним пунктом в прогресивному підході $€$ розуміння того, як всі частини відповідають одна одній в логічно послідовному плані. Системи Управління Інформацією повинні звертатись до всіх рівнів операцій, планування, контролю та прийняття рішень компанії. Процес звітності починається на операційному рівні та просувається вгору до самого верху ієрархії підприємства. Іншими словами, дані накопичуються на операційному рівні, трансформуються в інформацію, а потім презентуються на стратегічному рівні. Дуже важливо, щоб всі ці системи та засоби накопичення інформації взаємодіяли в гармонійній системі. Це не значить, що не можливо мати доступ та використовувати інформацію на нижчому від Генерального Директора та Контрольного Органу рівні. Це можливо, і так повинно бути.

Встановивши ефективну базу для збору інформації, важливо далі автоматизувати методологію для перетворення цієї інформації в якомога кориснішу. Для того, щоб цього досягти, було розроблено засіб, який може бути застосований для інформації, яка зберігається в сховищі даних. Застосовуючи цей засіб, новий підхід управління може бути представлений швидко та без великих затрат. Даний засіб має назву: Панель Головних Вказівників, яка дає доскональну оцінку діяльності компанії, заздалегідь попереджує про негативні напрямки та визначає місце компанії в межах її промисловості.

Панель головних вказівників для кожного бізнесу окрема, так як бізнес відрізняється один від одного. Але принципи розробки засобу головного вказівника для бізнесу залишаються однаковими. 
Головні вказівники $€$ показниками якості діяльності відділу або організації в цілому, та досягнення ії̈ стратегічних цілей. Щойно розроблені, вони відстежують реальну діяльність компанії та підтримують її наміри.

Три головні функції, для яких слід встановити системи Управління Інформацією, - це планування, бізнес-контролювання та визначення результатів. Інформація, яку отримано з основних даних, використовується для фрормулювання стратегії та постановки цілей. Але, потрібно взяти до уваги порядок розвитку процесу; логічна стратегічна концепція не може бути розроблена без необхідних для цього фрактів. Ефективне планування таким чином залежить від всіх процесів, які йому передують, від збору та аналізу даних до формулювання стратегії, постановки маркетингових та формулювання цінової політики.

Цей засіб фрормує головні структурні елементи успішної СУІ. Його використання дає змогу керівництву приймати обдумані рішення, які базуються на сучасній інформації та необхідний для прийняття правильних рішень. 


\section{РОЗДІЛ 5}

\section{ФОРМУВАННЯ ІНСТИТУЦІОНАЛЬНОЇ МОДЕЛІ ОСВІТНЬОГО ПРОСТОРУ ОСОБИСТОСТІ}

\section{1. Умови формування інституціональної моделі освітнього простору особистості}

Простір і час у науці визначаються як основні всезагальні форми існування й руху матерії та визначальні всеохоплюючі умови буття й розвитку людини. У першому випадку людина включена до процесів природних ритмів і підкорюється закономірностям розвитку природних життєвих процесів. У другому - розвиток людини відбувається в соціумі, підпорядковуючись певному ритму й темпу, у якому змінюються покоління, життя наповнюється історичними подіями. Отже, розвиток людини відбувається у просторі, де вона стикається з конкретними умовами буття, i в часі власного життя, коли в неї виробляється суб'єктивне ставлення до них, до об'єктивно існуючого часу тощо.

Упровадження в усі сфрери суспільного буття інформаційних технологій відкрило людині можливості творити життєвий світ відповідно до своїх уявлень. Але цей світ є нерухомим і не переходить у реальність до тих пір, поки людина сама цього не захоче. Це відбувається тільки завдяки діям, діяльності, вольовим зусиллям, оцінкам і духовній спрямованості до віртуальних уявлень. Завдяки цьому людина, яка реалізує мрію, стає реальним учасником світу, його творцем.

У соціологічних науках поняття соціального простору розуміють як форму буття, існування. Соціальний простір - частина біосфрери, космосу й характеризується людським сенсом. Соціальний простір структурно неоднорідний і складається з багатьох підпросторів, що функціонально розрізняються. До сформованих останнім часом науковою думкою i практикою соціальних просторів слід віднести політичний, інституційний, правовий, технологічний, економічний, екологічний, інфрормаційний, 
культурний, психологічний, освітній тощо.

Виникнення цих соціальних просторів, вочевидь, пов'язане з новими реаліями сучасного світу, які потребують розроблення нового інструментарію, здатного адекватно відобразити його специфіку. Їх офрормлення відбувалося в міру розвитку людської спільноти, і вони 3 різною інтенсивністю впливають на розвиток глобального світу. Кожен із цих видів являє собою реально існуючий феномен, що включає низку характеристик того чи іншого виду життєдіяльності людини.

Соціальний простір людина відчуває через якості, зміна яких дає уяву про певні рухи у цьому просторі, про переміщення в ньому. Послідовну зміну якостей людина вважає за час, а діяльність, виконана протягом цього часу дає відчуття простору. Практично, фрізичних станів у таких умовах не існує. Астрономічний час змінюється на рівні неживої природи, коли ми фріксуємо його як різноманітні сонячні, місячні рухи, як співставлення рухів фрізичних тіл неживої природи. У такому разі відсутня складова людської природи. Такий час відносно людини абсолютний і об'єктивний. Але людина у своїй життєдіяльності визначає час відносно себе, він має особистісно значуще походження. Так само, простір (фізичний, особистісний) і час (астрономічний, особистісний) людина відчуває особисто, він нібито породжується у її відчутті. Це відбувається за допомогою подій, послідовність яких здатна відчути людина. I саме вона дає людині відчуття часу і простору. Така логіка дає можливість визначити особливості сприйняття соціального простору людиною, відчуття часу. Отже, у соціальному просторі послідовність подій можна прийняти за час. Проміжків між подіями людина не відчуває - за однією подією розпочинається інша, і така послідовність має пролонговану дію. Людина фріксує тільки події, але час, у який відбулася та чи інша подія людина фіксувати не здатна. Особливості уяви людини про простір виражені певними «психологічними» координатами (відчуття, сприйняття, уява). Сприйняття простору ґрунтується на реальних чи потенційних, але уявно спроектованих подіях, які можна класифікувати, відносити до різноманітних типів просторів, зокрема й психологічного. Тому поряд із реальним, 
фізичним простором дослідженню підлягає психологічно сприйнятий людиною перцептуальний простір.

Однією із підсистем соціального простору $є$ освітній простір, специфіка якого пов'язана з цільовими настановами освіти. Його особливістю $€$ його динамічність і відсутність меж, на відміну від середовища, що спричиняється систематичним зростанням обсягів знань, які передаються від покоління до покоління. Весь інформаційний простір, а не тільки освітні структури, формують людину. Просторова ідентифікація освіти $є$ умовою формування глобального мислення, тобто здатності людини вирішувати проблеми, які виникають у результаті об'єктивного розвитку суспільства. Світова спільнота намагається створити глобальну стратегію освіти людини незалежно від місця її проживання та рівня освіти. Сучасна освіта має стати міжнародною, а вища освіта $€$ основою полікультурного розвитку людини. Полікультурна освіта здатна забезпечити певну інформаційну безпеку розвитку, оскільки вона формує здатність оцінювати явища з позицій інших людей, різних культур, інших соціально-економічних формацій.

Упровадження терміна освітнього простору до світового наукового глосарію пов'язане з кількома факторами. Насамперед, актуалізація самої ідеї формування світового освітнього простору задає його логіку як соціального інституту на перехідному до постіндустріального етапу суспільного розвитку. Важливу роль відіграє й факт відмови від прийнятого в минулій освітній практиці уявлення про освітній процес як про певну лінію, канал, траєкторію, по яких нормативно має рухатися учень [186, c. 79].

Провідне поняття “простір" за допомогою означення “освітній” утворило термін “освітній простір”, яке, враховуючи смислове наповнення його компонентів, розуміють як певним чином упорядковану структуру, що характеризує всі освітні процеси, форми, траєкторії руху й виражає відношення між об'єктами та суб'єктами освітньої діяльності, забезпечуючи соціальну та особистісну значущість результату вдосконалення здібностей і поведінки суб'єктів цієї структури. 
Аналіз сучасної літератури свідчить про багатовимірність і різноплановість цього поняття, яке почало набувати самостійного змісту. Освітній простір розглядають як агреговану сукупність підпросторів, орієнтованих на різні категорії користувачів. Розрізняють кілька відтінків значення цього поняття: розвиток педагогічних технологій; власний простір суб'єкта освіти; дидактичний простір; концептуальний простір ціннісного прогнозування освіти; єдиний освітній простір людської цивілізації; синонім понять “соціально-освітній простір”, “духовно-педагогічний простір”, “виховний простір” тощо. Таким чином, зростання науково-технічного прогресу, динамізму, взаємозалежності та взаємодії окремих частин світу, глобальна інформаційна сфера докорінно змінюють характер суспільних і виробничих відносин. Змінюються і внутрішні умови функціонування відповідних структур. І всі вони пов'язані з розвитком освітнього простору.

Утворення освітнього простору як системного цілого зумовлене, поперше, реальними потребами, що виникли під впливом сучасного стану, історичної перспективи й розвитку світового загалу. Вони полягають у поглибленні взаємодії зумовленої прагненням до розширення економічних, культурних, політичних зв'язків у суспільстві. Адже саме вони найбільше сприяють тенденціям розвитку суспільства. По-друге, загостренням завдання оптимізації власної національної освіти. По-третє, нарівні 3 дискусіями щодо кризи традиційних підходів до проектування освіти нагальною залишається необхідність пошуку можливостей і умов відтворення позитивних моментів зруйнованого освітнього простору. Почетверте, створення освітнього простору зумовлене тими об'єктивними процесами, що відбуваються у світовій спільноті й передбачають необхідність інтеграції всіх зусиль для освоєння інфрормаційних, технологічних, економічних тощо просторів, що стає провідним елементом подальшого прогресу. I, нарешті, останнє - інтенсивне поширення телекомунікацій, Інтернету реально зміцнює взаємодію у сфері знань [52, c. 141].

У результаті зазначених суспільних явищ відбувається зближення та інтеграція культур, народів, соціальних систем. Інтегральний чинник 
суспільства перетворюється на активний фактор існування й розвитку людства, стає новоутворенням у вигляді просторової фрорми змісту людської історії та діяльності. Це збігається з думкою І. Фруміна про співвідношення змісту та форми. Вчений зазначає, що форма організації $є$ власне фрормою, коли стає способом виділення й акцентування певного змісту. Таке трапляється за умови, коли спосіб організації побудований і, головне, виражений так, що відділяє “те” від “не того”, причому це обмеження систематично й канонічно повторюється. Спосіб організації має виражати зміст, бути тією явною межею, перейшовши яку людина потрапляє в інший світ; таким чином, породжуються події буття, рух подій у світі. Породження подій - це й означає організовувати, надавати фрорму, перетворювати поведінку на “винахід”. У сучасному світі ця думка підтверджується стійкою тенденцією: суспільні інтеграційні процеси в наукових дослідженнях визначаються як фрормування й розвиток певного простору: економічного, інфрормаційного, освітнього, набуваючи при цьому форми взаємодії суб'єктів суспільної діяльності (соціальних інститутів) і змісту відповідного наповнення цієї діяльності.

Розширення освітнього простору пов'язане із “внутрішніми" й “зовнішніми” факторами. На нашу думку, до “внутрішніх" належить розширення освітнього простору під впливом нових досягнень науки, які сприяють створенню нових наукових сфрер, нових тем, розділів тощо. Наприклад, розвиток інформаційних технологій у системі освіти передбачає включення інформаційних ресурсів у навчальні програми. Створення якісно нового інформаційного середовища на принципах саморегулювання сприяє відкритості освітнього простору, розвитку інтерактивних фрорм взаємодії, впровадженню Інтернет-технологій. “Зовнішніми" фракторами розширення освітнього простору виступають нові технологічні та соціоприродні умови буття людини й суспільства, без урахування яких складно адаптуватися у динамічному світі. Найбільш очевидні з них - розвиток нових інформаційних і комунікаційних технологій, перехід до суспільства, яке засноване на знаннях, формування нової екологічної культури в результаті зіткнення інтересів індустріального 
суспільства та природи тощо. Загальним для всього зазначеного $\epsilon$ визнання зростаючої ролі знання та готовності вчитися й перенавчатися упродовж життя.

Освітній простір є реально наявним просторовим континуумом функціонування певних відносин у сфері змісту й організації освіти, що базуються на реальній інфрормаційно-директивній основі. Крім цього, до нього входять упорядковані, стійкі взаємодії особистості з відкритим соціальним простором, із сім'єю як інститутом освіти, із соціальними освітніми інститутами, орієнтованими на соціалізацію особистості, на формування здорових відносин у різних галузях їі життєдіяльності, між дітьми й дорослими, а також у соціумі навчального закладу. Чим більше впорядковані, систематизовані зв'язки між освітніми інститутами, соціальним мікросередовищем і особистістю, тим ширші можливості освітнього простору для формування творчої, морально багатої, соціально адаптованої особистості, створення умов для саморозвитку та професійного самовизначення.

Освітній простір особистості є її власним сутнісним уявленням про освіту як форму буття (взаємодії) у ній і як про процес, діяльність, явище, які пов'язані з освітою. Варто також зазначити, що освітній простір особистості $€$ результатом включення особистості в освітню діяльність, через яку вона установлює предметний чи комунікативний взаємозв'язок між власними освітніми потребами і способами їх задоволення. У такому разі освітній простір особистості $\epsilon$ інтегрованою взаємодією того, хто навчається і того, хто навчає в умовах, яка інституціалізована відповідним чином (формальним чи неформальним). Освітній простір особистості нами розуміється як певна можливість і джерело для організації освітньої діяльності, яка має особистісне значення. Такий простір $є$ певним результатом освоєння людиною соціального середовища, ступінь його пізнання, освоєння та присвоєння нею його можливостей на підставі суб'єктивного сприйняття, як простір можливостей, що дає змогу задовольнити особистісні потреби та інтереси.

У ролі масштабної одиниці освітнього простору виступає подія, 
пов'язана із освітою. Окремі події в межах освітнього простору особистості слід розглядати як процес руху до цілісності, як зміну її станів, положення, освітніх ситуацій тощо. В умовах виникнення освітньої ситуації, яка містить у собі смислоутворюючий потенціал, людина приймає рішення щодо вибору певної форми самовизначення та самоздійснення. Таким чином проявляється система цінностей особистості. Освітня ситуація у процесі руху до цілісності конкретизує схему освітнього простору на рівні окремої особистості. Саме по собі ставлення людини до власного освітнього простру, його усвідомлення і освоєння забезпечує становлення досвіду особистості як суб'єкта освітнього простору, вироблення особистісного знання, власної думки, свого світогляду, свого способу життя.

Отже, основна цінність просторового підходу до освіти полягає в його прагматичності. Він виникає з освітньої практики, щоб знову ж до неї й повернутися. Категорії освітнього простору, його компоненти, об'єкти та суб'єкти наповнені реальним практичним змістом.

Освіта за своєю природою перетворюється у подовжену протягом усього життя сореру діяльності людини, яка утворює освітній простір особистості. Така освітня діяльність поширюється не тільки на процес набуття загальної та фахової освіти індивіда, але й до всього тривалого періоду професійної та соціальної реалізації особистості. Освітній простір постає цілісною й динамічною системою умов творчого саморозвитку і самоздійснення особистості.

Сучасний стан освіти характеризується ї̈ перетворенням у подовжену протягом усього життя сфреру діяльності людини, а здобутки людства у галузі освіти стали основою для формування складної соціальної структури у вигляді освітнього простору. Останнім часом провідною функціональною тенденцією освітнього простору $€$ його розвиток у напрямі неперервності та всеосяжності, а його проектування зумовлене психологічними детермінантами, що супроводжують формування нового змісту, форм і характеру освіти. Нові знання перетворюються у генератор розширення простору розвитку особистості, стимулюють активність її самовизначення та самореалізації, сприяють 
більш успішному входженню в нові сфери творчої практики. Освіта стає більш гнучкішою та різноманітнішою. Формальна освіта вже не достатньо задовольняє людину, вона охоплює лише частину освітніх потреб та інтересів особистості, тому досить значна їх кількість знаходить втілення у неформальних освітніх інституціях. Трансформація освітнього простору в напрямі співіснування формальних і неформальних інститутів освітньої діяльності перетворює його в нову реальність життєдіяльності особистості.

Потреба в розвитку різноманітних форм освіти поставила перед наукою та практикою завдання розроблення стратегії освіти, що ґрунтується на оновленій інституційній структурі у вигляді освітнього простору особистості 3 його формальними та неформальними інституціями.

Проблема освітнього простору у психології окремо на тепер поки що не висвітлювалася, але у низці досліджень вітчизняних учених вона представлена в межах різних міждисциплінарних напрямів і психологічних підходів. Особливості формування освітніх цінностей та орієнтацій особистості досліджені у працях Б. Ананьєва, Л. Виготського, В. Давидова, С. Максименка, В. Петровського, С. Рубінштейна, Д. Узнадзе та ін. Концептуальні положення вивчення ґенези суб'єктної позиції людини щодо власної освіти здійснено в процесі дослідження психічного (розумового і морального) розвитку, які здійснили С. Максименко, М. Смульсон, Ю. Швалб. Існує нагальна потреба у психологічних моделях, психотехнічних засобах освіти, у поєднанні різних форм освіти (формальних, неформальних), у розвитку методології проектування. Водночас залишаються недостатньо вивченими багатоаспектні виміри неперервної освіти людини (lifelongeducation - освіта впродовж життя людини, lifewideeducation - всеосяжна освіта), яка перетворюється в подовжену протягом усього життя сферу діяльності людини і може бути визначена як "освітній простір особистості"; визначення місця особистості в інституційній системі освітнього простору (формальна, неформальна та інформальна освіта); така специфічна діяльність, як проектування, що є одним із ефективних засобів утворення освітнього простору поєднанням 
соціокультурної та особистісної складової; особистісно орієнтований та суб'єктний підходи до освіти, які ефрективно реалізуються в процесі проектування на перетині процесів розвитку, що відбуваються "природно", та штучно організованих ситуацій розвитку й саморозвитку цілісної особистості.

\section{2. Процес становлення інституціональної моделі освітнього} простору особистості

Важливими для дослідження освітнього простору особистості $€$ моделі, що відтворюють його інституційні та структурно-динамічні характеристики. Побудова таких моделей зазвичай асимілює теоретичні ідеї та основні концептуальні положення щодо реальностей освітнього простору, а це вможливлює пояснення й відтворення його проявів в структурних і динамічних аспектах.

Інституціалізація - це "заснування певних нових соціальних інститутів, правове й організаційне закріплення тих чи інших суспільних відносин"; інституційний - це "пов'язаний із соціальними інститутами, той, що має відношення до них" [36, с. 135]. Тобто соціальні зв'язки, які лежать в основі соціальних інститутів, називаються інституційними, а сам процес надання цим зв'язкам упорядкованого, нормативного характеру називається інституціалізацією. Інститут освіти як система є, з одного боку, оболонкою з окремих правових норм і правил, із дотриманням яких здійснюється освітня підготовка певного рівня, а з іншого - простором організаційних форм інституціалізованого процесу освіти.

Інституціалізація освітнього простору передбачає визначення характеристик змісту та форм інституціалізації освіти. Сучасна освіта стала одним 3 інститутів соціалізації, який фріксує все, що стало загальним, сталим правилом. Розвиток освітнього простору значною мірою здійснюється за рахунок розвитку різноманітних форм освіти. Критерієм рівня розвитку освітнього простору $є$ різноманітність і розвиненість наявних у ньому форм освіти, здатних надійно, на профресійному рівні задовольняти 
різноманітні потреби індивідів і соціальних груп, ефективно регулювати їхню соціальну поведінку.

Освітній простір як соціальний інститут є сукупністю статусів і ролей, соціальних норм, організацій (закладів, виробництв, університетів, академій, інститутів, фрірм тощо), що спираються на персонал, апарат управління й певні процедури. Інститут освіти виступає при цьому як засіб задоволення потреб суспільства у трансляції знань, соціалізації підростаючого покоління, у підготовці й перепідготовці фрахівців, у неперервному залученні людини до освіти впродовж її життя.

Таким чином, інституційний характер освітнього простору вимагає такого психологічного аналізу його теоретичних моделей, у результаті якого процеси та явища набувають нового психологічного змісту, поглиблюються й конкретизуються.

Суспільний розвиток потребує або створення нових теоретичних моделей, що могли б відтворювати живий рух тіла культури, або застосування цілеспрямованої редукції, коли вся повнота культури зводиться до свідомо обмеженої моделі для розв'язання конкретного завдання.

Одним із варіантів такого редукціонізму Ю. Швалб називає ситуаційний аналіз, коли сфера культури розглядається як відносно стабілізована "картинка", у якій можна штучно виділяти різні аспекти та складові [39]. За такого підходу соціокультурну ситуацію можна розглядати як наявний стан різних, відносно самостійних соціальних інституцій або сфрер. Причому проблема теоретичної "чистоти" при виділенні самих сфер відсувається на другий план - вони можуть просто стверджуватися як наявні. Автор пропонує виділити сфери освіти, науки, інформації (точніше, інформування), культури, дозвілля, побуту тощо. Об'єднати їх, на його думку, можливо тільки загальною дослідницькою рамкою у вигляді аналітичного опису або прогнозування соціокультурної ситуації (загалом або в кожній сфрері зокрема) у трьох аспектах: 1) як певне виробництво; 2) як сфреру діяльності людей; 3) як систему цінностей і норм. Виробничоекономічний аспект: саме у сфері культури люди задовольняють свої 
головні інтереси й потреби, а отже, витрачають готівку. Не випадково саме виробництво послуг, орієнтованих на вільний час і культуру, стало однією 3 перших і найприбутковіших сфер бізнесу. За своєю специфікою виробництво в соціокультурній сорері спрямоване переважно на виробництво послуг, а не товарів. Послуги визначають не зміст діяльності, а умови її розгортання. Чим вони гнучкіші та рухливіші, тим варіативніша сама діяльність і, відповідно, вищий рівень суб'єктивної свободи її здійснення. В освіті це виглядає таким чином. Розвиток системи освіти за останні десять років зумовив виникнення широкого кола навчальних закладів, що різняться змістом програм, цілями та методами навчання. Освітні послуги створюють для батьків і дітей можливість вибору освіти, форм і методів навчання, натомість колишня уніфікована система освіти такої можливості практично не надавала. Важливо те, що саме існування диференційованої системи освіти значно залежить від відповідності фрорм (послуг) запитам різних соціальних груп населення. Діяльнісний аспект: саме у сорері культури створюється можливість виходу особистості за межі нормативно визначених діяльностей і вимушеного влиття у сферу вільної творчості й саморозвитку. Відродження духовності, надання динамізму суспільному культурному розвиткові можливі тільки за умови переорієнтування культурної політики в напрямі підтримки їі конкурентоспроможності. Ціннісно-світоглядний аспект: суттєвою особливістю соціокультурних процесів $€$ те, що їхні зміст і форма знаходять реальне втілення й можливість розвитку тільки в разі включення в життя реальних людей. Кожна людина $є$ не лише споживачем соціокультурних послуг, а й носієм тих цінностей та ідей, що їх виражають. У цьому розумінні конкуренція в соціокультурній сфрері здійснюється не тільки стосовно грошей і часу населення, а й з приводу умонастроїв, цінностей та ідеалів, що переважають [39].

Згідно з описом таких параметрів, може бути побудований психологічний аналіз соціокультурних ситуацій. Різноманітні моделі освітнього простору дають змогу психологічної конкретизації таких ситуацій у вигляді психологічного аспекту структурно-функціонального аналізу 
освітнього простору. Завдяки сукупності структурних одиниць, що є носіями соціально-психологічних відносин, здійснюється фрормування інституційної системи освітнього простору. Структурність як системний принцип дає можливість опису системи шляхом виявлення ї̈ основних елементів, особливостей їхньої взаємодії та внутрішніх зв'язків, які й виступають як інститути та інституції.

Сучасний освітній простір перебуває у стані неперервних змін. Оновлення правил знищують чинне правило й уводять інше - повною мірою або частково. За таких умов фрормуються нові відношення між елементами, а також відроджуються ідеї минулих здобутків. Фактично ми спостерігаємо процес "розгортання" освітнього простору у вигляді формотворення нової соціальної системи. Тому інституціалізація виступає як одна із соціотворних складових соціального простору й відтворює інтелектуальний зріз еволюції суспільства. Таке розгортання визначається структурою культурних цінностей, що включає набір норм, правил, стандартів, які здійснюють вплив на людину, а також загальні ідеї, якими вона керується. Системи впливів здійснюються за допомогою формальних й неформальних правил та норм, що мають різний характер інституціалізації.

Засновник інституційного підходу в США Т.Веблен та його послідовники наголошували на провідній ролі психологічної складової поняття інституту. Вони вважали, що визначальною характеристикою інститутів $\epsilon$ поширення в суспільстві уявлення про відносини між особистостями й самим суспільством, їхніми функціями в суспільстві [8]. Головною гіпотезою Т. Веблена $є$ те, що соціальні, культурні, політичні й економічні події та інститути можуть зумовлюватися історичною сумою інстинктивної, невимушеної та сакраментальної поведінки людини. Порівнюючи людину з іншими видами живих істот, Т. Веблен вважає, що життя людини в суспільстві $€$ боротьбою за існування, а отже, процесом відбору та пристосування.

На рівні суспільства Т. Веблен зводить прогрес людської природи та інститутів до природного відбору найбільш пристосованого способу 
мислення та процесу примусового пристосування індивідів до навколишнього середовища, що поступово змінюється 3 розвитком суспільства й самих соціальних інститутів. Розвиток інститутів спричинює зміну структури суспільства, а також зміну критеріїв відбору індивідів. Причому відбір індивідів відбувається за принципом максимального пристосування складу характеру, звичок і темпераменту до змінного інституційного середовища. Таким чином, на думку Т. Веблена, утворення інститутів відбувається під впливом індивідуальної природи людини в результаті домінування психологічної складової.

Традиційна освіта завжди існувала у формі інституційної моделі, особливостями якої було чітке визначення відносин між ї̈ різними структурними елементами. Вирішальним фактором у формуванні й підтримці інституційної структури освіти дослідники називають звичку, що має властивість формувати частину пізнавальних потенцій індивіда. Таким чином, інститути стали розглядатися не як важливий фактор пізнавальних процесів, а як інструменти дослідження суспільних явищ, почали застосовувати методи когнітивної психології.

Зважаючи на наведене, інституційний характер освітнього простору визначається певною системою, що включає освітні структурні елементи та взаємозв'язки між ними, певний порядок організації і субординації інститутів. Будь-яка система, як цілісне утворення, передбачає наявність інтеграційного чинника, що є головним принципом її побудови. Цей фрактор відповідає основному принципу тієї сорери (підсистеми) дійсності, сутність якої повинна відобразити система. Система - це сукупність елементів, що перебувають у певному взаємозв'язку й відношеннях та утворюють певну цілісність. Характер системи визначають елементи, які детермінують їі, зв'язки між ними та ієрархія (певна підпорядкованість рівнів) її елементів.

Таким чином, утворення системи можливе лише тоді, коли у процесі функціонування сукупності певних елементів між ними встановлюються взаємозв'язки та певна субординація; а пізнавши ці зв'язки, можна встановити закономірності, що й визначають сутність системи. Узагальнену схему детермінації освітнього простору як системи подано на рис. 5.1. 


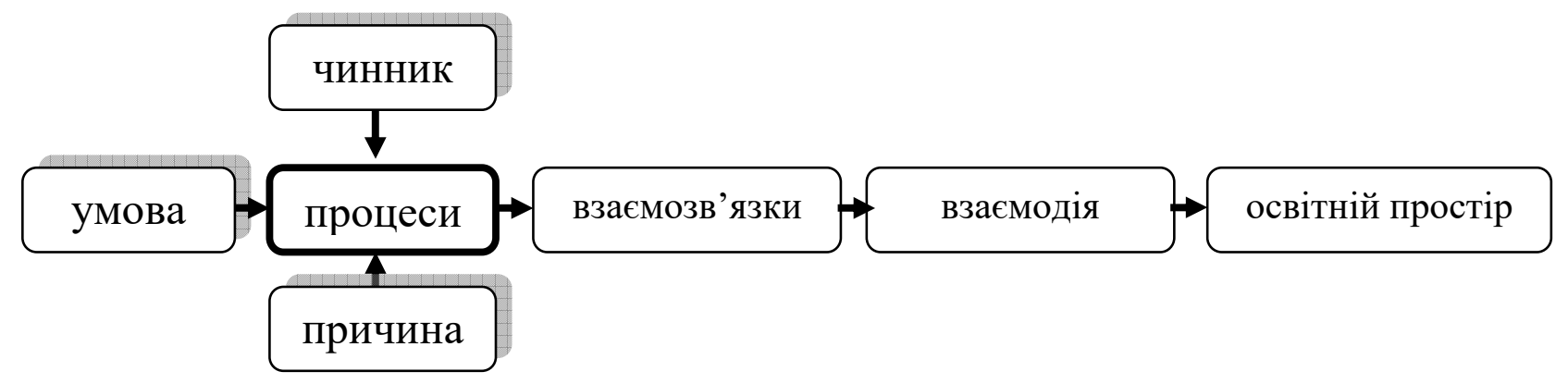

Рис. 5.1. Схема детермінації освітнього простору

В аналізі соціальної системи сучасна наука застосовує організаційну та інституційну структуру. 3 позицій інституційного підходу, найприйнятнішим $є$ розуміння інституційної системи як сукупності інститутів (правил i норм), що визначають організацію життєдіяльності всіх соціальних підсистем [36].

Нагляд за дотриманням прийнятих правил (примусом до виконання) здійснюють гаранти, тобто відповідні інституції (організації). Отже, сукупність індивідів, що взаємодіють на підставі певних правил і норм (інститутів) та інституцій (організацій), що забезпечують функціонування освітнього простору, утворюють інституційну систему освітнього простору, а його інституціалізація перетворює на активний компонент існування й розвитку людства, стає новоутворенням у вигляді просторового уявлення про простір людської діяльності.

Теоретик інституціоналізму У. Гамільтон зазначає, що інститути - це словесний символ для кращого позначення групи суспільних звичок. Вони означають переважний і постійний напрям думок, який став звичним для групи або перетворився для народу на звичай. У свою чергу, світ звичок $\mathrm{i}$ традицій, до яких ми пристосовуємо наше життя, являє собою сплетіння й нерозривне полотно інститутів $[8$, с.6]. Це твердження має глибокий психологічний зміст і повною мірою стосується сфери освіти.

Відповідно до інституційного підходу [36], під освітою (освітнім простором) будемо розуміти усталену форму організації суспільного життя, що включає суб’єктів освіти та установи (інституції), які наділені владними повноваженнями й матеріальними ресурсами для розроблення та 
забезпечення певних норм і правил (інститутів), соціальних фрункцій і ролей, управління й соціального контролю, у ході якого здійснюється підготовка, виховання, розвиток і соціалізація особистості з подальшим оволодінням професією, спеціальністю, кваліфікацією.

Інституційною ознакою освітнього простору ми вважаємо існування особливих освітніх інститутів і взаємопов'язаної системи організацій (інституцій), що обслуговують потоки освітніх послуг і контролюють їхню відповідність соціальним запитам особистості та суспільства.

Освітні інститути мають здатність розвиватися в межах освітнього простору під впливом соціальних та особистісних стимулів. Інституціалізація освітнього простору пов'язана зі змістом самого процесу і взаємодією формальних і неформальних правил в освітньому просторі.

На підставі наведених принципів і засад інституціалізації освіти нами була розроблена інституційна модель освітнього простору особистості (рис. 5.2).

До інституційної моделі освітнього простору ми включили формальне, неформальне та інформальне освітні середовища.

Формальне освітнє середовище утворюється сукупністю формальних правил, норм (інститутів) та організацій (інституцій), які в процесі взаємодії визначають соціальний характер функціонування освітнього простору. Сюди також належить законодавча база, що регламентує розвиток освіти в державі, профресійні спільноти, що взаємодіють у певному інтелектуальному просторі, популярні освітні теорії, що регламентують поведінку людей згідно з їхнім ставленням до освіти, навчальні заклади різних рівнів, дошкільні установи, музичні, художні, спортивні школи тощо, чинні міжнародні угоди з розвитку освіти тощо.

Відтворення суспільства здійснюється завдяки процесу інституційних змін, який має перманентний характер - час від часу виникають нові інститути. Але нові інститути як форма діяльності людей можуть виникати й функціонувати тільки тоді, коли будуть зрозумілими для людей, відповідатимуть певним схемам і значенням, якими люди володіють, тобто коли будуть затребуваними. 


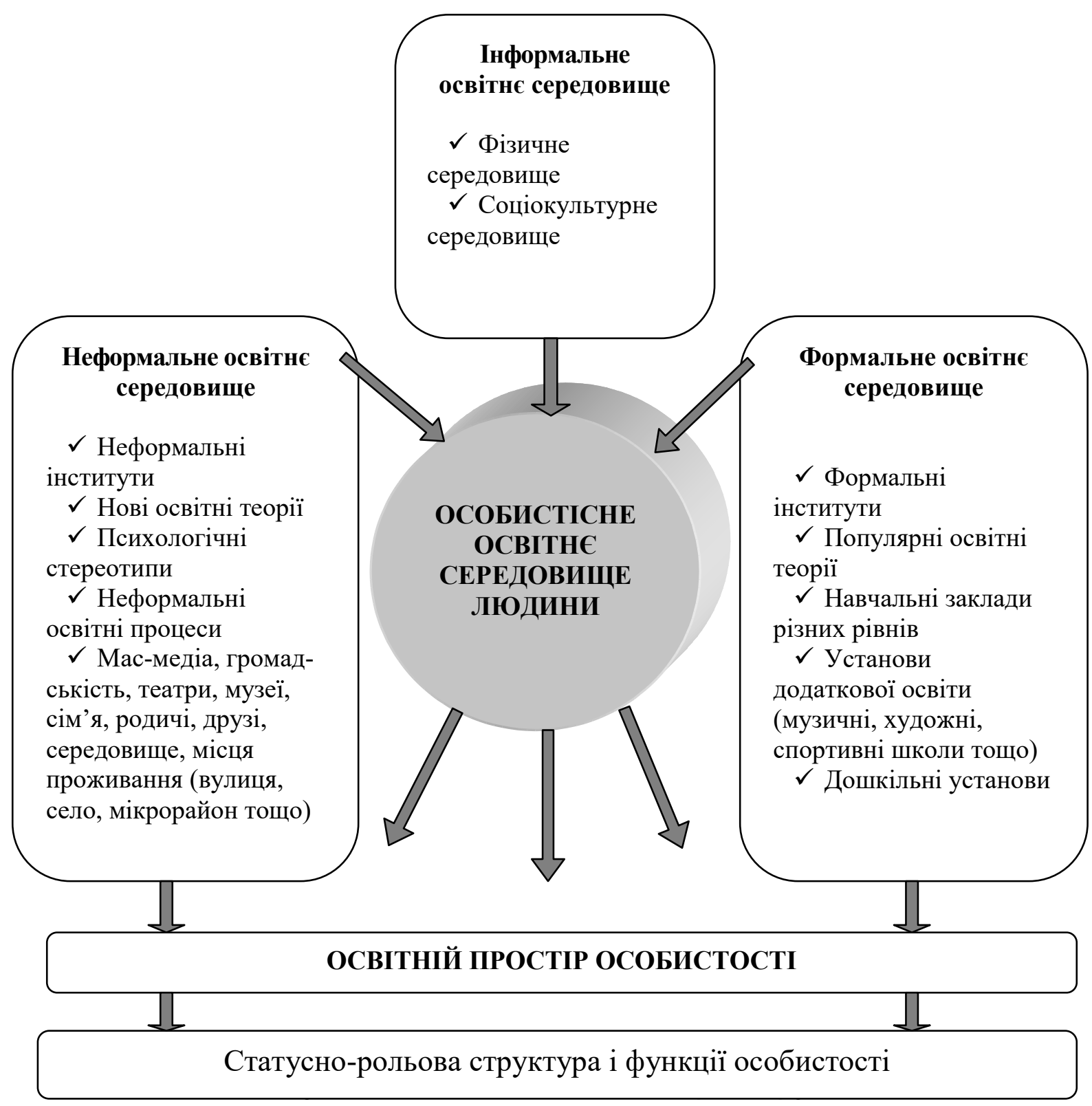

Рис. 5.2. Інституційна модель освітнього простору особистості

Такі смисли і значення, з одного боку, оформлюють і спрямовують наміри людини, а 3 іншого - надають певної цінності тим чи іншим зовнішнім умовам і обставинам її існування.

Тільки таким шляхом відбувається розуміння, завдяки якому можлива і здійснюється та чи інша людська дія. Знання, що мають найважливіше значення, для інституційного порядку в сумі являють собою "все те, що знає кожний" про соціальний світ, - це сукупність правил поведінки, моральних принципів, вірувань тощо, для теоретичної інтеграції яких необхідні інтелектуальні зусилля [4]. 
Інституціалізоване неформальне освітнє середовище утворюється неформальними освітніми процесами, пов'язане 3 існуванням неформальних правил, які існують у пам'яті учасників різних соціальних груп, у ролі гаранта яких виступає будь-який учасник групи, що помічає порушення, або сам індивід. Воно включає неформальні інститути, нові освітні теорії, що не набули типізації та об'єктивізації (тобто визнання в суспільстві), певні психологічні стереотипи й рутини, що утворюються спонтанно, домашнє навчання, репетиторство, мас-медіа, громадськість, театри, музеї, сім'я, родичі, друзі, середовище місця проживання (вулиця, село, мікрорайон) тощо. Таким чином, інституціалізоване неформальне освітнє середовище зв'язане з існуванням неформальних інститутів.

Для будь-якої людини властива спонтанність взаємодії з життєвим середовищем, під впливом якого вона залучається до освіти, тут вона оволодіває рідною мовою, культурними цінностями, фрормує переконання, менталітет, а також залучається до традицій, звичаїв та під їх впливом створює власні моделі поведінки. У такому процесі людина теж оволодіває певною освітою, яка називається інформальною. Неформальна та інформальна освіта починаються ще до школи, потім освіта переходить у стан фрормальної, а подальша освіта може відбуватись і фрормальним, і неформальним чином. Оскільки людина досить рідко задіяна лише в одному типі навчання, то відбувається явище конвергенції освітньої діяльності. Таким чином, неформальна освіта не $є$ опозицією до формальної.

Середовища формальної, неформальної та інформальної освіти, які інституціалізовані відповідним чином, утворюють інституційну систему освітнього простору. Освіта тут розуміється і як простір, і як інститут, у яких і через які людина формується як духовна істота; через освіту й освітній простір людина набуває можливості віднайти та зберегти себе у своїй самості, а з іншого боку - проектувати свою життєдіяльність і будувати їі за цим проектом відповідно до інституційних умов.

У цьому розумінні освітній простір може надати значну змістову й методологічну допомогу людині в пошуках власного образу, образу світу, 
способу життя тощо. Тому завершальною стадією інституціалізації $€$ створення, відповідно до норм і правил, чіткої статусно-рольової структури, яка соціально схвалена більшістю учасників цього соціального процесу.

Із неформальним та інформальним освітнім середовищем пов'язані форми організації дозвілля, вільного часу людей. На думку Т. Веблена, дозвіллєва цікавість створює нові стереотипи мислення й поведінки [9]. Сам по собі вільний час стає показником якості життя суспільства. У традиційних соціологічних та економічних теоріях вільний час операціоналізовували здебільшого як час, не зайнятий у виробничопобутовій діяльності та фізичній рекреації. Такий "залишковий" принцип завжди викликав безліч теоретичних заперечень, проте за умов соціально однорідного суспільства він був досить ефективним для проведення прикладних досліджень, але за умов соціальної диференціації він виявився недостатнім. Сучасні соціально-економічні умови життя різних груп населення спричинили значні відмінності психологічної структури ставлення людей до свого вільного часу й у засобах його структурування.

Вільний час особистості з психологічного погляду було описано Ю. Швалбом за трьома параметрами: це час, який особистість структурує й оформлює відповідно до власних світоглядних ідеалів, ціннісних орієнтацій та інтересів; упродовж нього діяльність і поведінка особистості потенційно не обмежені й мають індивідуально варіативний характер; це час потенційної можливості задоволення тих потреб особистості та реалізації тих її інтересів, які вона не реалізує в основній професійній діяльності. Ця обставина є причиною того, що діяльність людей у вільний час за формою та змістом утворює спектр від рутинно-одноманітних і фрактично беззмістовних форм до потенційно нескінченних за потужністю культуротворних процесів, котрі набувають як індивідуально-особистісного, так і суспільно-соціального змісту [39]. Зазначені підходи здебільшого реалізовуються в межах неформального інституціалізованого освітнього середовища.

Різноманітні інститути, такі як клуби, муніципальні центри, народні університети тощо мають освітні програми для громадян старшого віку. Але 
у наш час багато таких інститутів відчуває складнощі з фінансуванням. Люди похилого віку не мають можливості відвідувати освітні програми й отримувати задоволення від них. Та й не звикли, адже відсутня подібна практика. Але треба враховувати, що з року в рік зростає частка громадян пенсійного віку. У розвинутих країнах відсоток людей понад 65 років зріс з 8 до 14\% у 1950-х рр. і очікується зростання до 25\% у 2050 р. У країнах, що розвиваються, зараз менше 8\% людей віком за 60 років. До 2025 р. їх кількість збільшиться до 13\%, у 2050 р. - до 19\%.

Освіта впродовж життя людини - важлива стратегія, яка допомагає подолати проблеми віку в суспільстві. Найбільш важлива соціальна функція освіти - допомогти людині розвинути власний потенціал, навчити орієнтуватися в житті, осмислено реагувати на постійні зміни життєвого простору, оволодівати новими нормами і способами життя.

Соціальна форма освітнього простору не обмежується всім мислимим обсягом спеціальної інформації, притаманної певній сфері життя суспільства; вона може включати й такі силові лінії освітнього поля, які за своїм змістом перебувають далеко від сфери освіти, але здатні творчо збагачувати освітній процес. Не все людина знає і не все може контролювати, тому для неї так важливо мати вихід в інший простір, а потім повернутися назад із дещо іншим внутрішнім змістом, у межах іншого контексту для продовження власної освітньої діяльності. Людина впродовж життя постійно перебуває в ситуації вибору середовища, яке має бути сприятливим для неї як для суб'єкта професійної діяльності та, власне, життєдіяльності. Цей процес супроводжується певними втратами, творенням і відтворенням особистісного потенціалу людини, у результаті чого створюється індивідуальне освітнє середовище. Завдяки перетинам, поєднанням, гармонійним сполученням, взаємодоповненням усіх середовищ, у яких здійснюється життєдіяльність людини, забезпечується внутрішня цілісність життєдіяльності суспільства й окремої людини.

Різноманітні соціальні простори здійснюють свій "персональний" внесок в освітній простір і мають багато точок перетину та зіткнення. Проблема входження індивіда в інше середовище та створення власного 
передбачає звернення до проблеми адаптації, що розглядається на рівні макросередовища, яким $є$ світ профресії, і на рівні мікросередовища, що має дві форми: внутрішню (психічну) й зовнішню (профрільну). Результатом адаптації індивіда до макросередовища $€$ розвиток професійної самосвідомості, профресійної ідентичності, профеесійної культури; до внутрішнього мікросередовища - розвиток психологічної культури, суть якої полягає в гармонізації внутрішнього світу особистості, її особистісних і суб'єктних змінних. К. Левін розробив конструкт індивідуального поля в межах теорії поля [20]. В індивідуальній психології до життєвого простору входить не тільки навколишнє середовище існування людини, а і ї̈ несвідоме. А. К. Левін вказує на контекстуальність і рухливість усіх явищ внутрішнього світу людини. Психологічне середовище, яке людина відчуває як своє, дає їй змогу відмежуватися від світу предметів, соціальних і психологічних зв'язків, що утворюють фон, середовище життєдіяльності. При цьому стан межі власного психологічного світу значною мірою визначає ставлення людини до елементів середовища, тобто її ставлення до світу в цілому. Залежно від того, чи сприймається навколишній світ як чужий, чи як близький, детермінується й власна діяльність людини в ньому.

Інституціалізація освіти відбувається в межах освітнього простору, формує його конфігурацію та наповнює конкретним змістом. Найважливішою рисою інституціалізації освіти $\epsilon$ процес виявлення та встановлення (розроблення) конкретних правил і норм, відповідно до яких функціонують основні підсистеми освітнього простору. Вона визначає характер (правила) взаємодії, взаємовпливу, сутність самої системи освіти та її взаємодії з іншими підсистемами (економічною, культурною тощо) соціальної системи.

Базовим інститутом освітньої системи $є$ певний соціокод, що включає принципи трансляції накопиченого досвіду. Він здійснюється в різних формах. Тому освіта на кожному новому етапі свого інституційного розвитку послідовно втілює різні форми. Перехід від одного етапу до іншого відбувається кожного разу через нові засоби комунікації та інформаційної взаємодії (мова, писемність та інші засоби комунікації). 
Враховуючи сутність самого процесу інституціалізації, можна твердити, що саме в освіті, разом зі змінами в соціальній, економічній та інших підсистемах, створюються передумови для переходу до нового етапу цивілізаційного розвитку суспільства. Трансляція досвіду поколінь і створення нових рис людського й соціального капіталу, взаємодія на базі нових інститутів освіти творять нову інституційну сутність освіти, що формується у процесі проектування нового освітнього простору. Кожен новий виток цивілізаційного розвитку зумовлений соціальними (насамперед інституційними) змінами та $є$ передумовою й результатом формування нового змісту та форм освіти.

Освітній простір як підсистема соціальної дійсності конструюється його суб'єктами в процесі повсякденної діяльності. Сутність такого процесу зводиться до аналізу загального запасу знань. Суспільство виступає як продукт уречевленої людської діяльності, як сукупний запас знань, що конструюється індивідами у процесі взаємодії й закріплення соціального досвіду у вигляді інститутів - "об'єктивованих, наділених статусом фрактичної типізації дій і діячів" [2, с. 92]. У цьому контексті інститут та інституціалізація пов'язуються 3 аналізом об'єктивної реальності суспільства.

Освітній простір формується у процесі інституціалізації, тобто типізації або впорядкування соціального середовища (системи), створеного людиною в тій частині, яка $є$ відтворенням потреби в передачі та отриманні знань. Сама інституціалізація як явище має різні інтерпретації. Наприклад, Т. Лукман і П. Бергер, спираючись на теоретичні положення К. Маркса й А.Гелена, визначають інституціоналізацію як динамічний процес виникнення, встановлення й передачі соціального порядку, що включає три етапи: типізацію, об'єктивацію та легітимацію. Вони вважають необхідною антропологічною умовою типізації (тобто виникнення й суспільного визнання інститутів) хабітуалізацію (звикання), що має передувати власне інституціалізації та формувати її соціальної основи [4, с. 66].

Таким чином, інституційна модель освітнього простору особистості відображає закріплення системи освіти у вигляді різноманітних освітніх 
середовищ, спосіб їхнього структурування за допомогою встановлення соціального контролю, тобто об'єктивації інститутів і легітимації інституційного порядку. Внаслідок цього перша стадія інституціалізації розуміється як типізація діяльності членів соціальної групи. Друга стадія об'єктивізація, яка формується процесом історичного закріплення фрорм освітньої діяльності, що досягається завдяки їхньому відтворенню в поколіннях.

Освітній простір має нефізичний характер, адже він $є$ не результатом предметної, механістичної діяльності, а наслідком буття та свідомості людини, а також відповідних процесів. У наш час освітній простір перетворився на організаційний принцип теоретичної та практичної діяльності людини. Функціональність освітнього простору виявляється в розробці впорядкованого розмаїття інтелектуальної взаємодії та діяльності. Але оскільки життєдіяльність людини складається з різноманітних видів діяльності, які постійно оновлюються, взаємозамінюються (асимілюються), примножуються, інтегруються, диференціюються, то освіта $є$ і умовою, і похідною від діяльності людини.

Феноменом сучасності $\epsilon$ інституціалізація певних видів практик суспільного життя системою освіти, які раніше належали господарчопобутовій, особистій, а також сакрально-маргінальній сферам і традиційно не були інституціоналізованими. Ідеться насамперед про різні недержавні, факультативні освітні системи - курси, семінари, рекламні акції тощо. Курси дизайну інтер'єрів, макіяжу і створення іміджу, а також семінари із залагоджування сімейних конфліктів, тренінгів власної привабливості, вміння поводитися адекватно певним вимогам $€$ яскравим прикладом екстеріоризації й привласнення інститутом освіти не задіяних раніше навчальних практик через їх інституціоналізацію шляхом упровадження відповідних ліцензій, звань, свідоцтв, дипломів і подібних інституційних символів.

Можна говорити про екстенсивне розширення соціального поля освіти за допомогою залучення нових просторів людського буття, коли відбувається інституціалізація більшості просторових форм освіти. 
Таким чином, освітній простір - це, по суті, інституціоналізована й виокремлена в суспільстві система розвитку знань, що забезпечує зв'язок функціональних напрямів суспільної практики з механізмами суспільного відтворення, які підлягають постійному оновленню.

Освітній простір не має чітких меж, що відокремлюють його від інших просторів, у яких існує людина. Освітній простір, як система багатовимірна й послідовно структурована від макро- до регіонального й індивідуального рівня, є власне фрормально інституціоналізованою системою освіти, а також відкритою соціальною системою (неформальним інституціоналізованим утворенням).

Якщо характер інституційного устрою освітнього простору визначає діючі "правила гри", соціально-групова структура - принципи "організації команди", то людський потенціал відображає особистісні та професійні риси, ефективність комунікацій, уміння і здатність проявити волю. Найважливішим у цьому контексті $€$ структура цінностей особистості, їі потреб, інтересів тощо. Освітня траєкторія, побудована в цьому просторі, за певний проміжок часу фріксує напрямок якісної трансформації та змін особистості. А сполучення таких трьох вимірів забезпечує комплексну характеристику стану освітнього простору особистості як цілісного об'єкта.

Таким чином, розроблена модель освітнього простору особистості, інституційний рівень якого утворює система формальних, інформальних та неформальних освітніх елементів, що у своїй сукупності задовольняють освітні інтереси та потреби людей протягом усього життя Наразі освітній простір ще перебуває на стадії інституційного становлення і на окремих територіях, і в усьому світі. Його ствердження та розвиток відбуваються в напрямі фрормування інноваційних інтенсивно-процесуальних параметрів іншого часу - часу цивілізованого суспільного розвитку. У цьому полягає головна характеристика освітнього суспільства, у цьому єдиний сенс його існування - породження механізмів, що прискорюють якісні зміни особистості.

Засобами неперервної освіти (формальної, неформальної та інформальної) із застосуванням ресурсів наукової, професійної, побутової 
мови для вираження певних ідей, соціальних результатів, особистісного ставлення до власної життєдіяльності в умовах освітнього простору здійснюється певна взаємодія, а отже, освітній простір розглядається нами як комунікативна подія, яка відбувається між тими, хто навчається, і тими, хто навчає в певний час і у певному просторі. Установки особистості на неперервну освіту, змістовні освітньо-пізнавальні інтереси, мотивація особистісного зростання через освіту, ціннісні орієнтації, що пов'язані 3 принципами необмеженого саморозвитку та самовдосконалення ставлення до власної освіченості як життєвої цінності утворюють психологічний рівень (структура) освітнього простору утворюють:.

Дослідження змісту й напрямів інституціалізації нових світових тенденцій у розвитку характеру й ролі освіти свідчать про те, що нові соціальні імперативи відображають рух суспільства до відкритого, інформаційного, здійснюється перехід від техногенної до антропогенної цивілізації, з'являються нові принципи соціалізації особистості. Освіта віддзеркалює зміни в соціальних, психологічних, економічних відносинах. Інституціалізація в освіті означає виникнення нових і відмирання старих суспільних інститутів, правове й організаційне закріплення тих чи інших суспільних відносин, що проявляються в різноманітності фрорм. Просторові характеристики освіти свідчать про її значущі прояви творчості, які виражені в успіхах розвитку науки, новітніх технологій, розвитку суспільства, значних змін способу життя людини, розширенні їі можливостей тощо.

Інколи соціальна фрорма випереджає зміст, що призводить до кризових явищ в освіті. Можливо, на освітню систему України теж очікує нелегкий етап узгодження фрорми та змісту у зв'язку із входженням України до Болонського процесу.

Щоб запобігти виникненню соціально-психологічних суперечностей у процесі рефрормування освіти, необхідне інституційне проектування сучасних світових тенденцій розвитку освіти, урахування наявних і очікуваних переваг національної системи освіти, а також передбачення можливих наслідків і загроз. 


\section{3. Психологічні підходи до проектування в соціальних} системах

В епоху швидких соціокультурних змін трансформується майже все: від провідних форм виробництва до видів діяльності, буденних дій і звичок. Це зумовлено багатьма фракторами, але провідним $є$ зміна співвідношення між практично-предметною й розумовою діяльністю. Від початку 1970-х рр. науковці віддають перевагу останній, що найбільш чітко виявляється й фріксується в появі й бурхливому розвитку особливого та інституціоналізованого виду діяльності саме тепер - соціального проектування [1].

Одним із можливих засобів управління освітою $є$ проектування освітнього простору. Проектна парадигма в освіті набула інтенсивного розвитку на початку 80-х рp. XX-го ст. і знайшла відображення в дослідженнях учених-методологів М. Алексєєва, О. Асмолова, Ю. Громико,
В. Гуружапова,
В. Давидова,
E. Зeєp,
Ю. Машбиця,
В. Рубцова,

В. Слободчикова, Г. Щедровицького та ін. Поширення проектного підходу зумовило виникнення в освіті проектно-технологічного руху (В. Беспалько, О. Бондаревська, В. Гузєєв, М. Кларін, В. Монахов, Г. Селевко, І. Якиманська та ін.), у руслі якого особливу увагу здобули наукові праці, присвячені конкретним проблемам проектування в межах системомиследіяльнісної методології (О.Генісаретський, Ю.Громико, В. Розін, Г. Щедровицький, П. Щедровицький) та реалізації проектування як управлінської процедури (І. Бестужев-Лада, В. Ляудіс, І. Ляхов, Б. Сазонов, Ж. Тощенко).

Завдання методологічного забезпечення психолого-педагогічного проектування освітнього простору як умови розвитку особистості набувають пріоритетного значення, а переорієнтація освіти з формування особистості на проектування її розвитку й саморозвитку вже частково реалізується в особистісно орієнтованих гуманістичних наукових парадигмах, що знаходить відображення у психолого-педагогічних дослідженнях багатьох вчених (В. Сухомлинський, Г. Балл, О. Киричук, 
Ю. Машбиць, О. Прикот, В. Слободчиков, Г. Ільїн, Ю. Швалб). Окремої уваги заслуговує висвітлення нових наукових підходів щодо деяких аспектів психологічної складової розвитку освітнього простору особистості (М. Боришевський, Л. Карамушка, Н. Коломинський, С. Максименко, Ю. Швалб та ін.).

Наприкінці XX ст. провідні зарубіжні й вітчизняні дослідники (Д. Белл, П. Сорокін, Д. Нейсбіт, М. Моїсеєв, Е. Тофрфлер, представники Римського клубу та інші) констатували перехід у розвитку суспільства від індустріальної стадії до постіндустріальної [3; 24; 34; 38]. Зародження індустріальної фази знаменувалося появою феномена "проектності", який надає індустріальному світу динамічного, мінливого характеру. Цим самим закінчилася індустріальна фраза осмислення проектувальної діяльності, яка застосовувалася переважно в інженерно-технічній галузі, і розпочалося поширення феномену проектування фактично на всі види життєдіяльності людини. Наукове осмислення процесу й результатів проектування як специфрічного виду діяльності почалося на межі XX-XXI ст.

$\mathrm{Ha}$ той час зусиллями Г. Щедровицького, О. Генісаретського, К. Кантора був започаткований методологічний рух, пов'язаний 3 проектуванням [12; 41]. Це було зумовлено, з одного боку, необхідністю рефлексії досить розвинутих видів проектування, системного та організаційного проектування, а також застосуванням його в соціальній сфері, а з іншого - впровадженням проектування в інші види діяльності. Проникнення проектування в суміжні галузі, пов'язані з вирішенням складних соціотехнічних проблем, зумовило розвиток нових фрорм проектної культури, появу нових системних і методологічних орієнтацій, вихід на гуманітарні методи пізнання й освоєння дійсності.

Досить вагомий вклад у розвиток соціального проектування внесли дослідницькі проекти Римського клубу. Актуальність цих проектів була зумовлена кризовими ситуаціями в суспільстві, експоненціальним зростанням промислового виробництва, збільшенням народонаселення на планеті, забрудненням навколишнього середовища, проблемами забезпечення людей харчування. 
Римський клуб (Clubof Rome) - це міжнародна недержавна організація, діяльність якої спрямована на стимулювання вивчення глобальних проблем. Вона була заснована в 1968 р. італійським менеджером і суспільним діячем А. Печчеї. Основним "продуктом" діяльності Клубу $є$ його доповіді, присвячені глобальним проблемам i шляхам їх вирішення. Глобальні проблеми - це проблеми, які стосуються всіх країн і народів, їх вирішення можливе лише завдяки об'єднанню зусиль усієї світової спільноти, а від результату залежить існування земної цивілізації та її подальший розвиток. Тому Римський клуб зосередив усю увагу на розробці конкретних проблем майбутньої цивілізації "інформаційного суспільства". Проте, як слушно наголошує Ю. Хабермас, кваліфрікуючи сучасність як "незавершений проект", - в сучасному світі ще багато чого має бути зробленим, перш ніж говорити про можливості постсучасного світу [43; 44].

Учені висловлювали припущення, що подібно до того, як можна спостерігати та створювати системи, так само можна розробляти й різноманітні соціальні проекти. З'явилися спеціальні дисципліни й підготовка фрахівців із соціального проектування, управління проектами тощо. Така ситуація вимагала фрормування проектної культури комплексної, інтегральної характеристики проектувальної діяльності. Вона передбачає певну суму знань, умінь, навичок, компетенцій, наявність цінностей та ідеалів, системи орієнтацій і установок, норм і принципів проектної діяльності, проектний стиль мислення, особливе бачення фізичного й соціального простору життєдіяльності людини. Завдяки тому, що проектна культура виступає органічним елементом і професійної, i загальної культури, досить популярною стала думка про суспільство, яке вже досягло постіндустріальної стадії, як про суспільство проектної культури.

Соціальний проект спрямований на вирішення проблем соціального передбачення, прогнозування, планування, конструювання й моделювання. Соціальний проект - це "мета проектної діяльності як виду соціальної творчості. Основною метою соціального проекту є створення оптимальної 
спільноти організованих колективних відносин із досвідом об'єктивних умов і життєдіяльності різних соціальних груп" $[19$, с.11]. Таким чином, у широкому розумінні соціальний проект - це модель самої людської діяльності, спрямована на зміну соціальної ситуації.

Соціальний проект інноваційного характеру відкриває нові "життєві світи" (термін упроваджено Е.Гуссерлем, засновником феноменологічної філософії) - світи в їх значущості для життя людини, світи соціальної взаємодії, багатство досвіду людини [108]. У сфрері соціального знання поняття "життєві світи" підкреслює проблему взаємодії, дії та усвідомлення цієї дії, взаємозв'язку як вираження єдності установок засобами об'єктивізації ситуації (А. Шюц) [48]; отримує обґрунтування взаємозв'язок етапів соціалізації індивіда як перехід від "природної установки свідомості до життєвих світів як результату феноменологічної редукції"(П. Бергер, Т. Лукман) [17, с. 169].

Поняття "життєвий світ" в інтерпретації Ю. Хабермаса розвиває далі ідеї феноменологічної соціології й застосовується ним на позначення непроблематичного "фону" будь-якої життєвої ситуації. Конфлікти між "життєвим світом" і структурою "системи" Ю. Хабермас вбачає у сфрері соціальної взаємодії, у прояві не інституційних протестів, в існуванні альтернативних способів життя. "Життєвий світ" і "система" - це різні способи розгляду суспільства, які доповнюють один одного; їхня взаємодія обґрунтована свідомістю власної логіки функціонування. Логіка "системи" це "інструментальна" раціональність. Логіка "життєвого світу" комунікативна раціональність [17, с. 169; 46].

Отже, до соціальних систем увійшла ідея проектування як принципу програмування майбутнього соціального середовища людини. Переваги проектного підходу вбачаються в незалежній здатності мислення й діяльності, їх самостійності, соціальній значущості щодо впровадження в життя й застосування в практичній діяльності фрілософського та методологічного осмислення. Проектування відрізняється від наукової й виробничої діяльності та охоплює всі ланки соціальної діяльності, включає науку, соціальне планування, економіку й освіту [23, с. 137]. 
Активний розвиток проектування в соціальних системах зумовлений тими змінами, які відбуваються в суспільстві; найвагомішими з них є ті, що відбуваються з людиною. Тому виникає потреба зрозуміти, наскільки та яким чином людина здатна сприймати ці зміни, щоб успішно пристосуватися до нових умов життєдіяльності, яким чином з її відносно обмеженими можливостями переробляти, трансформувати й перетворювати величезні масиви інформації, знання та навички.

Наслідком цього $є$ виникнення у процесі проектування версій чи варіантів розвитку, змін певного явища. Щоб чітко осмислити суть проектування, необхідно співвіднести його з близькими за змістом і значенням поняттями.

Такими $€$ поняття планування, передбачення, прогнозування, конструювання, моделювання. Якщо планування - це науково і практично обґрунтоване визначення цілей, завдань, термінів і пропорцій розвитку того чи іншого явища, його реалізації і перетворень в інтересах суспільства, то передбачення спирається на виявлення закономірностей розвитку явища чи події, коли відомі причини його зародження, форми функціонування і хід розвитку, це уявлення людини про майбутнє. Прогнозування ж, у свою чергу,- це одна із фрорм передбачення, яка виражена в цілепокладанні, програмуванні й управлінні запланованим процесом явища на основі виявлених параметрів його виникнення, існування, сталих форм і тенденцій розвитку. Воно пов'язане з передбаченням напрямів розвитку явища в майбутньому шляхом перенесення на нього уявлення про те, як розвивається сучасне явище. Таке перенесення здійснюється за допомогою екстраполяції, моделювання та експертизи і виражається в аналізі прогнозного фону, формуванні первинних прогнозних і нормативних моделей, обґрунтуванні й оцінці пошукових прогнозів.

Природними фракторами у процесі проектування слугують закономірності розвитку й функціонування проектованого об'єкта, які визначаються його сутнісною природою. Штучними факторами є моделі, які дають змогу уявити майбутнє об'єкта. Ці два чинники повинні бути узгодженими для проектованого об'єкта. 
А розвиток об'єкта має розглядатися як складний штучно-природний процес. Такий підхід до проектування трансформує його в управління розвитком проектованого об'єкта, і проектування тоді розглядається як засіб і форма цього об'єкта. Після закінчення проектного циклу в об'єкті відбуваються зміни, які вимагають нових проектних досліджень і розробок. Процес проектування стає неперервним, континуальним (за А. Брушлинським - недиз'юнктивним) [6, с. 205], на відміну від інженерного, який є дискретним (диз'юнктивним) проектуванням .

У середині 1930-х рр. М. Берштейн підсумовуючи дослідження відсутності зв'язку між іннерваційними командами й рухами як їх результатами констатував, що у процесі вирішення завдань до мозку людини постійно надходять сенсорні відомості про вже досягнуті проміжні результати, які порівнюються 3 кінцевою метою рухів. М. Бернштейн змушений був увести таке поняття, як модель потрібного майбутнього, яке фіксувало необхідність існування в мозку передбачення кінцевого результату певної діяльності в певній кодованій фрормі. У ході подальших досліджень учений почав застосовувати терміни "моторний образ", "проект руху" [5, с. 281]. Життедіяльність кожного організму $є$ не тільки врівноваженням його із середовищем та з потоком стимуляційних впливів, що припадає на нього, а й активним подоланням середовища, що визначається окресленою раніше моделлю потрібного йому майбутнього [5, с. 456].

Історично проектування належало переважно сфері інженерії, потім на його основі у вітчизняній і зарубіжній практиці управління виникла й розвивається вже не одне десятиліття соціальна інженерія. Соціальна інженерія (socialengineering) - це сукупність підходів прикладних соціальних наук, орієнтованих на цілеспрямовані зміни організаційних структур, що визначають поведінку людини. Вона $є$ складовою соціології і претендує на сукупність тих специфічних знань, які спрямовують, упорядковують та оптимізують процес творення, модернізації й відтворення нових ("штучних") соціальних реальностей. Певним чином вона "добудовує" соціологічну науку, завершує ії на фазі перетворення наукових знань у моделі, проекти 
й конструкції соціальних інститутів, цінностей, норм, алгоритмів діяльності, відносин, поведінки тощо.

Соціальна інженерія $€$ комплексом практично орієнтованих знань у галузі управління соціальними структурами й процесами. Ії̈ розвиток відбувається за такими напрямами:

1) Формування соціальних інститутів, наприклад, державне управління, реорганізація системи вищої освіти тощо ("соцієтальний" блок);

2) Побудова регіональних суспільних структур (регіональний блок);

3) Формування місцевих громад (муніципальний блок);

4) Побудова організацій, або "організаційна інженерія" (організаційний блок);

5) Формування цільових груп і команд ("групова" інженерія). Виборчі технології та інші способи просування лідерів або їх команд $є$ складовою всіх блоків соціоінженерної діяльності [30; 35].

У процесі становлення соціальної інженерії значну роль відіграла психологія, а також прикладна антропологія, що мають справу з описом змін як у галузі людських відносин, так і в розробці принципів організаційної культури. У 1950-х рр. особливого поширення набуло застосування прикладної антропології у промисловості, яка розглядалася як своєрідна соціальна технологія (Е. Чеппл, Р. Телен, А. Кребер та інші). На думку Т. Парсонса [30], соціальна інженерія особливо успішно розвивається не в ті періоди, коли спостерігається безпосереднє застосування теоретичних принципів науки, а навпаки, коли прикладна галузь розвивається за рахунок власних теоретико-методологічних інновацій.

У 1960 р., аналізуючи логічні й методологічні проблеми, пов'язані 3 уявленням людини як компонентом системи "людина-машина", співробітники лабораторії Московського методологічного гуртка (ММГ), започаткованого Г. Щедровицьким, висунули альтернативну концепцію: цілісним об'єктом проектування має бути не технічна система чи пристрій, а система діяльності. На Заході в 1990 р. така ідея втілилась у феноменологічній методології "контекстуального проектування" (contextuallesing) [45], що змусило кардинально переглянути самі концепції 
інженерної психології й системного проектування.

Таким чином, наступним етапом у розвитку ідей управління соціальним розвитком стало проектування систем діяльності. На відміну від технічних пристроїв, системи діяльності $€$ "історичними" об'єктами, які розвиваються, відтворюються чи деградують, а тому проектування систем діяльності набуває зовсім іншого змісту й має розглядатися в контексті організації й управління. У цьому контексті проектування систем діяльності, як і проектування застосовуваних у них технічних засобів, виступає лише як момент нової організації чи реорганізації діяльності, а сам проект - не як опис продукту виробництва, а як опис того "ідеального" стану системи діяльності, якого прагнуть досягти організаційно-управлінськими заходами.

Це означає, що організація та управління - як особливі типи діяльності - мають пов'язати й узгодити штучні реорганізаційні заходи, спрямовані на досягнення "ідеального стану" системи діяльності, 3 тими процесами, які в них відбуваються, зокрема з процесами функціонування та історичних змін. Таким чином, між проектуванням, організацією й управлінням - як типами діяльності - встановлюються складні багатосторонні відношення й залежності.

Розвиток уявлень про системи діяльності відбувався у двох напрямах. Перший із них детермінував розвиток базових уявлень про системи діяльності (починаючи з 1980 р. - системи миследіяльності) [40; 42; 41; 43], насамперед про соціотехнічні системи, які пізніше назвали організаційно-технічними. Призначення проектів, програм у межах оргтехнічних систем визначається як вплив штучних, технічних засобів одних систем на інші. Другий напрям - це формування нових комплексів базових методологічних понять для аналізу розвивальних систем і таких, які мають ситуативну форму організації. Щодо останньої - це уявлення про "Три Г", які становлять систему гетерогенних (принципово різнорідних за походженням) утворень, гетерохронних (що передбачають перебіг кількох незалежних, принципово несинхронних процесів), гетерархічних (що не мають ієрархізованої організації, передбачають існування декількох незалежних ієрархій) [41]. 
Застосування інженерного підходу й наукоємних технологій до соціальних процесів окреслюється як комплексний підхід до вивчення та зміни соціальної реальності. Соціальне проектування, стратегічне планування, соціальна інноватика, психотехніка, ігрове моделювання - це лише деякі з назв, змістом яких $€$ соціоінженерна діяльність. У наші дні інтерес до соціальної інженерії починає зростати [44; 30]. I це закономірно: зі встановленням сталих правил та принципів економічних і політичних відносин зростає й потреба у фахівцях подібного рівня.

На початку XX ст. досить поширеною стала психотехніка. Термін "психотехніка" було впроваджено в науковий обіг Г. Мюнстенбергом. Цим поняттям оперував також В. Штерн. У широкому розумінні цього слова під психотехнікою розуміли будь-яку практику впливу на психіку й управління нею. У вузькому розумінні поняття "психотехніка" означало галузь психології, яка займалася впровадженням досягнень психологічної науки у виробництво й розробленням тестів на професійну придатність. Психотехніка досить активно розвивалася в 1930-1940 рр. завдяки зусиллям таких науковців як І. Шпільрейн і С.Геллерштейн. У пізніший період - 1980-1990 рр. - П. Цзен і Ю. Пахомов розглядали психотехніку як мистецтво управління психічними станами. "Суть психотехніки, переконаний В. Олешкевич, - важливо зрозуміти як структуру, яка вкорінена в європейській свідомості і яка має більш фундаментальний характер, ніж психологічна наука та прикладна психологія" [14, с. 71].

Психотехніка в широкому значенні виступає частиною культури психологічного та духовно-етичного вдосконалення людини. П̈ї елементи наявні в діяльності педагогів мистецтва, спортивних тренерів, психотерапевтів, священнослужителів. У процесі такого проектування головна увага приділяється не технічним компонентам, а людській діяльності, їі соціальним і психологічним аспектам, і його назвали соціотехнічним проектуванням. Його особливість полягає в тому, що воно відбувається без прототипів і орієнтоване на реалізацію ідеалів, які сфрормовані в теоретичній або методологічній сфрерах чи у культурі в цілому. 
Його можна охарактеризувати як особливий проектний рух, до якого залучені різноманітні типи діяльності: виробнича, соціального функціонування, експлуатаційна, традиційного проектування тощо. У ролі проектувальників почали виступати й учені: кібернетики, психологи, освітяни, соціологи. Залучені до проектного руху, вони не тільки трансформуються самі, а й суттєво модифікують проектування взагалі. Соціотехнічна діяльність орієнтована на соціальну діяльність і має своїм предметом не природу, а "соціальні утворення" (системи, в яких органічно переплітаються виробничі й культурні відносини, спільноти людей, масова діяльність та інші компоненти). Соціальні утворення виступають у вигляді стійких структур, предметного середовища, організацій, груп людей, але за всім тим розгортаються соціальні процеси і взаємодії, які утворюють "соціальне життя" [27, с. 278]. Вони мають певні закономірності розвитку, змінюються не стільки під впливом природних факторів і умов, які залежні від діяльності людей (суспільства), скільки під натиском, які частково чи повністю визначаються цілеспрямованою діяльністю людини й суспільства.

Як зазначав А.Запорожець, мислення - це діяльність, в якій суб'єкт неначе виходить за межі власної свідомості. У цьому процесі він певним чином ставиться до об'єкта, впливає на цей об'єкт і відчуває опір цього об'єкта. Мислення потребує нового досвіду, а не коректив старого [18, с. 178]. Таким чином, удосконалення діяльності старого типу не змінює ситуації, необхідно розробляти нові принципи діяльності, які полягають у співорганізації суб'єктів різноманітних галузей, забезпечують вихід за межі предметного підходу й разом з тим охоплюють діяльність різноманітних сфер; а прискорення процесів формування нових галузей діяльності, ускладнення їхніх проблем вимагає більш практичних методів уявлення про майбутнє. Ефективна діяльність, у результаті якої може з'явитися нова норма, нові ідеї та знання, відбувається через процес мислення, а засобом їх просування й упровадження виступає особливий вид теоретичної діяльності, яка називається проектуванням. Проектування виникло як автономна й надзвичайно ефективна сфера діяльності, що передбачала вирішення багатьох проблем і відкривала перспективи, тобто формувала 
новий тип інтелектуальної діяльності.

За останні роки вітчизняними та зарубіжними науковцями проведено значну кількість досліджень у галузі методології проектування [13], але й нині не існує загальноприйнятого розуміння поняття "соціального проектування". Різні автори наголошують на різноманітних аспектах цього процесу. Так, наприклад, зарубіжні автори наводять такі визначення проектування:

- проектування - це цілеспрямована діяльність з вирішення завдань (Д. Арчер); творча діяльність, яка викликає до життя дещо нове й корисне, чого раніше не існувало (Дж. Різуїк);

- прийняття рішень в умовах невизначеності з тяжкими наслідками у разі помилки (А. Азімов);

- моделювання передбачених дій до їх здійснення, яке повторюється до появи цілковитої впевненості в досягненні кінцевого результату (Букер);

- натхненний стрибок від фрактів сьогодення до можливостей майбутнього (Дж. К. Пейдж);

- здійснення досить складного акту інтуїції (Дж. К. Джонс) [47].

На діяльнісних підходах до соціального проектування наголошує Дж. К. Джонс: проектування - це процес, який започатковує зміни у штучному середовищі, таким чином, це процес, який передбачає будь-яку діяльність, крім природної еволюції $[120$, с. 22]. Зазвичай ці зміни відбуваються під впливом позитивних спонукальних мотивів, тобто кожен проектувальник намагається змінити світ на краще. Отже, за передбачуваними змінами стоять людські цінності, уявлення про "краще життя" (яке видається таким самоочевидним, що відсутня потреба рефлексії з цього приводу). Передбачувані цінності та способи їх розгортання у проект створюють проектну культуру. Діяльнісний підхід протистоїть натуралістичному як об’єктивному й предметно орієнтованому. На відміну від натуралістичного підходу, сфрормованого в межах природничих наук, діяльнісний підхід передбачає зміну об'єкта дослідження - від природних і предметних об'єктів до діяльнісних. Таким чином, підґрунтям будь-якого соціального проектування має бути загальне 
уявлення про специфічну людську діяльність як про спосіб реалізації суб'єкт-об’єктної взаємодії (О. Леонтьєв, Б. Ломов, А. Раппопорт, С. Рубінштейн, Г. Щедровицький) [21; 22; 25; 28; 29; 43].

На думку М. Вебера, проектування $€$ мисленою діяльністю, особливий ідеальний або чистий тип якої можна визначити як процес продумування того, чого ще немає, але повинно (чи не повинно) бути [7]. Вітчизняні вчені наводять такі визначення: Н. Бернштейн вбачає у проекті модель потрібного майбутнього [36, с. 281], М. Алексєєв, А. Раппопорт, В.Розін, Г.Щедровицький розглядають проектування як уявне перетворення певної первинної просторової ситуації на проектну модель середовища [1; 28; 31; 43]. Так наприклад, Г. Щедровицький під проектуванням розуміє перенесення продуктів мислення з уявної дійсності в реальність [42, с. 88; 43; 44]. М. Алексєєв визначає проектування як розроблення продуктів особливого та специфічного типу, які спрямовані в майбутнє й покликані забезпечити вже ними зумовлені наступні практичні розробки: різноманітні проекти й програми - від індивідуальних до всезагальних [1]. Існують також інші визначення проектування, в яких увага зосереджується на окремих його характеристиках. Наприклад, проектування - це:

- процес, який започатковує зміни у штучному середовищі;

- складний вид діяльності, в якому поєднуються три способи пізнання: природничі науки, мистецтво й математика;

- здатність вважати реальним те, що існує лише в уявному майбутньому, і шукати шлях утілення в життя передбачуваних об'єктів [15].

Таким чином, аналіз наведених визначень дає можливість розмежувати проектування як процес і як категорію. На початковому етапі проектування як процес розпочинається з певних розумових дій, уявної побудови складних конструкцій. I це відбувається у свідомості тих, хто здійснює цю діяльність. Спонукою до такої діяльності є стан невдоволення наявною ситуацією, отже, проект націлений на подолання проблеми та формується, відповідно до цього, як спосіб її подолання. Зважаючи на це, проектування - це обмежений у часі та просторі процес цілеспрямованих 
змін окремих елементів системи з установленими вимогами до якості результатів і специфікою організації діяльності. Категоріальне визначення проектування лежить в основі його концепцій. Основною $є$ категорія діяльності, яка констатує проектування як об'єкт вивчення. Таким чином, проект - це предметне бачення ідеї у вигляді конкретних образів. Така характеристика проектування задає й визначає можливі напрями, засоби, методи та весь план аналізу й опису процесу проектування [27, с. 164].

Необхідно зауважити, що спільною рисою у всіх наведених визначеннях $€$ те, що проектування - це специфічний спосіб мислення, у результаті якого розширюються межі "звичайного створення речей", відбувається перехід до певного планування; конкретно або опосередковано передбачається зв'язок із духом часу та сучасним соціумом. Наступною спільною особливістю у визначеннях проектування $€$ високий рівень невизначеності й непередбачуваності всього того, що властиве роботі з майбутнім. На наш погляд, головне, що об'єднує ці позиції, - те, що всі автори дотримуються діяльнісного підходу, тобто спеціально й концептуально обґрунтованої діяльності, забезпеченої конкретними технологіями. Отже, проектування відбувається в діяльнісній парадигмі та ґрунтується на природних закономірностях розвитку об'єкта, що проектується.

Відомо, що діяльнісний напрям проектування досить широко представлений науковими здобутками Г. Щедровицького, ідеї якого стали основними для учасників методологічного руху Московського методологічного гуртка (ММГ). У межах його діяльності було започатковано цикл програмних робіт, пов'язаних із перебудовою сфер діяльності: педагогіки, проектування, психології тощо. Причому учасники гуртка розгортали їх у двох принципово різних планах. По-перше, ідея діяльності задає об'єктно-онтологічний принцип виділення особливого плану аналізу соціальних структур. Діяльність розглядається як соціальна структура 3 певними закономірностями функціонування й розвитку. Аналізом цих закономірностей займається загальна теорія діяльності, у руслі якої виділяється відповідний тип ідеальних об'єктів, будуються моделі 
діяльності, виробляються теоретичні знання й уявлення про неї. По-друге, ідея діяльності визначає логічний принцип, завдяки якому розгортається логіка розумового аналізу діяльності об'єктів, що отримала назву змістовогенетичної логіки $[41 ; 42 ; 43 ; 44]$.

Паралельно із цим напрямом робота ММГ була присвячена також формулюванню системних уявлень, тому методологічний підхід ММГ було названо системно-діяльнісним, що зумовлено інтегруванням двох виділених планів теоретичної роботи: логіку розумової праці намагалися узгодити із характером аналізованих об'єктів. Цим визначається й логіка методологічного знання: воно лежить у двох площинах: з одного боку, фіксує знання про об'єкт, а з іншого - знання про ту діяльність і мислення, за умов котрих вони були отримані [43]. Варто зазначити, що в діяльнісному проектуванні проблематично однозначно визначити цілі й засоби, можна лише зафіксувати співвідношення між ними, створити процесуальність людської діяльності. У цьому полягає психологічна особливість процесу проектування- формування відкритих відносин у середовищі, де відбувається проектування, адже створюється нове середовище й нові відносини для певних груп людей або спільнот.

\section{4. Компонентна структура проектування в соціальних системах}

Як діяльність, проектування включає суб'єкт, об'єкт, мету, процес і результат діяльності. На основі зазначеного, суб'єктом проектування $\epsilon$ людина, об'єктом - соціальні системи, процеси й об'єкти, метою реконструкція чи створення об'єкта. У результаті такої послідовності ми маємо проект - те, що має бути здійснене, вироблене чи побудоване.

Різновиди тлумачення поняття "проектування" дають змогу узагальнити його в контексті суб'єкт-об'єктної взаємодії. Основними соціально-психологічними блоками проектування в соціальних системах $€$ такі:

1) миследіяльність суб'єктів проектування;

2) організаційно-процесуальний компонент; 
3) психологічний контекст проектування;

4) утворення нової форми (ідеї, знання тощо).

На рис. 5.3 відображена компонентна структура проектування в соціальних системах, у якій ми виділяємо чотири блоки.

Перший блок визначається миследіяльністю суб'єктів проектування. Цей блок виконує важливу місію у просуванні нових ідей і ратифікації нового знання. Як уже було зазначено, основним засобом проектування $€$ особлива теоретична діяльність - миследіяльність для забезпечення побудови нових знакових моделей, що дає можливість довести ефективність побудованої моделі досліджуваного об'єкта.

Л. Виготський вважав, що людина будує нові форми дій спочатку подумки й на папері, а потім працює над розумовими моделями, тобто вчений пов'язував це із застосуванням штучних засобів мислення, із соціальним розвитком поведінки, з використанням знаків [10, с. 124].

Миследіяльність побудована як певна освітня технологія, яка спирається на культурні зразки миследіяльності та дає змогу вводити учасників проектування в миследіяльнісне упорядкування на різних рівнях. А це сприяє формуванню метапредметних (універсальних) принципів роботи зі знаннями. Тоді ж в учасників проектування формуються відповідні навички, породжуються нові знання, здійснюються спроби їхнього розвитку та застосування в різних миследіяльнісних ситуаціях.

Другий блок є організаційним і передбачає здійснення творчого акту цілепокладання, опису продукту проектування, що закінчується моделюванням широкого соціокультурного контексту проекту. Тут визначається система цілей, що побудована на принципах ієрархії, а це уможливлює розробку поточного i перспективного проектів. Цілі проектування при формулюванні параметрів майбутнього образу можна подати у спрощеному вигляді за допомогою певних алгоритмів діяльності. Отже, будь-яке проектування починається з творчого акту цілепокладання. І воно, на думку Ю. Швалба, виступає як психологічна умова й первинна ланка розгортання діяльності [39, с. 29].

Цілепокладання наразі не є суто психічним процесом у традиційному 
розумінні цього поняття, воно набуває процесуальних характеристик, а не закладене такими психічними процесами як сприймання, пам'ять чи мислення.

Але воно $є$ психологічною функцією знання, яка може бути забезпечена різними психічними процесами.

Психологічною складовою процесу проектування $€$ постійний розвиток усіх учасників процесу проектування, тобто вони є його сукупними суб'єктами. Це виявляється в узгодженні прийняття цільових установок, параметрів майбутнього соціального продукту, позицій у прийнятті та корекції проектних рішень. Таким чином, цілі, крім заданих, фрормуються також і всередині процесу проектування, у такому випадку вони $\epsilon$ системотворним елементом проектування.

Організаційний компонент процесу проектування передбачає таку послідовність:

- організаційно-діяльнісне забезпечення самого процесу діяльності, яка повинна мати певний фрормалізований організаційний порядок;

- добір технологій проектування;

- визначення алгоритму проектування, завдяки якому зменшується невизначеність поведінки об'єктів і який істотно впливає на сам процес і логіку прийняття рішень, виступаючи як обмеження [11; 12; 15].

Цілі та зміст проектної діяльності визначають, з якою метою і що саме проектується (параметри продукту), а технології $€$ засобом здійснення поставлених цілей і офрормлення продукту. До них належать групи фракторів, що визначають поточну якість процесу проектування; його різноманітні засоби й прийоми; організаційні форми, в яких відбувається проектування; людські й матеріальні ресурси, що залучені для його забезпечення.

Таким чином, слід мати на увазі: а) сукупність дій, що виконуються проектувальниками, тобто діяльність самих проектувальників; б) продукт цих дій, тобто проект, розроблений проектувальниками у прагненні змінити дійсний стан об'єкта [11, с. 98]. 


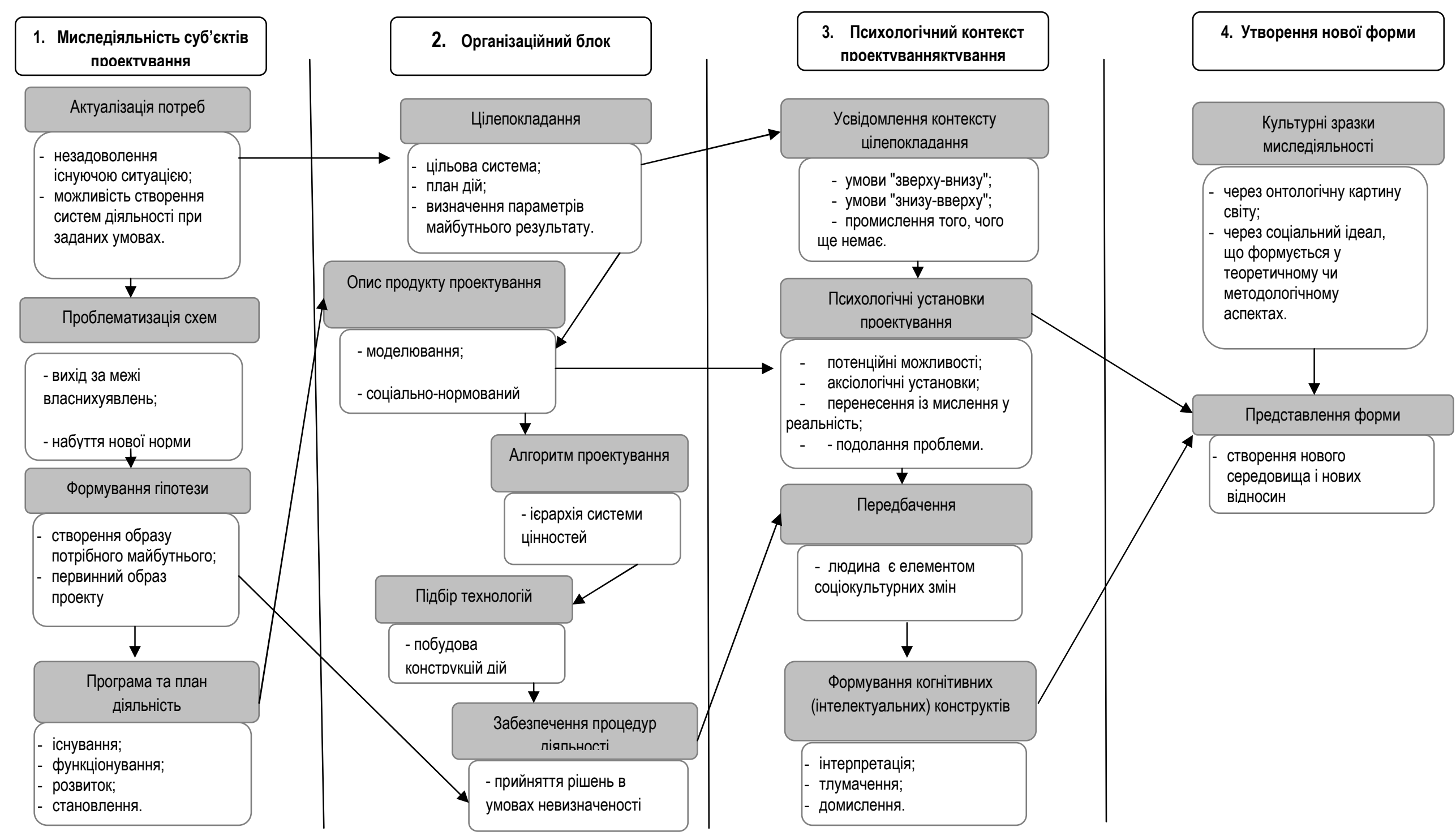

Рис. 5.3. Компонентна структура проектування у соціальних системах 
Провідним у цілепокладанні діяльності проектувальників $€$ психологічний контекст проектування, що становить третій блок проектування. На нашу думку, цьому $є$ три причини. По-перше, важливим $\epsilon$ напрям розгортання цілепокладання. Якщо програма буде запущена відповідними конструктами, створеними кимось зверху, а людина є тільки виконавцем розробленого без її участі проекту, то результати й наслідки такого проектування передбачити нескладно. Причиною невідворотного провалу подібних проектів $€$ два процеси, які запускаються програмою-документом: імітації та маніпулювання. Імітація виконання програми зумовлена, по-перше, тим, що сама програма більшістю учасників не сприймається як обов'язкова для виконання (звітувати про виконання проекту й виконати його - це не одне й те саме), по-друге, виконавець (на відміну від автора задуму) працює згідно з "буквою", а не "духом" програми.

Маніпуляція - інший процес, запуск такої "програми" здійснюється як "зверху-вниз", так і "знизу-вверх". У разі маніпуляції "зверху" необхідний супутник насильницького впровадження, маніпуляція "знизу" виступає як захисний механізм, як засіб захисту імітатора. За умов таких руйнівних змістових зв'язків цілі, що були заявлені в програмі, виявляються недосяжними. Альтернативою $є$ підхід до розробки проектів як до програми дій конкретних людей, які об'єднані у спільноту на основі загальних цінностей, бачення проблем і шляхів їх розв'язання. Об'єднання у спільноту, спільні зусилля сприяють розширенню масштабів діяльності, можливостей здійснення перетворень [16, с. 22].

У процесі продуктивної взаємодії можливий такий рівень, коли завдяки специфічним відносинам і рівню спілкування у групі проектувальників здоланою є будь-яка проблема.

По-друге, психологічний контекст компоненти проектної діяльності пов'язаний не з вирішенням конкретних завдань і проблем, а з утворенням певної нової норми, нового образу. 
Звичайно, постає необхідність відмови і навіть знецінення минулих цінностей і смислів, а це спричиняє певний виклик внутрішній сфрері особистості, на який їй треба реагувати. Здатність до адекватних реакцій на виклики пов'язана 3 акмеологічними ресурсами й потенціями людини як суб'єкта діяльності. Безумовно, це супроводжується напругою миследіяльності, переживаннями та стресами.

По-третє, формування когнітивних та інтелектуальних конструктів у процесі проектування відбувається із залученням свідомості людини. Зважаючи на те, що проектування- це насамперед образ бажаного майбутнього, який здійснюється думкою, то, як зазначає К. Поппер, у "спокусі майбутнім" нами керують очікування, скеровані нашими бажаннями й настроєм. Будь-яка інформація відбивається через структуру індивідуальної свідомості, тому наповнюється домисленням змісту. Поза переосмисленням і переконструюванням свідомістю інформація ніколи не "вливається" в мозок [26, с. 199].

Дослідженнями ментальних утворень, які контролюють і регулюють способи сприйняття, розуміння та інтерпретації людиною подій життєдіяльності, займаються представники когнітивного напряму психології, піонерами якого були Дж. Міллер та У. Найссер. Називалися ці ментальні структури по-різному: "когнітивні схеми", "конструкти", "репрезентації", - але завжди наголошувалося на такому: від характеру побудови ментальних структур залежать конкретні прояви інтелектуальної активності та, більше того, особистісні якості й характеристики соціальної поведінки людини. Такий психологічний підхід пов'язаний 3 базовими засадами когнітивної психології і стосується формулювання наукових гіпотез у термінах ментальних процесів, які не зводяться ні до тілесних реакцій організму, ні до взаємодії нервових клітин. Реалізація цього завдання зумовила необхідність повернути мислення в науки про людину. 
Четвертий блок у компонентній структурі проектування соціальних систем здійснюється із залученням культурних зразків миследіяльності, які відомі людині. Закінчується він фрормуванням соціального продукту - нової фрорми певного змісту (ідеї, знання, відносин тощо). Продуктом проектування у соціальних системах зазвичай є не реально створений об'єкт, а його "практична модель".

Важливими $€$ наслідки застосування цього продукту та відповідальність за результати. Готовність узяти відповідальність за виконання проекту й за результати його впровадження передбачає здатність проектувальників до ризиків. Соціальні системи переважно інкорпорують у собі людину, зокрема ту, яка їх проектує та реалізовує. У соціальних системах реалізація часто збігається із функціонуванням, а одним 3 його видів якраз і $\epsilon$ реалізація та відтворення системи (створення й організація, підтримка й контроль). Це є причиною того, що соціальна система та проект її реалізації ніколи не може досягнути повноти проекту, у них завжди залишаються відкриті можливості проектування й реалізації соціальних систем - це перманентний процес [28, с. 23].

Таким чином, проектування соціальних систем відбувається у вигляді роботи з ідеями, якій властиві розумова, інтелектуальна діяльність, цільове спрямування на генерацію, розроблення та комбінування ідей і рішень. Результатом цієї діяльності має стати дещо нове, в основу якого закладено сукупність розроблених, обґрунтованих і побудованих ідей - образ спроектованого продукту: нової норми, нового знання, системи.

Отже, проектування в соціальних системах - це, насамперед, інтелектуальна та практична діяльність суб'єктів по розробці та прогнозуванню на основі проектної моделі системи заходів і основних напрямів процесу. Вона має цілеспрямованість і застосування, передбачає постановку цілей, вироблення плану дій, розроблення технологій, визначення параметрів майбутніх результатів. 
Керуючись діяльнісним підходом проектування $\epsilon$ цілеспрямованою раціональною діяльністю з моделювання уявлень про майбутню діяльність, про кінцевий результат цієї діяльності та наслідки, що виникають у результаті творення й функціонування продукту цієї діяльності.

\section{5. Проектування освітнього простору особистістю (самопроектування)}

Важливою і специфічною діяльності людини є проектування освітнього простору на рівні особистості. Вона полягає у проектуванні іï внутрішнього середовища (особистісні, психологічні якості) і здійснюється переважно (або тільки) у вигляді самопроектування як передумови самовдосконалення людини (самотворення, самопобудови, самодобудови). У процесі самопроектування освітнього простору особистістю в її індивідуальній свідомості актуалізуються певні психологічні механізми. Тому на особистісному рівні проектування освітнього простору зусилля суб'єкта проектування (самої особистості) спрямовані на свій внутрішній світ, на фрормування в собі затребуваних характеристик, рис, на власний розвиток, що складає зміст психолого-педагогічного блоку. Таким чином, індивід стає власне замовником своєї освіти, їі активним споживачем, що доводить статус позиції суб'єкта самопроектування власного освітнього простору.

Власний освітній простір для особистості $€$ концептуальним механізмом її включення у світ, який складається із сукупності об'єктів, які мають освітній зміст, але його прояви людина відчуває тільки у результаті сприйняття. Зовнішні прояви такого сприйняття полягають у самовиявленні психологічних механізмів, завдяки яким людина проявляє природне бажання до самовиявлення та самоактуалізації, проявляти здатність до самоорганізації, прагнення самореалізації, як це зображено на рис. 5.4 . 


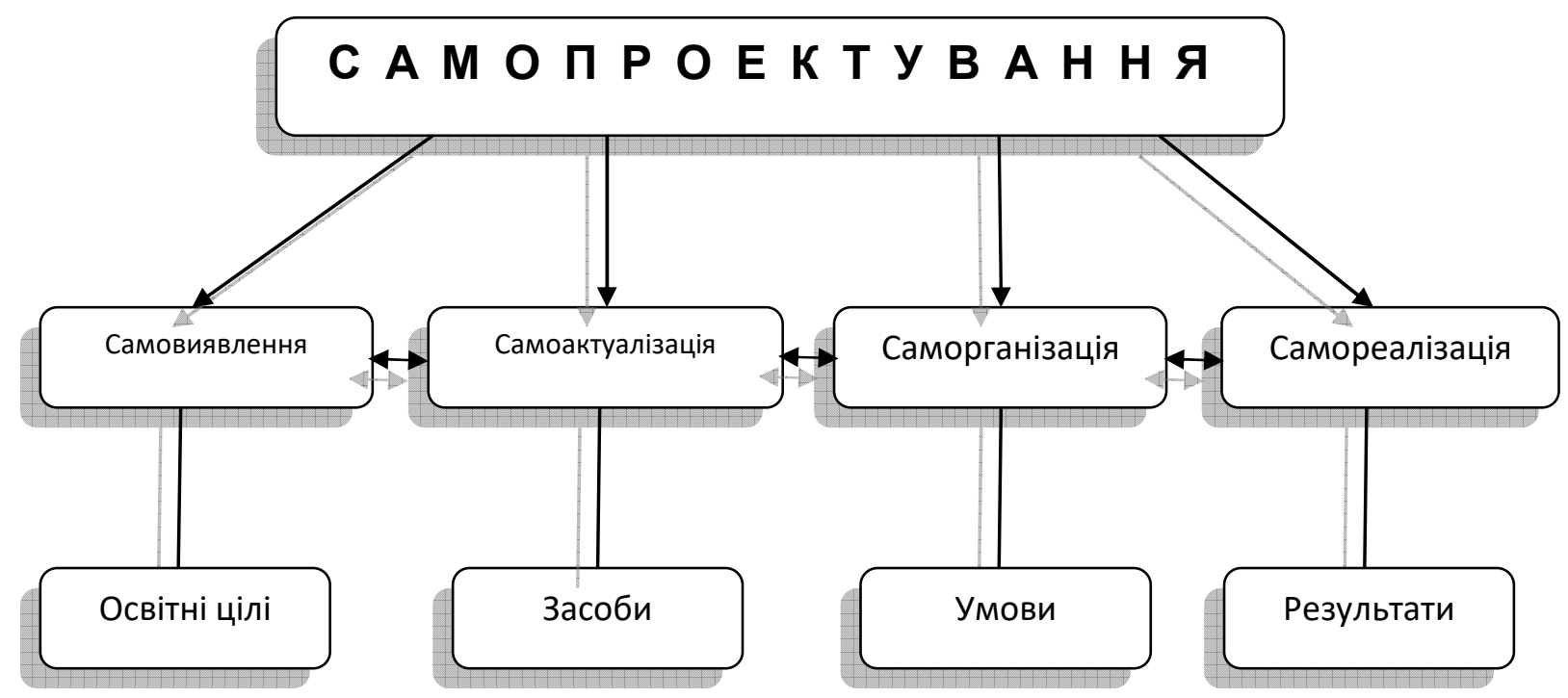

Рис. 5.4. Психологічні механізми самопроектування освітнього простору особистістю

У ході такого становлення і розвитку особистості освіта набуває просторових вимірів.

Самовиявлення - це суб'єктне відчуття, прямо пов'язане 3 очікуваннями людини на успішне вирішення проблем, внаслідок чого у неї підвищується самоповага, особистісна незалежність, впевненість у можливій самореалізації. Самопроектування освітнього простору особистості засноване на вірі в її індивідуальний досвід, на здатності до саморозкриття, умінні виявити в собі унікальну і неповторну сутність, визначені напрямі і засобів особистісного розвитку в межах можливостей освітнього простору. Самовиявлення спричиняє бажання до самоактуалізації особистістю власних індивідуальних рис, якостей, здатність до ухвалення рішень, мотиви і потреби розвитку. Здатність до самоорганізації освіти особистості залежить від її знань, вмінь, навичок, творчих здібностей, намірів дружньої взаємодії, незалежно від індивідуальних і колективних світоглядних і ментальних особливостей. Все це допомагає особистості найповніше реалізувати себе у професійній діяльності і різноманітних суспільних відносинах. Психологічним 
аспектом самореалізації особистості в освіті $€$ розробка засобів і умов, які стимулюють процеси пізнання і самопізнання, цілепокладання, проектування перспектив власної життєдіяльності за допомогою освіти. Тому в процесі самореалізації особистості актуалізується розкриття її внутрішніх ресурсів, особистісного потенціалу.

Суттєві зміни в особистості можливі насамперед у тих випадках, коли суб'єкт змушений оволодівати чимось новим вперше або долати складності у взаємодії з навколишнім світом і самим собою. У процесі самопроектування особистість несе відповідальність за реалізацію проекту першочергово перед самою собою.

Отже, у процесі проектування освітнього простору на особистісному рівні індивід як єдиний суб'єкт проектування самопроектує власний освітній простір у вигляді певної уяви про можливу освітню діяльність, її результати в досить широкому, але доступному й реальному для особистості контексті.

Як наслідок такого самопроектування особистість відчуває певною мірою особистісну належність до освітнього простору, до його окремих процесів, елементів, ситуацій. Таке відчуття $\epsilon$ складовою важливого регулятивного механізму особистості, її самоідентифікації, а процес самопроектування освітнього простору $є$ механізмом її розвитку та реалізації власної суб’єктності під час пізнання. В такому сенсі. освітня діяльність особистості може бути представлена у вигляді моделі самопроектування освітнього простору особистості (див. рис. 5.5).

Перший (верхній правий) квадрант ми визначаємо як позапрофресійно-статусна освіта із широким профрілем.

Другий (верхній лівий) квадрант відтворює формалізований рівень професійно орієнтованої освіти.

Третій (лівий нижній) квадрант визначає освіту "Профеесійна самоосвіта - рівень професіонала". 


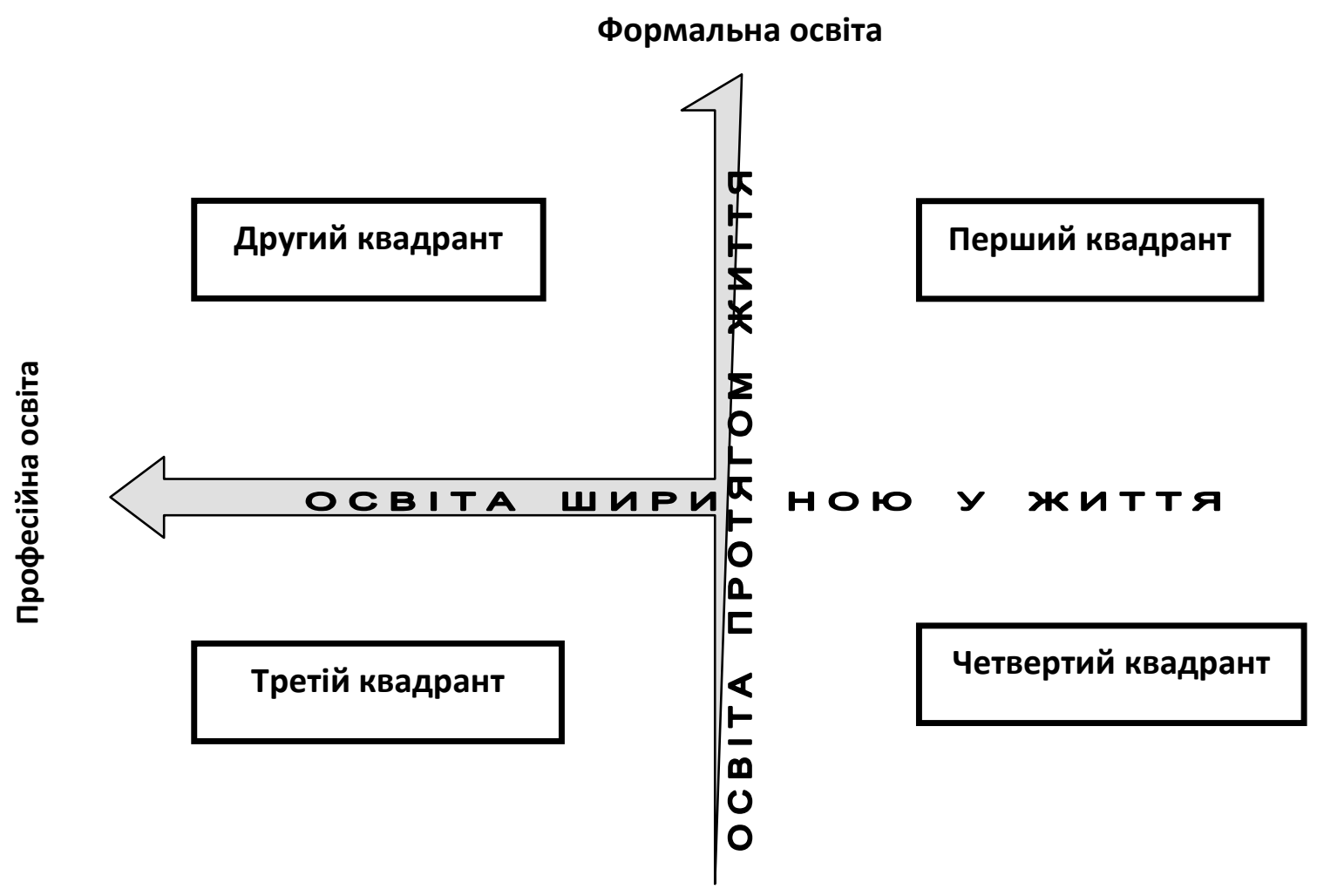

Неформальна освіта

Рис. 5.5. Модель самопроектування освітнього простору особистості

Четвертий (нижній правий) квадрант освітнього простору визначає творчий рівень особистості - "Активно-творча самоосвіта творчий рівень освіти".

Психологічний вибір особистості виявляє різноплановість у схильності до активно-творчої освіти зайнятістю.

В основі самопроектування освітнього простору лежить взаємодія людини з простором життєдіяльності, яка має системний характер, бере до уваги активність людини і містить показники її життєвих інтересів, які виступають критерієм ефективності під час проведення психологічного дослідження. Тому індивідуальнопсихологічні компоненти самопроектування зважають на певні напрями розвитку окремого індивіда. При цьому розглядаються інтелектуальні, емоційні, вольові та інші аспекти розвитку людини. 
Основою такої моделі став особистісно-освітній досвід освоєння суб'єктом певного змісту освітньої діяльності. Відповідно до цього досвіду визначається індивідуальна освітня траєкторія суб'єкта, яка насичена перетинами, рефункціоналізацією видів, форм і засобів освітньої діяльності, що корелюють із відповідними запитами суб’єкта щодо самореалізації. У результаті цього алгоритму фрормується модель певних особистісних та освітніх компетенцій, на основі яких складаються репертуари освітньої діяльності (професійної, побутової, за інтересами тощо).

Таким чином, у процесі самопроектування власного освітнього простору особистість виявляє прагнення його побудови, добудови, перебудови в тому напрямі, який їй здається найбільш доцільним, вдалим, актуальним на сьогодні або в майбутньому. Цей процес супроводжується індивідуальним розвитком на основі власного життєвого й узагальненого соціокультурного досвіду. У процесі само проектування особистість проявляє здатність до індивідуального свідомого самопроектування освітнього простору, що передбачає особистісне включення у процес цілепокладання, планування, самореалізації тощо. Для неї природною є здатність до фрормування індивідуального освітнього простору, програмування освітньої траєкторії руху в ньому, але це вимагає певної роботи над собою. Тому самопроектування освітнього простору особистості здійснюється на індивідуальних засадах і забезпечує індивідуальність освітньої траєкторії руху особистості в цьому просторі. Вона визначається залежно від спрямованості інтересів і потреб, а також рівня знань. Відповідно до цього здійснюється організація індивідуального режиму освітньої діяльності, яка узгоджується 3 концепцією розвивального та особистісно орієнтованого навчання.

Завдяки внутрішнім психологічним механізмам у особистості розвивається здатність усвідомлювати себе активним суб'єктом освітнього простору та об'єктом власних спостережень і 
перетворень. Здатність до самоаналізу передбачає оволодіння певним досвідом освітньої діяльності, який поповнюється час від часу й узагальнюється цим самим досвідом на основі внутрішніх інтенцій особистості, структурованим під впливом цілей, мотивів, намірів людини.

Отже, самопроектування освітнього простору особистості здійснюється у процесі задоволення культурних, соціальних і освітніх потреб особистості, які актуалізуються під впливом конкретної життєвої ситуації. Це здійснюється в результаті спеціально організованого процесу, до якого людина залучена через формальні/неформальні освітні структури, або спонтанного процесу 3 оволодіння знаннями, вміннями, навичками, необхідними для здійснення особистістю основних соціальних функцій, результатом чого $є$ готовність активно діяти у складних професійних, соціальних та особистісних ситуаціях. Процес такої освіти не обов'язково мусить бути безперервним, він може бути організованим і реалізованим людиною в разі нужди, яка пов'язана з виникненням освітніх потреб з метою поповнення дефріциту власної компетентності в тій чи іншій сорері життєдіяльності. У результаті реалізації освітніх проектів особистість набуває власного образу та індивідуальності. 


\section{ВИСНОВКИ}

Дослідження стану інституціональних трансформацій в економіці України дало можливість визначати основні напрями і зміст проведення необхідних ресрорм за допомогою створення нових інститутів та інституцій. Такі правили і норми фрормують прогресивне інституціональне середовище для господарського розвитку i забезпечення більш цивілізованого добробуту для людей.

Розвиток українського суспільства визначив зміни, що реалізовані через реформування відносин власності шляхом приватизації та корпоратизації, які стали каталізатором інституціональних трансформацій. Особливості інституціональної динаміки зумовлюють пошук інструментів розвитку корпоративного сектору та розробку інституціональної теорії корпорації. Завданням інституціональної теорії розвитку корпорації стає фрормування механізмів з урахуванням національних особливостей, що забезпечать ефективний соціально-економічний розвиток суспільства на основі функціонування корпоративної економіки.

Інституціональні перетворення розглядаються як процес неперервних неформальних змін, що закріпляються в фрормальній інституціональній системі суспільства у вигляді відповідних норм поведінки і створення організацій, що контролюють їх дотримання.

Аналіз розвитку корпорацій в Україні та світі дав можливість визначити перспективи корпоративної економіки з позицій зміни економічних інститутів і різноманітності їх форм.

На основі оцінки стану розвитку людського капіталу визначено основні напрями розвитку ринку праці та підготовки фахівців, в системі освіти.

Визначені інституціональні пріоритети розвитку людського капіталу в Україні з використанням досвіду інших країн та завдань, що стоять перед державою в оновленій інституціональній системі управління господарством. 
Сформовано нове уявлення про економічну безпеку підприємства, перспективи фрункціонування підприємства, виявлення загроз і суперечностей сприяють формуванню її теоретичної моделі у вигляді бажаного результату в діяльності підприємства. Результатом такого проектування стає певний проект, функціональна специфріка якого залежить від певних умов: стану середовища, в якому працює підприємство, особливостей суб'єктів господарювання, функціональних зв'язків між структурами підприємства, можливостей реалізації проекту, очікуваних результатів.

Провідною фрункціональною тенденцією освітнього простору визначено його розвиток у напрямі неперервності та всеосяжності, а його проектування зумовлене психологічними детермінантами, що супроводжують фоомування нового змісту, форм і характеру освіти. Сучасний стан освіти розглядається як процес ії перетворення у подовжену протягом усього життя сфреру діяльності людини, а здобутки людства у галузі освіти $€$ основою для формування складної соціальної структури у вигляді освітнього простору. Нові знання перетворюються у генератор розширення простору розвитку особистості, стимулюють активність ії самовизначення та самореалізації, сприяють більш успішному входженню в нові сфери творчої практики. 


\section{ЛITEPATУРА}

\section{Розділ 1}

1. Азоев Г.Л. Конкурентные преимущества фрирмы / Г.Л. Азоев, А.П. Геленков. - М. : Типография Новости, 2000. - 256 с.

2. Бакан Дж. Корпорация: патологическая погоня за прибылью / Дж. Бакан ; [пер. с англ.]. - М. : И.Д. Вильямс, 2007. - 288 с.

3. Белорус О.Г. Глобальные трансформации и стратегии развития : монографрия / [О.Г. Белорус, Д.Г. Лукьяненко и др.]. - К. : Орияне, 2000. - 424 с.

4. Веблен Т. Теория праздного класа: экономическое исследование институций / Т. Веблен ; [пер.с англ. С.Г. Сорокиной ; под общ. ред. В.В. Мотылева]. - М. : Прогресс, 1984. - 367 с.

5. Вільямсон О.Е. Логіка економічної організації / О.Е. Вільямсон // Природа фірми: Походження, еволюція і розвиток / [за ред. О.Е. Вільямсона, С.Дж. Вінтера ; пер. з англ. А.В. Куликова ; наук. ред. пер. В.М. Кузьменко]. - К. : А.С.К., 2002. - С. 122-159.

6. ВолинськийГ. Про конкурентні переваги в умовах глобалізації / Г.Волинський // Економіка України. - 2006. № 12 (541). - С. 68-72.

7. Гасанов Г. Конкурентная борьба крупной компании / Г. Гасанов // Економіка та держава. - 2008. - № 4. - С. 27-29.

8. Геєць В. Конкуренція в бізнесі і конкуренція в політиці / В. Геєць // Конкуренція. Вісник Антимонопольного комітету України. 2007. - № 1. - C. 2-5.

9. Глазьев С. Возможности и ограничения техникоекономического развития России в условиях структурных изменений в мировой экономике [Электронный ресурс] / Сергей Глазьев. Режим доступа: http://spkurdyumov.narod.ru/glaziev.htm.

10. Глазьев С.Ю. О стратегии развития российской экономики / С.Ю. Глазьев. - М. : Центральный экономико-математический 
институт РАН, 2001. - 120 с.

11. Горбатов В.М. Теоретичні основи конкурентоспроможності та розвитку інтегрованих структур бізнесу : авторефр. дис. ... д-ра екон. наук: 08.06.01 / В.М. Горбатов ; Харківський національний економічний ун-т. - Х., 2006. - 40 с.

12. Гэлбррейт Дж.К. Экономические теории и цели общества / Джон Кеннет Гэлбрейт. - М. : Прогресс, 1976. - с. 406.

13. Дафт Р.Л. Менеджмент / Р.Л. Дафт ; [пер. с англ.]. - СПб. : Питер, 2002. - 832 с.

14. ДемзетцГ. Теорія фрірми: ще один погляд / Гарольд Демзетц // Природа фрірми: Походження, еволюція і розвиток / [за ред. О.Е. Вільямсона, С.Дж. Вінтера; пер. з англ. А.В. Куликова; наук. ред. пер. В.М. Кузьменко]. - К. : А.С.К., 2002. - С. 217-242.

15. Джосков П.Л. Специфрічність активів і структура вертикальних відносин: емпіричні дані / П.Л. Джосков // Природа фірми: Походження, еволюція і розвиток / [за ред. О.Е. Вільямсона, С.Дж. Вінтера ; пер. 3 англ. А.В. Куликова; наук. ред. пер. В.М. Кузьменко]. - К. : А.С.К., 2002. - С. 160-188.

16. Економіка України в умовах глобалізації / [М.П. Денисенко, А.П. Гречан, Ю.Б. Пінчук та ін.] // Економіка та держава. - 2006. № 5 . - C. 28-31.

17. Емельянов С. Международная конкурентоспособность производителей США: методика анализа / С. Емельянов // Мировая экономика и международные отношения. - 2002. - № 3. - С. 83-90.

18. Євтушевський В.А. Стратегія корпоративного управління / В.А. Євтушевський, К.В. Ковальська, Н.В. Бутенко. - К. : Знання, 2007. - 287 c.

19. Задоя А. Базові економічні інститути в депресивній системі / А. Задоя // Інституціональні перетворення в суспільстві: світовий досвід і українська реальність : матер. II міжнар. наук.-практ. конф. I [за заг. ред. А.А. Ткача]. - Мелітополь : МІДМУ ГУ «ЗІДМУ», 2007. C. 59-63. 
20. Задоя А. Новітня економіка та проблеми євроінтеграції України / А. Задоя // Інституціональний вектор економічного розвитку : зб. наук. пр. МІДМУ «КПУ». - Вип. 1 (1). - Мелітополь : КПУ, 2008. - С. 45-56.

21. Капелюшников Р.И. Теория трансакционных издержек [Электронный ресурс] / Ростислав Исакович Капелюшников // Библиотечка Либертариума. -1998. - 23 августа. - Режим доступа: http://www.libertarium.ru/10623.

22. Капелюшников Р.И. Экономическая теория прав собственности / Р.И. Капелющников. - М. : ИМЭМО РАН, 1990. $328 \mathrm{c}$.

23. Кіндзерський Ю.

Проблеми

національної конкурентоспроможності та пріоритети конкурентної політики В Україні / Ю. Кіндзерський, Г. Паламарчук // Економіка України. - 2006. - № 8 (537). - С. 19-29.

24. Коуз Р.Г. Природа фрірми (1937) / Р.Г. Коуз // Природа фрірми: Походження, еволюція і розвиток / [за ред. О.Е. Вільямсона, С.Дж. Вінтера; пер. 3 англ. А.В. Куликова; наук. ред. пер. В.М. Кузьменко]. - К. : А.С.К., 2002. - С. 30-48.

25. Коуз Р.Г. Природа фрірми: походження, значення, вплив / Р.Г. Коуз // Природа фрірми: Походження, еволюція і розвиток / [за ред. О.Е. Вільямсона, С.Дж. Вінтера; пер. $з$ англ. А.В. Куликова; наук. ред. пер. В.М. Кузьменко]. - К. : А.С.К., 2002. - С. 49-101.

26. Кредісов В.А. Підприємництво - вирішальний фактор розвитку країн з перехідною економікою / В.А. Кредісов. - К. : Знання України, 2003. - 327 с.

27. Лакатос И. Фальсификация и методология научноисследовательских программ / М. Лакатос. - М.: Академический проект, 1995. - 423 c.

28. Лукашевич В.М. Глобалистика : учеб. пособ. / В.М. Лукашевич. - Л. : Новий Світ-2000, 2004. - 392 с.

29. Лысенко Ю.Г. Стратегия формирования инвестиционной 
привлекательности металлургических предприятий Украины: монография / [Ю.Г. Лысенко, А.П. Белый, Н.Н. Иванов и др. ; под общ. ред. проф. Ю.Г. Лысенко]. - Донецк : Юго-Восток, Лтд, 2005. 352 c.

30. Мазур И.И. Эффрективный менеджмент : учеб. пособ. для вузов / И.И. Мазур, В.Д. Шапиро, Н.Г. Ольдерогте ; [под общ. ред. И.И. Мазура]. - М. : Высшая школа, 2003. - 555 с.

31. Манохина Н.В. Институциональные структуры реальной экономики: теория развития и практика хозяйствования / Н.В. Манохина ; Сарат. гос. соц.-экон. ун-т. - Саратов, 2002. - 248 с.

32. Международный менеджмент / [под ред. С.Э. Пивоварова, Л.С. Парасевича, А.И. Майзеля]. - СПб. : Питер, 2002. - 576 с.

33. Менар К. Экономика организаций / К. Менар ; [пер. с фрр. ; под ред. А.Г. Худокормова]. - М. : Инфра-М, 1996. - 309 с.

34. Михайловська О. «Європейський парадокс» інноваційного розвитку: уроки для України / О. Михайловська // Економіка України. 2006. - № 6. - C. 80-85.

35. Мочерний С.В. Світове господарство в умовах глобалізації : монографія / С.В. Мочерний, Я.С. Ларіна, С.В. Фомішин. - К. : НікаЦентр, 2006. - 200 c.

36. Новий курс: реформи в Україні. 2010-2015. Національна доповідь / [за заг. ред. В.М. Гейця та ін.]. - К. : НВЦ НБУВ, 2010. 232 c.

37. Новицький В.Є. Міжнародна економічна діяльність України : підручник / В.Є. Новицький. - К. : КНЕУ, 2003. - 948 с.

38. Новицький В.Є. Регулятивні стратегії відкритих економічних систем і глобальна конкуренція за ресурси / В.Є. Новицький // Економіка України. - 2007. - № 7. - С. 4-14.

39. Норт Д. Институты, институциональные изменения и функционирование экономики / Д.Норт; [пер. с англ. А.Н. Нестеренко ; предисл. и науч. ред. Б.З. Мильнера]. - М. : Фонд экономической книги «НАЧАЛА», 1997. - 180 с. - (Современная 
институционально-эволюционная теория).

40. Норт Д.С. Институты и экономический рост: историческое введение / Д.С. Норт. - М. : THESIS. Весна, 1993. - Т. 1. - Вып. 2. C. 69-91.

41. Осецький В.Л. Глобалізаційні виміри інноваційності та конкурентоспроможності корпорацій / В.Л. Осецький // Slusarczyk B Krupa, K.WI. Zarzadzanie w dobie globalizacj: monografia (wybrane aspekty) TIB Bratislava. - 2008. - 415 c.

42. Осецький В.Л. Захист і розвиток інтелектуальної власності в Україні / В.Л. Осецький // Теоретичні і практичні аспекти економіки та інтелектуальної власності : зб. наук. пр. - Маріуполь : Вега-Принт, 2009. - C. 48-52.

43. Осецький В.Л. Інвестиції як інструмент інноваційного розвитку економіки [Електронний ресурс] / В.Л. Осецький // Вісник Української академії банківської справи. - 2005. - № 1 (18). - С. 3-7. - Режим доступу: http://www.lib.academy.sumy.ua/library/Visnik/Visnik_1_(18)_2005.htm\#_ Toc109100537.

44. Оскольський В. Про перспективи становлення конкурентоспроможної регіональної економіки / В. Оскольський // Економіка України. - 2007. - № 12 (553). - С. 4-11.

45. Официальный сайт Международного Валютного Фонда [Электронный ресурс]. - доступа: http://www.imf.org/external/russian/index.htm.

46. Офріційний сайт Міністерства закордонних справ України [Електронний ресурс]. - Режим доступу: http://www.mfa.gov.ua.

47. Петруня Ю.Є. Економічна політика держави: «суспільний вибір» в умовах глобалізації / Ю.Є.Петруня // Бюлетень Міжнародного Нобелівського економічного фроруму. - 2010. - № 1 (3). - T. 3. - C. 263-270.

48. Пономаренко В. Управління міжнародною конкурентоспроможністю підприємства як наукова і навчальна 
дисципліна / В. Пономаренко, Л. Піддубна // Економіка України. 2007. - № 12 (553). - С. 17-27.

49. Попова В. Інституціонально-господарські орієнтири формування ВВП / В. Попова // Економіка України. - 2006. - № 9 (538). - C. 27-33.

50. Пригожин А.И. Методы развития организаций / А.И. Пригожин. - М. : МЦФЭР, 2003. - 864 с.

51. Природа фрірми: Походження, еволюція і розвиток / [за ред. О.Е. Вільямсона, С.Дж. Вінтера; пер. з англ. А.В. Куликова; наук. ред. пер. В.М. Кузьменко]. - К. : А.С.К., 2002. - 336 с.

52. Радєва М.М. Глобальна інституціоналізація корпоративної економіки / М.М. Радєва // Інституціональна парадигма цивілізаційного розвитку : монографія : у 4 кн. / [за заг. ред. А. Ткача]. - Запоріжжя: КПУ, 2011. - Кн. 4: Інституціоналізація розвитку міжнародних економічних відносин в Україні і Польщі / [А. Ткач, О. Гугнін, Г. Осташ та ін. ; за ред. А. Ткача, Г. Осташа]. - С. 100-128.

53. Радєва М.М. Інституціональна основа інтеграційних процесів у корпоративній економіці / М.М. Радєва // Інституціональний вектор економічного розвитку : зб. наук. пр. МІДМУ “КПУ". - Мелітополь : КПУ, 2010. - Вип. 3 (1). - С. 21-30.

54. Радєва М.М. І Інформаційно-технологічна складова трансформації конкурентного середовища корпорації в умовах глобалізації / М.М. Радєва // Економіка та держава. - 2010. - № 11. C. 47-49.

55. Радєва М.М. Конкурентне середовище корпорації / М.М. Радєва // Вісник Хмельницького національного університету. Економічні науки. - 2010. - № 3. - Т. 1 (151). - С. 173-177.

56. Радєва М.М. Корпорація в глобальній економіці: протиріччя та перспективі / М.М. Радєва // Інвестиції: практика та досвід. - 2009. - № 24. - C. 28-31.

57. Радєва М.М. Системные кризисы корпоративной экономики / М.М. Радєва // Бизнес-информ. - 2010. - № 1. - С. 4-10. 
58. Реутов В.Є. Конкурентоздатність підприємства: критерії, показники і методики оцінювання / В.Є. Реутов // Економіка та держава. - 2006. - № 5. - С. 65-67.

59. Сірко А.В. Корпоративні відносини в перехідній економіці: проблеми теорії і практики / А.В. Сірко. - К. : Імекс, 2004. - 414 с.

60. Соболь В.А. Тенденции глобализации корпоративного управления / В.А. Соболь // Економіка та держава. - 2006. - № 9. С. $46-48$.

61. Столярчук Я. Новітні тенденції міжнародної монополізації капіталу / Ярослава Столярчук // Міжнародна економічна політика. 2008. - № 8-9. - С. 104-127.

62. Ткач А. Інституціоналізація економіки - синергетичний парадокс / Анатолій Ткач // Інституціональний вектор економічного розвитку : зб. наук. пр. МІДМУ «КПУ». - Мелітополь : КПУ, 2008. Вип. 2 (1). - С. 7-12.

63. Ткач А. Інституціоналізація світогосподарських пріоритетів у процесі реінтеграції України / А. Ткач // Інституціональна парадигма цивілізаційного розвитку : монографрія : у 4 кн. / [за ред. А. Ткача]. Запоріжжя : ГУ «ЗІГМУ», 2007. - Кн. 1: Інституціональні передумови соціально-економічного розвитку / [А. Ткач, В. Ільїн, Т. Ткач та ін. ]. C. $199-211$.

64. Ткач А.А. Інституціональна економіка. Нова інституціональна економічна теорія: навч. посіб. / А.А. Ткач. - К. : Центр учбової літератури, 2007. - 304 с.

65. Ткач А.А. Інституціональні основи ринкової інфрраструктури: монографрія / А.А. Ткач. - К. : Об'єднаний інститут економіки, 2005. 295 c.

66. Ткач Т.В. Психолого-педагогічний підхід до економіки знань / Т.В. Ткач // Освітній простір особистості в економіці знань: монографія / [Т.В. Ткач, В.Й. Бочелюк та ін. ; за ред. Т.В. Ткач]. Запоріжжя : КПУ, 2009. - С. 8-44.

67. Фатхутдинов Р.А. Стратегический менеджмент : учебник / 
Р.А. Фатхутдинов. - М. : Дело, 2002. - 448 с.

68. Филюк Г. Монополія, конкуренція та проблема інновацій / Г. Філюк // Конкуренція. Вісник Антимонопольного комітету України. 2007. - № 4. - C. 26-33.

69. Харт О.Д. Неповні контракти і теорія фрірми / О.Д. Харт // Природа фрірми: Походження, еволюція і розвиток / [за ред. О.Е. Вільямсона, С.Дж. Вінтера; пер. $з$ англ. А.В. Куликова; наук. ред. пер. В.М. Кузьменко]. - К. : А.С.К., 2002. - С. 189-216.

70. Ходжосон Д. Экономическая теория и институты: Манифест современной институциональной экономической теории / Д. Ходжосон ; [пер. с англ.]. - М. : Дело, 2003. - 464 с.

71. Цыренова А.А. Развитие человеческого капитала в условиях трансформации институциональной среды / А.А. Цыренова. - Улан-Удэ : Изд-во ВСГТУ, 2006. - 166 с.

72. Черговий пленум Спілки економістів України і міжнародна конференція // Економіка України. - 2007. - № 12. - С. 85-90.

73. Чувардинський О.Г. Зовнішня політика України в умовах світової економіної інтеграції й глобалізації / О.Г. Чувардинський // Економіка та держава. - 2006. - № 2. - С. 36-39.

74. Шаститко А.Е. Новая институциональная экономическая теория / А.Е. Шаститко. - [3-е изд., перераб. и доп.]. - М. : Экономический факультет МГУ, ТЕИС, 2002. - 591 с.

75. Alchian A. Production, Information Costs, and Economic Organization / A. Alchian, H. Demsetz // American Economic Review. 1972. - № 62. - P. 777-795.

76. Clark D. On Intel's Help, Reports Profit [Електронний ресурс] / Don Clark // The Wall Street Journal. - 2010. - JANUARY 22. - Режим доступу: http://online.wsj.com/article/.

77. Coase R. The Nature of the Firm / R. Coase // Economica. 1937. - P. 386-405; repr. (1952) in G. Stigler and K. Boulding, eds., Reading in Price Theory. Homewood, III.: Richard D. Irwin.

78. Coase R. The Nature of the Firm: Influence / R. Coase // 
Journal of Law, Economics and Organization. - 1988. - V. 4. - P. 33-47.

79. Demsetz H. "The Exchange and Enforcement of Property Rights" / H. Demsetz // Journal of Law, Economics, and Organization. 1967. - № 7. - P. 11-26.

80. Demsetz H. The Structure of Corporate Ownership: Causes and Consequences / H. Demsetz, K. Lehn // Journal of Political Economy. 1985. - № 93. - P. 1155-1177. Demsetz H. The Structure of Corporate Ownership: Causes and Consequences / H. Demsetz, K. Lehn // Journal of Political Economy. - 1985. - № 93. - P. 1155-1177.

81. Grossman S. The Costs and Benefits of Ownership: A Theory of Vertical and Lateral Integration / S. Grossman, O. Hart // Journal of Political Economy. - 1986. - № 94. - P. 691-719.

82. Klein B. Vertical Integration, Appropriable Rents and the Competitive Contracting Process / B. Klein, R. Crawford, A. Alchian // Journal of Law, Economics and Organization. - 1978. - № 21. - P. 2-32.

83. Macneil I.R. Reflections on Relational Contract / I.R. Macneil // Journal of Institutional and Theoretical Economics. - 1974. - № 41. P. 541-546.

84. Williamson Oliver. Markets and Hierarchies: Analyses and Antitrust Implications / O. Williamson. - New York : Free Press, 1975.

85. Winter S.G. 1982. An Essay of the Theory of Production / S.G. Winter ; [eds. S.H. Hymans] / Economics and the World around It. Ann Arbor: University of Michigan Press.

86. Winter S.G. The Research Program of the Theory of the Firm: Orthodox Critique and Evolutionary Perspective. Handbook of Behavioral Economics, v. A (Behavioral Microeconomics) / S.G. Winter; [eds. B. Gilad and S. Kaish]. - Greenwich : Conn.: JAI Press, 1986.

\section{Розділ 2}

1. Введение в институциональную экономику: Учеб. пособие / Под ред. Д.С. Львова. - М.: Экономика, 2005. 
2. Вільямсон Олівер Е. Економічні інституції капіталізму: Фірми, маркетинг, укладання контрактів. - К.: Артек, 2001.

3. Довженко М.В. Сучасна економічна теорія (Економічна нобелелогія): Навч. посіб. - К.: Видавничий центр «Академія», 2005.

4. Институциональная экономика: новая институциональная экономическая теория: Учебник / Под общей ред. д.э.н., проф. А.А. Аузана. - М.: ИНФРА-М, 2006.

5. Институциональная экономика: Учебник / Под общ.ред. А. Олейника. - М.: ИНФРА-М, 2005.

6. История экономических ученый (современный этап): Учебник / Под общ.ред. А.Г. Худокормова. - М.: ИНФРА-М, 1999.

7. Інституціональна архітектоніка і механізми економічного розвитку: Матеріали наукового симпозіуму. - Х.: ХНУ, 2005.

8. Капелюшников Р.И. Экономическая теория прав собственности. - М.: ИМЭМО, 1990.

9. Кузьминов Я.И., Юдкевич М.М. Институциональная экономика: Учеб.-метод. пособ. - М.: ГУ-ВШЭ, 2000.

10. Норт Д. Институты, институциональные изменения и функционирование экономики. - М.: Фонд экон. книги «Начала», 1997.

11. Олейник А.Н. Институциональная экономика: Учеб.пособие. - М.: ИНФРА-М, 2000.

12. Полтерович В.М. Трансплантация экономических институтов // Экономическая наука современной России. - 2001. - № 3.

13. Природа фрірми: Походження, еволюція и розвиток / Під ред. О.Е. Вільямсона, С.Дж. Вінтера; Пер. з англ. А.В. Куликова; Наук. ред. пер. В.П. Кузьменко. - К.: А. С. К., 2002.

14. Тамбовцев В.Л. Государство и экономика. - М.: Магистр, 1997.

15. Тарушкин А.Б. Институциональная экономика: Учебное пособие. - СПб.: Питер, 2004. 
16. Ткач А.А. Інституційні основи економіки в трансформаційних суспільствах // Соціально-економічні та аграрні трансформації в Україні і Польщі в контексті європейської інтеграції: Зб наук.праць / НАН України. Об'єднаний інститут економіки; Ред. кол.: В.М. Трегобчук (відп. ред.). - К., 2004.

17. Ткач А.А. Інституційні основи ринкової інфрраструктури: Монографрія / НАН України. Об'єднаний інститут економіки. - Л. - К., 2005.

18. Ткач А.А. Спецификація прав власності як базисного економічного інституту ринкової інфраструктури // Наукові праці Донецького національного технічного університету. Серія: Економічна. - Донецьк: ДОННТУ, 2004. - Вип. 75.

19. Ткач Анатолий, Осташ Гжегож. Институциональное проектирование образовательного пространства личности. Монографрия, Мелитополь-Жешув, ООО «КолорПринт», 2015.

20. Тамбовцев В.Л. Государство и экономика. - М.: Магистр, 1997. -48 c.

21. Фуруботн Э.Г., Рихтер Г. Институты и экономическая теория: Достижения новой институциональной экономической теории / Пер. с англ. под ред. В.С. Катькало, Н.П. Дроздовой. - СПб.: Издат. дом Санкт-петерб. гос. ун-та, 2005.

22. Ходжсон Джефррри. Экономическая теория и институты: Манифест современной институциональной экономической теории / Пер. с англ. - М.: Дело, 2003.

23. Шаститко А.Е. Новая институциональная экономическая теория. - М.: Экон. фрак. МГУ, ТЕИС, 2002.

24. Эггертссон Т. Экономическое поведение и институты / Пер. с англ. - М.: Дело, 2001. Якобсон Л.И. Государственный сектор экономики: экономическая теория и политика: Учебник для вузов. М.: ГУ ВШЭ, 2000.

25. Якубенко В.Д. Базисні інститути в трансформаційній економіці: Монографрія. - Л. - К.: КНЕУ, 2003. 
26. Якобсон Л.И. Государственный сектор экономики: экономическая теория и политика: Учебник для вузов. - М.: ГУ ВШЭ, 2000. - Гл. 1, 5.

27. Współczesne aspekty zarządzania. Teoria i doświadczenie. Pod red. Grzegorza Ostasza. Oficyna Wydawnicza Politechniki Rzeszowskiej, Rzeszòw, 2010.

\section{Розділ 3}

1. Аджемоглу Д. Почему одни страны богатые, а другие бедные. Происхождение власти, процветания и нищеты / Д. Аджемоглу, Дж. А. Робинсон. - М. : АСТ, 2016. - 693 с.

2. Бек У. Общество риска: на пути к другому модерну / Пер. с нем. В. Седельника, Н. Федоровой. М.: Прогресс-Традиция, 2000. $383 \mathrm{c}$.

3. Брюховецька Н.Ю. Управління розвитком людського капіталу підприємств: інституціональний аспект: монографрія / Н.Ю. Брюховецька, О.А. Чорна; НАН України, Ін-т економіка і пром-сті. Київ, 2015. - 268 с.

4. Висококваліфіковані працівники залишаться затребуваними // Праця і зарплата. - 2008. - №44 (624). - 26 листопада. - С. 3.

5. Гришнова Е.А., Азьмук Н.А., Развитие человеческого капитала и трансформация форм занятости: взаимовлияние и взаимообусловленность - Демографрія та соціальна економіка, 2014, №1(21) c. 96-85.

6. Грішнова О.А. Людський капітал: формування в системі освіти і професійної підготовки / О.А. Грішнова. - К.: Т-во «Знання», 2001. - 254 c.

7. Головкова Л. С. Розвиток трудоресурсного потенціалу залізничної галузі в контексті корпоратизації / Л.С.Головкова // Збірник наукових праць Дніпропетровського національного університету залізничного транспорту імені академіка В. Лазаряна 
«Проблеми економіки транспорту». - Дніпропетровськ, 2012. - Вип. 4. - C. 26-37.

8. Демографрічний щорічник "Населення України за 2016рік" Державна служба статистики України Демографрічний щорічник 2017 134 с. Державна служба статистики України http://www.ukrstat.gov.ua/

9. Доклад о мировом развитии 2002 года. Создание институциональных основ рыночной экономики. Всемирный банк. (Пер. с англ.). - М. : «Весь Мир», 2002. - 240 с.

10. Долан Э. Дж., Линдсей Д. Е. Рынок: микроэкономическая модель. Спб.: Автокомп. 1992 г. 496 с.

11. Долгополова И.С. Возможность исследования институциональных фракторов в рамках теории человеческого капитала // Вопросы теории и практики управления в современной экономике: Сб. науч. тр.: В 2 ч. ч.1. Теоретические аспекты управления экономикой страны и ее регионов / БГУЭП- Иркутск, 2002. Деп. в ИНИОН РАН 06.08.02, № 57388. - 0,2 п.л. С. 112-134.

12. Закон України «Про внесення змін до деяких законодавчих актів України» від 06.12.2016 №1774-VIII із змінами і доповненнями, внесеними Законом України від 3 жовтня 2017 року № 2148-VIII. [Електронний ресурc].

Режим доступу: http://search.ligazakon.ua/l_doc2.nsf/link1/T161774.html.

13. Закон України «Про оплату праці» від 24.03.1995 № 108/95BP із змінами і доповненнямивід 6 грудня 2016 року N 1774-VIII. [Електронний ресурс]. http://kodeksy.com.ua/pro_oplatu_pratsi.html.

14. Индекс инфляции. Минфин. [Електронний ресурс]. - Режим доступу: www.index.minfin.com.ua/economy/index/inflation/

15. Конституція України: прийнята на п'ятій сесії Верховної Ради України 28 червня 1996 р. № 254к/96-ВР із змінами і доповненнями [Електронний ресурс]. - Режим доступу: http://search.ligazakon.ua/__doc2.nsf/link1/ Z960254.html.

16. Корчагин Ю.А. Эффрективность и качество национальных 
человеческих капиталов стран мира [Электронный ресурс]. - Режим доступа : http://www.lerc.ru/?part=bulletin\&art=38\&page=1.

17. Людський капітал регіонів України в контексті інноваційного розвитку: моногр. / [В. П. Антонюк, О. І. Амоша, Л. Г. Мельцер та ін.]. - Донецьк: НАН України, Ін-т економіки пром-сті, 2011. - 308 с.

18. Макенова Г.У. Конкурентоспособность человеческого капитала [Текст] / Г. У. Макенова, А.К. Саурукова // Казахский национальный университет имени Аль-Фараби. Вестник КазНУ. Серия экономическая. - 2015. - №1. - С. 297 - 300.

19. Норт Даглас. Інституції, інституційна зміна та функціонувння економіки. - К.: Основи, 2000. - 189 с.

20. Олійник О. Українська трудова міграція: тенденції та очікування // Праця і зарплата. - 2008. - №15 (595). - 16 квітня. - С. 1.

21. Официальній курс НБУ. Министерство финанасов Украині 2017 https://index.minfin.com.ua/exchange/nbu/curr/usd/.

22. Поплавська Ж. Економіко-філософські аспекти людського капіталу / Ж.Поплавська, В.Поплавський // Вісник НАН України. 2002. - № 12. - C. 43-49.

23.Потенціал України та його реалізація // Праця і зарплата. 2008. - №10 (590). - 12 березня. - С. 3.

24. Промисловість України - 2016: стан та перспективи розвитку: наук.-аналіт. доп. / О.І. Амоша, І.П. Булєєв, А.І. Землянкін, Л.О. Збаразька, Ю.М. Харазішвілі та ін.; НАН України, Ін-т економіки пром-сті. - Київ, 2017. - 120 с.

25. Про стан дотримання прав людини у сорері праці // Праця і зарплата. - 2008. - № 10 (590). - 12 березня. - С. 1.

26. Радєва М.М. Инновационное развитие экономики Украины / Proceedingsof Material sof International Scientific-Practical Conference Dedicatedtothe 90 Birth Anniversary of Professor George Papava «Actual problems of economies of postcommunist countrie satcurrent stage». 28-29 June 2013. - Tbilisi: Publishinghouse of Paata Gugushvili institute 
of economics of TSU, 2013. - S. 334-337.

27. Радєва М.М. Інституційне забезпечення інвестиційного розвитку України. Інституціональний вектор економічного розвитку / Institutional Vector of Economic Development : збірник наукових праць МІДМУ “КПУ”. - Мелітополь : Вид-во КПУ, 2014. - Вип. 7 (2). - С. 2330.

28. Радєва М. М. Моделювання впливу інтелектуального капіталу на макроекономічні процеси в державі / В. М. Порохня, М. М. Радєва, В. І. Кузнецов // Держава та регіони. Серія : Економіка та підприємництво. - 2017. - № 2. - С. 22-25.

29. Реальная безработица в Украине бьет все рекорды / РИА Новости Украина. - 01.11.2016. - [Електронний ресурс]. - Режим доступу: https://rian.com.ua/analytics/20161101/1018295433.html.

30. Рекун І.І. Освітній капітал як один із найважливіших суспільних ресурсів / І.І. Рекун // Інституціональний вектор економічного розвитку / Institutional Vector of Economic Development: зб. наук. праць МІДМУ «КПУ» / редкол.: А.А. Ткач (голов. ред.) та ін. Мелітополь: Вид-во КПУ, 2012. - Вип. 5 (2). - С. 250-257.

31. Рекун І. І. Управління персоналом у системі економічної безпеки підприємства залізничного транспорту / І.І.Рекун // Економіка та держава : міжнародний науково-практичний журнал. 2015. - № 11. - C. 28-32.

32. Семикіна А.В. Людський капітал як індикатор інноваційного соціального розвитку / А.В. Семикіна // Экономика и управление. Научно-практический журнал, 2014.- № 1 - Симферополь: НАПКБ. C. $131-138$.

33. Стадний Є. Українські студенти за кордоном: фракти та стереотипи. 19 грудня $2017 . \quad$ URL: https://cedos.org.ua/uk/osvita/ukrainski-studenty-za-kordonom-fakty-tastereotypy (дата звернення: 30.01.2018).

34.Статистичний збірник «Праця України у 2016 році» / Державна служба статистики України,К:: ТОВ Видавництво «Август 
Трейд», 2017. - 234 с.

35. Статистичний щорічник України за 2016 рік. Державна служба статистики України. За ред. І.Є.Вернера, 2017. - 611 с. [Електронний ресурс]. - Режим доступу: www.ukrstat.gov.ua.

36. Сухих В.А. Методологические подходы к определению и измерению человеческого капитала в контексте социоэкономики / Сухих В.А., Блусь П.И. // Соціоекономіка. Збірник наукових праць. 2010. - С. $26-48$.

37. США: господарство, зовнішньоекономічна діяльність, регіональні особливості [Електронний ресурс]. - Режим доступу : subject.com.ua/textbook/ geography/geography10/43.html.

38. Ткач А. А. Формування інституціональної парадигми $\begin{array}{llll}\text { економічної теорії / } & \text { А. А. Ткач // Бюлетень Міжнародного }\end{array}$ Нобелівського економічного форуму. - 2013. - № 1. - С. 329-334.

39. Ткач А.А. Формування освітнього капіталу в економіці знань / А.А. Ткач, І.І. Рекун // Інституціональний вектор економічного розвитку / Institutional Vector of Economic Development: зб. наук. праць МІДМУ «КПУ» / Редкол.: А.А. Ткач (голов. ред.) та ін. - Мелітополь: Вид-во КПУ, 2012. - Вип. 5 (1). - С. 64-70.

40. Ткач А. Інституціональна економіка. Нова інституціональна економічна теорія. Навчальний посібник. - К.: Центр учбової літератури, 2007. - 304 с.

41. Ткач А. Інституоналізація економіки - синергетичний парадокс. Інституціональний вектор економічного розвитку / Institutional Vector of Economic Development: зб. наук. праць МІДМУ «КПУ» / редкол.: А.А. Ткач (голов. ред.) та ін. - Мелітополь: Вид-во КПУ, 2009. - Вип. 2. 2009. - С. 7-12.

42. Ткач Т. В. Психолого-педагогічні умови формування інституціональної моделі освітнього простору особистості / В. Коломієць, М. Радєва, А. Ткач [та ін.] // Інституціональні трансформації в економіці України : монографрія / за заг. ред. Коломієць В. М. - Мелітополь : ТОВ «Колор Принт», 2017. - 244 с. 
43. Ткач Т.В. Соціально-психологические “провалы" рыночной интеграции // Materialy Miedzynarodowej Konferencji "Wspolczesne Procesy Integracyjne w Wymiarze Spoleczno-Ekonomicznym". Rzeszow - Solina, 2003. - C. 451-454.

44. Ткач Т.В. Стимули і самомотивація особистості до неперервної освіти / Т.В. Ткач // Актуальні проблеми психології: Збірник наукових праць Інституту психології ім. Г. С. Костюка НАПН України. - К: ДП „Інформаційно-аналітичне агенство”, 2012. - Том Х. - Психологія навчання. Генетична психологія. Медична психологія. Вип. 22. - С. 714-723.

45. У Канаді планують збільшити вдвічі кількість іноземних студентів.

URL: http://zik.ua/ua/news/2014/01/16/u_kanadi_planuyut_zbilshyty_vdvichi_ kilkist_inozemnyh_studentiv_453165 (дата звернення: 31.01.2018).

46. Україна на міжнародному ринку освітніх послуг вищої освіти. URL: http://www.euroosvita.net/index.php/?category=1\&id=3758 (дата звернення: 30.01.2018).

47. Україна - 2016. Статистичний збірник. Державна служба статистики України, 2017. - 28 с. [Електронний ресурс]. - Режим доступу: www.ukrstat.gov.ua.

48. Уровень безработицы в 2017 г. / Минфин Украины. [Електронний ресурс]. - Режим доступу: http://index.minfin.com.ua.

49. Уряд захистить людей праці і підтримає роботодавців, які збережуть робочі місця // Праця і зарплата. - 2008. - №44 (624). - 26 листопада. - С. 2-3.

50. Шкурко Д. Старіння населення в Україні загрожує темпам її економічного зростання // Праця і зарплата. - 2008. - №31 (611). - 20 серпня. - С. 7.

51. Юхновський І.В. Взаємозв'язок відтворення капіталу та економічного зростання / І.В. Юхновський // Економіка - С. 127 - 134.

52. $40 \%$ діяльності українців заховано в сутінках. [Електронний ресурс]. - 
espreso.tv/article/2017/11/06/tinova_ekonomik.

53. Avey J.B. The Left Side of Psychological Capital: New Evidence on the Antecedents of Psycap / J. B. Avey // Journal of Leadership ja Organizational Studies. - 2014. - № 21 (2). - P. 141-149.

54. Becker Gary S. Human Capital. N. Y.: Columbia University Press, 1964. -380 p.

55. Bontis N., Dragonetti N., Jacobsen K., Roos G. The Knowledge Toolbox: A Review of Tools Available to Measure and Manage Intangible Resources. European Management Journa/. 1999. No. 17 (4). P. 391402.

56. Galabova L. "The five fingers of my hand": Human capital and well-being in SMEs / L. Galabova, L. McKie // Personnel Review. - 2013. - № 42 (6). - P. 662-683.

57. Czubasiewicz H. Zarządzanie zasobami ludzkimi. Warszawa: Wydawnictwo akademickie, 2000. 192 p.

58. Dobija D. Pomiar i sprawozdawczość kapitału intelektualnego przedsiębiorstwa. Warszawa: Wydawnictwo Wyższej Szkoły Przedsiębiorczości im. L. Koźmińskiego, 2003. 176 p.

59. Edvinsson L., Malone M. Kapitał intelektualny. Warszawa: Wydawnictwo Naukowe PWN, 2001. 168 p.

60. Fronczyńska M., Organizacja wiedzy -jaka czeka nas przyszłość zarządzania kapitałem ludzkim? URL: http://www.strategie.info.pl/tekst/4365.

61. Glaeser E. W. The Formation of Social Capital. OECD Conference Papers. Chicago-L, 1993. URL: www.oecd.org Reference to Education (дата звернення: 31.01.2018).

62. Goldin C. Putting the Co in Education: Timing, Reasons, and Consequences of College Coeducation from 1835 to the Present / Claudia Goldin, Lawrence F. Katz // Journal of Human Capital. University of Chicago Press, 2011. - V. 5(4). - P. 377-417.

63. Golovkova Liudmila. The institutional content of the human capital of the national economy / V. Kolomiiets, L. Golovkova // Baltic 
Journal of Economic Studies. - Riga: Publishing House "Baltija Publishing", 2017. - Vol. 3 (2017). - № 5. - P. 289-283.

64. Gregory C. The Condition of the Working Class in England, 1209-2004 / Gregory Clark // Journal of Political Economy. - 2005. - V. 113. - № 6 (December 2005). - P. 1307-1340.

65. Grossman M. On the Concept of Health Capital and Demand for Health. Journal of Political Economy. 1997. No. 2. P. 68-69.

66. Hellemans $C$. Intention to remain at work until legal retirement age: A comparative analysis among different age subgroups of employees / C. Hellemans, C. Closon // Europe's Journal of Psychology. - 2013. - 9 (3). - P. 623-639.

67. Hinkka K. Psychosocial work factors and sick leave, occupational accident, and disability pension: A cohort study of civil servants // K. Hinkka, J. Kuoppala, I. Vaananen-Tomppo, A. Lamminpaa // Journal of Occupational ja Environmental Medicine. - 2013 - 55 (2), P. 191-197.

68. Human Capital Investment, An International Comparison. OECD: Centre for Edducational Research and Innovation, 1998. 290 p.

69. Intellectual Capital Report 2000. World Bank (2000). URL: http://www.worldbank.org.

70. Juchnowicz M. Kapitał ludzki a kształtowanie przedsiębiorczości. Warszawa: Poltex, 2004. 370 p.

71. Lahelma E. Workplace bullying and common mental disorders: a follow-up study / E. Lahelma, T. Lallukka, M. Laaksonen, P. Saastamoinen, O. Rahkonen // Journal of Epidemiology Community Health. - 2012. - 66 (6). - P. 80-87.

72. Lallukka T. Workplace bullying and subsequent psychotropic medication: a cohort study with register linkage / T. Lallukka, J. Haukka, T. Partonen, O. Rahkonen, E. Lahelma // BMJ. - 2012. - Open 2 (6). - P. 12-24.

73. Lepak D. P. The human resource architecture: Toward a theory of human capital allocation and development / D. P. Lepak, S. A. Snell // 
Academy of management review. - 1999. - № 24 (1). - P. 31-48.

74. Łukasiewicz G. Kapitał Intelektualny w przedsiębiorstwie, w Kapitał Intelektualny dylematy i wyzwania. Wydawnictwo Wyższej Szkoły Biznesu w Nowy Sącz, 2001. 240 p.

75. McClelland D. Testing for Competence Rather Than for "Intelligence". American Psychologist. 1973. January. P. 1-14.

76. Mincer J. Progress in Human Capital Analysis of the Distribution of Earnings. Stanford: Junipero Serra Blvd, 1974. 67 p.

77. Nicholson J. The Living Capital of the United Kingdom. Economic Journal. 1891. No. 1. P. 95-107.

78. Newman A. Psychological capital: A review and synthesis / A. Newman, D. Ucbasaran, F. Zhu, G. Hirst // Journal of Organizational Behavior. - 2014. - № 35, (S1). - P. 120-138.

79. Paterson T. A. Thriving at work: Impact of psychological capital and supervisor support / T. A. Paterson, F. Luthans, W. Jeung // Journal of Organizational Behavior. - 2014. - № 35 (3). - P. 434-446.

80. Putnam R. Who Killed Civic America? Prospect, 1996. March. P. 66-72.

81. Ross J. Kapitał intelektualny przedsiębiorstwa. Zarządzanie na Świecie, 1997. No. 5. P 42-44.

82. Sajkiewicz A. Zasoby ludzkie w firmie. Organizacja -kierowanieekonomika. Warszawa: Poltex, 2000. 178 p.

83. Schaffer L. S. A human capital approach to career advising / L. S. Schaffer, J. M. Zalewski // NACADA Journal. - 2011. - № 31 (1). P. 75-87.

84. Schulz T. W. Investment in Human Capital. American Economic Review, 1961. March 51. P. 1-17.

85. Schultz T. Investment in Human Capital. / T. Schultz. - N. Y.: L., 1971.

86. Schutz T. W. Capital Formation by Education. Journal of Political Economy. 1960. Vol. 68. December. P. 62-77.

87. Smit A. An Inquiry into the Nature and Causes of the Wealth of 
Nations. URL: http://www2.hn.psu.edu/faculty/jmanis/ adam-smith/wealthnations.pdf (дата звернення: 30.01.2018).

88. Stoner James A. F. Vadyba / James A. F. Stoner, R. Echvard Freeman, Daniel R. Gilbert, Jr. / Jš anglụ kalbos vertè Albina Trečiokaitè / Kaunas: Poligrafija ir informatika, 1999. - 660 p.

89. Wang Z. Knowledge sharing, intellectual capital and firm performance / Z. Wang, N. Wang, H. Liang // Management Decision. 2014. - № 52 (2). - P. 230-258.

90. Wawrzyniak B. Projektowanie strategicznej polityki personalnej w przedsiębiorstwie. Warszawa: Poltex, 2001. 190 p.

91. Weizsaecker E. Come On! Capitalism, Short-termism, Population and the Destruction of the Planet / E. Weizsaecker, A. Wijkman. - Springer, 2018. - 220 p.

\section{Розділ 4}

1. Андрєєв В.ІІ. Основи інформаційної безпеки / В. І. Андрєєв, В. О. Хорошко, В. С. Чередниченко, М. Є. Шелест; за ред. проф. В. О. Хорошка. - Київ: Вид-во ДУІКТ, 2009. - 292 с

2. Базилюк А.В. Сутність інтелектуального ресурсу. Його вплив на структуру капіталу підприємства / А. В. Базилюк, Н. П. Теслюк // Вісник Національного транспортного університету. - 2011. - № 24(1). - C. $173-177$.

3. Бакаєв Л. О. Міжнародний досвід впровадження соціальної відповідальності у діяльність операторів вантажних перевезень / Л.О. Бакаєв // 3б. наук. пр. ДЕТУТ: Серія «Економіка і управління». - 2014. - Вип. 30. - С. 175-186.

4. Васильців Т. Г. Фінансово-економічна безпека підприємств України: стратегія та механізми забезпечення: монографрія / Васильців Т. Г., Волошин В. І., Бойкевич О. Р., Каркавчук В. В., [за ред. Т.Г. Васильціва]. - Львів, 2012. - 386 с. - Режим доступу: http://lv.niss.gov.ua/ content/articles/files/mono_2012-d47ce.pdf. 
5. Власюк О. С. Теорія і практика економічної безпеки в системі науки про економіку / О.С. Власюк. - Київ: Національний ін-т проблем міжнародної безпеки при РНБОУ, 2008. - 48 с.

6. Вовк О.М. Теоретичне забезпечення формування системи економічної безпеки на транспортних підприємствах / О.М. Вовк, О.В. Бричок // Проблеми підвищення ефрективності інфраструктури: зб. наук. праць. - К.: НАУ, 2013. - Вип. 38. - С. 40-46.

7. Геєць В.М. Інноваційні перспективи України: [монографрія] / В.М. Геєць, В.П. Семиноженко. - Харків: Константа, 2006. - 272 с.

8. Дикань В. Л. Техніко-економічний аналіз діяльності підприємств залізничного транспорту: підручник / В. Л. Дикань, В. В. Компанієць, І. Л. Назаренко. - Харків: УкрДАЗТ, 2013. - 547 с.

9. Дикань В. Л. Українська модель економічної системи як нова концепція розвитку національної економіки / В. Л. Дикань // Вісник економіки транспорту і промисловості: зб. наук. праць. - Харків: УкрДАЗТ, 2013. - № 44. - С. 11-17.

10. Добрынин А. И. Человеческий капитал в транзитивной экономике: фрормирование, оценка, эфффективность использования / А. И. Добрынин, С. А. Дятлов, Е. Д. Цыренова. - Санкт-Петербург: Наука, 1999. - 309 с.

11. Дэвид П. Клио и экономическая теория QWERTY II Истоки: из опыта изучения экономики как структуры и процесса / П. Дэвид. Москва: Изд. дом ГУ-ВШЭ, 2007. - С. 139-150.

12. Ейтутіс Г. Д. Теоретико-практичні основи реформування залізниць України: [монографрія] / Г.Д. Ейтутіс. - Ніжин: АспектПоліграфр, 2009. - 240 c.

13. Єщенко І. С. Сучасна економіка: [навч. посіб.] / І. С. Єщенко, Ю. І. Палкін. - Київ: Вища шк., 2005. - 327 с.

14. КоробчинськийО.Л. Методика формування систем економічної безпеки пі-дприємства / О. Л. Коробчинський // Економіка. - 2009. - № 4 (940). - С. 41-45.

15. Міщенко М. І. Проблеми розвитку залізничного транспорту 
зарубіжних країн / М. І. Міщенко //Вісник ДНУзТ. - 2009. - № 26. C. 214-222.

16. Мунтіян В.І. Економічна безпека України: монографрія / В. І. Мунтіян. - Київ: Вид-во КВІЦ, 1999. - 464 с.

17. Отенко І. П. Економічна безпека підприємства [Текст]: навч. посіб. / Отенко І. П., Іващенко Г. А., Воронков Д. К. / Харківський національний економічний університет. - Х. : ХНЕУ, 2012. - 251 с. (Укр. м.).

18. Панченко О.І. Класифрікація ризиків на залізничному транспорті як основа формування системи економічної безпеки його фрункціонування / О.І. Панченко // Збірник наукових праць ДЕТУТ. Серія «Економіка і управління». - 2012. - Вип. 19. - С. 84 - 92.

19. Петренко Е. А. Реформирование железнодорожного транспорта: теория и мировой опыт: [монография] / Е. А. Петренко; НАН Украины, Ин-т экономики пром-сти [и др.]. - Донецк: ЮгоВосток, 2010. - 413 c.

20. Політика протекціонізму як складова економічної безпеки України / І. Ф. Бінько, Я. Б. Базилюк, С. О. Коваленко; Рада нац. безпеки і оборони України. - К.: НІСД, 1997. - 78 с.

21. Природа фрірми: Походження, еволюція, розвиток / За ред. О.Е. Вільямсона, С. Дж. Вінтера; Пер з англ. А.В. Куликова; Наук. Ред. пер. В.П. Кузьменко. - К.: А.С.К., 2002. - 336 с.

22. Про схвалення Концепції забезпечення національної безпеки у фрінансовій сфері [Електронний ресурс] // Розпорядження Кабінету Міністрів України від 15.08.2012 р. № 569-р. - 2012. - Режим доступу до ресурсу: http://zakon4.rada.gov.ua/laws/show/569-2012$\% \mathrm{D} 1 \% 80$.

23. Рекун І. І. Моделювання складних економічних систем / І. І. Рекун // Інституціональний вектор економічного розвитку / Institutional Vector of Economic Development: зб. наук. праць МІДМУ «КПУ». Мелітополь: Вид-во КПУ, 2011. - Вип. 4 (2). - С. 160-164.

24. Рекун І. І. Освітній капітал як один із найважливіших 
суспільних ресурсів / І. І. Рекун // Інституціональний вектор економічного розвитку / Institutional Vector of Economic Development: зб. наук. праць МІДМУ «КПУ» / редкол.: А. А. Ткач (голов. ред.) та ін. - Мелітополь: Вид-во КПУ, 2012. - Вип. 5 (2). - С. 250-257.

25. Рекун I.І. Економічна безпека як об'єктивне явище ринкової економіки / І.І. Рекун // Науковий вісник Херсонського державного університету. Серія: Економічні науки. - Херсон: Видавничий дім «Гельветика», 2015. - Вип.12. Част.2 - С.108-112.

26. Сичов В. О.Вектори ресормування залізничної галузі України / В. О. Сичов // Локомотив-информ. - 2013. -№ 5. - С. 25-31.

27. Судакова О.І. Кількісна оцінка рівня економічної безпеки підприємства / О.І. Судакова, І.В. Криськов. - Придніпровська державна академія будівництва та архітектури, 2006. - Електронний pecypc:

http://www.rusnauka.com/

PRNIT_2006/Economics/16931.doc.htm

28. ТкачА. А., Г.Осташ. Ключевые институты экономики и новая экономическая история: монография / А. А. Ткач, Г. Осташ. Мелітополь-Rzeszów. - Колор-принт, 2014. - 212 с.

29. Флейчук М.І. Легалізація економіки та протидія корупції у системі економічної безпеки: теоретичні основи та стратегічні пріоритети в умовах глобалізації/ М.І. Флейчук. - Львів: Ахілл, 2008. $660 \mathrm{c}$.

30. Ходжсон. Д. Экономическая теория и институты: Манифест современной институциональной экономической теории / Пр с англ.. - М. :Дело, 2003. - 464 с.

31. Хусаинов Ф.И. Экономические рефрормы на железнодорожном транспорте: монография / Ф.И.Хусаинов. Москва: Наука, 2012. - 192 с.

32. Центр транспортних стратегий [Електронний ресурс]: Интернет-портал. - В польской колее: как поляки реформируют свои железные дороги. 2012. - Режим доступу: http://cfts.org.ua/articles/43036?do=print. 
33. Stachowiak Z. Teoria i praktyka mechanizmu bezpieczeństwa ekonomicznego państwa: ujęcie instytucjonalne / Akademia Obrony Narodowej.- Warszawa: Wydawnictwo Akademii Obrony Narodowej, 2012. - 406 s.

\section{Розділ 5}

1. Алексеев Н.Г. Проектирование русловий развития рефлективного мышления [Электронный ресурс]. - Режим доступа: ww.circle.ru.

2. Батюкова 3.И. Интеграция России в мировое образовательное пространство / З.И. Батюкова // Педагогика. - 1996. - № 3. - С. 98-102.

3. Белл Д. Грядущее постиндустриальное общество. Опыт соціального прогнозирования / Д. Белл. - М., 1999. - 266 с.

4. Бергер П., Лукман Т. Социальное конструирование реальности / П. Бергер, Т. Лукман // Трактат по социологии знания. М.: Медиум, 1995. -323 с.

5. Бернштейн Н.А. Физиология движений и активность / Н.А. Бернштейн; [под ред. О.Г.Газенко; Изд. подгот. И.М. Фейгенберг; АН СССР]. - М.: Наука, 1990. - 495 с.

6. Брушлинский А.В. Субъект и социальная компетентность личности / А.В. Брушлинский. - М., 1995. - 167 с.

7. Вебер М. Наука как призвание и профрессия. Самосознание европейской культуры XX века Вебер М. Избранные произведения: Пер. с нем./Сост., общ. ред. и послесл. Ю. Н. Давыдова; Предисл. П. П. Гайденко. - М.: Прогресс, 1990. —808 с.

8. Веблен Т. Теория праздного класса / Т.Веблен. - М.: Прогресс, 1984. - 367 с.

9. Веккер Л.М. Психические процессы: [в 3 т.] / Л.М. Веккер. Л.: Изд-во Ленинградского ун-та, 1981. - Т. 3. Субъективное переживание. Действие. Сознание. - 326 с. 
10. Выготский Л.С. О психологических системах: [собр. соч.] / Л.С. Выготский. - М., 1982. - С. 109-131.

11. Гаспарский В.П. Праксеологический анализ проектноконструкторских разработок [пер. с польск.] / В.П. Гаспарский. - М.: Мир, 1978. - 172 с.

12. Генисаретский О.И. Социальное проектирование как средство актуальной культурной политики / О.И. Генисаретский // Социальное проектирование в сфере культуры: методологические проблемы. - М., 1986. - С. 29-42.

13. Гильбух Ю.3. Тренировочные устройства в профессиональном обучении (психолого-педагогические аспекты) / Ю 3. Гильбух. - Киев: Вища школа, 1979. - 199с.

14. Гончаров В. С. Основы проектирования когнітивного развития школьников: [монография] / В.С. Гончаров. - Курган : Издво Курганского гос. ун-та, 2005. - 211 с.

15. Гурье Л.И. Проектирование педагогических систем: [учеб. пособие] / Л.И. Гурье. - Казань: Казан. гос. технол. ун-т, 2004. $212 \mathrm{c}$.

16. Джонс Дж.К. Методы проектирования: [пер. с англ. / 2-е изд. доп.] / Дж. К. Джонс. - М. : Мир, 1986. - 326 с.

17. Жизненный мир: [философрский словарь] / Г. Г. Кириленко, Е. В. Шевцов. - М.: Слово, 2002. - 238с.

18. Запорожец А.В. Избранные психологические труды: [в 2 т.] / А.В. Запорожец. - М.: Педагогика, 1986. - Т. 2. Развитие произвольных движений. - 296 с. .

19. Курбатов В.И. Социальное проектирование / В.И. Курбатов, О.В. Курбатов. - Ростов-на-Дону, 2001. - 416с.

20. Левин К. Определение понятия "поле в данный момент" / К. Левин // История психологии. Период открытого кризиса начала 10-х - середины 30-х годов. - М.: МГУ, 1992. - С. 190-203.

21. Леонтьев А.Н. Проблемы развития психики / А. Н. Леонтьев. - М.: Мысль, 1965. - 570 с. 
22. Ломов Б.Ф. Методологические и теоретические проблемы психологии / Б.Ф. Ломов. - М.: Прогресс, 1981. - 230 с.

23. Машбиц Е.И. Психолого-педагогические проблемы компьютеризации обучения / Е.И. Машбиц: [Педагогическая наука реформешколы]. - М.: Педагогика, 1988. - 192 с.

24. Моисеев Н.Н. Универсум. Общество. Информация / Н. Н. Моисеев. - М., 2001. - С. 345.

25. Ньютон И. Математические начала натуральной фрилософии: [цитируется по изданию “Философия естествознания] / И. Ньютон. - М.: Политиздат, 1966. - Вып. 1. - С. 152.

26. Поппер К. Эволюционная эпистемиология / К. Поппер // Эволюционная эпистемиология и логика социальных наук. Карл Поппер и его критики. - М.: Эдиториал УРСС, 2000. - С. 61.

27. Программа разработки проектирования. Концепция системного проектирования. / Отв. ред. А. А. Пископпель, В.Р. Рокитянский, Л. П. Щедровицкий. - М.: Наследие ММК, 2007. $400 \mathrm{c}$.

28. Раппопорт А. Г. Границы проектирования / А.Г. Раппопорт // Вопросы методологии. - 1991. - № 1. - С. 19.

29. Раппопорт А.Г. Проектирование без прототипов // Разработка и внедрение автоматизированных систем в проектирование (теория и методология) / А.Г. Раппопорт. - М.: Стройиздат. - 1975. - 60 c.

30. Резник Ю.М. Социальная инженерия: предметная область и границы применения / Ю.М. Резник // Социологические исследования. - 1994. - № 2. - С. 87.

31. Розин В.М. Личность как учредитель и менеджер "себя" и субъект культуры // Человек как субъект культуры / В.М. Розин. - М.: Наука, 2002. - С. 42-112.

32. Рубинштейн С. Л. Основы общей психологии / С.Л. Рубинштейн. - М.: Педагогика, 1976. - 704 с.

33. Слободчиков В. И., Исаев Е. И. Основы психологической 
антропологии. Психология развития человека: Развитие субьективной реальности в онтогенезе: Учебноепособие для вузов. М.: ШкольнаяПресса, 2000. - 416 с.

34. Социальная инженерия. Теоретико-методологические проблемы: [курс лекций] / под ред. Ю.М. Резника и В.В. Щербины. M., 1994. - 147 c.

35. Суименко Э.И. Социальная инженерия: к вопросу в научном статусе / Э.И. Суименко // Социологічна наука и образование в Украине. - Выпуск №1., - К.: МАУП., 2000. - С. 12-24.

36. Ткач А.А. Інституціональні основи ринкової інфраструктури: [монографія] / НАН України. Об'єднаний ін-т економіки / А.А. Ткач. K., 2005. - 295 c.

37. Тоффрлер Э. Создание новой цивилизации. Политика третьей волны [электронный ресурс] / Э. Тоффрлер, Х. Тоффрлер. 3a: Alvin and Heid i Toffler. Creating a New Civilization. The Politics of the Third Wave. - Atlanta, 1995. - Режим доступа: http://www.freenet.bishkek.su/jornal/n5/JRNAL511.htm.

38. Тоффрлер Э. Шок будущего / Э. Тоффрлер. [пер. с англ.] М. : ООО "Издательство АСТ", 2002. — 557 с.

39. Швалб Ю.М. Психологічні моделі аналізу соціокультурної ситуації / Ю.М. Швалб // Стратегічна панорама. - 1999. - № 1-2. [електронний pecypc]:

/Режим

доступу:

http://www.niurr.gov.ua/ukr/publishing.

40. Шукова Г.В. Г.И. Челпанов и проблема восприятия пространства / Г.В. Шукова // Психологическая наука и образование. - 2001. - № 3. - C. 99-111.

41. Щедровицкий Г.П. Избранные труды / Георгий Петрович Щедровицкий. - М., 1995. - 759 с.

42. Щедровицкий Г.П. Организация. Руководство. Управление / Г.П. Щедровицкий / Оргуправленческое мышление: идеология, методология, технология: [курс лекций / изархива Г.П. Щедровицкого]. - М.: Путь, 2000. - Т. 4. - 384 с. 
43. Щедровицкий Г.П. Принципы и общая схема методологической организации системно-структурных исследований и разработок / Г.П. Щедровицкий // Системные исследования. Методологические проблемы. Ежегодник. - М. Наука, 1981. - С. 193227.

44. Щедровицкий Г.П., Котельников С.И. Нововведения в организации / Г.П. Щедровицкий, С.И. Котельников. - М.: ВНИИСИ, 1983. -233 c.

45. Beyer H., Holtzbatt K. Contextual Design: Defining CustomerCentred Sistems. San Francisco: Morgan Kaufmann Pablishers, Inc. 1998. $-472 \mathrm{p}$.

46. Habermas, Ju. The Theory of Communication Action / Ju. Habermas. - Gambridge, 1991. - C. 215-264.

47. MINDMAP: инструмент наведения порядка в... мыслях [Electronicresource]. URL: http://meducation.com.ua/index.php? name=PagEd\&page_id=424.

48. Schutz A. The Problem of Social Reality. - The Hague: MartinusNijhoff. - 1962. 


\title{
АННОТАЦИЯ
}

\author{
Радева М., Ткач А., Коломиец В., Рекун И., Ткач Т., Золкина О.
}

\section{ТРАНСФОРМАЦИОННЫЕ ПРОЦЕССЫ В ЭКОНОМИКЕ: ИНСТИТУЦИОНАЛЬНЫЙ КОНТЕКСТ}

\begin{abstract}
Исследуются пути рефрормирования национальной экономики с использованием научного наследия представителей классического институционализма и его развития современными исследователями. Для научного анализа и практического решения основных задач трансформационных экономик рассматриваются возможности создания институциональных моделей, адаптированных к специфрике каждой страны, с учетом исторических, культурных, этнических, геополитических mрадиций.

Представлены результаты анализа трансформации базовых элементов институциональных систем национальных экономик, включающие: механизмы институциональных изменений в экономике, развития экономики, институт человеческого капитала, экономическую безопасность, институциональные модели образовательного пространства.

Ключевые слова: трансфомация экономики, институциональные изменения, человеческий капитал, экономическая безопасность, образовательное пространство личности
\end{abstract}




\section{SUMMARY}

Radeva M., Tkach A., Kolomiiets V., Rekun I., Tkach T., Zolkina O.

\section{TRANSFORMATION PROCESSES IN THE ECONOMY: INSTITUTIONAL CONTEXT}

Transformation processes in the economy of Ukrain are studied through the prism of the institutional theoretical approach, which is one of the main methodological paradigms for analyzing the strategy of reforming economic systems.

The ways of reforming the national economy using the scientific heritage of the representatives of classical institutionalism and its development by modern researchers are explored. For the scientific analysis and practical solution of the main tasks of transformational economies, the possibilities of creating institutional models adapted to the specifics of each country, taking into account historical, cultural, ethnic, geopolitical traditions are considered.

The results of the analysis of the transformation of the basic elements of the institutional systems of national economies, including: the mechanisms of institutional changes in the economy, economic development, the institution of human capital, economic security, institutional models of the educational space are presented.

Key words: economic transformation, institutional changes, human capital, economic security, educational personal space 


\section{АНОТАЦІЯ}

Радєєа М., Ткач А., Коломієць В., Рекун І., Ткач Т., Золкіна О.

\section{ТРАНСФОРМАЦІЙНІ ПРОЦЕСИ В ЕКОНОМІЦІ: ІНСТИТУЦІОНАЛЬНИЙ КОНТЕКСТ}

Досліджуються трансформаційні процеси в економіці України через призму інституційного теоретичного підходу, який є однією з основних методологічних парадигм аналізу стратегії реформування економічних систем.

Досліджуються шляхи реформування національної економіки з використанням наукової спадщини представників класичного інституціоналізму та його розвитку сучасними дослідниками. Для наукового аналізу та практичного вирішення основних завдань трансформаційних економік розалядаються можливості створення інституціональних моделей, адаптованих до специфіки кожної країни, 3 урахуванням історичних, культурних, етнічних, геополітичних традицій.

Представлені результати аналізу трансформації базових елементів інституційних систем національних економік, що включають: механізми інституційних змін в економіці, розвитку економіки, інститут людського капіталу, економічну безпеку, інституційні моделі освітнього простору.

Ключові слова: трансфомація економіки, інституціональні зміни, людський капітал, економічна безпека, освітній простір ocoбucmocmi 


\section{ІМЕННИЙ ВКАЗІВНИК}

Алчіан А.45, 49, 63,74

Беккер Г. 75,197

Бромлі Д. 8

Бьюкенен Дж. 95

Веблен Т.38, 76

Вільямсон О.76

Вінтер С. 9

Вожняк М.Г. 69

Гамільтон Д.66

Гелбрейт Дж. 51

Гриценко А. 54

Девіс Л. 34,139

Демзсец X. 60, 107

Джейскенс 204

Джосков Я. 8

Ерроу Д. 86

Задоя А. 3, 309

Ільїн В. 309

Калабрезі Г. 8, 260, 265-267

Капелюшніков Р. 9

Клейн Б. 8

Коммонс Дж. 8, 47-49, 66

Коуз Г. 5, 8 , 9, 28, 42, 48, 49,

$54,55,58,61,62,81,85$

Кузьмінов Я. 9

Лакатос И. 44

Маркс К. 67

Менар К. 9

Менгер К. 8

Найт Дж. 224

Нельсон Г. 9, 66, 170

Норт Д. 24,36,44,54, 76, 155,

Нурєєв Р. 9, 74,

Олійник А. 38

Осташ Г. 69,

Oppope K. 204

Пейович С. 8, 28, 104

Петруня Ю. 3 ,

Познер Р. 28, 61,

Полтерович В. 75

Радева М. 9, 10

Ріхтер Г. 9, 63, 76

Саймон Г. 8, 43, 71

Самуэльсон П. 51,53

Смірнов А. 103
Сміт А. 68

Скрепанті Е. 52

Сперанський 111

Стіглер Дж. 123,

Таллок Г. 61

Тамбовцев В. 79

Тевенко Л. 70

Ткач А., 74, 102, 131,

Ткач Т. 10, 190,

Фавро О. 70,72

Фуруботн Э. 8, 9, 41, 63, 74, 76

Хайек Ф. 75

Худіев К. 103

Чухно А.

Шастітко А. 9, 79

Шмоллер Г. 142

Шумпетер И. 8, 66,

Егертсон Т. 9, 104 
Марина Радєва, Анатолій Ткач, Вікторія Коломієць Іван Рекун, ТамараТкач, Ольга Золкіна

\title{
ТРАНСФОРМАЦІЙНІ ПРОЦЕСИ В ЕКОНОМІЦІ: ІНСТИТУЦІОНАЛЬНИЙ КОНТЕКСТ
}

\author{
МОНОГРАФІЯ \\ Наукове видання \\ DOI: https://doi.org/10.32901/978-966-2489-64-4/2018
}

Видавник і виробник ТОВ "Колор Принт"

72312, Запорізька обл., м. Мелітополь, вул. Університетська, 44/7

Тел. +38 (0619) 46-50-20

Свідоцтво Державного комітету з телебачення і радіомовлення

України про внесення суб'єкта

видавничої справи до Державного реєстру видавників і виробників видавничої продукції Серія ДК № 3782 від 12.05.2010 р.

Підписано до друку 28.06.2018. Формат 60×84 / 16 .

Бумага офрсетна. Печать ризографрічна. Гарнітура Arial.

Умов.-друк. аркушів 22,75.

Тираж 500 екз. Зам. № 36 від 26.07.2018 р.

ТОВ «Колор Принт»

72312, Запорізька обл., м. Мелітополь, вул. Університетська, 44/7.

Тел. +38 (0619) 46-50-20 
